\title{
Synthesis of Benzylic Alcohols by C-H Oxidation
}

Lalita Tanwar, ${ }^{\ddagger}$ Jonas Börgel, ${ }^{\ddagger}$ and Tobias Ritter*

Max-Planck-Institut für Kohlenforschung

Kaiser-Wilhelm-Platz 1, D-45470 Mülheim an der Ruhr, Germany

*E-mail: ritter@mpi-muelheim.mpg.de 


\section{TABLE OF CONTENTS}

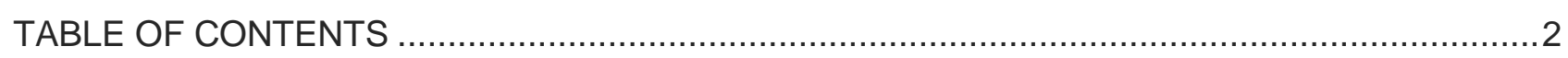

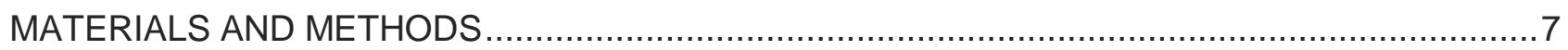

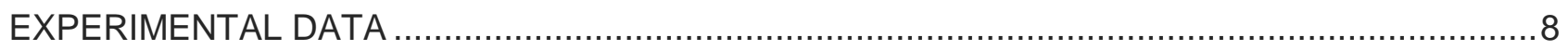

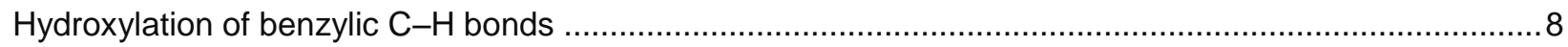

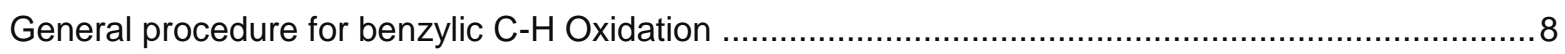

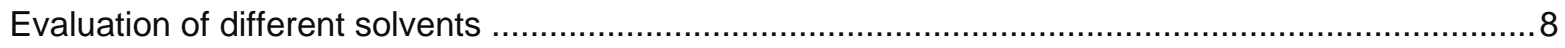

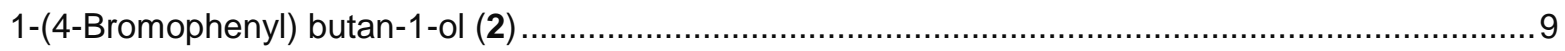

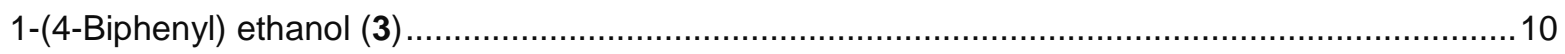

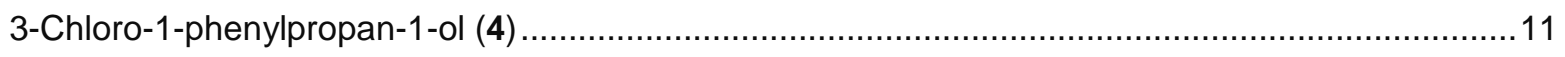

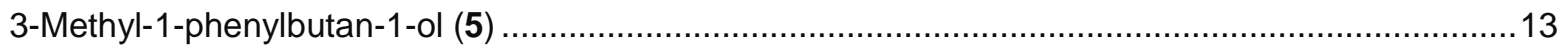

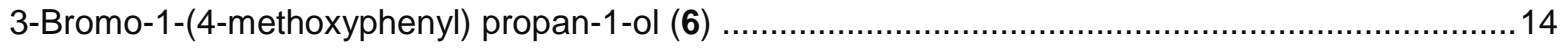

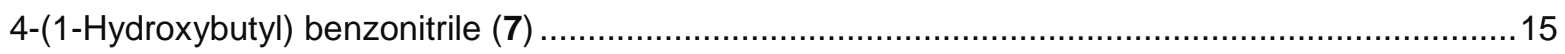

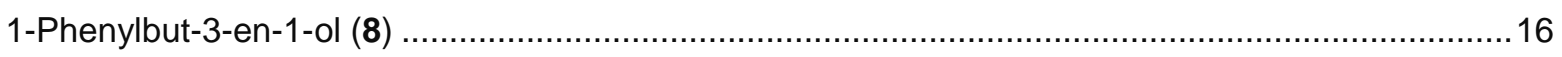

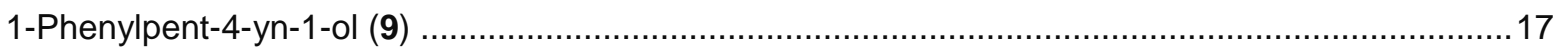

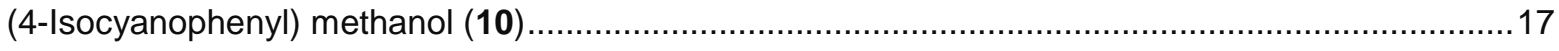

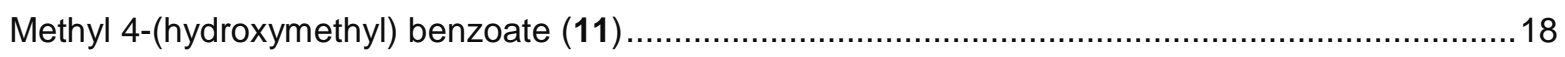

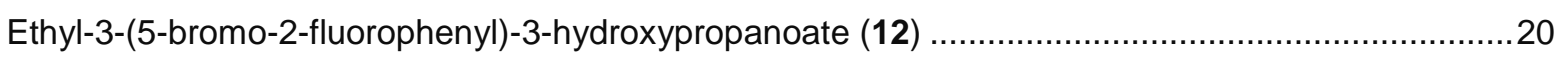

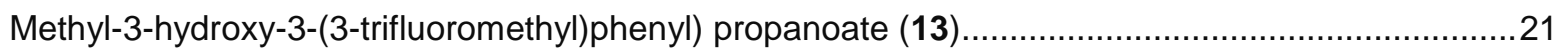

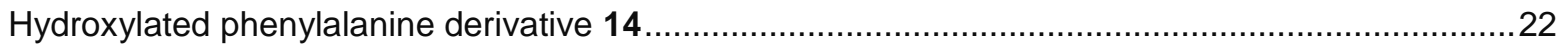

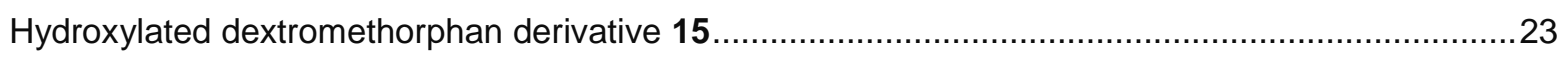

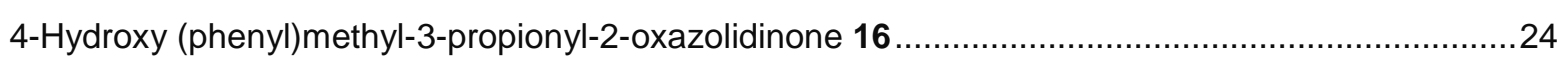

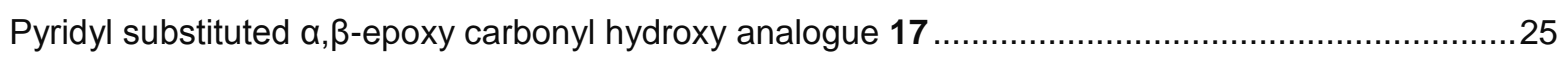

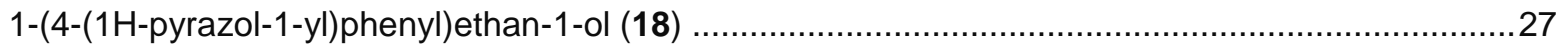

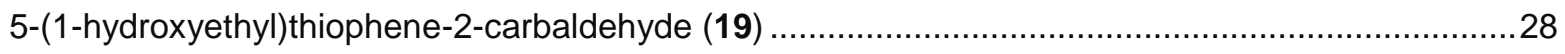

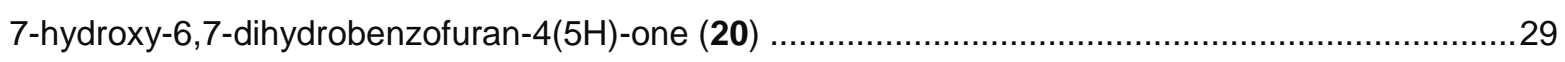

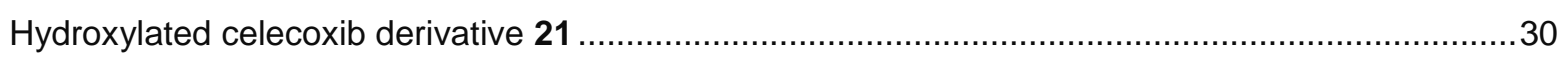

4,4 -Difluorobenzhydrol (S20A) and 4,4'-difluorbenzophenone (S20B) ........................................ 31

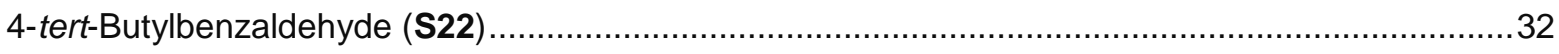

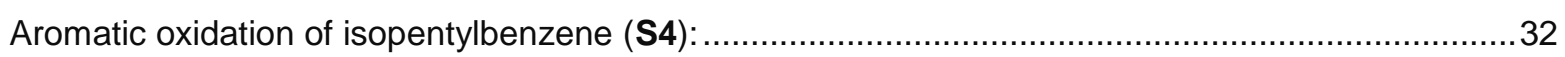

Comparison of spectra of final products and benzylic mesylates or acetates. ......................................33

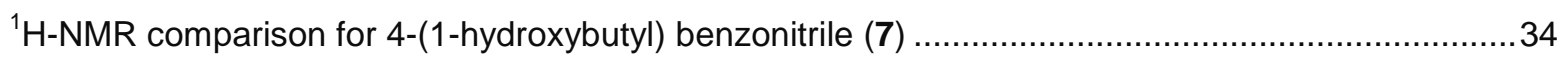

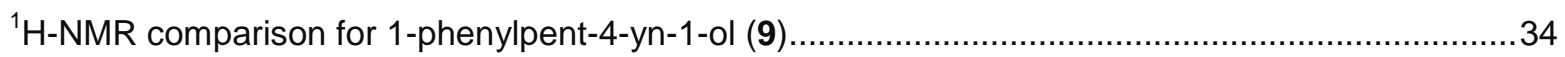

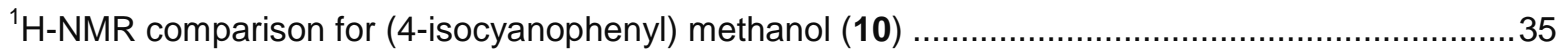

${ }^{1} \mathrm{H}-\mathrm{NMR}$ comparison for methyl-3-hydroxy-3-(3-trifluoromethyl)phenyl) propanoate.(13) ..................35 
${ }^{1} \mathrm{H}-\mathrm{NMR}$ comparison for hydroxylated phenylalanine derivative 14

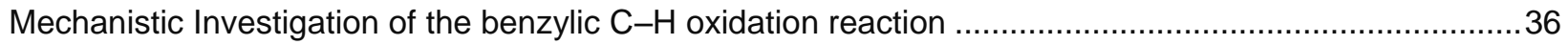

Consumption studies of TMSOAc and bis(methanesulfonyl) peroxide in dichloromethane ...............36

Consumption studies of bis(methanesulfonyl) peroxide in dichloromethane ...................................39

Replacement of TMSOAc by 2,6-di-tert-butyl pyridine .................................................................. 41

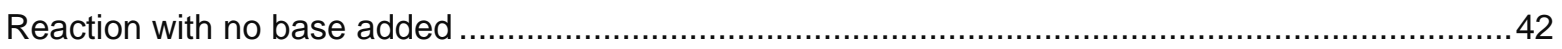

Reaction Monitoring: conversion of benzylic mesylate to benzylic acetate and styrene over time.....43

Addition of ethanesulfonic acid to the standard reaction mixture.................................................. 45

Intermolecular kinetic isotope effect (KIE) experiment ............................................................... 47

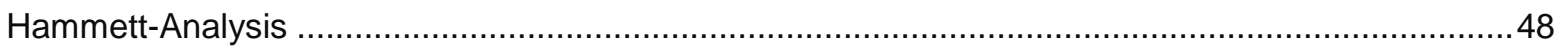

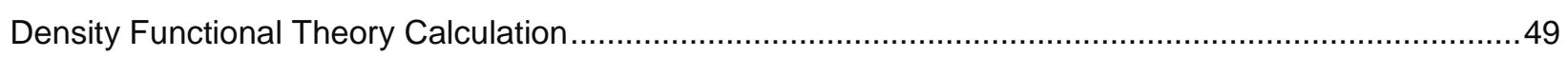

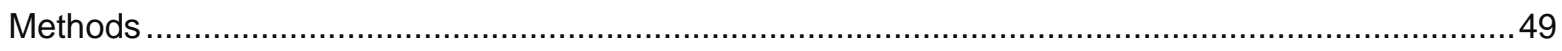

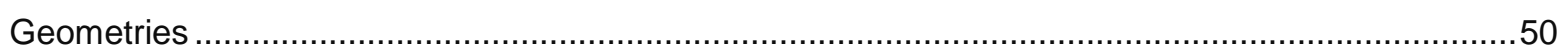

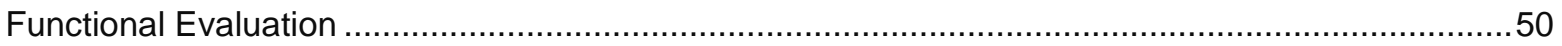

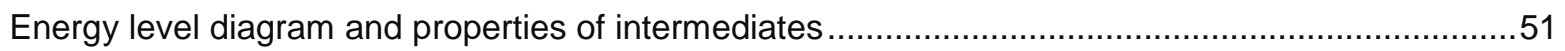

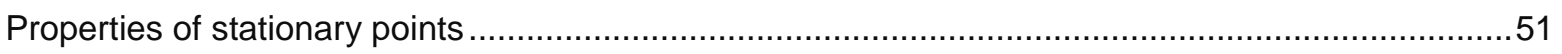

Cartesian Coordinates of optimized geometries of stationary points ...........................................54

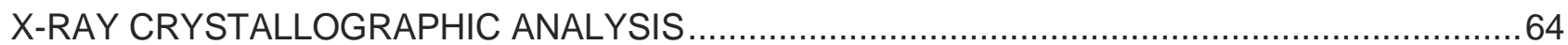

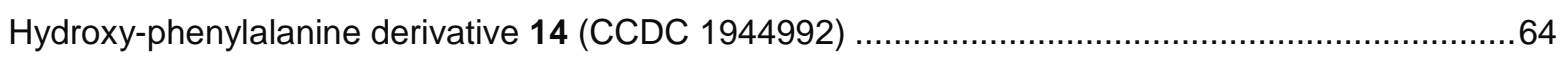

4-Hydroxy (phenyl)methyl-3-propionyl-2-oxazolidinone 16A (CCDC 1956799) ...............................67

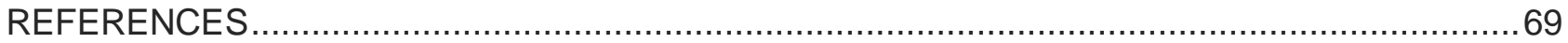

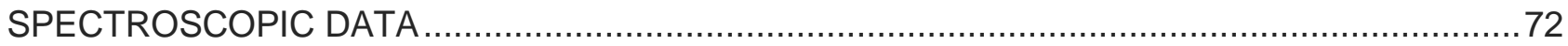

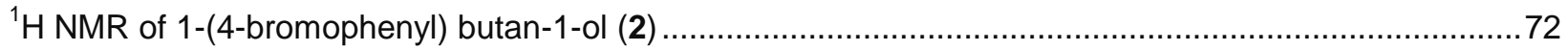

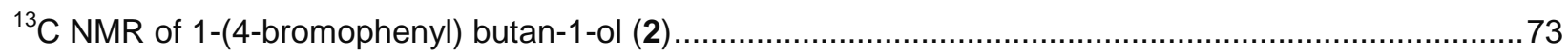

${ }^{1} \mathrm{H}$ NMR of reaction after step 1 of acylated 1-(4-biphenyl) ethanol (3A) ............................................... 74

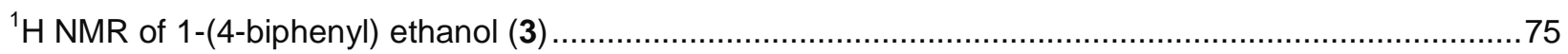

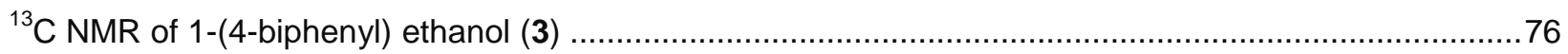

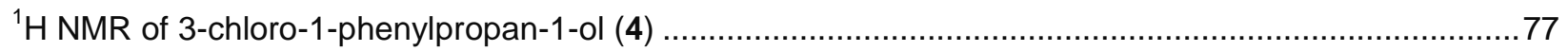

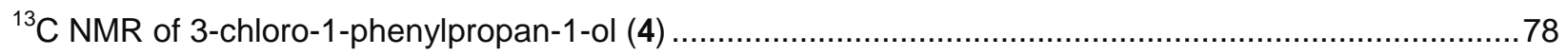

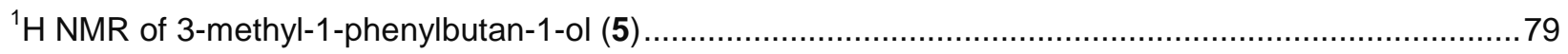

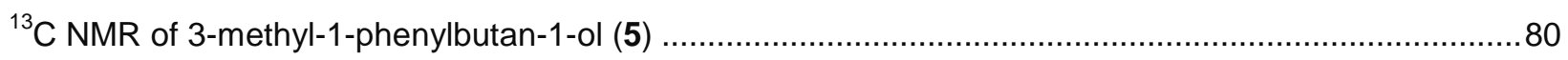

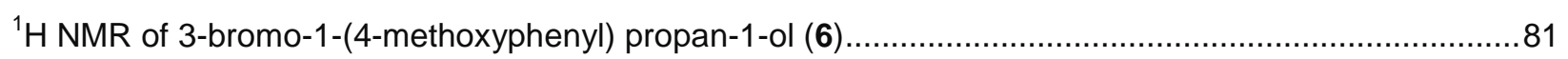


${ }^{13} \mathrm{C}$ NMR of 3-bromo-1-(4-methoxyphenyl) propan-1-ol (6)

${ }^{1} \mathrm{H}$ NMR of 4-(1-hydroxybutyl) benzonitrile (7)

${ }^{13} \mathrm{C}$ NMR of 4-(1-hydroxybutyl) benzonitrile (7)....

${ }^{1} \mathrm{H}$ NMR of 1-phenylbut-3-en-1-ol (8) .85

${ }^{13} \mathrm{C}$ NMR of 1-phenylbut-3-en-1-ol (8) .86

${ }^{1} \mathrm{H}$ NMR of 1-phenylpent-4-yn-1-ol (9)...... .87

${ }^{13} \mathrm{C}$ NMR of 1-phenylpent-4-yn-1-ol (9) ... 88

${ }^{1} \mathrm{H}$ NMR of (4-isocyanophenyl) methanol (10) .89

${ }^{13} \mathrm{C}$ NMR of (4-isocyanophenyl) methanol (10) .90

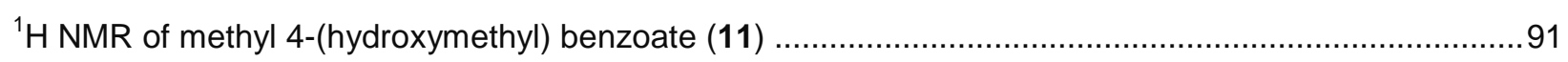

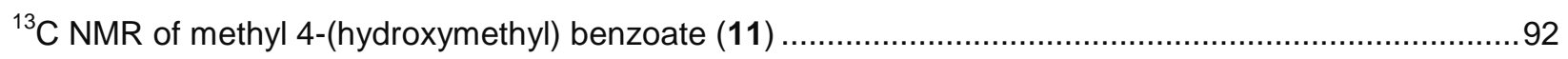

${ }^{1} \mathrm{H}$ NMR of ethyl-3-(5-bromo-2-fluorophenyl)-3-hydroxypropanoate (12) ...........................................93

${ }^{13} \mathrm{C}$ NMR of ethyl-3-(5-bromo-2-fluorophenyl)-3-hydroxypropanoate (12) ….........................................94

${ }^{19}$ F NMR of ethyl-3-(5-bromo-2-fluorophenyl)-3-hydroxypropanoate (12) ..........................................95

${ }^{1} \mathrm{H}$ NMR of mthyl-3-hydroxy-3-(3-trifluoromethyl)phenyl) propanoate.(13) ...........................................96

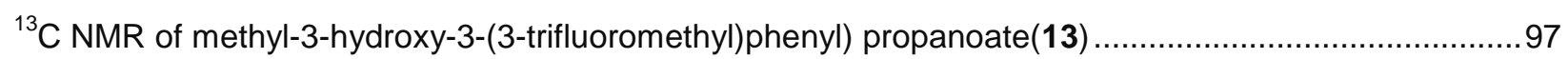

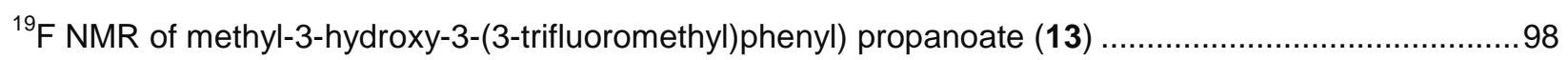

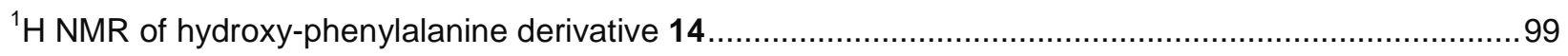

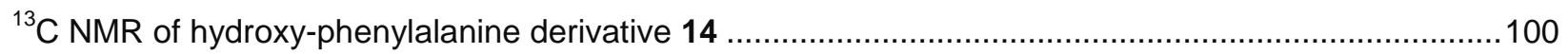

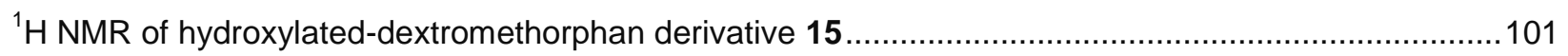

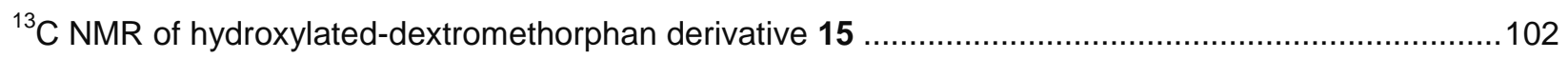

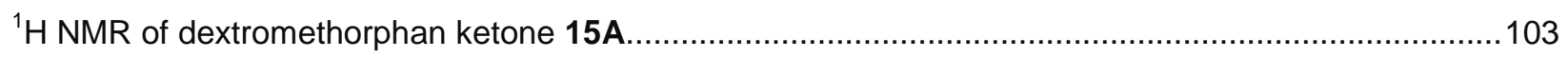

$\mathrm{H}-\mathrm{H}$ COSY spectrum of hydroxylated-dextromethorphan derivative 15 ...............................................104

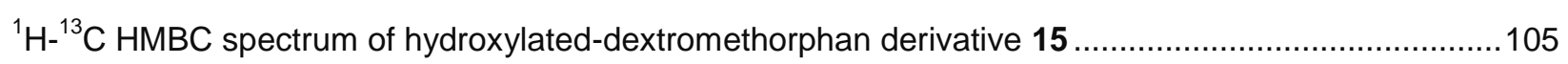

DEPT-ed-HSQC spectrum of hydroxylated-dextromethorphan derivative 15 ....................................106

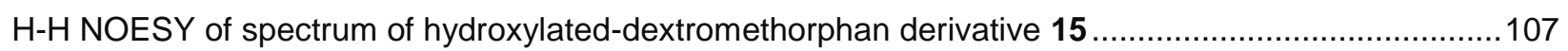

${ }^{1} \mathrm{H}$ NMR of $1^{\text {st }}$ step of 4-mesyloxy (phenyl)methyl-3-propionyl-2-oxazolidinone $\mathbf{S 3 7} \ldots \ldots \ldots \ldots \ldots \ldots \ldots \ldots \ldots . . . . . . . . . . . . .108$

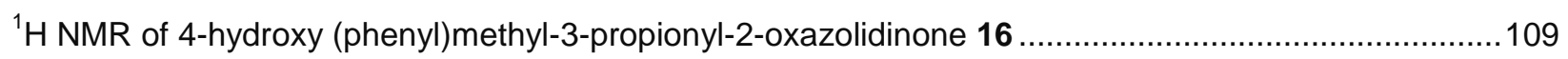

${ }^{13} \mathrm{C}$ NMR of 4-hydroxy (phenyl)methyl-3-propionyl-2-oxazolidinone 16 ............................................110 
${ }^{1} \mathrm{H}$ NMR of Benzoate derivative of 4-hydroxy (phenyl)methyl-3-propionyl-2-oxazolidinone 16A. 111

${ }^{1} \mathrm{H}$ NMR of pyridyl substituted $\alpha, \beta$-epoxy carbonyl hydroxy analogue 17A . 112

${ }^{13} \mathrm{C}$ NMR of pyridyl substituted $\alpha, \beta$-epoxy carbonyl hydroxy analogue 17A . 112

2-D NOESY spectrum of pyridyl substituted $\alpha, \beta$-epoxy carbonyl hydroxy analogue 17A 114

2-D HSQC spectrum of pyridyl substituted $\alpha, \beta$-epoxy carbonyl hydroxy analogue 17A 115

2-D HMBC spectrum of pyridyl substituted $\alpha, \beta$-epoxy carbonyl hydroxy analogue 17A 116

${ }^{1} \mathrm{H}$ NMR of pyridyl substituted $\alpha, \beta$-epoxy carbonyl hydroxy analogue 17B 117

${ }^{13} \mathrm{C}$ NMR of pyridyl substituted $\alpha, \beta$-epoxy carbonyl hydroxy analogue 17B 118

2-D NOESY spectrum of pyridyl substituted $\alpha, \beta$-epoxy carbonyl hydroxy analogue 17B 119

2-D HSQC spectrum of pyridyl substituted $\alpha, \beta$-epoxy carbonyl hydroxy analogue 17B 120

2-D HMBC spectrum of pyridyl substituted $\alpha, \beta$-epoxy carbonyl hydroxy analogue 17B 121

${ }^{1} \mathrm{H}$ NMR of 1-(4-(1H-pyrazol-1-yl)phenyl)ethan-1-ol (18) 122

${ }^{13} \mathrm{C}$ NMR of 1-(4-(1H-pyrazol-1-yl)phenyl)ethan-1-ol (18). 123

${ }^{1} \mathrm{H}$ NMR of 7-hydroxy-6,7-dihydrobenzofuran-4(5H)-one (19) ... 124

${ }^{13} \mathrm{C}$ NMR of 7-hydroxy-6,7-dihydrobenzofuran-4(5H)-one (19) 125

${ }^{1}$ H NMR of 5-(1-hydroxyethyl)thiophene-2-carbaldehyde (20) 126

${ }^{13} \mathrm{C}$ NMR of 5-(1-hydroxyethyl)thiophene-2-carbaldehyde (20) . 127

${ }^{1} \mathrm{H}$ NMR of Hydroxylated celecoxib derivative 21 128

${ }^{13} \mathrm{C}$ NMR of Hydroxylated celecoxib derivative 21 129

${ }^{19} \mathrm{~F}$ NMR of Hydroxylated celecoxib derivative $\mathbf{2 1}$. 130

${ }^{1} \mathrm{H}$ NMR of $4,4{ }^{`}$-difluorobenzhydrol (S20A).... 131

${ }^{13} \mathrm{C}$ NMR of $4,4^{-}$-difluorobenzhydrol (S20A)........ 132

${ }^{19} \mathrm{~F} \mathrm{NMR}$ of 4,4 -difluorobenzhydrol (S20A) 133

${ }^{1} \mathrm{H}$ NMR of 4,4 -difluorbenzophenone (S20B) .... 134

${ }^{13} \mathrm{C}$ NMR of 4,4 '-difluorbenzophenone (S20B) ... 135

${ }^{19} \mathrm{~F}$ NMR of 4,4 '-difluorbenzophenone (S20B) 136

${ }^{1} \mathrm{H}$ NMR of 4-tert-butylbenzaldehyde (S22). 137

${ }^{13} \mathrm{C}$ NMR of 4-tert-butylbenzaldehyde (S22) 138

${ }^{1} \mathrm{H}$ NMR of 1-(4-bromophenyl) butane-1,2-dimesoxyl (S29) 139 


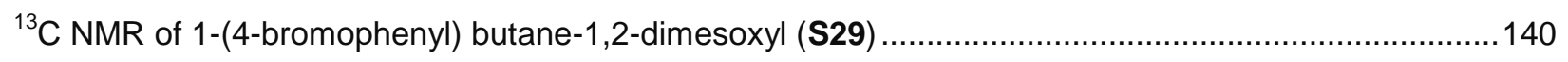




\section{MATERIALS AND METHODS}

All reactions were carried out under ambient atmosphere unless otherwise stated. High-resolution mass spectra were obtained using $Q$ Exactive Plus from Thermo. Concentration under reduced pressure was performed by rotary evaporation at $23-40^{\circ} \mathrm{C}$ at an appropriate pressure. Purified compounds were further dried under vacuum $\left(10^{-6}-10^{-3}\right.$ bar). Yields refer to purified and spectroscopically pure compounds. All airand moisture-sensitive manipulations were performed using standard Schlenk and glove-box techniques under an atmosphere of argon or nitrogen. ${ }^{1}$

\section{Solvents}

Anhydrous dichloromethane was obtained from Phoenix Solvent Drying Systems. All deuterated solvents were purchased from Euriso-Top.

\section{Chromatography}

Thin layer chromatography (TLC) was performed using EMD TLC silica gel $60 \mathrm{~F}_{254}$ plates pre-coated with $250 \mu \mathrm{m}$ thickness silica gel $60 \mathrm{~F}_{254}$ and visualized by fluorescence quenching under UV light, Cerric ammonium molybdate (CAM), and $\mathrm{KMnO}_{4}$ stain. Flash column chromatography was performed using silica gel (40-63 $\mu \mathrm{m}$ particle size) purchased from Geduran unless otherwise noted.

\section{Spectroscopy and Instruments}

NMR spectra were recorded on a Bruker Ascend ${ }^{T M} 500$ spectrometer operating at $500 \mathrm{MHz}, 471 \mathrm{MHz}$, and $126 \mathrm{MHz}$, for ${ }^{1} \mathrm{H},{ }^{19} \mathrm{~F}$, and ${ }^{13} \mathrm{C}$ acquisitions, respectively. Chemical shifts are reported in ppm with the solvent residual peak as the internal standard. For ${ }^{1} \mathrm{H} N M R: \mathrm{CDCl}_{3}, \delta 7.26 ;\left(\mathrm{CD}_{3}\right)_{2} \mathrm{SO}, \delta 2.50 ; \mathrm{CD}_{3} \mathrm{CN}, \delta 1.94, \mathrm{CD}_{2} \mathrm{Cl}_{2}$, $\delta$ 5.32. For ${ }^{13} \mathrm{C} N M R: \mathrm{CDCl}_{3}, \delta 77.16$; $\left(\mathrm{CD}_{3}\right)_{2} \mathrm{SO}, \delta 39.52 ; \mathrm{CD}_{3} \mathrm{CN}, \delta 1.32, \mathrm{CD}_{2} \mathrm{Cl}_{2}, \delta 53.84 .{ }^{2}{ }^{19} \mathrm{~F} \mathrm{NMR}$ spectra were referenced using a unified chemical shift scale based on the ${ }^{1} \mathrm{H}$ resonance of tetramethylsilane $(1 \%$ $(\mathrm{v} / \mathrm{v})$ solution in the respective solvent). ${ }^{3}$ Data is reported as follows: $\mathrm{s}=$ singlet, $\mathrm{d}=$ doublet, $\mathrm{t}=$ triplet, $\mathrm{q}=$ quartet, $\mathrm{m}=$ multiplet, $\mathrm{br}=$ broad; coupling constants in $\mathrm{Hz}$; integration.

\section{Starting materials}

All substrates and materials were used as received from commercial suppliers, unless otherwise stated. Liquid substrates were dried over powdered $3 \mathrm{~A}^{\circ}$ molecular sieves while solids were dried under high vacuum for $12 \mathrm{~h}$ before bringing inside the glovebox. TMSOAc was distilled over $3 \mathrm{~A}^{\circ}$ molecular sieves before bringing it inside the glovebox. Bis(methanesulfonyl)peroxide (1) was synthesized according to a previously reported procedure. ${ }^{4}$ 


\title{
EXPERIMENTAL DATA
}

\section{Hydroxylation of benzylic $\mathrm{C}-\mathrm{H}$ bonds}

\section{General procedure for benzylic C-H Oxidation}

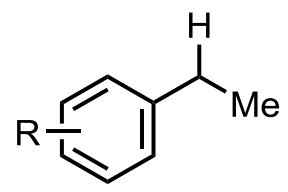

\author{
1. CuOAc (20 mol\%) \\ TMSOAC (3 equiv) \\ MsOOMs ( 1.5 equiv) \\ $\operatorname{DCM}(0.2 \mathrm{M}), 12 \mathrm{~h}, 23^{\circ} \mathrm{C}$ \\ 2. HFIP: $\mathrm{H}_{2} \mathrm{O}(0.2 \mathrm{M})$ \\ $6 \mathrm{~h}, 23^{\circ} \mathrm{C}$
}<smiles></smiles>

Under an atmosphere of argon, a flame-dried $10 \mathrm{~mL}$ Schlenk flask was charged with a Teflon-coated magnetic stirring bar, CuOAc (12.2 mg, $0.100 \mathrm{mmol}, 20.0 \mathrm{~mol} \%$ ), and arene (86.5 $\mu \mathrm{L}, 0.500 \mathrm{mmol}$, 1.00 equiv). DCM (2.5 mL, c = $0.20 \mathrm{M})$, TMSOAc $(225 \mu \mathrm{L}, 198 \mathrm{mg}, 1.50 \mathrm{mmol}, 3.00$ equiv), and solid bis(methanesulfonyl) peroxide (143 $\mathrm{mg}, 0.750 \mathrm{mmol}, 1.50$ equiv) were added at $23^{\circ} \mathrm{C}$. The reaction mixture was stirred at $23^{\circ} \mathrm{C}$ for $12 \mathrm{~h}$. Aqueous sodium sulfite solution (10\% (w:w), $1 \mathrm{~mL}$ ) was added to the reaction mixture. The resulting mixture was transferred to a separation funnel and extracted with EtOAc $(3 \times 20 \mathrm{~mL})$. The combined organic layers were washed with brine $(10 \mathrm{~mL})$, dried over $\mathrm{Na}_{2} \mathrm{SO}_{4}$, and concentrated under reduced pressure. To the residue was added HFIP: $\mathrm{H}_{2} \mathrm{O}(1: 1(\mathrm{v}: \mathrm{v}), 2.5 \mathrm{~mL}, \mathrm{C}=0.2 \mathrm{M})$. The reaction mixture was stirred for $6 \mathrm{~h}$ at $23^{\circ} \mathrm{C}$. The reaction mixture was diluted with $\mathrm{H}_{2} \mathrm{O}(5 \mathrm{~mL})$ and EtOAc $(10 \mathrm{~mL})$, and the resulting mixture was transferred to a separation funnel. The layers were separated, and the aqueous layer was extracted with EtOAc $(2 \times 10 \mathrm{~mL})$. The combined organic layers were washed with brine $(10 \mathrm{~mL})$, dried over $\mathrm{Na}_{2} \mathrm{SO}_{4}$, and concentrated under reduced pressure. The residue was purified by column chromatography on silica gel.

\section{Evaluation of different solvents}

\section{General Procedure for optimization of reaction conditions:}

In an $\mathrm{N}_{2}$-filled glovebox, to a $4 \mathrm{~mL}$ vial containing a Teflon-coated magnetic stirring bar, and 1-bromo-4butylbenzene (S1) (17.8 $\mu \mathrm{L}, 21.3 \mathrm{mg}, 0.100 \mathrm{mmol}, 1.00$ equiv) were added solvent ( $0.5 \mathrm{~mL}, \mathrm{C}=0.2 \mathrm{M}), 2,6$ di-tert-butylpyridine (33.4 $\mu \mathrm{L}, 28.7 \mathrm{mg}, 0.150 \mathrm{mmol}, 1.50$ equiv), and solid bis(methanesulfonyl) peroxide (28.5 mg, $0.150 \mathrm{mmol}, 1.50$ equiv) at $23^{\circ} \mathrm{C}$. The vial was closed with a Teflon-lined screw cap and removed from the glovebox. The reaction mixture was stirred at $23^{\circ} \mathrm{C}$ for 30 minutes. The resulting mixture was diluted with DCM (3 $\mathrm{mL})$, and passed through a silica-plug. The solvent was evaporated under reduced pressure. To the residue was added $\mathrm{CH}_{3} \mathrm{NO}_{2}(5.4 \mu \mathrm{L}, 6.1 \mathrm{mg}, 0.10 \mathrm{mmol})$ as an internal standard. The ${ }^{1} \mathrm{H}-\mathrm{NMR}$ resonance of the benzylic proton of the product $\mathbf{S} 29(\delta=5.45 \mathrm{ppm})$ was integrated relative to the ${ }^{1} \mathrm{H}$-NMR resonance of the methyl group of nitromethane $(\delta=4.30 \mathrm{ppm})$. 
Table S1: Evaluation of the reaction solvent.

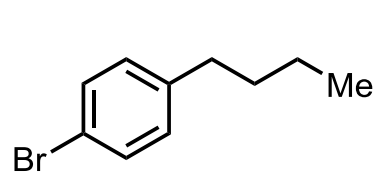

s1

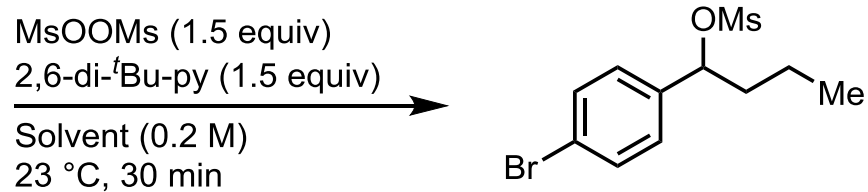

S29

\begin{tabular}{c|c|c} 
Entry & Solvent & Yield(\%) \\
\hline 1 & DCM & $80 \%$ \\
2 & HFIP & $0 \%{ }^{*}$ \\
3 & $\mathrm{MeCN}$ & $48 \%$ \\
4 & $\mathrm{MeOH}$ & $0 \%{ }^{*}$ \\
5 & $\mathrm{DCE}$ & $46 \%$ \\
6 & benzene & $35 \%$ \\
7 & hexafluorobenzene & $53 \%$
\end{tabular}

* unidentified product(s)

1-(4-Bromophenyl) butan-1-ol (2)

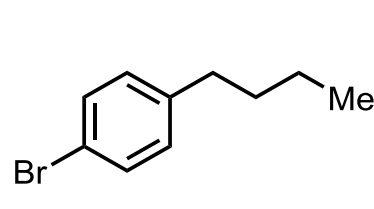

s1
1. MsOOMs ( 1.5 equiv)

2,6-di- ${ }^{-}$Bu-py (1.5 equiv)

$\operatorname{DCM}(0.2 \mathrm{M}), 30 \mathrm{~min}, 23^{\circ} \mathrm{C}$

2. HFIP: $\mathrm{H}_{2} \mathrm{O}(0.2 \mathrm{M})$

$7 \mathrm{~h}, 23^{\circ} \mathrm{C}$

$78 \%$<smiles>CCCC(O)c1ccc(Br)cc1</smiles>

2

In an $\mathrm{N}_{2}$-filled glovebox, to a $4 \mathrm{~mL}$ vial containing a Teflon-coated magnetic stirring bar, and 1-bromo-4butylbenzene (S1) $(35.4 \mu \mathrm{L}, 42.6 \mathrm{mg}, 0.200 \mathrm{mmol}, 1.00$ equiv) were added DCM (1 mL, C = 0.2 M), 2,6-ditert-butylpyridine $(67.4 \mu \mathrm{L}, 57.4 \mathrm{mg}, 0.300 \mathrm{mmol}, 1.50$ equiv), and solid bis(methanesulfonyl) peroxide ( $57.0 \mathrm{mg}, 0.300 \mathrm{mmol}, 1.50$ equiv) at $23^{\circ} \mathrm{C}$. The vial was closed with a Teflon-lined screw cap and removed from the glovebox. The reaction mixture was stirred at $23^{\circ} \mathrm{C}$ for 30 minutes. Aqueous sodium sulfite solution $(10 \%(w: w), 1 \mathrm{~mL})$ was added to the reaction mixture. The resulting mixture was transferred to a separation funnel and extracted with EtOAc $(3 \times 20 \mathrm{~mL})$. The combined organic layers were washed with brine $(10 \mathrm{~mL})$, dried over $\mathrm{Na}_{2} \mathrm{SO}_{4}$, and concentrated under reduced pressure. To the residue was added HFIP: $\mathrm{H}_{2} \mathrm{O}(1: 1$ (v:v), $1 \mathrm{~mL}, \mathrm{c}=0.2 \mathrm{M}$ ). The reaction mixture was stirred for $7 \mathrm{~h}$ at $23{ }^{\circ} \mathrm{C}$. The reaction mixture was concentrated under reduced pressure. The obtained residue was purified by column chromatography on silica gel eluting with a solvent mixture of ethyl acetate:hexanes $(20: 80(\mathrm{v}: \mathrm{v}))$ to afford $36 \mathrm{mg}$ of 2 as a 
colorless liquid $(78 \%$ yield).

$\mathbf{R}_{\boldsymbol{f}}$ (ethyl acetate:hexanes, 20:80 (v:v)) $=0.45\left(\mathrm{UV}, \mathrm{KMnO}_{4}\right)$.

\section{NMR Spectroscopy:}

${ }^{1}$ H NMR (500 MHz, $\left.\mathrm{CDCl}_{3}, 25^{\circ} \mathrm{C}, \delta\right): 7.48-7.45(\mathrm{~m}, 2 \mathrm{H}), 7.23-7.20(\mathrm{~m}, 2 \mathrm{H}), 4.65(\mathrm{dd}, J=7.5,5.8 \mathrm{~Hz}, 1 \mathrm{H})$, 1.87 (bs, $1 \mathrm{H}), 1.79-1.72(\mathrm{~m}, J=13.1,10.1,7.5,5.3 \mathrm{~Hz}, 1 \mathrm{H}), 1.67-1.60(\mathrm{~m}, J=13.6,10.0,5.8 \mathrm{~Hz}, 1 \mathrm{H}), 1.44-$ $1.35(\mathrm{~m}, 1 \mathrm{H}), 1.34-1.23(\mathrm{~m}, 1 \mathrm{H}), 0.92(\mathrm{t}, J=7.4 \mathrm{~Hz}, 3 \mathrm{H})$

${ }^{13} \mathrm{C}\left\{{ }^{1} \mathrm{H}\right\}$ NMR $\left(126 \mathrm{MHz}, \mathrm{CDCl}_{3}, 25^{\circ} \mathrm{C}, \delta\right): 144.0,131.6,127.8,121.3,73.9,41.4,19.0,14.0$.

HRMS-EI(m/z) calc'd for $\mathrm{C}_{10} \mathrm{H}_{13} \mathrm{BrO}\left[\mathrm{M}^{+}, 228.01435\right.$; found, 228.01444; deviation: +0.40 ppm.

${ }^{1} \mathrm{H}$ NMR of the reaction mixture after step 1 and aqueous work-up with $\mathrm{CH}_{3} \mathrm{NO}_{2}$ as internal standard:

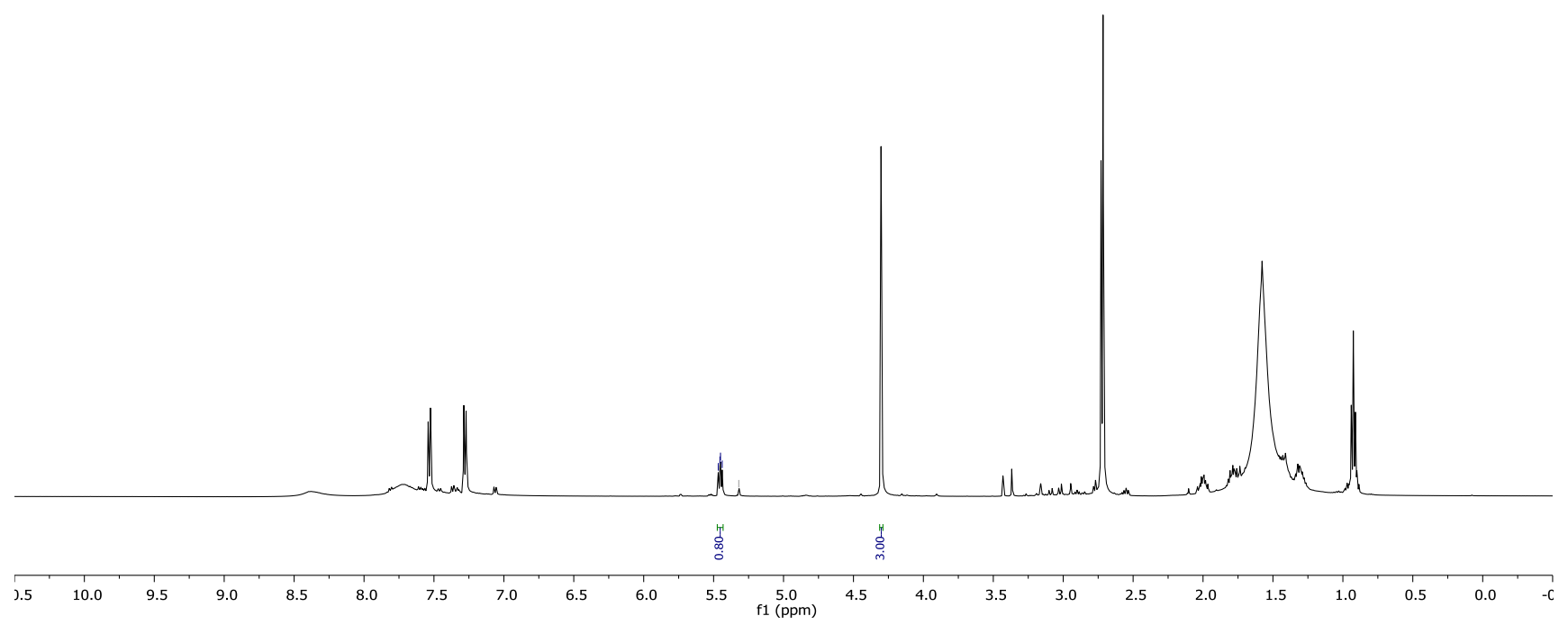

1-(4-Biphenyl) ethanol (3)

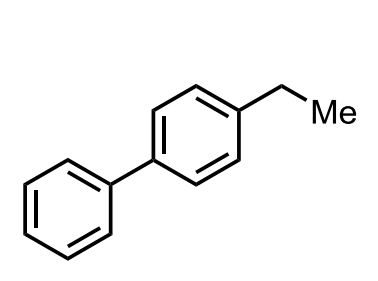

S2
1. $\mathrm{CuOAc}(20 \mathrm{~mol} \%)$

TMSOAC (3 equiv) MsOOMs (1.5 equiv)

$\operatorname{DCM}(0.2 \mathrm{M}), 13 \mathrm{~h}, 23^{\circ} \mathrm{C}$

2. $5 \% \mathrm{NaOMe}$

$\mathrm{MeOH}(0.2 \mathrm{M})$

$2 \mathrm{~h}, 23^{\circ} \mathrm{C}$

$79 \%$

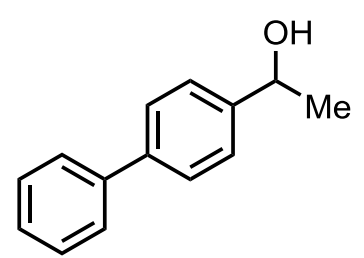

3

In an $\mathrm{N}_{2}$-filled glovebox, to a $4 \mathrm{~mL}$ vial containing a Teflon-coated magnetic stirring bar, CuOAc (4.9 mg, 
$40 \mu \mathrm{mol}, 20 \mathrm{~mol} \%$ ), and 4-ethylbiphenyl (S2) (36.5 mg, $0.200 \mathrm{mmol}, 1.00$ equiv) were added DCM ( $1 \mathrm{~mL}, \mathrm{c}=$ $0.2 \mathrm{M}$ ), TMSOAC (90 $\mathrm{L}, 79 \mathrm{mg}, 0.60 \mathrm{mmol}, 3.0$ equiv), and solid bis(methanesulfonyl) peroxide (57.0 mg, $0.300 \mathrm{mmol}, 1.50$ equiv) at $23^{\circ} \mathrm{C}$. The vial was closed with a Teflon-lined screw cap and removed from the glovebox. The reaction mixture was stirred at $23^{\circ} \mathrm{C}$ for $13 \mathrm{~h}$. Aqueous sodium sulfite solution (10\% (w:w), $1 \mathrm{~mL}$ ) was added to the reaction mixture. The resulting mixture was transferred to a separation funnel and extracted with EtOAc $(3 \times 20 \mathrm{~mL})$. The combined organic layers were washed with brine $(10 \mathrm{~mL})$, dried over $\mathrm{Na}_{2} \mathrm{SO}_{4}$, and concentrated under reduced pressure. To the residue were added $\mathrm{NaOMe}$ in $\mathrm{MeOH}(5 \%$ (w:w), $1 \mathrm{~mL}, \mathrm{c}=0.2 \mathrm{M}$ ). The reaction mixture was stirred for $2 \mathrm{~h}$ at $23^{\circ} \mathrm{C}$. The reaction mixture was diluted with $\mathrm{H}_{2} \mathrm{O}(5 \mathrm{~mL})$ and EtOAc $(10 \mathrm{~mL})$, and the resulting mixture was transferred to a separation funnel. The layers were separated, and the aqueous layer was extracted with EtOAc $(2 \times 10 \mathrm{~mL})$. The combined organic layers were washed with brine $(10 \mathrm{~mL})$, dried over $\mathrm{Na}_{2} \mathrm{SO}_{4}$, and concentrated under reduced pressure. The residue was purified by column chromatography on silica gel eluting with a solvent mixture of ethyl acetate:hexanes (15:85 (v:v)) to afford $31 \mathrm{mg}$ of $\mathbf{3}$ as a colorless solid (79\% yield).

$\mathbf{R}_{f}$ (ethyl acetate:hexanes, 30:70 (v:v)) $=0.28\left(\mathrm{UV}, \mathrm{KMnO}_{4}\right)$.

\section{NMR Spectroscopy:}

${ }^{1}$ H NMR $\left(500 \mathrm{MHz}\right.$, DMSO- $\left.d_{6}, 25^{\circ} \mathrm{C}, \delta\right): 7.66-7.59(\mathrm{~m}, 4 \mathrm{H}), 7.47-7.41(\mathrm{~m}, 4 \mathrm{H}), 7.37-7.32(\mathrm{~m}, 1 \mathrm{H}), 5.18$ $(\mathrm{d}, J=4.3 \mathrm{~Hz}, 1 \mathrm{H}), 4.77$ (qd, $J=6.4,4.1 \mathrm{~Hz}, 1 \mathrm{H}), 1.36(\mathrm{~d}, J=6.5 \mathrm{~Hz}, 3 \mathrm{H})$.

${ }^{13} \mathrm{C}\left\{{ }^{1} \mathrm{H}\right\}$ NMR $\left(126 \mathrm{MHz}\right.$, DMSO- $\left.d_{6}, 25^{\circ} \mathrm{C}, \delta\right): 146.6,140.2,138.4,128.9,127.2,126.5,126.3,125.9,67.8$, 25.9.

HRMS-EI(m/z) calc'd for $\mathrm{C}_{14} \mathrm{H}_{14} \mathrm{O}[\mathrm{M}]^{+}, 198.1041$; found, 198.1039; deviation: -0.93 ppm.

Additional note: The benzylic acetate can be isolated by column chromatography with an eluent mixture of ethylacetate:hexane (10:90 (v:v)) as a colorless solid (85\%) after step 1. See spectral data.

\section{3-Chloro-1-phenylpropan-1-ol (4)}

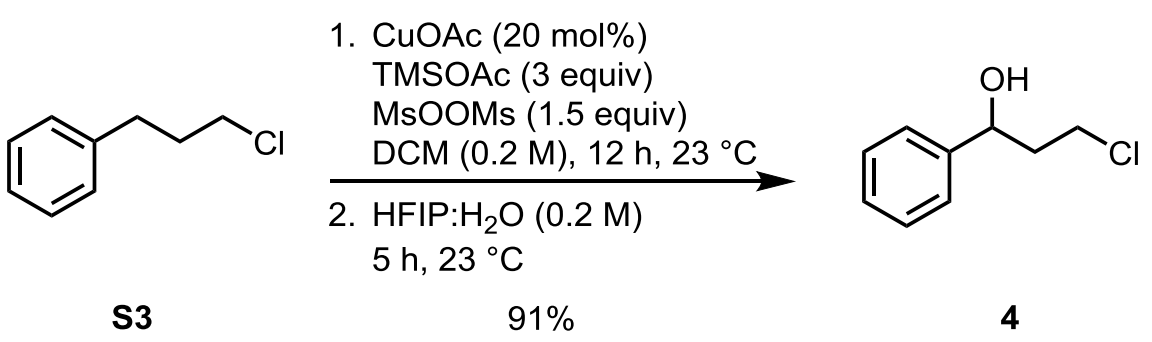

In an $\mathrm{N}_{2}$-filled glovebox, to a $4 \mathrm{~mL}$ vial containing a Teflon-coated magnetic stirring bar, CuOAc (4.9 mg, 40 $\mu \mathrm{mol}, 20 \mathrm{~mol} \%$ ), and 3-phenylpropylchloride (S3) (28.6 $\mu \mathrm{L}, 30.9 \mathrm{mg}, 0.200 \mathrm{mmol}, 1.00$ equiv) were added DCM $(1 \mathrm{~mL}, \mathrm{c}=0.2 \mathrm{M})$, TMSOAc $(90 \mu \mathrm{L}, 79 \mathrm{mg}, 0.60 \mathrm{mmol}, 3.0$ equiv), and solid bis(methanesulfonyl) peroxide (57.0 mg, $0.300 \mathrm{mmol}, 1.50$ equiv) at $23^{\circ} \mathrm{C}$. The vial was closed with a Teflon-lined screw cap and removed from the glovebox. The reaction mixture was stirred at $23{ }^{\circ} \mathrm{C}$ for $12 \mathrm{~h}$. Aqueous sodium sulfite solution $(10 \%(w: w), 1 \mathrm{~mL})$ was added to the reaction mixture. The resulting mixture was transferred to a 
separation funnel and extracted with EtOAc $(3 \times 20 \mathrm{~mL})$. The combined organic layers were washed with brine $(10 \mathrm{~mL})$, dried over $\mathrm{Na}_{2} \mathrm{SO}_{4}$, and concentrated under reduced pressure. To the residue was added HFIP: $\mathrm{H}_{2} \mathrm{O}(1: 1(\mathrm{v}: \mathrm{v}), 1 \mathrm{~mL}, \mathrm{C}=0.2 \mathrm{M})$. The reaction mixture was stirred for $5 \mathrm{~h}$ at $23^{\circ} \mathrm{C}$. The reaction mixture was diluted with $\mathrm{H}_{2} \mathrm{O}(5 \mathrm{~mL})$ and EtOAc $(10 \mathrm{~mL})$, and the resulting mixture was transferred to a separation funnel. The layers were separated, and the aqueous layer was extracted with EtOAc $(2 \times 10 \mathrm{~mL})$. The combined organic layers were washed with brine $(10 \mathrm{~mL})$, dried over $\mathrm{Na}_{2} \mathrm{SO}_{4}$, and concentrated under reduced pressure. The residue was purified by column chromatography on silica gel eluting with a solvent mixture of ethyl acetate:hexanes (07:93 (v:v)) to afford $31 \mathrm{mg}$ of 4 as a colorless liquid (91\% yield).

$\mathbf{R}_{f}$ (ethyl acetate:hexanes, 10:90 (v:v)) $=0.21(\mathrm{UV}, \mathrm{CAM})$

\section{NMR Spectroscopy:}

${ }^{1}$ H NMR $\left(500 \mathrm{MHz}, \mathrm{CDCl}_{3}, 25^{\circ} \mathrm{C}, \delta\right): 7.37(\mathrm{~d}, J=4.4 \mathrm{~Hz}, 4 \mathrm{H}), 7.33-7.28(\mathrm{~m}, 1 \mathrm{H}), 4.94(\mathrm{dd}, J=8.5,4.7 \mathrm{~Hz}$, $1 \mathrm{H}$ ), 3.74 (ddd, $J=10.9,8.2,5.6 \mathrm{~Hz}, 1 \mathrm{H}), 3.56(\mathrm{dt}, J=10.9,6.0 \mathrm{~Hz}, 1 \mathrm{H}), 2.24(\mathrm{~m}, J=14.3,8.5,5.7 \mathrm{~Hz}, 1 \mathrm{H}$ ), $2.14-2.03(\mathrm{~m}, 2 \mathrm{H})$.

${ }^{13} \mathrm{C}\left\{{ }^{1} \mathrm{H}\right\}$ NMR $\left(126 \mathrm{MHz}, \mathrm{CDCl}_{3}, 25^{\circ} \mathrm{C}, \delta\right): 143.6,128.6,128.0,125.6,71.4,41.9,41.6$.

HRMS-El (m/z) calc'd for $\mathrm{C}_{9} \mathrm{H}_{11} \mathrm{OCl}\left[\mathrm{MT}^{+}, 170.0500\right.$; found, 170.0498; deviation: $-1.03 \mathrm{ppm}$.

${ }^{1} \mathrm{H}$ NMR of reaction mixture after step 1 and aqueous work-up with $\mathrm{CH}_{3} \mathrm{NO}_{2}$ as internal standard:

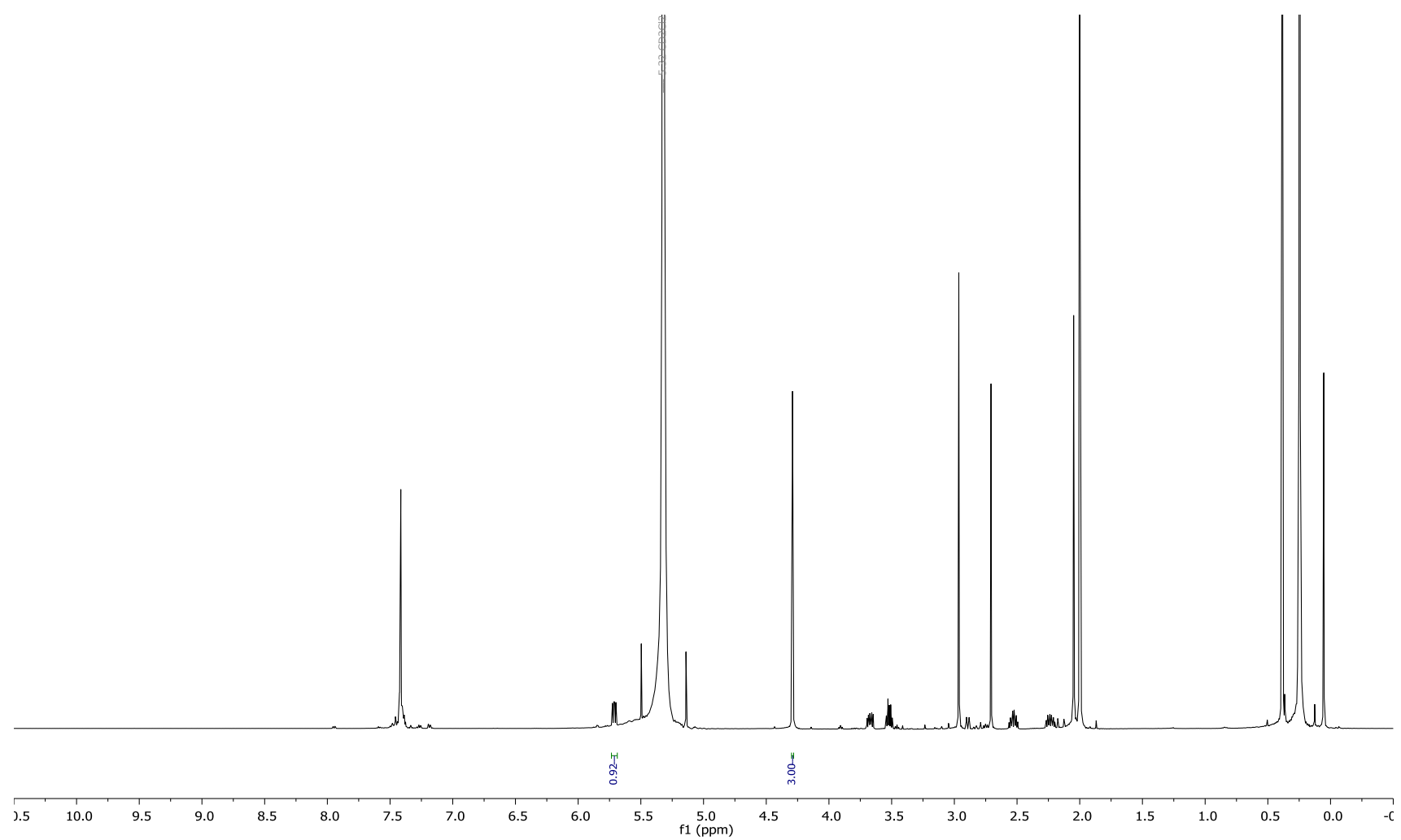


3-Methyl-1-phenylbutan-1-ol (5)<smiles>CC(C)CCc1ccccc1</smiles>

S4
1. TMSOAc ( 1.5 equiv) MsOOMs (1.5 equiv) $\operatorname{DCM}(0.2 \mathrm{M}), 30 \mathrm{~min}, 23^{\circ} \mathrm{C}$

2. $\mathrm{HFIP}: \mathrm{H}_{2} \mathrm{O}(0.2 \mathrm{M})$ $7 \mathrm{~h}, 23^{\circ} \mathrm{C}$<smiles>CC(C)CC(O)c1ccccc1</smiles>

5

In an $\mathrm{N}_{2}$-filled glovebox, to a $4 \mathrm{~mL}$ vial containing a Teflon-coated magnetic stirring bar, and isopentylbenzene (S4) $(34.7 \mu \mathrm{L}, 29.6 \mathrm{mg}, 0.200 \mathrm{mmol}, 1.00$ equiv) were added DCM (1 mL, c = 0.2 M), TMSOAc (45 $\mu \mathrm{L}, 40$ $\mathrm{mg}, 0.30 \mathrm{mmol}, 1.5$ equiv), and solid bis(methanesulfonyl) peroxide (57.0 mg, $0.300 \mathrm{mmol}, 1.50$ equiv) at $23{ }^{\circ} \mathrm{C}$. The vial was closed with a Teflon-lined screw cap and removed from the glovebox. The reaction mixture was stirred at $23^{\circ} \mathrm{C}$ for 30 minutes. Aqueous sodium sulfite solution (10\% (w:w), $1 \mathrm{~mL}$ ) was added to the reaction mixture. The resulting mixture was transferred to a separation funnel and extracted with EtOAc $(3 \times 20 \mathrm{~mL})$. The combined organic layers were washed with brine $(10 \mathrm{~mL})$, dried over $\mathrm{Na}_{2} \mathrm{SO}_{4}$, and concentrated under reduced pressure. To the residue was added HFIP: $\mathrm{H}_{2} \mathrm{O}(1: 1$ (v:v), $1 \mathrm{~mL}, \mathrm{c}=0.2 \mathrm{M})$. The reaction mixture was stirred for $7 \mathrm{~h}$ at $23^{\circ} \mathrm{C}$. The reaction mixture was concentrated under reduced pressure The obtained residue was purified by column chromatography on silica gel eluting with a solvent mixture of ethyl acetate:hexanes (10:90 (v:v)) to afford $19 \mathrm{mg}$ of 5 as a colorless liquid (58\% yield).

$\mathbf{R}_{f}$ (ethyl acetate:hexanes, 20:80 (v:v)) $=0.44(U V$, CAM).

\section{NMR Spectroscopy:}

${ }^{1}$ H NMR $\left(500 \mathrm{MHz}, \mathrm{CDCl}_{3}, 25 \stackrel{\circ}{\circ} \mathrm{C}, \delta\right): 7.38-7.33(\mathrm{~m}, 4 \mathrm{H}), 7.31-7.27(\mathrm{~m}, 1 \mathrm{H}), 4.75(\mathrm{dd}, J=8.1,5.3 \mathrm{~Hz}, 1 \mathrm{H})$, $1.78-1.67(\mathrm{~m}, 3 \mathrm{H}), 1.55-1.48(\mathrm{~m}, 1 \mathrm{H}), 0.96(\mathrm{dd}, J=6.5,2.5 \mathrm{~Hz}, 6 \mathrm{H})$.

${ }^{13} \mathrm{C}\left\{{ }^{1} \mathrm{H}\right\}$ NMR $\left(126 \mathrm{MHz}, \mathrm{CDCl}_{3}, 25^{\circ} \mathrm{C}, \delta\right): 145.4,128.6,127.7,126.1,72.9,48.5,24.9,23.3,22.4$.

HRMS-EI(m/z) calc'd for $\mathrm{C}_{11} \mathrm{H}_{16} \mathrm{O}[\mathrm{M}]^{+}, 164.11961$; found, 164.11956; deviation: $-0.27 \mathrm{ppm}$

${ }^{1} \mathrm{H}$ NMR of reaction mixture after step 1 : 


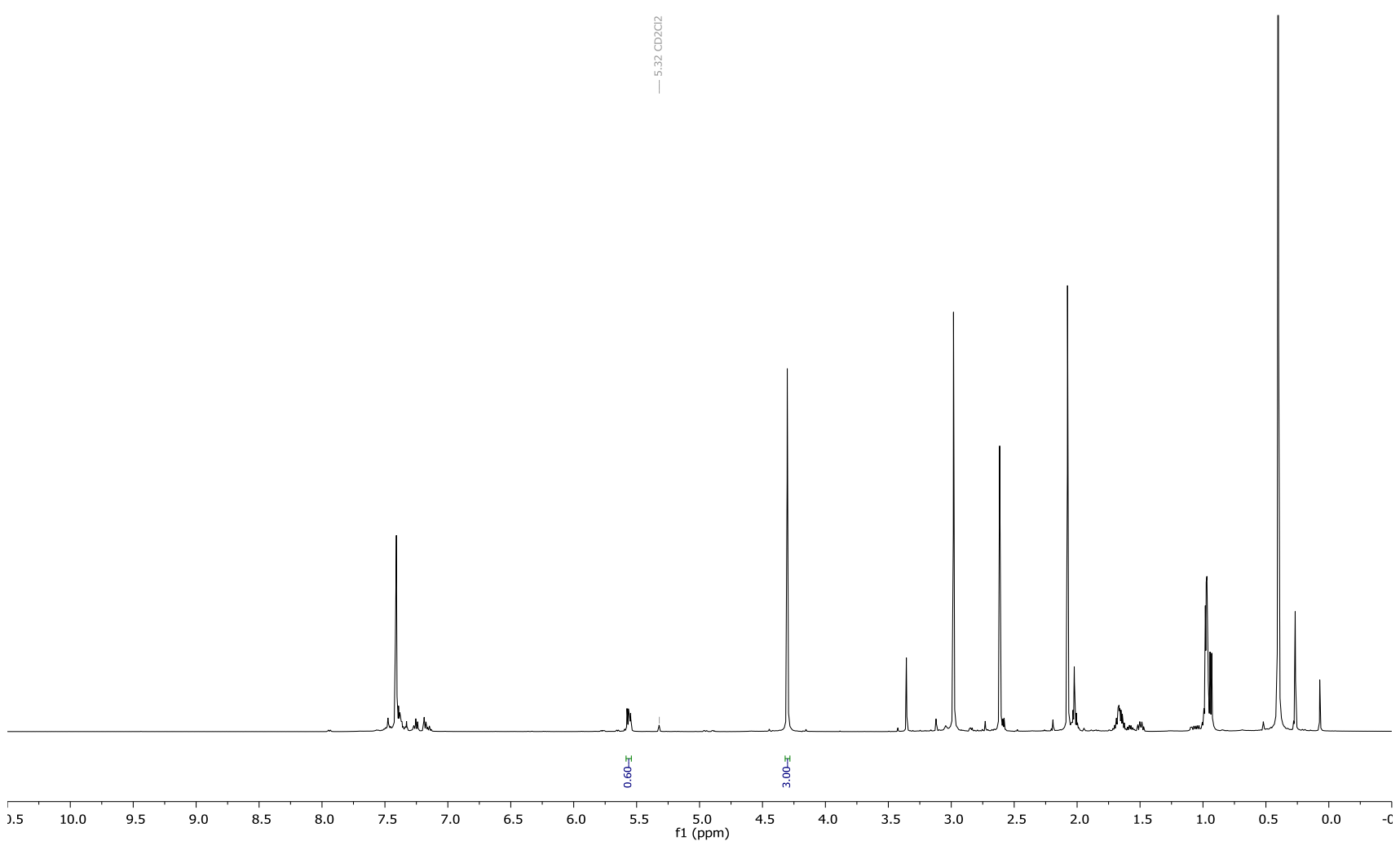

\section{3-Bromo-1-(4-methoxyphenyl) propan-1-ol (6)}

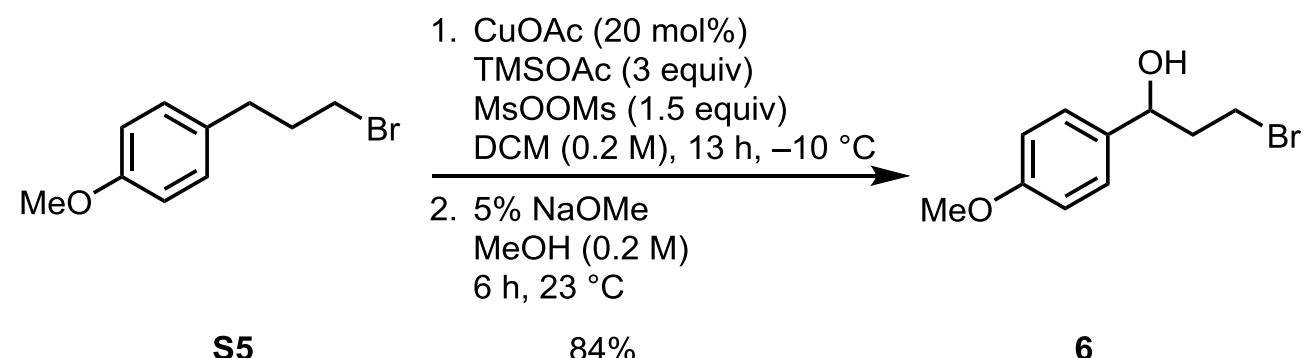

S5

$84 \%$

6

In an $\mathrm{N}_{2}$-filled glovebox, to a $4 \mathrm{~mL}$ vial containing a Teflon-coated magnetic stirring bar, CuOAc (4.9 mg, 40 umol, $20 \mathrm{~mol} \%$ ), and 1-(3-brompropyl)-4-methoxybenzol (S5) (34.9 $\mu \mathrm{L}, 45.8 \mathrm{mg}, 0.200 \mathrm{mmol}, 1.00$ equiv) were added DCM (1 mL, c = $0.2 \mathrm{M})$, TMSOAc $(90 \mu \mathrm{L}, 79 \mathrm{mg}, 0.60 \mathrm{mmol}, 3.0$ equiv), and solid bis(methanesulfonyl) peroxide $\left(57.0 \mathrm{mg}, 0.300 \mathrm{mmol}, 1.50\right.$ equiv) at $-50{ }^{\circ} \mathrm{C}$. The vial was closed with a Teflon-lined screw cap and removed from the glovebox. The reaction mixture was stirred at $-10^{\circ} \mathrm{C}$ for $13 \mathrm{~h}$. Aqueous sodium sulfite solution $(10 \%(\mathrm{w} / \mathrm{w}), 1 \mathrm{~mL})$ was added to the reaction mixture. The resulting mixture was transferred to a separation funnel and extracted with EtOAc $(3 \times 20 \mathrm{~mL})$. The combined organic layers were washed with brine $(10 \mathrm{~mL})$, dried over $\mathrm{Na}_{2} \mathrm{SO}_{4}$, and concentrated under reduced pressure. To the residue were added $\mathrm{NaOMe}$ in $\mathrm{MeOH}(5 \%(w: w) ; 1 \mathrm{~mL}, \mathrm{c}=0.2 \mathrm{M})$. The reaction mixture was stirred for $6 \mathrm{~h}$ at $23^{\circ} \mathrm{C}$. The reaction mixture was diluted with $\mathrm{H}_{2} \mathrm{O}(5 \mathrm{~mL})$ and $\mathrm{EtOAc}(10 \mathrm{~mL})$, and the resulting mixture was transferred to a separation funnel. The layers were separated, and the aqueous layer was extracted with EtOAc $(2 \times 10 \mathrm{~mL})$. The combined organic layers were washed with brine $(10 \mathrm{~mL})$, dried over $\mathrm{Na}_{2} \mathrm{SO}_{4}$, and concentrated under reduced pressure. The residue was purified by column chromatography on silica gel 
eluting with a solvent mixture of ethyl acetate:hexanes $(20: 80(\mathrm{v}: \mathrm{v}))$ to afford $41 \mathrm{mg}$ of 6 as a colorless solid (84\% yield).

$\mathbf{R}_{\boldsymbol{f}}$ (ethyl acetate:hexanes, 30:70 (v:v)) $=0.41\left(\mathrm{UV}, \mathrm{KMnO}_{4}\right)$.

\section{NMR Spectroscopy:}

${ }^{1}$ H NMR (500 MHz, $\left.\mathrm{CDCl}_{3}, 25^{\circ} \mathrm{C}, \delta\right): 7.30-7.28(\mathrm{~m}, 2 \mathrm{H}), 6.91-6.88(\mathrm{~m}, 2 \mathrm{H}), 4.86(\mathrm{dd}, J=8.2,4.9 \mathrm{~Hz}, 1 \mathrm{H})$, $3.81(\mathrm{~d}, J=0.9 \mathrm{~Hz}, 3 \mathrm{H}), 3.55(\mathrm{~m}, J=10.0,7.9,6.0 \mathrm{~Hz}, 1 \mathrm{H}), 3.39(\mathrm{dt}, J=10.0,6.2 \mathrm{~Hz}, 1 \mathrm{H}), 2.32(\mathrm{~m}, J=14.3$, 8.4, 6.1 Hz, 1H), $2.19-2.11(\mathrm{~m}, 1 \mathrm{H}), 1.97(\mathrm{bs}, 1 \mathrm{H})$.

${ }^{13} \mathrm{C}\left\{{ }^{1} \mathrm{H}\right\}$ NMR $\left(126 \mathrm{MHz}, \mathrm{CDCl}_{3}, 25^{\circ} \mathrm{C}, \delta\right): 159.3,135.6,127.1,114.0,72.0,55.4,41.3,30.4$.

HRMS-ESI(m/z) calc'd for $\mathrm{C}_{10} \mathrm{H}_{13} \mathrm{O}_{2} \mathrm{Br}[\mathrm{M}+\mathrm{Na}]^{+}, 266.9988$; found, 266.9991; deviation: +1.14 ppm.

\section{4-(1-Hydroxybutyl) benzonitrile (7)}

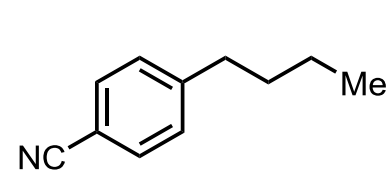

S6
1. CuOAc $(20 \mathrm{~mol} \%)$ TMSOAC (3 equiv) MsOOMs (1.5 equiv) $\operatorname{DCM}(0.2 \mathrm{M}), 12 \mathrm{~h}, 23^{\circ} \mathrm{C}$

2. HFIP: $\mathrm{H}_{2} \mathrm{O}(0.2 \mathrm{M})$ $6 \mathrm{~h}, 23^{\circ} \mathrm{C}$

$72 \%$<smiles>CCCC(O)c1ccc(C#N)cc1</smiles>

7

In an $\mathrm{N}_{2}$-filled glovebox, to a $4 \mathrm{~mL}$ vial containing a Teflon-coated magnetic stirring bar, CuOAc (4.9 mg, 40 $\mu \mathrm{mol}, 20 \mathrm{~mol} \%$ ), and 4-butylbenzonitrile (S6) $(34.6 \mu \mathrm{L}, 31.8 \mathrm{mg}, 0.200 \mathrm{mmol}, 1.00$ equiv) were added DCM $(1 \mathrm{~mL}, \mathrm{c}=0.2 \mathrm{M})$, TMSOAc $(90 \mu \mathrm{L}, 79 \mathrm{mg}, 0.60 \mathrm{mmol}, 3.0$ equiv), and solid bis(methanesulfonyl) peroxide (57.0 mg, $0.300 \mathrm{mmol}, 1.50$ equiv) at $23^{\circ} \mathrm{C}$. The vial was closed with a Teflon-lined screw cap and removed from the glovebox. The reaction mixture was stirred at $23{ }^{\circ} \mathrm{C}$ for $12 \mathrm{~h}$. Aqueous sodium sulfite solution $(10 \%$ $(w: w), 1 \mathrm{~mL}$ ) was added to the reaction mixture. The resulting mixture was transferred to a separation funnel and extracted with EtOAc $(3 \times 20 \mathrm{~mL})$. The combined organic layers were washed with brine $(10 \mathrm{~mL})$, dried over $\mathrm{Na}_{2} \mathrm{SO}_{4}$, and concentrated under reduced pressure. To the residue was added HFIP: $\mathrm{H}_{2} \mathrm{O}(1: 1$ (v:v), 1 $\mathrm{mL}, \mathrm{c}=0.2 \mathrm{M}$ ). The reaction mixture was stirred for $6 \mathrm{~h}$ at $23^{\circ} \mathrm{C}$. The reaction mixture was diluted with $\mathrm{H}_{2} \mathrm{O}$ $(5 \mathrm{~mL})$ and EtOAc $(10 \mathrm{~mL})$, and the resulting mixture was transferred to a separation funnel. The layers were separated, and the aqueous layer was extracted with EtOAc $(2 \times 10 \mathrm{~mL})$. The combined organic layers were washed with brine $(10 \mathrm{~mL})$, dried over $\mathrm{Na}_{2} \mathrm{SO}_{4}$, and concentrated under reduced pressure. The residue was purified by column chromatography on silica gel eluting with a solvent mixture of ethyl acetate:hexanes (10:90 (v:v)) to afford $25 \mathrm{mg}$ of 7 as a colorless liquid (72\% yield).

$\mathbf{R}_{\boldsymbol{f}}$ (ethyl acetate:hexanes, 20:80 (v:v)) $=0.16\left(\mathrm{UV}, \mathrm{KMnO}_{4}\right)$.

\section{NMR Spectroscopy:}

${ }^{1}$ H NMR $\left(500 \mathrm{MHz}, \mathrm{CDCl}_{3}, 25{ }^{\circ} \mathrm{C}, \delta\right): 7.65-7.60(\mathrm{~m}, 2 \mathrm{H}), 7.45(\mathrm{~d}, J=7.9 \mathrm{~Hz}, 2 \mathrm{H}), 4.75(\mathrm{dd}, J=7.7,5.4 \mathrm{~Hz}$, $1 \mathrm{H}), 1.89$ (bs, $1 \mathrm{H}), 1.75(\mathrm{~m}, J=13.3,10.1,7.7,5.2 \mathrm{~Hz}, 1 \mathrm{H}), 1.70-1.62(\mathrm{~m}, 1 \mathrm{H}), 1.49-1.39(\mathrm{~m}, 1 \mathrm{H}), 1.38-$ $1.28(\mathrm{~m}, 1 \mathrm{H}), 0.93(\mathrm{dd}, J=8.0,6.9 \mathrm{~Hz}, 3 \mathrm{H})$. 
${ }^{13} \mathrm{C}\left\{{ }^{1} \mathrm{H}\right\} \operatorname{NMR}\left(126 \mathrm{MHz}, \mathrm{CDCl}_{3}, 25^{\circ} \mathrm{C}, \delta\right): 150.6,132.6,126.91,119.3,111.5,73.7,41.4,18.9,14.1$.

HRMS-EI(m/z) calc'd for $\mathrm{C}_{11} \mathrm{H}_{13} \mathrm{NO}\left[\mathrm{M}^{+}{ }^{+}, 175.09924\right.$; found, 175.09916; deviation: $-0.44 \mathrm{ppm}$.

1-Phenylbut-3-en-1-ol (8)

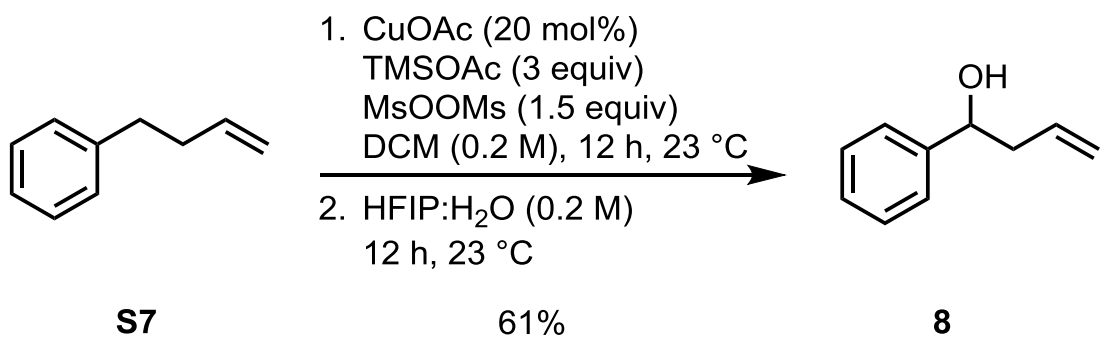

In an $\mathrm{N}_{2}$-filled glovebox, to a $4 \mathrm{~mL}$ vial containing a Teflon-coated magnetic stirring bar, CuOAc (4.9 mg, $40 \mu \mathrm{mol}, 20 \mathrm{~mol} \%$ ), and 4-phenyl-1-butene (S7) (30 $\mu \mathrm{L}, 26.5 \mathrm{mg}, 0.200 \mathrm{mmol}, 1.00$ equiv) were added DCM $(1 \mathrm{~mL}, \mathrm{c}=0.2 \mathrm{M})$, TMSOAc $(90 \mu \mathrm{L}, 79 \mathrm{mg}, 0.60 \mathrm{mmol}, 3.0$ equiv), and solid bis(methanesulfonyl) peroxide ( $57.0 \mathrm{mg}, 0.300 \mathrm{mmol}, 1.50$ equiv) at $23^{\circ} \mathrm{C}$. The vial was closed with a Teflon-lined screw cap and removed from the glovebox. The reaction mixture was stirred at $23^{\circ} \mathrm{C}$ for $12 \mathrm{~h}$. Aqueous sodium sulfite solution $(10 \%$ $(w: w), 1 \mathrm{~mL}$ ) was added to the reaction mixture. The resulting mixture was transferred to a separation funnel and extracted with EtOAc $(3 \times 20 \mathrm{~mL})$. The combined organic layers were washed with brine $(10 \mathrm{~mL})$, dried over $\mathrm{Na}_{2} \mathrm{SO}_{4}$, and concentrated under reduced pressure. To the residue was added HFIP:H $\mathrm{H}_{2} \mathrm{O}(1: 1$ (v:v), $1 \mathrm{~mL}, \mathrm{C}=0.2 \mathrm{M}$ ). The reaction mixture was stirred for $12 \mathrm{~h}$ at $23^{\circ} \mathrm{C}$. The reaction mixture was diluted with $\mathrm{H}_{2} \mathrm{O}(5 \mathrm{~mL})$ and EtOAc $(10 \mathrm{~mL})$, and the resulting mixture was transferred to a separation funnel. The layers were separated, and the aqueous layer was extracted with EtOAc $(2 \times 10 \mathrm{~mL})$. The combined organic layers were washed with brine $(10 \mathrm{~mL})$, dried over $\mathrm{Na}_{2} \mathrm{SO}_{4}$, and concentrated under reduced pressure. The residue was purified by column chromatography on silica gel eluting with a solvent mixture of ethyl acetate:hexanes $(10: 90(v: v))$ to afford $18 \mathrm{mg}$ of 8 as a colorless liquid (61\% yield).

$\mathbf{R}_{\boldsymbol{f}}$ (ethyl acetate:hexanes, 10:90 (v:v)) $=0.31(\mathrm{UV}, \mathrm{CAM})$

\section{NMR Spectroscopy:}

${ }^{1} \mathrm{H}$ NMR $\left(500 \mathrm{MHz}, \mathrm{CDCl}_{3}, 25^{\circ} \mathrm{C}, \delta\right): 7.36(\mathrm{~d}, J=3.9 \mathrm{~Hz}, 4 \mathrm{H}), 7.32-7.25(\mathrm{~m}, 1 \mathrm{H}), 5.81(\mathrm{~m}, J=17.2,10.2$, $7.1 \mathrm{~Hz}, 1 \mathrm{H}), 5.18-5.09(\mathrm{~m}, 2 \mathrm{H}), 4.71(\mathrm{~m}, J=7.4,5.6,1.9 \mathrm{~Hz}, 1 \mathrm{H}), 2.53-2.49(\mathrm{~m}, 2 \mathrm{H}), 2.35-2.28(\mathrm{~m}, 1 \mathrm{H})$.

${ }^{13} \mathrm{C}\left\{{ }^{1} \mathrm{H}\right\}$ NMR $\left(126 \mathrm{MHz}, \mathrm{CDCl}_{3}, 25^{\circ} \mathrm{C}, \delta\right): 143.9,134.5,128.4,127.5,125.9,118.3,73.4,43.8$.

HRMS-ESI (m/z) calc'd for $\mathrm{C}_{10} \mathrm{H}_{12} \mathrm{O}_{1}[\mathrm{M}+\mathrm{Na}]^{+}, 171.0781$; found, 171.0780; deviation: $-0.56 \mathrm{ppm}$. 
1-Phenylpent-4-yn-1-ol (9)

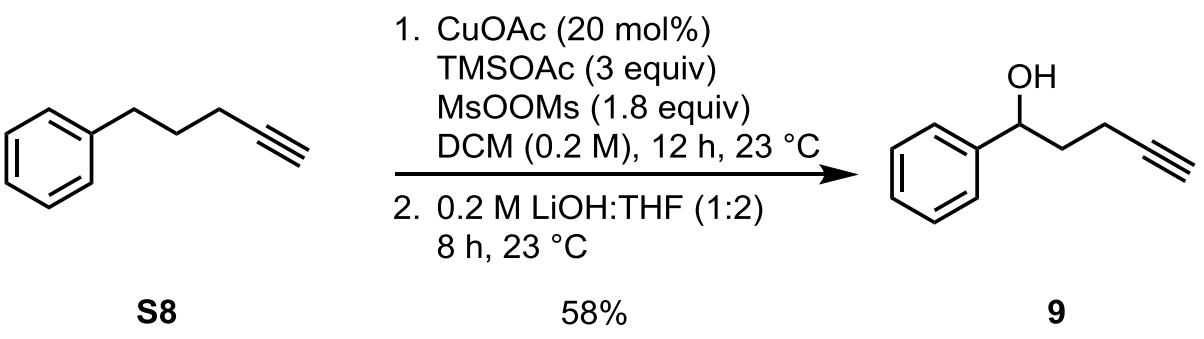

In an $\mathrm{N}_{2}$-filled glovebox, to a $4 \mathrm{~mL}$ vial containing a Teflon-coated magnetic stirring bar, CuOAc $(7.4 \mathrm{mg}, 60$ $\mu \mathrm{mol}, 20 \mathrm{~mol} \%$ ), and 5-phenyl-1-pentyne (S8) (45.6 $\mu \mathrm{L}, 43.3 \mathrm{mg}, 0.300 \mathrm{mmol}, 1.00$ equiv) were added DCM $(1.5 \mathrm{~mL}, \mathrm{c}=0.20 \mathrm{M}), \mathrm{TMSOAc}(135 \mu \mathrm{L}, 119 \mathrm{mg}, 0.900 \mathrm{mmol}, 3.00$ equiv), and solid bis(methanesulfonyl) peroxide (103 mg, $0.540 \mathrm{mmol}, 1.80$ equiv) at $23^{\circ} \mathrm{C}$. The vial was closed with a Teflon-lined screw cap and removed from the glovebox. The reaction mixture was stirred at $23{ }^{\circ} \mathrm{C}$ for $12 \mathrm{~h}$. Aqueous sodium sulfite solution $(10 \%(w: w), 1 \mathrm{~mL})$ was added to the reaction mixture. The resulting mixture was transferred to a separation funnel and extracted with EtOAc $(3 \times 20 \mathrm{~mL})$. The combined organic layers were washed with brine $(10 \mathrm{~mL})$, dried over $\mathrm{Na}_{2} \mathrm{SO}_{4}$, and concentrated under reduced pressure. To the residue was added $0.2 \mathrm{M}$ aqueous LiOH:THF (1:2 (v:v), $1.5 \mathrm{~mL}, \mathrm{c}=0.20 \mathrm{M})$. The reaction mixture was stirred for $7 \mathrm{~h}$ at $23^{\circ} \mathrm{C}$. The reaction mixture was concentrated under reduced pressure. The residue was purified by column chromatography on silica gel eluting with a solvent mixture of ethyl acetate:hexanes $(5: 95(\mathrm{v}: \mathrm{v}))$ to afford $28 \mathrm{mg}$ of 9 as a colorless liquid (58\% yield).

$\mathbf{R}_{f}$ (ethyl acetate:hexanes, 20:80 (v:v)) =0.34 (UV-inactive, $\left.\mathrm{KMnO}_{4}\right)$.

\section{NMR Spectroscopy:}

${ }^{1}$ H NMR $\left(500 \mathrm{MHz}, \mathrm{CDCl}_{3}, 25^{\circ} \mathrm{C}, \delta\right) .7 .38-7.34(\mathrm{~m}, 4 \mathrm{H}), 7.31-7.26(\mathrm{~m}, 1 \mathrm{H}), 4.86(\mathrm{dd}, J=8.2,5.0 \mathrm{~Hz}, 1 \mathrm{H})$, $2.36(\mathrm{~m}, J=17.2,7.4,2.7 \mathrm{~Hz}, 1 \mathrm{H}), 2.24(\mathrm{~m}, J=16.8,6.7,2.7 \mathrm{~Hz}, 1 \mathrm{H}), 2.04-1.88(\mathrm{~m}, 4 \mathrm{H})$.

${ }^{13} \mathrm{C}\left\{{ }^{1} \mathrm{H}\right\} \operatorname{NMR}\left(126 \mathrm{MHz}, \mathrm{CDCl}_{3}, 25^{\circ} \mathrm{C}, \delta\right): 144.1,128.6,127.7,125.9,84.0,73.3,69.1,37.5,15.3$.

HRMS-El (m/z) calc'd for $\mathrm{C}_{11} \mathrm{H}_{12} \mathrm{O}[\mathrm{M}]^{+}, 160.08827$; found, 160.08826; deviation: -0.03 ppm.

(4-Isocyanophenyl) methanol (10)<smiles>Cc1ccc(C#N)cc1</smiles>

1. CuOAc (20 mol\%)

MsOOMs ( 1.5 equiv)

TMSOAc ( 3 equiv) $\operatorname{DCM}(0.2 \mathrm{M}), 6 \mathrm{~h}, 23^{\circ} \mathrm{C}$

2. $\mathrm{Cs}_{2} \mathrm{CO}_{3}$ (3 equiv) DMF: $\mathrm{H}_{2} \mathrm{O}(0.2 \mathrm{M})$

$24 \mathrm{~h}, 50^{\circ} \mathrm{C}$<smiles>N#Cc1ccc(CO)cc1</smiles>

10

In an $\mathrm{N}_{2}$-filled glovebox, to a $4 \mathrm{~mL}$ vial containing a Teflon-coated magnetic stirring bar, CuOAc (4.9 mg, $40 \mu \mathrm{mol}, 20 \mathrm{~mol} \%$ ), and 4-cyanotoluene (S9) $(24.0 \mu \mathrm{L}, 23.5 \mathrm{mg}, 0.200 \mathrm{mmol}, 1.00$ equiv) were added DCM 
( $1 \mathrm{~mL}, \mathrm{c}=0.2 \mathrm{M})$, TMSOAc (45 $\mu \mathrm{L}, 79 \mathrm{mg}, 0.60 \mathrm{mmol}, 1.5$ equiv), and solid bis(methanesulfonyl) peroxide (57.0 mg, $0.300 \mathrm{mmol}, 1.50$ equiv) at $23^{\circ} \mathrm{C}$. The vial was closed with a Teflon-lined screw cap and removed from the glovebox. The reaction mixture was stirred at $23^{\circ} \mathrm{C}$ for $6 \mathrm{~h}$. Aqueous sodium sulfite solution $(10 \%$ $(w: w), 1 \mathrm{~mL}$ ) was added to the reaction mixture. The resulting mixture was transferred to a separation funnel and extracted with EtOAc $(3 \times 20 \mathrm{~mL})$. The combined organic layers were washed with brine $(10 \mathrm{~mL})$, dried over $\mathrm{Na}_{2} \mathrm{SO}_{4}$, and concentrated under reduced pressure. To the residue were added $\mathrm{Cs}_{2} \mathrm{CO}_{3}(195.5 \mathrm{mg}$, $0.6000 \mathrm{mmol}, 3$ equiv) in DMF: $\mathrm{H}_{2} \mathrm{O}(1: 1(\mathrm{v}: \mathrm{v}), 1 \mathrm{~mL}, \mathrm{c}=0.2 \mathrm{M})$. The reaction mixture was stirred for $24 \mathrm{~h}$ at $50{ }^{\circ} \mathrm{C}$. The reaction mixture was diluted with $\mathrm{H}_{2} \mathrm{O}(5 \mathrm{~mL})$ and EtOAc $(10 \mathrm{~mL})$, and the resulting mixture was transferred to a separation funnel. The layers were separated, and the aqueous layer was extracted with EtOAc $(2 \times 10 \mathrm{~mL})$. The combined organic layers were washed with brine $(10 \mathrm{~mL})$, dried over $\mathrm{Na}_{2} \mathrm{SO}_{4}$, and concentrated under reduced pressure. The residue was purified by column chromatography on silica gel eluting with a solvent mixture of ethyl acetate:hexanes (25:75 (v:v)) to afford 18 mg of 10 as a colorless solid (67\% yield).

$\mathbf{R}_{f}$ (ethyl acetate:hexanes, 50:50 (v:v)) $=0.31$ (UV, CAM).

\section{NMR Spectroscopy:}

${ }^{1}$ H NMR $\left(500 \mathrm{MHz}, \mathrm{CDCl}_{3}, 25^{\circ} \mathrm{C}, \delta\right): \delta 7.65-7.63(\mathrm{~m}, 2 \mathrm{H}), 7.47$ (d, J = $\left.7.8 \mathrm{~Hz}, 2 \mathrm{H}\right), 4.78(\mathrm{~s}, 2 \mathrm{H}), 1.91$ (bs, $1 \mathrm{H})$.

${ }^{13} \mathrm{C}\left\{{ }^{1} \mathrm{H}\right\}$ NMR $\left(126 \mathrm{MHz}, \mathrm{CDCl}_{3}, 25^{\circ} \mathrm{C}, \delta\right): \delta 146.3,132.4,127.1,118.9,111.2,64.3$.

HRMS-EI(m/z) calc'd for $\mathrm{C}_{8} \mathrm{H}_{7} \mathrm{NO}\left[\mathrm{M}^{+}, 133.0523\right.$; found, 133.0522; deviation: $-0.87 \mathrm{ppm}$.

Methyl 4-(hydroxymethyl) benzoate (11)

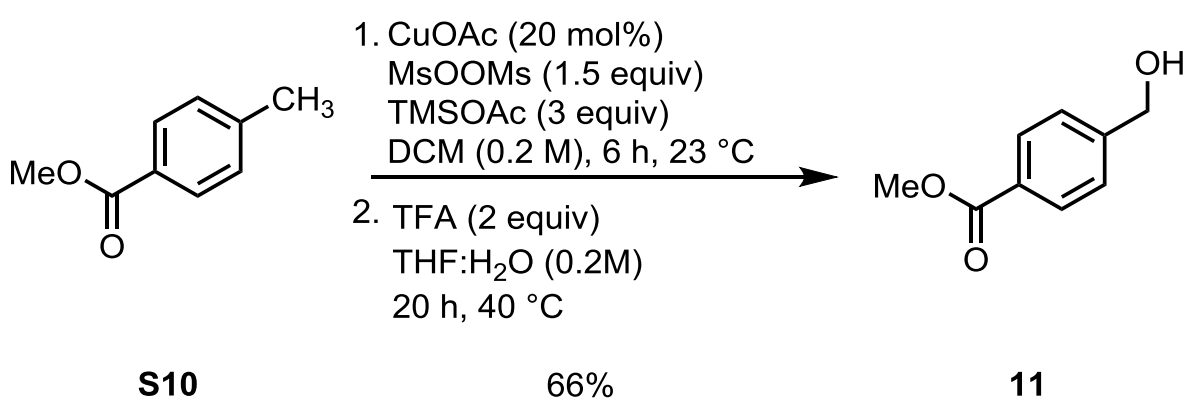

In an $\mathrm{N}_{2}$-filled glovebox, to a $4 \mathrm{~mL}$ vial containing a Teflon-coated magnetic stirring bar, CuOAc (4.9 mg, 40 $\mu \mathrm{mol}, 20 \mathrm{~mol} \%$ ), and methyl-4-methylbenzoate (S10) (30.0 mg, $0.200 \mathrm{mmol}, 1.00$ equiv) were added DCM $(1 \mathrm{~mL}, \mathrm{c}=0.2 \mathrm{M})$, TMSOAc $(45 \mu \mathrm{L}, 79 \mathrm{mg}, 0.60 \mathrm{mmol}, 1.5$ equiv), and solid bis(methanesulfonyl) peroxide (57.0 mg, $0.300 \mathrm{mmol}, 1.50$ equiv) at $23^{\circ} \mathrm{C}$. The vial was closed with a Teflon-lined screw cap and removed from the glovebox. The reaction mixture was stirred at $23^{\circ} \mathrm{C}$ for $6 \mathrm{~h}$. Aqueous sodium sulfite solution $(10 \%$ (w:w), $1 \mathrm{~mL}$ ) was added to the reaction mixture. The resulting mixture was transferred to a separation funnel and extracted with EtOAc $(3 \times 20 \mathrm{~mL})$. The combined organic layers were washed with brine $(10 \mathrm{~mL})$, dried over $\mathrm{Na}_{2} \mathrm{SO}_{4}$, and concentrated under reduced pressure. To the residue were added TFA (31.0 $\mu \mathrm{L}, 45.6 \mathrm{mg}$, 
2 equiv) in THF: $\mathrm{H}_{2} \mathrm{O}(1: 1$ (v:v), $1 \mathrm{~mL}, \mathrm{C}=0.2 \mathrm{M})$. The reaction mixture was stirred for $20 \mathrm{~h}$ at $40{ }^{\circ} \mathrm{C}$. The reaction mixture was diluted with $\mathrm{H}_{2} \mathrm{O}(5 \mathrm{~mL})$ and EtOAc $(10 \mathrm{~mL})$, and the resulting mixture was transferred to a separation funnel. The layers were separated, and the aqueous layer was extracted with EtOAc $(2 \times 10$ $\mathrm{mL})$. The combined organic layers were washed with brine $(10 \mathrm{~mL})$, dried over $\mathrm{Na}_{2} \mathrm{SO}_{4}$, and concentrated under reduced pressure. The residue was purified by column chromatography on silica gel eluting with a solvent mixture of ethyl acetate:hexanes (15:85 (v:v)) to afford $22 \mathrm{mg}$ of $\mathbf{1 1}$ as a colorless solid (66\% yield).

$\mathbf{R}_{\boldsymbol{f}}$ (ethyl acetate:hexanes, 30:70 (v:v)) $=0.22$ (UV, CAM).

\section{NMR Spectroscopy:}

${ }^{1}$ H NMR (500 MHz, $\left.\mathrm{CDCl}_{3}, 25{ }^{\circ} \mathrm{C}, \delta\right): 8.03-7.96(\mathrm{~m}, 2 \mathrm{H}), 7.42(\mathrm{~d}, J=7.9 \mathrm{~Hz}, 2 \mathrm{H}), 4.75(\mathrm{~s}, 2 \mathrm{H}), 3.91$ (q, $J=$ $1.1 \mathrm{~Hz}, 3 \mathrm{H}), 1.90(\mathrm{~s}, 1 \mathrm{H})$.

${ }^{13} \mathrm{C}\left\{{ }^{1} \mathrm{H}\right\}$ NMR $\left(126 \mathrm{MHz}, \mathrm{CDCl}_{3}, 25^{\circ} \mathrm{C}, \delta\right): 167.1,146.0,129.9,129.4,126.5,64.8,52.2$.

HRMS-EI(m/z) calc'd for $\mathrm{C}_{9} \mathrm{H}_{10} \mathrm{O}_{3}\left[\mathrm{MI}^{+}, 166.0625\right.$; found, 166.0624; deviation: -0.33 ppm.

${ }^{1} \mathrm{H}$ NMR of reaction mixture after step 1 and aqueous work-up with $\mathrm{CH}_{3} \mathrm{NO}_{2}$ as internal standard:

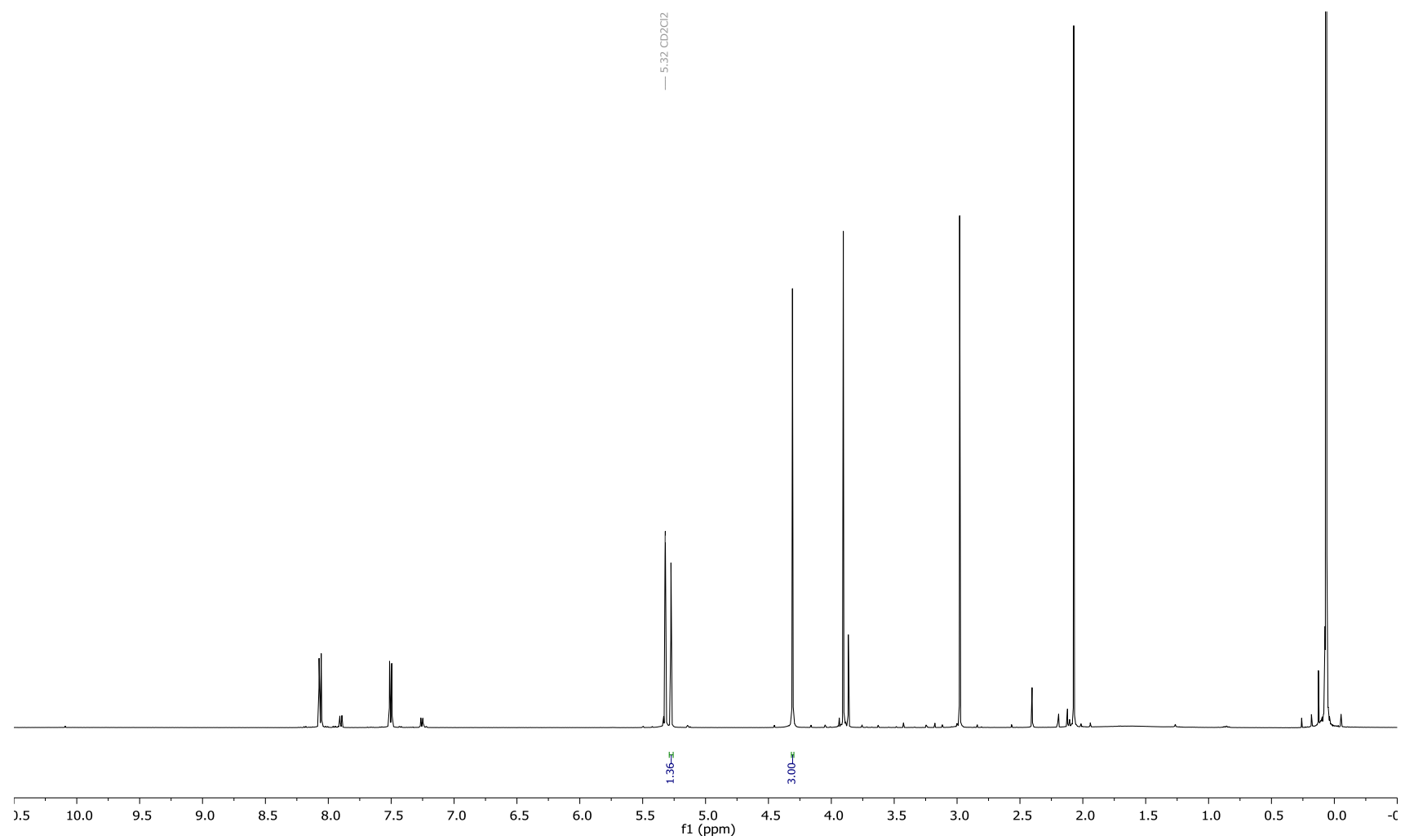


Ethyl-3-(5-bromo-2-fluorophenyl)-3-hydroxypropanoate (12)<smiles>CCOC(=O)CCc1cc(Br)ccc1F</smiles>

s11
1. CuOAc $(20 \mathrm{~mol} \%)$ TMSOAC (3 equiv) MsOOMs ( 1.5 equiv) $\operatorname{DCM}(0.2 \mathrm{M}), 12 \mathrm{~h}, 0^{\circ} \mathrm{C}$

2. HFIP: $\mathrm{H}_{2} \mathrm{O}(0.2 \mathrm{M})$ $7 \mathrm{~h}, 23^{\circ} \mathrm{C}$

$30 \%$<smiles>CCOC(=O)CC(O)c1cc(Br)ccc1F</smiles>

12

In an $\mathrm{N}_{2}$-filled glovebox, to a $4 \mathrm{~mL}$ vial containing a Teflon-coated magnetic stirring bar, CuOAc $(4.9 \mathrm{mg}$, $40 \mu \mathrm{mol}, 20 \mathrm{~mol} \%$ ), and ethyl 3-(5-bromo-2-fluorophenyl)propanoate (S11) (55.0 mg, $0.200 \mathrm{mmol}, 1.00$ equiv) were added DCM (1 mL, $c=0.2 \mathrm{M})$, TMSOAc $(90 \mu \mathrm{L}, 79 \mathrm{mg}, 0.60 \mathrm{mmol}, 3.0$ equiv), and solid bis(methanesulfonyl) peroxide $\left(57.0 \mathrm{mg}, 0.300 \mathrm{mmol}, 1.50\right.$ equiv) at $-10^{\circ} \mathrm{C}$. The vial was closed with a Teflon-lined screw cap and removed from the glovebox. The reaction mixture was stirred at $0{ }^{\circ} \mathrm{C}$ for $12 \mathrm{~h}$. Aqueous sodium sulfite solution (10\% (w:w), $1 \mathrm{~mL}$ ) was added to the reaction mixture. The resulting mixture was transferred to a separation funnel and extracted with EtOAc $(3 \times 20 \mathrm{~mL})$. The combined organic layers were washed with brine $(10 \mathrm{~mL})$, dried over $\mathrm{Na}_{2} \mathrm{SO}_{4}$, and concentrated under reduced pressure. To the residue was added HFIP: $\mathrm{H}_{2} \mathrm{O}(1: 1(\mathrm{v}: \mathrm{v}), 1 \mathrm{~mL}, \mathrm{c}=0.2 \mathrm{M})$. The reaction mixture was stirred for $7 \mathrm{~h}$ at $23^{\circ} \mathrm{C}$. The reaction mixture was concentrated under reduced pressure. The residue was purified by column chromatography on silica gel eluting with a solvent mixture of ethyl acetate:hexanes $(20: 80(\mathrm{v}: \mathrm{v}))$ to afford 18 $\mathrm{mg}$ of 12 as a colorless solid (30\% yield), and $10 \mathrm{mg}$ of mixture of the corresponding styrene and starting material in a ratio of $1.5: 1$.

$\mathbf{R}_{f}$ (ethyl acetate:hexanes, 30:70 (v:v)) $=0.28\left(\mathrm{UV}, \mathrm{KMnO}_{4}\right)$.

\section{NMR Spectroscopy:}

${ }^{1}$ H NMR $\left(500 \mathrm{MHz}, \mathrm{CDCl}_{3}, 25^{\circ} \mathrm{C}, \delta\right) .7 .69$ (dd, $\left.J=6.5,2.6 \mathrm{~Hz}, 1 \mathrm{H}\right), 7.37$ (ddd, $\left.J=8.7,4.6,2.6 \mathrm{~Hz}, 1 \mathrm{H}\right), 6.91$ (dd, $J=9.9,8.7 \mathrm{~Hz}, 1 \mathrm{H}$ ), 5.36 (dd, $J=9.5,3.0 \mathrm{~Hz}, 1 \mathrm{H}$ ), 4.20 (q, $J=7.2 \mathrm{~Hz}, 2 \mathrm{H}$ ), 3.61 (bs, $1 \mathrm{H}), 2.78$ (dd, $J=$ 16.6, 3.0 Hz, $1 \mathrm{H}), 2.65$ (dd, $J=16.7,9.4 \mathrm{~Hz}, 1 \mathrm{H}), 1.27$ (t, $J=7.1 \mathrm{~Hz}, 3 \mathrm{H})$.

${ }^{13} \mathrm{C}\left\{{ }^{1} \mathrm{H}\right\}$ NMR $\left(126 \mathrm{MHz}, \mathrm{CDCl}_{3}, 25^{\circ} \mathrm{C}, \delta\right): 172.4,158.5(\mathrm{~d}, J=246.3 \mathrm{~Hz}), 132.1(\mathrm{~d}, J=8.2 \mathrm{~Hz}), 131.8(\mathrm{~d}, J=$ $14.6 \mathrm{~Hz}), 130.5$ (d, $J=4.2 \mathrm{~Hz}), 117.3,117.08,64.3(\mathrm{~d}, J=2.5 \mathrm{~Hz}), 61.3,41.8,14.3$.

${ }^{19}$ F-NMR $\left(471 \mathrm{MHz}, \mathrm{CDCl}_{3}, 25^{\circ} \mathrm{C}, \delta\right):-121.23(\mathrm{dt}, J=10.6,5.5 \mathrm{~Hz})$.

HRMS-EI (m/z) calc'd for $\mathrm{C}_{11} \mathrm{H}_{12} \mathrm{O}_{3} \mathrm{BrF}[\mathrm{M}]^{+}$, 289.9950; found, 289.9948; deviation: -0.42 ppm.

${ }^{19} \mathrm{~F}$ NMR of reaction mixture after step 2: 
Desired product

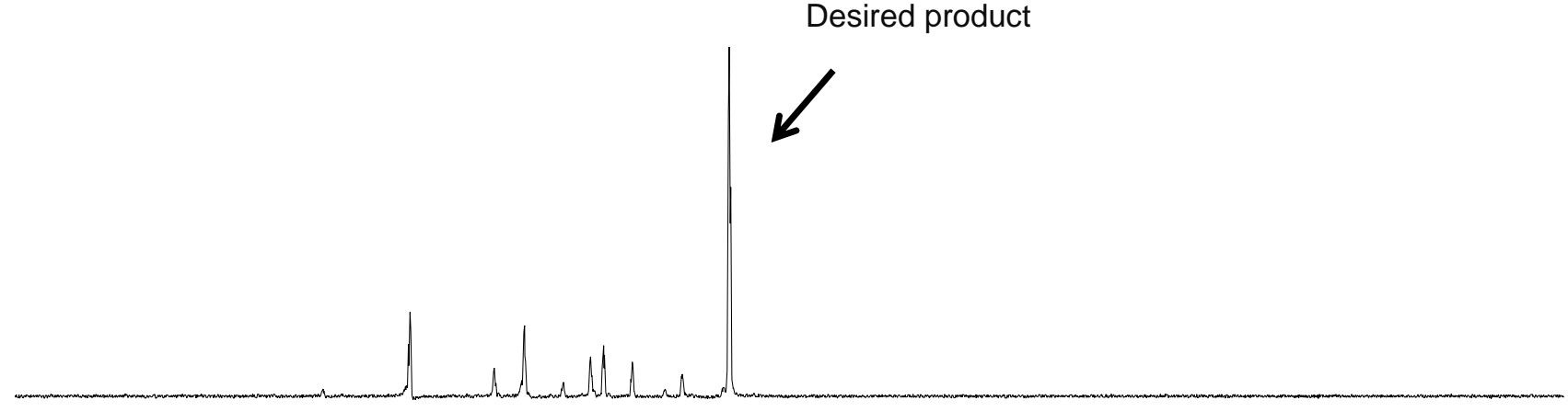

\begin{tabular}{|c|c|c|c|c|c|c|c|c|c|c|c|c|c|c|c|c|c|c|c|}
\hline-112 & -113 & -114 & -115 & -116 & -117 & -118 & -119 & -120 & -121 & $\begin{array}{c}-122 \\
\mathrm{f} 1(\mathrm{ppm})\end{array}$ & -123 & -124 & -125 & -126 & -127 & -128 & -129 & -130 & -131 \\
\hline
\end{tabular}

Methyl-3-hydroxy-3-(3-trifluoromethyl)phenyl) propanoate (13)

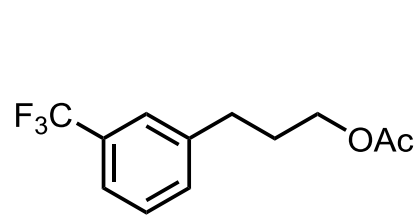

S12
1. CuOAc (20 mol\%) TMSOAC (3 equiv) MsOOMs ( 1.5 equiv) $\operatorname{DCM}(0.2 \mathrm{M}), 12 \mathrm{~h},-20^{\circ} \mathrm{C}$

2. HFIP: $\mathrm{H}_{2} \mathrm{O}(0.2 \mathrm{M})$ $24 \mathrm{~h}, 23^{\circ} \mathrm{C}$<smiles>CC(=O)OCCC(O)c1cccc(C(F)(F)F)c1</smiles>

13

In an $\mathrm{N}_{2}$-filled glovebox, to a $4 \mathrm{~mL}$ vial containing a Teflon-coated magnetic stirring bar, CuOAc $(4.9 \mathrm{mg}$, $40 \mu \mathrm{mol}, 20 \mathrm{~mol} \%$ ), and methyl 3-(3-(trifluoromethyl)phenyl)propanoate (S12) (43.0 mg, $0.200 \mathrm{mmol}, 1.00$ equiv) were added DCM $(1 \mathrm{~mL}, \mathrm{c}=0.2 \mathrm{M})$, TMSOAc $(90 \mu \mathrm{L}, 79 \mathrm{mg}, 0.60 \mathrm{mmol}, 3.0$ equiv), and solid bis(methanesulfonyl) peroxide $\left(57.0 \mathrm{mg}, 0.300 \mathrm{mmol}, 1.50\right.$ equiv) at $-20{ }^{\circ} \mathrm{C}$. The vial was closed with a Teflon-lined screw cap and removed from the glovebox. The reaction mixture was stirred at $-20^{\circ} \mathrm{C}$ for $12 \mathrm{~h}$. Aqueous sodium sulfite solution (10\% (w:w), $1 \mathrm{~mL}$ ) was added to the reaction mixture. The resulting mixture was transferred to a separation funnel and extracted with EtOAc $(3 \times 20 \mathrm{~mL})$. The combined organic layers were washed with brine $(10 \mathrm{~mL})$, dried over $\mathrm{Na}_{2} \mathrm{SO}_{4}$, and concentrated under reduced pressure. To the residue was added HFIP: $\mathrm{H}_{2} \mathrm{O}(1: 1(\mathrm{v}: \mathrm{v}), 1 \mathrm{~mL}, \mathrm{C}=0.2 \mathrm{M})$. The reaction mixture was stirred for $24 \mathrm{~h}$ at $23^{\circ} \mathrm{C}$. The reaction mixture was concentrated under reduced pressure. The residue was purified by column chromatography on silica gel eluting with a solvent mixture of ethyl acetate:hexanes (15:85 (v:v)) to afford $39 \mathrm{mg}$ of 13 as a colorless liquid (75\% yield). 
$\mathbf{R}_{\boldsymbol{f}}$ (ethyl acetate:hexanes, 30:70 (v:v))) $=0.29\left(\mathrm{UV}, \mathrm{KMnO}_{4}\right)$.

\section{NMR Spectroscopy:}

${ }^{1} \mathrm{H}$ NMR $\left(500 \mathrm{MHz}, \mathrm{CDCl}_{3}, 25^{\circ} \mathrm{C}, \delta\right) .7 .64(\mathrm{~s}, 1 \mathrm{H}), 7.55$ (d, J = 7.9 Hz, 2H), $7.47(\mathrm{t}, J=7.7 \mathrm{~Hz}, 1 \mathrm{H}), 4.85$ (t, J $=6.6 \mathrm{~Hz}, 1 \mathrm{H}), 4.41-4.34(\mathrm{~m}, 1 \mathrm{H}), 4.14(\mathrm{~m}, J=11.3,5.6,1.4 \mathrm{~Hz}, 1 \mathrm{H}), 2.07-2.01(\mathrm{~m}, 6 \mathrm{H})$.

${ }^{13} \mathrm{C}\left\{{ }^{1} \mathrm{H}\right\}$ NMR $\left(126 \mathrm{MHz}, \mathrm{CDCl}_{3}, 25^{\circ} \mathrm{C}, \delta\right): 171.5,145.1,131.0(\mathrm{~d}, J=32.3 \mathrm{~Hz}), 129.2(\mathrm{~d}, J=8.3 \mathrm{~Hz}), 124.6$ (d, $J=4.0 \mathrm{~Hz}$ ), 124.1 (q, $J=272: 4 \mathrm{~Hz}$ ), 122.7 (t, $J=3.8 \mathrm{~Hz}$ ), 70.8, 61.5, 38.3, 21.1.

${ }^{9}$ F-NMR $\left(471 \mathrm{MHz}, \mathrm{CDCl}_{3}, 25^{\circ} \mathrm{C}, \delta\right):-62.64(\mathrm{~s})$.

HRMS-ESI (m/z) calc'd for $\mathrm{C}_{12} \mathrm{H}_{13} \mathrm{O}_{3} \mathrm{~F}_{3}[\mathrm{M}+\mathrm{Na}]^{+}$, 285.0710; found, 285.0709; deviation: -0.42 ppm.

Hydroxylated phenylalanine derivative 14

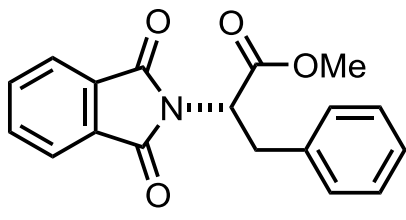

22
1. CuOAc $(20 \mathrm{~mol} \%)$ TMSOAc (3 equiv) MsOOMs ( 1.5 equiv) $\operatorname{DCM}(0.2 \mathrm{M}), 12 \mathrm{~h}, 23^{\circ} \mathrm{C}$

2. HFIP: $\mathrm{H}_{2} \mathrm{O}(0.2 \mathrm{M})$

$12 \mathrm{~h}, 23^{\circ} \mathrm{C}$

$82 \%$

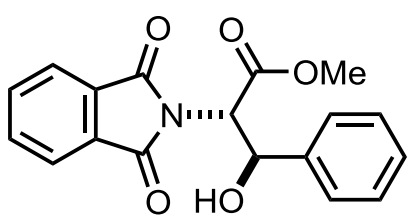

14

In an $\mathrm{N}_{2}$-filled glovebox, to a $4 \mathrm{~mL}$ vial containing a Teflon-coated magnetic stirring bar, CuOAc (4.9 mg, $40 \mu \mathrm{mol}, 20 \mathrm{~mol} \%$ ), and $\mathrm{N}$-phthaloyl-L-phenylalanine ester 22 (61.9 mg, $0.200 \mathrm{mmol}, 1.00$ equiv) were added DCM (1 mL, c = $0.2 \mathrm{M})$, TMSOAc $(90 \mu \mathrm{L}, 79 \mathrm{mg}, 0.60 \mathrm{mmol}, 3.0$ equiv), and solid bis(methanesulfonyl) peroxide $\left(57.0 \mathrm{mg}, 0.300 \mathrm{mmol}, 1.50\right.$ equiv) at $23^{\circ} \mathrm{C}$. The vial was closed with a Teflon-lined screw cap and removed from the glovebox. The reaction mixture was stirred at $23{ }^{\circ} \mathrm{C}$ for $12 \mathrm{~h}$. Aqueous sodium sulfite solution $(10 \%(w: w), 1 \mathrm{~mL})$ was added to the reaction mixture. The resulting mixture was transferred to a separation funnel and extracted with EtOAc $(3 \times 20 \mathrm{~mL})$. The combined organic layers were washed with brine $(10 \mathrm{~mL})$, dried over $\mathrm{Na}_{2} \mathrm{SO}_{4}$, and concentrated under reduced pressure. To the residue was added HFIP: $\mathrm{H}_{2} \mathrm{O}(1: 1(\mathrm{v}: \mathrm{v}), 1 \mathrm{~mL}, \mathrm{C}=0.2 \mathrm{M})$. The reaction mixture was stirred for $1 \mathrm{~h}$ at $23^{\circ} \mathrm{C}$. The reaction mixture was diluted with $\mathrm{H}_{2} \mathrm{O}(5 \mathrm{~mL})$ and EtOAc $(10 \mathrm{~mL})$, and the resulting mixture was transferred to a separation funnel. The layers were separated, and the aqueous layer was extracted with EtOAc $(2 \times 10 \mathrm{~mL})$. The combined organic layers were washed with brine $(10 \mathrm{~mL})$, dried over $\mathrm{Na}_{2} \mathrm{SO}_{4}$, and concentrated under reduced pressure. The residue was purified by column chromatography on silica gel eluting with a solvent mixture of ethyl acetate:hexanes (30:70 (v:v)) to afford $53 \mathrm{mg}$ of $\mathbf{1 4}$ as a colorless solid (82\% yield). The relative configuration was determined by $\mathrm{X}$-ray crystallography (See $\mathrm{X}$-ray crystallographic data).

$\mathbf{R}_{\boldsymbol{f}}$ (ethyl acetate:hexanes, 50:50 (v:v)) $=0.53\left(\mathrm{UV}, \mathrm{KMnO}_{4}\right)$.

\section{NMR Spectroscopy:}

${ }^{1} \mathbf{H}$ NMR $\left(500 \mathrm{MHz}, \mathrm{CDCl}_{3}, 25^{\circ} \mathrm{C}, \delta\right): \delta 7.78(\mathrm{dd}, J=5.5,3.1 \mathrm{~Hz}, 2 \mathrm{H}), 7.69(\mathrm{dd}, J=5.5,3.0 \mathrm{~Hz}, 2 \mathrm{H}), 7.36-$ $7.32(\mathrm{~m}, 2 \mathrm{H}), 7.29-7.24(\mathrm{~m}, 2 \mathrm{H}), 7.19-7.14(\mathrm{~m}, 1 \mathrm{H}), 5.71(\mathrm{dd}, J=10.4,4.7 \mathrm{~Hz}, 1 \mathrm{H}), 5.51(\mathrm{~d}, J=4.7 \mathrm{~Hz}$, 
$1 \mathrm{H}), 5.13(\mathrm{~d}, J=10.4 \mathrm{~Hz}, 1 \mathrm{H}), 3.86(\mathrm{~s}, 3 \mathrm{H})$.

${ }^{13} \mathrm{C}\left\{{ }^{1} \mathrm{H}\right\}$ NMR $\left(126 \mathrm{MHz}, \mathrm{CDCl}_{3}, 25{ }^{\circ} \mathrm{C}, \delta\right): 168.6,167.9,139.7,134.6,131.4,128.6,127.7,125.1,123.9$, 72.5, 59.4, 53.2.

HRMS-ESI (m/z) calc'd for $\mathrm{C}_{18} \mathrm{H}_{15} \mathrm{O}_{5} \mathrm{~N}[\mathrm{M}+\mathrm{Na}]^{+}$; 348.08422; found, 348.08424; deviation: +0.07 ppm.

Hydroxylated dextromethorphan derivative 15

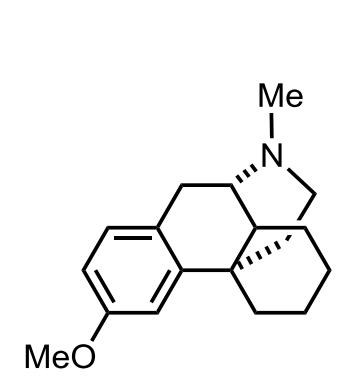

S13
1. TFA (1.1 equiv) $\operatorname{DCM}(0.2 \mathrm{M})$

2. CuOAc (20 mol\%) TMSOAC (3 equiv) MsOOMs ( 1.5 equiv) $\operatorname{DCM}(0.2 \mathrm{M}), 13 \mathrm{~h}, 23{ }^{\circ} \mathrm{C}$

3. $5 \% \mathrm{NaOMe}$ $\mathrm{MeOH}(0.2 \mathrm{M})$ $8 \mathrm{~h}, 23^{\circ} \mathrm{C}$

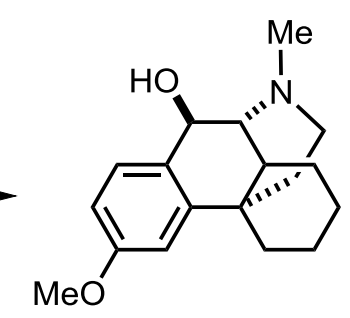

$53 \%$

15

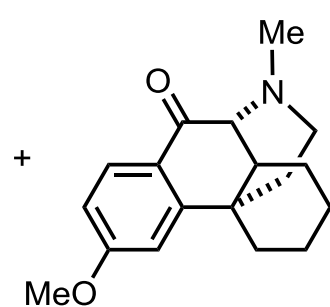

$10 \%$

To a $4 \mathrm{~mL}$ vial containing a Teflon-coated magnetic stirring bar were added dextromethorphan (S13) (83.0 mg, $0.305 \mathrm{mmol}, 1.00$ equiv) and DCM (1.5 mL). Trifluoroacetic acid (25.8 $\mu \mathrm{L}, 38.3 \mathrm{mg}, 0.330 \mathrm{mmol}$, 1.10 equiv) was added dropwise while stirring. The reaction mixture was stirred for 5 minutes at room temperature. Upon reaction completion the stir bar was taken out, and mixture was concentrated in vacuo and placed on vacuum overnight. The resulting colorless solid was reacted with. CuOAc $(7.5 \mathrm{mg}, 61 \mu \mathrm{mol}, 20$ mol\%), DCM (1.5 mL, c = $0.20 \mathrm{M})$, TMSOAc (138 $\mu \mathrm{L}, 121 \mathrm{mg}, 0.918 \mathrm{mmol}, 3.00$ equiv), and solid bis(methanesulfonyl) peroxide $\left(87.0 \mathrm{mg}, 0.459 \mathrm{mmol}, 1.50\right.$ equiv) at $23^{\circ} \mathrm{C}$. The vial was closed with a Teflonlined screw cap and removed from the glovebox. The reaction mixture was stirred at $23^{\circ} \mathrm{C}$ for $13 \mathrm{~h}$. Aqueous sodium sulfite solution $(10 \%(\mathrm{w} / \mathrm{w}), 1 \mathrm{~mL})$ was added to the reaction mixture followed by addition of saturated aqueous $\mathrm{NaHCO}_{3}$ solution $(1 \mathrm{~mL})$. The resulting mixture was transferred to a separation funnel and extracted with EtOAc $(3 \times 20 \mathrm{~mL})$. The combined organic layers were washed with brine $(10 \mathrm{~mL})$, dried over $\mathrm{Na}_{2} \mathrm{SO}_{4}$, and concentrated under reduced pressure. To the residue were added $\mathrm{NaOMe}$ in $\mathrm{MeOH}(5 \%$ (w:w); $1.5 \mathrm{~mL}, \mathrm{c}$ $=0.2 \mathrm{M})$. The reaction mixture was stirred for $8 \mathrm{~h}$ at $23^{\circ} \mathrm{C}$. The reaction mixture concentrated under reduced pressure. The residue was purified by column chromatography on basic $\mathrm{Al}_{2} \mathrm{O}_{3}$ Brockmann grade III, eluting with a solvent mixture of ethyl acetate:hexanes (40:60 (v:v)) to afford $47 \mathrm{mg}$ of $\mathbf{1 5}$ as a colorless solid (53\% yield) and $9 \mathrm{mg}$ of $15 \mathrm{~A}$ as a pale yellow solid (10\% yield).

\section{Data for major product 15A:}

$\mathbf{R}_{\boldsymbol{f}}$ (ethyl acetate:triethylamine, 10:0.3 (v:v)) $=0.12\left(\mathrm{UV}, \mathrm{KMnO}_{4}\right)$.

\section{NMR Spectroscopy:}

${ }^{1} \mathrm{H}$ NMR $\left(500 \mathrm{MHz}, \mathrm{CDCl}_{3}, 25^{\circ} \mathrm{C}, \delta\right) .7 .43(\mathrm{~d}, J=8.3 \mathrm{~Hz}, 1 \mathrm{H}), 6.84-6.78(\mathrm{~m}, 2 \mathrm{H}), 4.71(\mathrm{~s}, 1 \mathrm{H}), 3.81(\mathrm{~s}, 3 \mathrm{H})$, $2.90(\mathrm{~d}, J=2.8 \mathrm{~Hz}, 1 \mathrm{H}), 2.50(\mathrm{~s}, 3 \mathrm{H}), 2.43-2.32(\mathrm{~m}, 2 \mathrm{H}), 2.03-1.94(\mathrm{~m}, 1 \mathrm{H}), 1.91-1.84(\mathrm{~m}, 1 \mathrm{H}), 1.72(\mathrm{~m}$, 
$J=12.8,5.0 \mathrm{~Hz}, 1 \mathrm{H}), 1.63(\mathrm{~m}, J=6.6,2.3 \mathrm{~Hz}, 1 \mathrm{H}), 1.55-1.48(\mathrm{~m}, 2 \mathrm{H}), 1.44-1.21(\mathrm{~m}, 6 \mathrm{H})$.

${ }^{13} \mathrm{C}\left\{{ }^{1} \mathrm{H}\right\}$ NMR $\left(126 \mathrm{MHz}, \mathrm{CDCl}_{3}, 25{ }^{\circ} \mathrm{C}, \delta\right): 160.2,141.5,132.9,130.4,111.9,111.3,65.3,63.3,55.6,47.6$, 44.6, 43.3, 42.0, 38.1, 37.1, 27.3, 27.4, 22.6 .

HRMS-ESI (m/z) calc'd for $\mathrm{C}_{18} \mathrm{H}_{26} \mathrm{O}_{2} \mathrm{~N}[\mathrm{M}+\mathrm{H}]^{+}$, 288.1953; found, 288.1958; deviation: +1.61 ppm.

For COSY and NOESY see section: Spectral Data.

Relative stereochemistry was assigned based on ${ }^{1} \mathrm{H}$ NMR and NOESY $2 \mathrm{D}$ NMR methods.

\section{Data for ketone 15A:}

NMR Spectroscopy:

${ }^{1} \mathrm{H}$ NMR $\left(500 \mathrm{MHz}, \mathrm{CDCl}_{3}, 25^{\circ} \mathrm{C}, \delta\right) .8 .05(\mathrm{dd}, J=8.6,1.3 \mathrm{~Hz}, 1 \mathrm{H}), 6.85(\mathrm{~m}, J=8.7,2.5,1.3 \mathrm{~Hz}, 1 \mathrm{H}), 6.80$ (t, $J=1.7 \mathrm{~Hz}, 1 \mathrm{H}), 3.88(\mathrm{~d}, J=1.3 \mathrm{~Hz}, 3 \mathrm{H}), 3.02(\mathrm{~s}, 1 \mathrm{H}), 2.65(\mathrm{~d}, J=11.8 \mathrm{~Hz}, 1 \mathrm{H}), 2.37(\mathrm{~s}, 4 \mathrm{H}), 2.16-2.02(\mathrm{~m}$, $2 \mathrm{H}), 1.98-1.89(\mathrm{~m}, 1 \mathrm{H}), 1.65(\mathrm{~d}, J=13.1 \mathrm{~Hz}, 1 \mathrm{H}), 1.61-1.54(\mathrm{~m}, 1 \mathrm{H}), 1.52(\mathrm{~s}, 1 \mathrm{H}), 1.46-1.31(\mathrm{~m}, 2 \mathrm{H})$, $1.31-1.19(\mathrm{~m}, 2 \mathrm{H}), 1.17-1.07(\mathrm{~m}, 1 \mathrm{H})$.

HRMS-ESI (m/z) calc'd for $\mathrm{C}_{18} \mathrm{H}_{23} \mathrm{O}_{2} \mathrm{~N}[\mathrm{M}+\mathrm{H}]^{+}, 286.1799$; found, 286.1801; deviation: $+0.68 \mathrm{ppm}$

\section{4-Hydroxy (phenyl)methyl-3-propionyl-2-oxazolidinone 16}

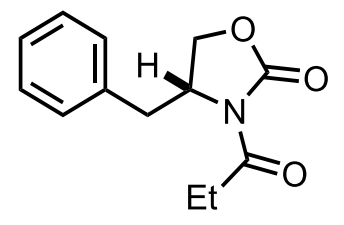

S14
1. CuOAc $(20 \mathrm{~mol} \%)$ TMSOAc (3 equiv) MsOOMs ( 1.8 equiv) $\operatorname{DCM}(0.2 \mathrm{M}), 12 \mathrm{~h}, 23^{\circ} \mathrm{C}$

2. HFIP: $\mathrm{H}_{2} \mathrm{O}(0.2 \mathrm{M})$ $12 \mathrm{~h}, 23^{\circ} \mathrm{C}$

$57 \%$<smiles>CCC(=O)N1C(=O)OC[C@H]1C(O)c1ccccc1</smiles>

16

In an $\mathrm{N}_{2}$-filled glovebox, to a $4 \mathrm{ml}$ vial containing a Teflon-coated magnetic stirring bar, CuOAc (9.8 mg, $80 \mu \mathrm{mol}, 20 \mathrm{~mol} \%$ ), and (R)-4-benzyl-3-propionyl-2-oxazolidinone (S14) (93.3 mg, $0.400 \mathrm{mmol}, 1.00$ equiv) were added DCM $(2 \mathrm{~mL}, \mathrm{c}=0.2 \mathrm{M})$, TMSOAc $(180.0 \mu \mathrm{L}, 158.7 \mathrm{mg}, 1.200 \mathrm{mmol}, 3.000$ equiv), and solid bis(methanesulfonyl) peroxide (137 mg, $0.720 \mathrm{mmol}, 1.80$ equiv) at $-20^{\circ} \mathrm{C}$. The vial was closed with a Teflonlined screw cap and removed from the glovebox. The reaction mixture was stirred at $23^{\circ} \mathrm{C}$ for $12 \mathrm{~h}$. Aqueous sodium sulfite solution $(10 \%(\mathrm{w}: \mathrm{w}), 1 \mathrm{~mL})$ was added to the reaction mixture. The resulting mixture was transferred to a separation funnel and extracted with EtOAc $(3 \times 20 \mathrm{~mL})$. The combined organic layers were washed with brine $(10 \mathrm{~mL})$, dried over $\mathrm{Na}_{2} \mathrm{SO}_{4}$, and concentrated under reduced pressure. To the residue was added HFIP: $\mathrm{H}_{2} \mathrm{O}(1: 1(\mathrm{v}: \mathrm{v}), 2 \mathrm{~mL}, \mathrm{c}=0.2 \mathrm{M})$. The reaction mixture was stirred for $12 \mathrm{~h}$ at $23^{\circ} \mathrm{C}$. The reaction mixture was concentrated under reduced pressure. The residue was purified by column chromatography on silica gel eluting with a solvent mixture of ethyl acetate:hexanes (40:70 (v:v)) to afford $57 \mathrm{mg}$ of 16 as a colorless liquid (57\% yield).

$\mathbf{R}_{\boldsymbol{f}}$ (ethyl acetate:hexanes, 50:50 (v:v)) $=0.22\left(\mathrm{UV}, \mathrm{KMnO}_{4}\right)$. 


\section{NMR Spectroscopy:}

${ }^{1}$ H NMR (500 MHz, $\left.\mathrm{CDCl}_{3}, 25{ }^{\circ} \mathrm{C}, \delta\right) .7 .42-7.31(\mathrm{~m}, 5 \mathrm{H}), 6.47(\mathrm{~s}, 1 \mathrm{H}), 5.71(\mathrm{~d}, J=7.0 \mathrm{~Hz}, 1 \mathrm{H}), 4.27-4.16$ $(\mathrm{m}, 2 \mathrm{H}), 4.14-4.06(\mathrm{~m}, 1 \mathrm{H}), 2.48(\mathrm{~m}, J=16.9,7.6 \mathrm{~Hz}, 1 \mathrm{H}), 2.38(\mathrm{~m}, J=16.9,7.5 \mathrm{~Hz}, 1 \mathrm{H}), 1.13(\mathrm{t}, J=7.5$ $\mathrm{Hz}, 3 \mathrm{H})$.

${ }^{13} \mathbf{C}\left\{{ }^{1} \mathrm{H}\right\}$ NMR $\left(126 \mathrm{MHz}, \mathrm{CDCl}_{3}, 25{ }^{\circ} \mathrm{C}, \delta\right): 173.5,159.6,135.8,129.3,129.2,127.1,76.9,66.4,56.4,27.6$, 8.9 .

HRMS-ESI (m/z) calc'd for $\mathrm{C}_{13} \mathrm{H}_{15} \mathrm{O}_{4} \mathrm{~N}[\mathrm{M}+\mathrm{Na}]^{+}$, 272.08930; found, 272.08933; deviation: +0.10 ppm.

Relative stereochemistry was assigned based on x-ray crystallographic analysis.

Additional note: The benzylic mesylate can be isolated by column chromatography with an eluent mixture of ethylacetate:hexane (40:70 (v:v)) as a pale yellow liquid (72\%) after step 1. See spectral data.

\section{Pyridyl substituted $\alpha, \beta$-epoxy carbonyl hydroxy analogue 17}

1. TFA (1.1 equiv) $\operatorname{DCM}(0.2 \mathrm{M})$<smiles>O=C1c2ccccc2CCC12OC2c1ccncc1</smiles>

S15
2. CuOAc $(20 \mathrm{~mol} \%)$ TMSOAC (3 equiv) MsOOMs (1.8 equiv) $\operatorname{DCM}(0.2 \mathrm{M}), 13 \mathrm{~h}, 23^{\circ} \mathrm{C}$

3. TFA (1 equiv) THF: $\mathrm{H}_{2} \mathrm{O}(0.2 \mathrm{M})$ $4 \mathrm{~h}, 23^{\circ} \mathrm{C}$

$65 \%$<smiles>O=C1c2ccccc2[C@@H](O)CC12OC2c1ccncc1</smiles>

$17 \mathrm{~A}$<smiles>O=C1c2ccccc2C(O)CC12OC2c1ccncc1</smiles>

17B

To a $4 \mathrm{~mL}$ vial containing a Teflon-coated magnetic stirring bar were added 3,4-dihydro-3'-(4-pyridyl)-1oxospiro(naphthalene-2(1H),2'-oxirane) (S15) (100 mg, $0.400 \mathrm{mmol}, 1$ equiv) and DCM (2.0 mL). Trifluoroacetic acid (36.8 $\mu \mathrm{L}, 54.8 \mathrm{mg}, 0.490 \mathrm{mmol}, 1.2$ equiv) was added dropwise while stirring. The reaction mixture was stirred for 5 minutes at room temperature. Upon reaction completion the stir bar was taken out, and mixture was concentrated in vacuo and placed on vacuum overnight. The resulting solid was reacted with. CuOAc (9.8 mg, $0.48 \mathrm{mmol}, 20 \mathrm{~mol} \%)$, DCM $(2.0 \mathrm{~mL}, \mathrm{c}=0.20 \mathrm{M})$, TMSOAc $(180 \mu \mathrm{L}, 159 \mathrm{mg}$, $1.20 \mathrm{mmol}, 3.0$ equiv), and solid bis(methanesulfonyl) peroxide $\left(114 \mathrm{mg}, 0.600 \mathrm{mmol}, 1.50\right.$ equiv) at $23^{\circ} \mathrm{C}$. The vial was closed with a Teflon-lined screw cap and removed from the glovebox. The reaction mixture was stirred at $23{ }^{\circ} \mathrm{C}$ for $13 \mathrm{~h}$. Aqueous sodium sulfite solution $(10 \%(\mathrm{w} / \mathrm{w}), 1 \mathrm{~mL})$ was added to the reaction mixture followed by addition of saturated aqueous $\mathrm{NaHCO}_{3}$ solution $(1 \mathrm{~mL})$. The resulting mixture was transferred to a separation funnel and extracted with EtOAc $(3 \times 20 \mathrm{~mL})$. The combined organic layers were washed with brine $(10 \mathrm{~mL})$, dried over $\mathrm{Na}_{2} \mathrm{SO}_{4}$, and concentrated under reduced pressure. To the residue was added TFA (30.6 $\mu \mathrm{L}, 45.6 \mathrm{mg}, 0.400 \mathrm{mmol}, 1$ equiv) in THF: $\mathrm{H}_{2} \mathrm{O}(1: 1$ (v:v), $2 \mathrm{~mL}, \mathrm{c}=0.2 \mathrm{M})$. The reaction mixture was stirred for $4 \mathrm{~h}$ at $23^{\circ} \mathrm{C}$. The reaction mixture concentrated under reduced pressure. The residue was purified by column chromatography on basic $\mathrm{Al}_{2} \mathrm{O}_{3}$ Brockmann grade III, eluting with a solvent mixture of ethyl acetate:hexanes (40:60 (v:v)) to afford $47 \mathrm{mg}$ of 17A as a colorless solid, $23 \mathrm{mg}$ of 17B as a 
colorless solid (65\% yield), and $28 \mathrm{mg}$ of starting material was recovered (29\%). The ratio of diastereomers was determined by integration of the $1 \mathrm{H}-\mathrm{NMR}$ resonances in $\mathrm{CDCl}_{3}$ of the benzylic $\mathrm{OH}$ groups (2:1). The relative configuration was determined by 2D-NOESY NMR spectroscopy.

\section{Data for major diastereomer 17A:}

$\mathbf{R}_{\boldsymbol{f}}$ (ethyl acetate:triethylamine, 10:0.3 (v:v) $=0.35\left(\mathrm{UV}, \mathrm{KMnO}_{4}\right)$.

\section{NMR Spectroscopy:}

${ }^{1}$ H NMR $\left(500 \mathrm{MHz}\right.$, DMSO- $\left.d_{6}, 25^{\circ} \mathrm{C}, \delta\right): 8.64(\mathrm{~d}, J=5.0 \mathrm{~Hz}, 2 \mathrm{H}), 7.95(\mathrm{dd}, J=7.8,1.4 \mathrm{~Hz}, 1 \mathrm{H}), 7.73(\mathrm{td}, J=$ 8.0, 7.4, 1.4 Hz, 1H), $7.68-7.63(\mathrm{~m}, 1 \mathrm{H}), 7.52-7.48(\mathrm{~m}, 1 \mathrm{H}), 7.47(\mathrm{~d}, J=5.9 \mathrm{~Hz}, 2 \mathrm{H}), 5.86(\mathrm{~d}, J=5.9 \mathrm{~Hz}$, $1 \mathrm{H}), 4.62$ (dt, $J=11.1,5.9,4.6 \mathrm{~Hz}, 1 \mathrm{H}), 4.33$ (bs, $1 \mathrm{H}$ ), 2.42 (t, $J=12.8,11.1 \mathrm{~Hz}, 1 \mathrm{H}), 1.84$ (dd, J = 12.8, 4.6 $\mathrm{Hz}, 1 \mathrm{H})$.

${ }^{13} \mathrm{C}\left\{{ }^{1} \mathrm{H}\right\}$ NMR (126 MHz, DMSO- $\left.d_{6}, 25^{\circ} \mathrm{C}, \delta\right): 192.1,149.4,147.6,143.1,134.5,130.4,127.7,126.4,126.3$, $121.9,64.1,62.4,61.9,34.9$.

HRMS-ESI (m/z) calc'd for $\mathrm{C}_{16} \mathrm{H}_{14} \mathrm{O}_{3} \mathrm{~N}[\mathrm{M}+\mathrm{H}]^{+}$, 268.0966; found, 268.0968; deviation: +0.74 ppm.

$J$-coupling and NOE analysis:

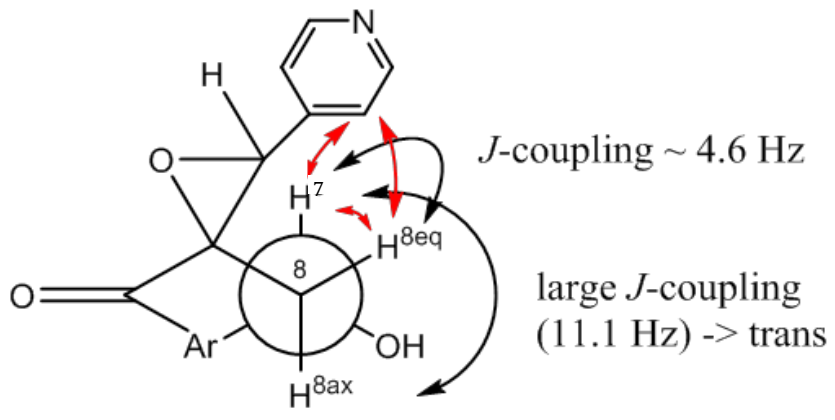

For COSY and NOESY see Supporting Information: Spectral Data

Relative stereochemistry was assigned based on 1H NMR and NOESY 2D NMR methods.

\section{Data for minor diastereomer 17B:}

$\mathbf{R}_{\boldsymbol{f}}$ (ethyl acetate:triethylamine, 10:0.3 (v:v) $=0.28\left(\mathrm{UV}, \mathrm{KMnO}_{4}\right)$.

\section{NMR Spectroscopy:}

${ }^{1}$ H NMR (500 MHz, DMSO, $\left.25^{\circ} \mathrm{C}, \delta\right): 8.61-8.57(\mathrm{~m}, 2 \mathrm{H}), 7.95$ (dd, $\left.J=8.1,1.4 \mathrm{~Hz}, 1 \mathrm{H}\right), 7.72(\mathrm{td}, J=7.5,1.4$ $\mathrm{Hz}, 1 \mathrm{H}), 7.55-7.51(\mathrm{~m}, 2 \mathrm{H}), 7.36-7.31(\mathrm{~m}, 2 \mathrm{H}), 5.38(\mathrm{~d}, J=5.8 \mathrm{~Hz}, 1 \mathrm{H}), 4.82(\mathrm{td}, J=5.6,3.5 \mathrm{~Hz}, 1 \mathrm{H}), 4.47$ (bs, $1 \mathrm{H}), 2.40$ (dd, $J=13.9,3.5 \mathrm{~Hz}, 1 \mathrm{H}), 1.85$ (dd, $J=13.9,5.4 \mathrm{~Hz}, 1 \mathrm{H})$.

${ }^{13} \mathrm{C}\left\{{ }^{1} \mathrm{H}\right\}$ NMR (126 MHz, DMSO, $\left.25^{\circ} \mathrm{C}, \delta\right): 192.0,149.2,145.4,143.5,134.8,131.1,128.6,128.40,126.6$, $122.2,65.4,62.3,61.7,32.7$.

HRMS-ESI (m/z) calc'd for $\mathrm{C}_{16} \mathrm{H}_{14} \mathrm{O}_{3} \mathrm{~N}[\mathrm{M}+\mathrm{H}]^{+}, 268.0965$; found, 268.0968; deviation: +1.23 ppm J-coupling and NOE analysis. 


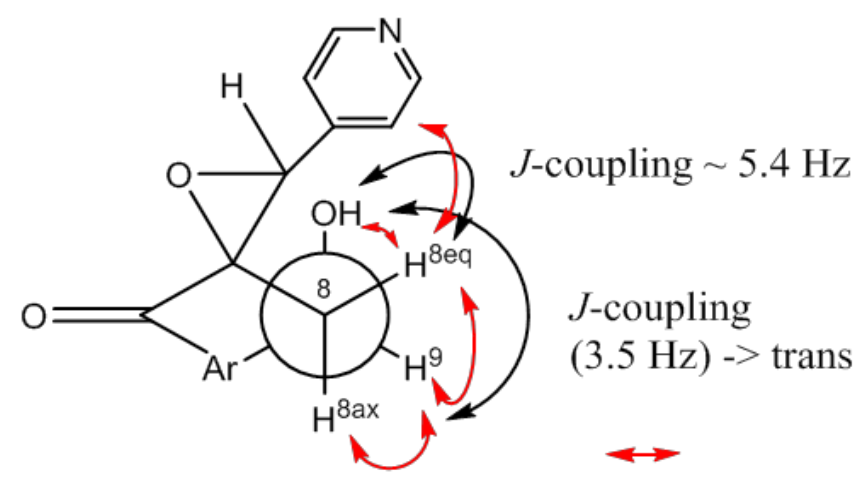

For COSY and NOESY see Supporting Information: Spectral Data

Stereochemistry was assigned based on ${ }^{1} \mathrm{H}$ NMR, COSY, and NOESY 2D NMR methods.

1-(4-(1H-pyrazol-1-yl)phenyl)ethan-1-ol (18)

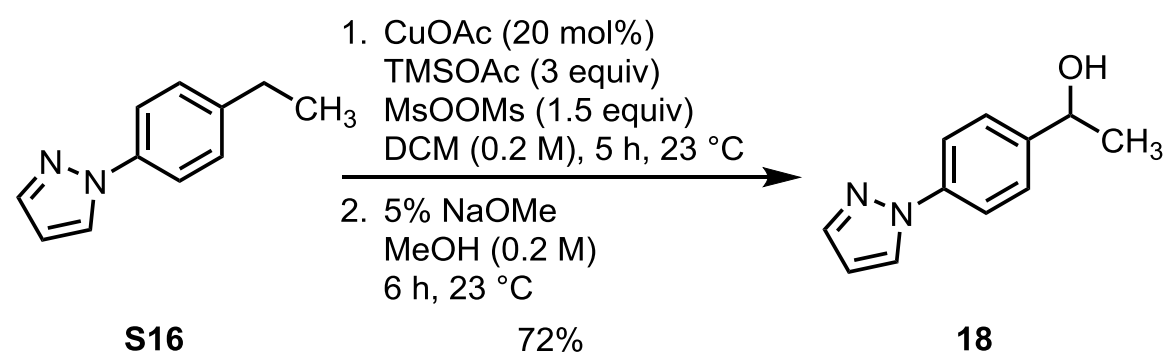

In an $\mathrm{N}_{2}$-filled glovebox, to a $4 \mathrm{~mL}$ vial containing a Teflon-coated magnetic stirring bar, CuOAc (4.9 mg, 40 $\mu \mathrm{mol}, 20 \mathrm{~mol} \%$ ), and 1-(4-ethylphenyl)-1H-pyrazole (S16) (34.5 mg, $0.200 \mathrm{mmol}, 1.00$ equiv) were added DCM (1 mL, c = $0.2 \mathrm{M})$, TMSOAc $(90 \mu \mathrm{L}, 79 \mathrm{mg}, 0.60 \mathrm{mmol}, 3.0$ equiv), and solid bis(methanesulfonyl) peroxide (57.0 mg, $0.300 \mathrm{mmol}, 1.50$ equiv) at $-30^{\circ} \mathrm{C}$. The vial was closed with a Teflon-lined screw cap and removed from the glovebox. The reaction mixture was stirred at $23{ }^{\circ} \mathrm{C}$ for $5 \mathrm{~h}$. Aqueous sodium sulfite solution $(10 \%(\mathrm{w} / \mathrm{w}), 1 \mathrm{~mL})$ was added to the reaction mixture. The resulting mixture was transferred to a separation funnel and extracted with EtOAc $(3 \times 20 \mathrm{~mL})$. The combined organic layers were washed with brine $\left(10 \mathrm{~mL}\right.$ ), dried over $\mathrm{Na}_{2} \mathrm{SO}_{4}$, and concentrated under reduced pressure. To the residue were added $\mathrm{NaOMe}$ in $\mathrm{MeOH}(5 \%(\mathrm{w}: \mathrm{w}) ; 1 \mathrm{~mL}, \mathrm{c}=0.2 \mathrm{M})$. The reaction mixture was stirred for $6 \mathrm{~h}$ at $23^{\circ} \mathrm{C}$. The reaction mixture was diluted with $\mathrm{H}_{2} \mathrm{O}(5 \mathrm{~mL})$ and EtOAc $(10 \mathrm{~mL})$, and the resulting mixture was transferred to a separation funnel. The layers were separated, and the aqueous layer was extracted with EtOAc $(2 \times 10 \mathrm{~mL})$. The combined organic layers were washed with brine $(10 \mathrm{~mL})$, dried over $\mathrm{Na}_{2} \mathrm{SO}_{4}$, and concentrated under reduced pressure. The residue was purified by column chromatography on silica gel eluting with a solvent mixture of ethyl acetate:pentane (20:80 (v:v)) to afford $27 \mathrm{mg} 18$ as a pale yellow solid $(72 \%$ yield).

$\mathbf{R}_{f}$ (ethyl acetate:pentane, 50:50 (v:v)) $=0.35\left(\mathrm{UV}, \mathrm{KMnO}_{4}\right)$.

\section{NMR Spectroscopy:}

${ }^{1} \mathrm{H}$ NMR $\left(500 \mathrm{MHz}, \mathrm{CDCl}_{3}, 25^{\circ} \mathrm{C}, \delta\right): 7.91(\mathrm{~d}, J=2.5 \mathrm{~Hz}, 1 \mathrm{H}), 7.72(\mathrm{~d}, J=1.8 \mathrm{~Hz}, 1 \mathrm{H}), 7.68-7.63(\mathrm{~m}, 2 \mathrm{H})$, $7.48-7.43(\mathrm{~m}, 2 \mathrm{H}), 6.46(\mathrm{t}, J=2.2 \mathrm{~Hz}, 1 \mathrm{H}), 4.94(\mathrm{q}, J=6.5 \mathrm{~Hz}, 1 \mathrm{H}), 2.06(\mathrm{~s}, 2 \mathrm{H}), 1.52(\mathrm{~d}, J=6.5 \mathrm{~Hz}, 3 \mathrm{H})$. 
${ }^{13} \mathrm{C}\left\{{ }^{1} \mathrm{H}\right\}$ NMR $\left(126 \mathrm{MHz}, \mathrm{CDCl}_{3}, 25^{\circ} \mathrm{C}, \delta\right): 144.3,141.2,139.5,126.9,126.6,119.5,107.7,69.9,25.4$.

HRMS-ESI(m/z) calc'd for [M] ${ }^{+}, \mathrm{C}_{11} \mathrm{H}_{12} \mathrm{~N}_{2} \mathrm{O}_{1}, 188.0945$; found, 188.0944; deviation: -0.73 ppm.

5-(1-hydroxyethyl)thiophene-2-carbaldehyde (19)

1. CuOAc $(20 \mathrm{~mol} \%)$

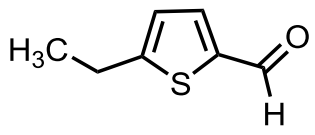
TMSOAC (3 equiv) MsOOMs (1.5 equiv) $\underset{\mathrm{DCM}(0.2 \mathrm{M}), 10 \mathrm{~h}, 23^{\circ} \mathrm{C}}{\longrightarrow}$

2. $5 \% \mathrm{NaOMe}$ $\mathrm{MeOH}(0.2 \mathrm{M})$ $8 \mathrm{~h}, 23^{\circ} \mathrm{C}$

S17 $67 \%$

19

In an $\mathrm{N}_{2}$-filled glovebox, to a $4 \mathrm{~mL}$ vial containing a Teflon-coated magnetic stirring bar, CuOAc (4.9 mg, 40 $\mu \mathrm{mol}, 20 \mathrm{~mol} \%$ ), and 5-ethyl-2-thiophencarboxaldehyde (S17) (28.0 mg, $0.200 \mathrm{mmol}, 1.00$ equiv) were added DCM (1 mL, c = $0.2 \mathrm{M})$, TMSOAc $(90 \mu \mathrm{L}, 79 \mathrm{mg}, 0.60 \mathrm{mmol}, 3.0$ equiv), and solid bis(methanesulfonyl) peroxide (57.0 mg, $0.300 \mathrm{mmol}, 1.50$ equiv) at $-20^{\circ} \mathrm{C}$. The vial was closed with a Teflon-lined screw cap and removed from the glovebox. The reaction mixture was stirred at $23{ }^{\circ} \mathrm{C}$ for $10 \mathrm{~h}$. Aqueous sodium sulfite solution $(10 \%(w / w), 1 \mathrm{~mL})$ was added to the reaction mixture. The resulting mixture was transferred to a separation funnel and extracted with EtOAc $(3 \times 20 \mathrm{~mL})$. The combined organic layers were washed with brine $\left(10 \mathrm{~mL}\right.$ ), dried over $\mathrm{Na}_{2} \mathrm{SO}_{4}$, and concentrated under reduced pressure. To the residue were added $\mathrm{NaOMe}$ in $\mathrm{MeOH}(5 \%(\mathrm{w}: \mathrm{w}) ; 1 \mathrm{~mL}, \mathrm{c}=0.2 \mathrm{M})$. The reaction mixture was stirred for $8 \mathrm{~h}$ at $23^{\circ} \mathrm{C}$. The reaction mixture was diluted with $\mathrm{H}_{2} \mathrm{O}(5 \mathrm{~mL})$ and EtOAc $(10 \mathrm{~mL})$, and the resulting mixture was transferred to a separation funnel. The layers were separated, and the aqueous layer was extracted with EtOAc $(2 \times 10 \mathrm{~mL})$. The combined organic layers were washed with brine $(10 \mathrm{~mL})$, dried over $\mathrm{Na}_{2} \mathrm{SO}_{4}$, and concentrated under reduced pressure. The residue was purified by column chromatography on silica gel eluting with a solvent mixture of ethyl acetate:pentane (20:80 (v:v)) to afford $21 \mathrm{mg} 19$ as a colorless liquid (67\% yield).

$\mathbf{R}_{\boldsymbol{f}}$ (ethyl acetate:pentane, $\left.30: 70(\mathrm{v}: \mathrm{v})\right)=0.16\left(\mathrm{UV}, \mathrm{KMnO}_{4}\right)$.

\section{NMR Spectroscopy:}

${ }^{1}$ H NMR $\left(500 \mathrm{MHz}, \mathrm{CDCl}_{3}, 25^{\circ} \mathrm{C}, \delta\right): 9.86(\mathrm{~s}, 1 \mathrm{H}), 7.65(\mathrm{~d}, \mathrm{~J}=3.8 \mathrm{~Hz}, 1 \mathrm{H}), 7.07$ (dd, J = 3.8, $\left.0.9 \mathrm{~Hz}, 1 \mathrm{H}\right)$, $5.16(\mathrm{qd}, \mathrm{J}=6.4,0.9 \mathrm{~Hz}, 1 \mathrm{H}), 1.92(\mathrm{~s}, 1 \mathrm{H}), 1.62(\mathrm{~d}, \mathrm{~J}=6.5 \mathrm{~Hz}, 3 \mathrm{H})$.

${ }^{13} \mathrm{C}\left\{{ }^{1} \mathrm{H}\right\}$ NMR $\left(126 \mathrm{MHz}, \mathrm{CDCl}_{3}, 25^{\circ} \mathrm{C}, \delta\right): 183.2,161.1,142.5,136.7,124.2,66.74,25.57$.

HRMS-ESI(m/z) calc'd for [M] ${ }^{+}, \mathrm{C}_{8} \mathrm{H}_{8} \mathrm{O}_{3}, 157.03180$; found, 157.03178; deviation: -0.14 ppm. 
7-hydroxy-6,7-dihydrobenzofuran-4(5H)-one (20)

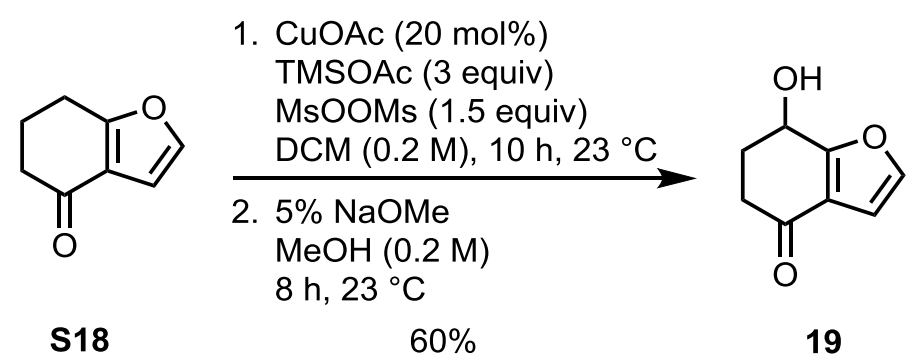

In an $\mathrm{N}_{2}$-filled glovebox, to a $4 \mathrm{~mL}$ vial containing a Teflon-coated magnetic stirring bar, CuOAc (4.9 mg, 40 $\mu \mathrm{mol}, 20 \mathrm{~mol} \%$ ), and 6,7-Dihydro-4(5H)-benzofuranon (S18) (27.3 mg, $0.200 \mathrm{mmol}, 1.00$ equiv) were added DCM (1 mL, c = $0.2 \mathrm{M})$, TMSOAc $(90 \mu \mathrm{L}, 79 \mathrm{mg}, 0.60 \mathrm{mmol}, 3.0$ equiv), and solid bis(methanesulfonyl) peroxide (57.0 mg, $0.300 \mathrm{mmol}, 1.50$ equiv) at $-20^{\circ} \mathrm{C}$. The vial was closed with a Teflon-lined screw cap and removed from the glovebox. The reaction mixture was stirred at $23{ }^{\circ} \mathrm{C}$ for $10 \mathrm{~h}$. Aqueous sodium sulfite solution $(10 \%(w / w), 1 \mathrm{~mL})$ was added to the reaction mixture. The resulting mixture was transferred to a separation funnel and extracted with EtOAc $(3 \times 20 \mathrm{~mL})$. The combined organic layers were washed with brine $(10 \mathrm{~mL})$, dried over $\mathrm{Na}_{2} \mathrm{SO}_{4}$, and concentrated under reduced pressure. To the residue were added $\mathrm{NaOMe}$ in $\mathrm{MeOH}(5 \%(\mathrm{w}: \mathrm{w}) ; 1 \mathrm{~mL}, \mathrm{c}=0.2 \mathrm{M})$. The reaction mixture was stirred for $8 \mathrm{~h}$ at $23^{\circ} \mathrm{C}$. The reaction mixture was diluted with $\mathrm{H}_{2} \mathrm{O}(5 \mathrm{~mL})$ and EtOAc $(10 \mathrm{~mL})$, and the resulting mixture was transferred to a separation funnel. The layers were separated, and the aqueous layer was extracted with EtOAc $(2 \times 10 \mathrm{~mL})$. The combined organic layers were washed with brine $(10 \mathrm{~mL})$, dried over $\mathrm{Na}_{2} \mathrm{SO}_{4}$, and concentrated under reduced pressure. The residue was purified by column chromatography on silica gel eluting with a solvent mixture of ethyl acetate:pentane (30:70 (v:v)) to afford $18 \mathrm{mg} 20$ as a pale yellow liquid (60\% yield).

$\mathbf{R}_{f}$ (ethyl acetate:pentane, 40:60 (v:v)) $=0.15\left(\mathrm{UV}, \mathrm{KMnO}_{4}\right)$.

\section{NMR Spectroscopy:}

${ }^{1} \mathrm{H}$ NMR $\left(500 \mathrm{MHz}, \mathrm{CDCl}_{3},-40{ }^{\circ} \mathrm{C}, \delta\right): 7.42(\mathrm{~d}, J=2.0 \mathrm{~Hz}, 1 \mathrm{H}), 6.66(\mathrm{~d}, J=2.0 \mathrm{~Hz}, 1 \mathrm{H}), 5.07(\mathrm{dd}, J=6.6,4.7$ $\mathrm{Hz}, 1 \mathrm{H}$ ), $3.50-3.00$ (bs, $1 \mathrm{H}$ ), 2.79 (ddd, $J=17.0,8.0,4.5 \mathrm{~Hz}, 1 \mathrm{H}$ ), 2.52 (ddd, $J=17.0,8.4,4.5 \mathrm{~Hz}, 1 \mathrm{H}$ ), $2.44(\mathrm{~m}, J=13.3,8.3,4.6 \mathrm{~Hz}, 1 \mathrm{H}), 2.20(\mathrm{~m}, J=13.3,8.5,6.6,4.4 \mathrm{~Hz}, 1 \mathrm{H})$.

${ }^{13} \mathrm{C}\left\{{ }^{1} \mathrm{H}\right\}$ NMR $\left(126 \mathrm{MHz}, \mathrm{CDCl}_{3}, 25^{\circ} \mathrm{C}, \delta\right): 194.2,165.3,144.1,121.5,106.7,62.7,35.17,32.09$.

HRMS-ESI(m/z) calc'd for $\left[\mathrm{M}^{+}, \mathrm{C}_{8} \mathrm{H}_{8} \mathrm{O}_{3}, 152.0469\right.$; found, 152.0468; deviation: $-0.69 \mathrm{ppm}$. 
Hydroxylated celecoxib derivative 21<smiles>Cc1ccc(-c2cc(C(F)(F)F)nn2-c2ccc(S(N)(=O)=O)cc2)cc1</smiles>

S19
1. CuOAc (20 mol\%)

TMSOAC (3 equiv) MsOOMs (1.5 equiv) $\operatorname{DCM}(0.2 \mathrm{M}), 10 \mathrm{~h}, 23^{\circ} \mathrm{C}$

2. HFIP: $\mathrm{H}_{2} \mathrm{O}(0.1 \mathrm{M})$

$24 \mathrm{~h}, 30^{\circ} \mathrm{C}$<smiles>NS(=O)(=O)c1ccc(-n2nc(C(F)(F)F)cc2-c2ccc(CO)cc2)cc1</smiles>

21

In an $\mathrm{N}_{2}$-filled glovebox, to a $4 \mathrm{~mL}$ vial containing a Teflon-coated magnetic stirring bar, CuOAc (3.9 mg, 31 $\mu \mathrm{mol}, 20 \mathrm{~mol} \%$ ), and Celecoxib (S19) $(60.0 \mathrm{mg}, 0.157 \mathrm{mmol}, 1.00$ equiv) were added DCM (0.8 $\mathrm{mL}, \mathrm{c}=$ $0.2 \mathrm{M}$ ), TMSOAc $(71 \mu \mathrm{L}, 62 \mathrm{mg}, 0.47 \mathrm{mmol}, 3.0$ equiv), and solid bis(methanesulfonyl) peroxide (44.8 $\mathrm{mg}$, $0.236 \mathrm{mmol}, 1.50$ equiv) at $-10^{\circ} \mathrm{C}$. The vial was closed with a Teflon-lined screw cap and removed from the glovebox. The reaction mixture was stirred at $23^{\circ} \mathrm{C}$ for $10 \mathrm{~h}$. Aqueous sodium sulfite solution (10\% (w/w), 1 $\mathrm{mL}$ ) was added to the reaction mixture. The resulting mixture was transferred to a separation funnel and extracted with EtOAc $(3 \times 20 \mathrm{~mL})$. The combined organic layers were washed with brine $(10 \mathrm{~mL})$, dried over $\mathrm{Na}_{2} \mathrm{SO}_{4}$, and concentrated under reduced pressure. To the residue was added HFIP: $\mathrm{H}_{2} \mathrm{O}(1: 1$ (v:v), $1.57 \mathrm{~mL}$, $\mathrm{C}=0.10 \mathrm{M}$ ). The reaction mixture was stirred for $24 \mathrm{~h}$ at $30^{\circ} \mathrm{C}$. The reaction mixture was concentrated under reduced pressure. The residue was purified by column chromatography on silica gel eluting with a solvent mixture of ethyl acetate:pentane (50:50 (v:v)) to afford $38 \mathrm{mg} 21$ as a colorless solid (61\% yield).

$\mathbf{R}_{\boldsymbol{f}}$ (ethyl acetate:pentane, 60:40 (v:v)) $=0.22\left(\mathrm{UV}, \mathrm{KMnO}_{4}\right)$.

\section{NMR Spectroscopy:}

${ }^{1} \mathrm{H}$ NMR $\left(500 \mathrm{MHz}, \mathrm{CD}_{2} \mathrm{Cl}_{2}, 25^{\circ} \mathrm{C}, \delta\right): 7.93-7.87(\mathrm{~m}, 2 \mathrm{H}), 7.51-7.45(\mathrm{~m}, 2 \mathrm{H}), 7.45(\mathrm{~s}, 2 \mathrm{H}), 7.28-7.20(\mathrm{~m}$, 2H), $6.81(\mathrm{~s}, 1 \mathrm{H}), 4.96(\mathrm{~s}, 2 \mathrm{H}), 4.71(\mathrm{~d}, J=4.3 \mathrm{~Hz}, 2 \mathrm{H}), 1.92(\mathrm{t}, J=5.7 \mathrm{~Hz}, 1 \mathrm{H})$

${ }^{13} \mathrm{C}\left\{{ }^{1} \mathrm{H}\right\}$ NMR $\left(126 \mathrm{MHz}, \mathrm{CD}_{2} \mathrm{Cl}_{2}, 25^{\circ} \mathrm{C}, \delta\right): 145.7,144.3$ (q, $\left.J=38.5 \mathrm{~Hz}\right), 143.3,142.9,142.3,129.6,128.2$, $128.0,127.8,126.2,121.8$ (q, $J=268.9 \mathrm{~Hz}), 107.0,64.84$.

${ }^{19}$ F-NMR $\left(471 \mathrm{MHz}, \mathrm{CD}_{2} \mathrm{Cl}_{2}, 25^{\circ} \mathrm{C}, \delta\right):-62.48$.

HRMS-ESI(m/z) calc'd for [M-H] ${ }^{-}, \mathrm{C}_{17} \mathrm{H}_{13} \mathrm{~F}_{3} \mathrm{~N}_{3} \mathrm{O}_{3} \mathrm{~S}_{1}, 396.0633$; found, 396.0635; deviation: +0.47 ppm. 
4,4'-Difluorobenzhydrol (S20A) and 4,4'-difluorbenzophenone (S20B)

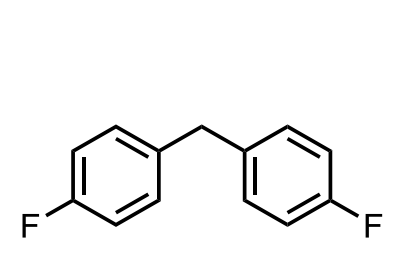

S20

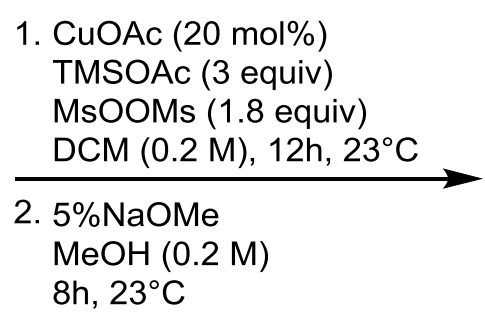

$8 \mathrm{~h}, 23^{\circ} \mathrm{C}$

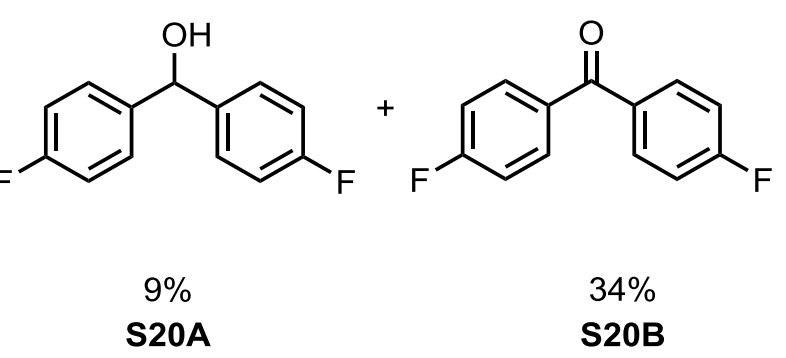

In an $\mathrm{N}_{2}$-filled glovebox, to a $4 \mathrm{~mL}$ vial containing a Teflon-coated magnetic stirring bar, CuOAc (4.9 mg, $40 \mathrm{\mu mol}, 20 \mathrm{~mol} \%$ ), and 4,4'-difluordiphenylmethane (S20) $(40.9 \mathrm{mg}, 0.200 \mathrm{mmol}, 1.00$ equiv) were added DCM ( $1 \mathrm{~mL}, c=0.2 \mathrm{M})$, TMSOAc $(90 \mu \mathrm{L}, 79 \mathrm{mg}, 0.60 \mathrm{mmol}, 3.0$ equiv), and solid bis(methanesulfonyl) peroxide $\left(57.0 \mathrm{mg}, 0.300 \mathrm{mmol}, 1.50\right.$ equiv) at $23^{\circ} \mathrm{C}$. The vial was closed with a Teflon-lined screw cap and removed from the glovebox. The reaction mixture was stirred at $23{ }^{\circ} \mathrm{C}$ for $12 \mathrm{~h}$. Aqueous sodium sulfite solution $(10 \%(\mathrm{w}: \mathrm{w}), 1 \mathrm{~mL})$ was added to the reaction mixture. The resulting mixture was transferred to a separation funnel and extracted with EtOAc $(3 \times 20 \mathrm{~mL})$. The combined organic layers were washed with brine $(10 \mathrm{~mL})$, dried over $\mathrm{Na}_{2} \mathrm{SO}_{4}$, and concentrated under reduced pressure. To the residue were added $\mathrm{NaOMe}$ in $\mathrm{MeOH}(5 \%(\mathrm{w}: \mathrm{w}) ; 1.5 \mathrm{~mL}, \mathrm{c}=0.2 \mathrm{M})$. The reaction mixture was stirred for $12 \mathrm{~h}$ at $23^{\circ} \mathrm{C}$. The reaction mixture was concentrated under reduced pressure. The residue was purified by column chromatography on silica gel eluting with a solvent mixture of ethyl acetate:hexanes $(20: 80(\mathrm{v}: \mathrm{v}))$ to afford 4 $\mathrm{mg}$ of the title compound $\mathbf{S 2 0 A}$ as a colorless solid (9\%), and $15 \mathrm{mg}$ of title compound S20B as a colorless solid (34\% yield).

$\mathbf{R}_{\boldsymbol{f}}$ (ethyl acetate:hexanes, 30:70 (v:v) $=0.54\left(\mathrm{UV}, \mathrm{KMnO}_{4}\right)$

4,4`-Difluorobenzhydrol (S20A):

\section{NMR Spectroscopy:}

${ }^{1} \mathrm{H}$ NMR $\left.\left(500 \mathrm{MHz}, \mathrm{CDCl}_{3}, 25^{\circ} \mathrm{C}, \delta\right)\right): 7.35-7.30(\mathrm{~m}, 4 \mathrm{H}), 7.06-7.00(\mathrm{~m}, 4 \mathrm{H}), 5.82(\mathrm{~s}, 1 \mathrm{H}), 2.20(\mathrm{bs}, 1 \mathrm{H})$.

${ }^{13} \mathrm{C}\left\{{ }^{1} \mathrm{H}\right\}$ NMR $\left(126 \mathrm{MHz}, \mathrm{CDCl}_{3}, 25^{\circ} \mathrm{C}, \delta\right): 162.4(\mathrm{~d}, J=246.2 \mathrm{~Hz}), 139.6(\mathrm{~d}, J=3.0 \mathrm{~Hz}), 128.3(\mathrm{~d}, J=8.3$ $\mathrm{Hz}), 115.6(\mathrm{~d}, J=21.1 \mathrm{~Hz}), 75.1$.

${ }^{19} \mathrm{~F}-\mathrm{NMR}\left(471 \mathrm{MHz}, \mathrm{CDCl}_{3}, 25^{\circ} \mathrm{C}, \delta\right):-114.77$ (ddd, $\left.J=13.9,8.7,5.2 \mathrm{~Hz}\right)$.

HRMS-El (m/z) calc'd for $\mathrm{C}_{13} \mathrm{H}_{8} \mathrm{O}_{4} \mathrm{~F}_{2}$ [M]', 220.06945; found, 220.06942; deviation: -0.13 ppm

4,4'-Difluorbenzophenone (S20B):

$\mathbf{R}_{\boldsymbol{f}}$ (ethyl acetate:hexanes, 30:70 (v:v) $=0.75\left(\mathrm{UV}, \mathrm{KMNO}_{4}\right)$

\section{NMR Spectroscopy:}

${ }^{1}$ H NMR $\left.\left(500 \mathrm{MHz}, \mathrm{CDCl}_{3}, 25^{\circ} \mathrm{C}, \delta\right)\right): 7.84-7.76(\mathrm{~m}, 4 \mathrm{H}), 7.22-7.10(\mathrm{~m}, 4 \mathrm{H})$.

${ }^{13} \mathrm{C}\left\{{ }^{1} \mathrm{H}\right\}$ NMR $\left(126 \mathrm{MHz}, \mathrm{CDCl}_{3}, 25^{\circ} \mathrm{C}, \delta\right): 193.9,165.5$ (d, $\left.J=254.4 \mathrm{~Hz}\right), 133.8(\mathrm{~d}, J=2.9 \mathrm{~Hz}), 132.6(\mathrm{~d}, J=$ 
$9.2 \mathrm{~Hz}), 115.7(\mathrm{~d}, J=21.9 \mathrm{~Hz})$.

${ }^{19} \mathrm{~F}-\mathrm{NMR}\left(471 \mathrm{MHz}, \mathrm{CDCl}_{3}, 25^{\circ} \mathrm{C}, \delta\right):-105.8(\mathrm{~s})$.

HRMS-EI (m/z) calc'd for $\mathrm{C}_{13} \mathrm{H}_{8} \mathrm{O}_{4} \mathrm{~F}_{2}[\mathrm{M}]^{+}, 218.0535$; found, 218.0538; deviation: +1.11 ppm

4-tert-Butylbenzaldehyde (S22)

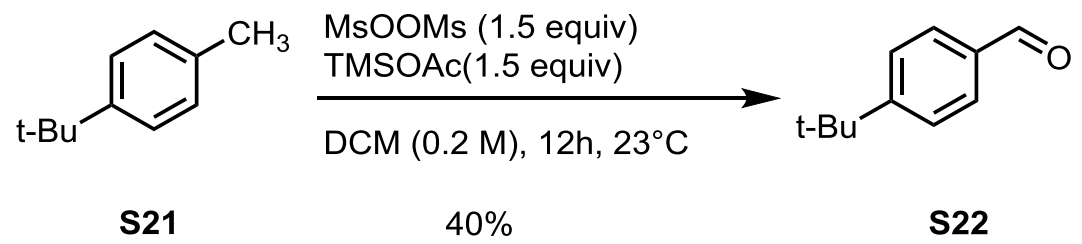

In an $\mathrm{N}_{2}$-filled glovebox, to a $4 \mathrm{~mL}$ vial containing a Teflon-coated magnetic stirring bar, 4-tert-butyltoluene (S21) $(33.7 \mu \mathrm{L}, 28.7 \mathrm{mg}, 0.200 \mathrm{mmol}, 1.00$ equiv) were added DCM (1 mL, c = 0.2 M), TMSOAc (45 $\mu \mathrm{L}, 40$ $\mathrm{mg}, 0.30 \mathrm{mmol}, 1.5$ equiv), and solid bis(methanesulfonyl) peroxide (57.0 mg, $0.300 \mathrm{mmol}, 1.50$ equiv) at $23^{\circ} \mathrm{C}$. The vial was closed with a Teflon-lined screw cap and removed from the glovebox. The reaction mixture was stirred at $23{ }^{\circ} \mathrm{C}$ for $12 \mathrm{~h}$. Aqueous sodium sulfite solution (10\% (w:w), $\left.1 \mathrm{~mL}\right)$ was added to the reaction mixture. The resulting mixture was transferred to a separation funnel and extracted with EtOAc $(3 \times$ $20 \mathrm{~mL}$ ). The combined organic layers were washed with brine $(10 \mathrm{~mL})$, dried over $\mathrm{Na}_{2} \mathrm{SO}_{4}$, and concentrated under reduced pressure. The reaction mixture was concentrated under reduced pressure The obtained residue was purified by column chromatography on silica gel eluting with a solvent mixture of ethyl acetate:hexanes (10:90 (v:v)) to afford $13 \mathrm{mg}$ of $\mathbf{S 2 2}$ as a colorless liquid (40\% yield).

$\mathbf{R}_{\boldsymbol{f}}$ (ethyl acetate:hexanes, 20:80 (v:v)) $=0.63\left(\mathrm{UV}, \mathrm{KMnO}_{4}\right)$.

\section{NMR Spectroscopy:}

${ }^{1} \mathrm{H}$ NMR $\left(500 \mathrm{MHz}, \mathrm{CDCl}_{3}, 25^{\circ} \mathrm{C}, \delta\right) .9 .98(\mathrm{~s}, 1 \mathrm{H}), 7.83-7.80(\mathrm{~m}, 2 \mathrm{H}), 7.57-7.50(\mathrm{~m}, 2 \mathrm{H}), 1.35(\mathrm{~s}, 9 \mathrm{H})$.

${ }^{13} \mathrm{C}\left\{{ }^{1} \mathrm{H}\right\}$ NMR $\left(126 \mathrm{MHz}, \mathrm{CDCl}_{3}, 25^{\circ} \mathrm{C}, \delta\right): 192.2,158.6,134.2,129.8,126.1,35.5,31.2$.

HRMS-El (m/z) calc'd for $\mathrm{C}_{11} \mathrm{H}_{14} \mathrm{O}_{4}$ [M]', 162.1041; found, 160.1039; deviation: -1.08 ppm.

Aromatic oxidation of isopentylbenzene (S4):<smiles>CC(C)CCc1ccccc1</smiles>

S4

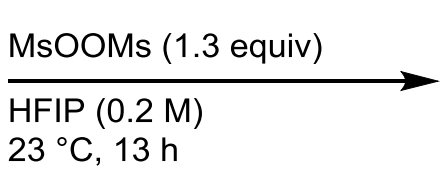

$53 \%\left({ }^{1} \mathrm{H}-\mathrm{NMR}\right)$

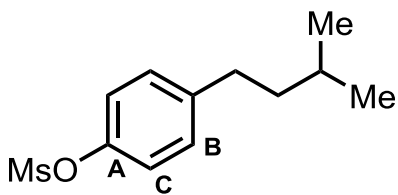

$A: B: C=13: 4: 1$

S23

Under an atmosphere of argon, a flame-dried $4 \mathrm{~mL}$ vial was charged with a teflon-coated stirring bar and isopentylbenzene (S4) $(29.7 \mathrm{mg}, 34.7 \mu \mathrm{L}, 0.200 \mathrm{mmol}, 1.00$ equiv). HFIP (1.0 mL, C = $0.20 \mathrm{M})$. was added to give a solution $(\mathrm{c}=0.20 \mathrm{M}$ ). Solid bis(methanesulfonyl) peroxide $(49.5 \mathrm{mg}, 0.260 \mathrm{mmol}, 1.30$ equiv) was 
added over roughly 30 seconds. The reaction mixture was stirred at $23^{\circ} \mathrm{C}$ for $24 \mathrm{~h}$. Aqueous sodium sulfite solution $(10 \%(w / w), 1 \mathrm{~mL})$, was added to the reaction mixture. EtOAc $(10 \mathrm{~mL})$ was added and the resulting mixture was transferred to a separation funnel. The layers were separated and the aqueous layer was extracted with EtOAc $(2 \times 10 \mathrm{~mL})$. The combined organic layers were washed with brine $(10 \mathrm{~mL})$, dried over $\mathrm{Na}_{2} \mathrm{SO}_{4}$, and concentrated under reduced pressure. To the residue was added $\mathrm{CH}_{3} \mathrm{NO}_{2}(10.8 \mu \mathrm{L}, 12.2 \mathrm{mg}$, $0.20 \mathrm{mmol}$ ) as an internal standard. The ${ }^{1} \mathrm{H}-\mathrm{NMR}$ resonance of the mesylate protons were integrated relative to the ${ }^{1} \mathrm{H}$-NMR resonance of the methyl group of nitromethane $(\delta=4.30 \mathrm{ppm})$. The ${ }^{1} \mathrm{H}-\mathrm{NMR}$ Yield was found to be $53 \%$ as combined yield of constitutional isomers.

HRMS-El (m/z) calc'd for $\mathrm{C}_{12} \mathrm{H}_{1}{ }_{8} \mathrm{O}_{3} \mathrm{~S}_{1} \mathrm{Na}_{1}[\mathrm{M}+\mathrm{Na}]^{+}$, 265.0866; found, 265.08687; deviation: +0.85 ppm.

${ }^{1} \mathrm{H}$ NMR of reaction mixture:

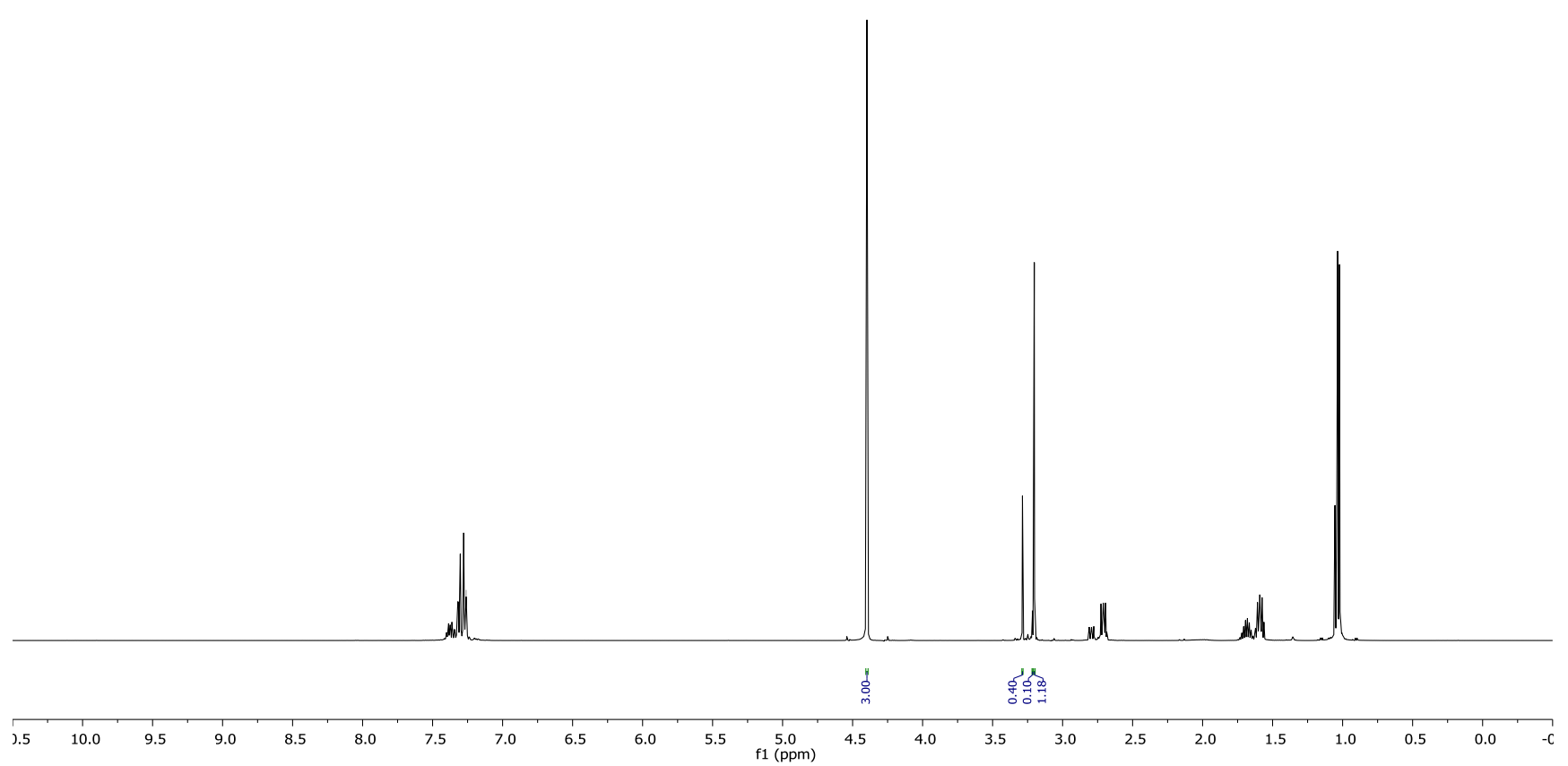

\section{Comparison of spectra of final products and benzylic mesylates or acetates.}

The ${ }^{1} \mathrm{H}$-NMR spectra of benzylic mesylate and acetate products have been acquired after aqueous work-up as described in the procedures above. 
${ }^{1} \mathrm{H}-\mathrm{NMR}$ comparison for 4-(1-hydroxybutyl) benzonitrile (7)
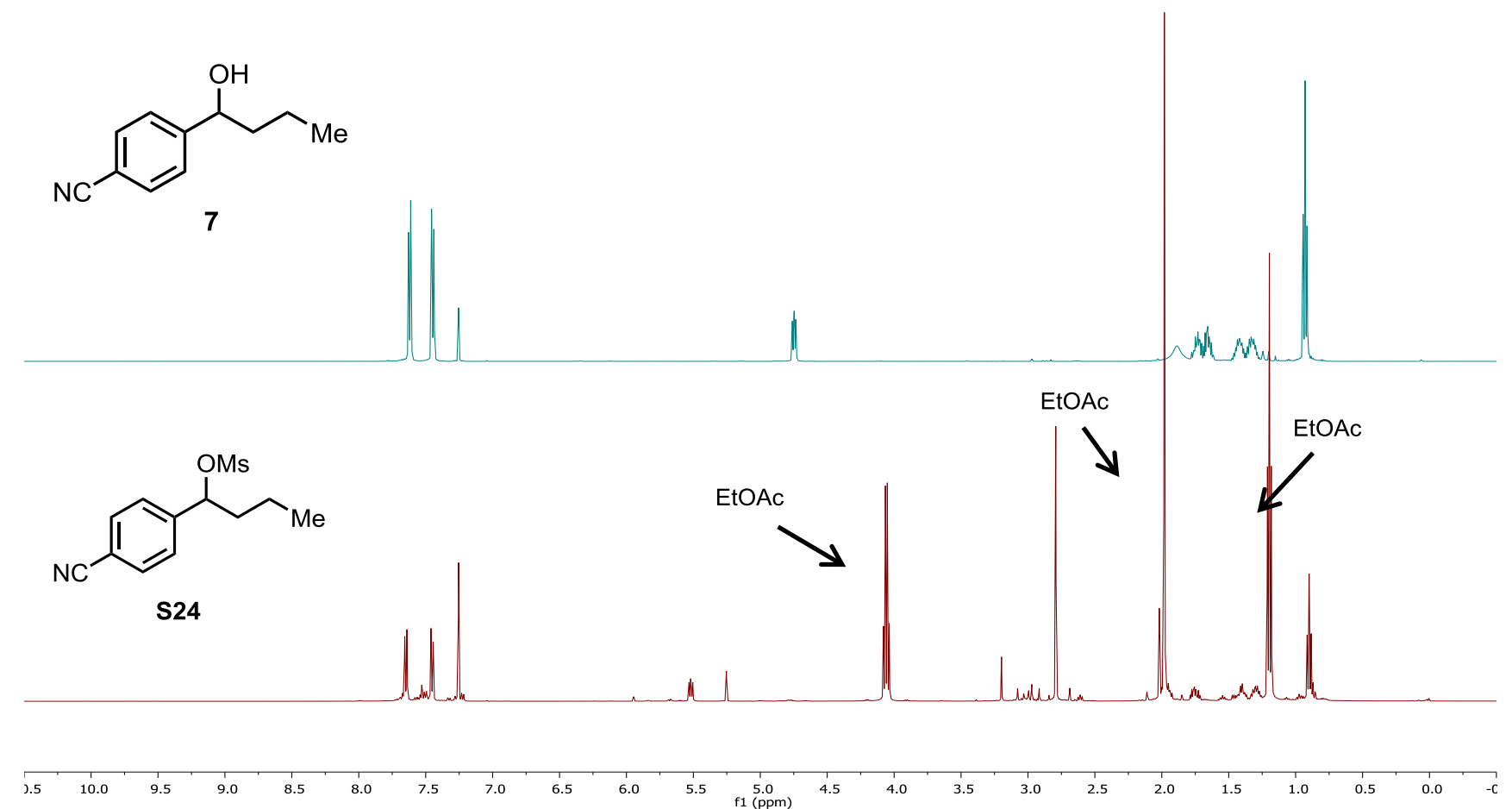

${ }^{1} \mathrm{H}-\mathrm{NMR}$ comparison for 1-phenylpent-4-yn-1-ol (9)
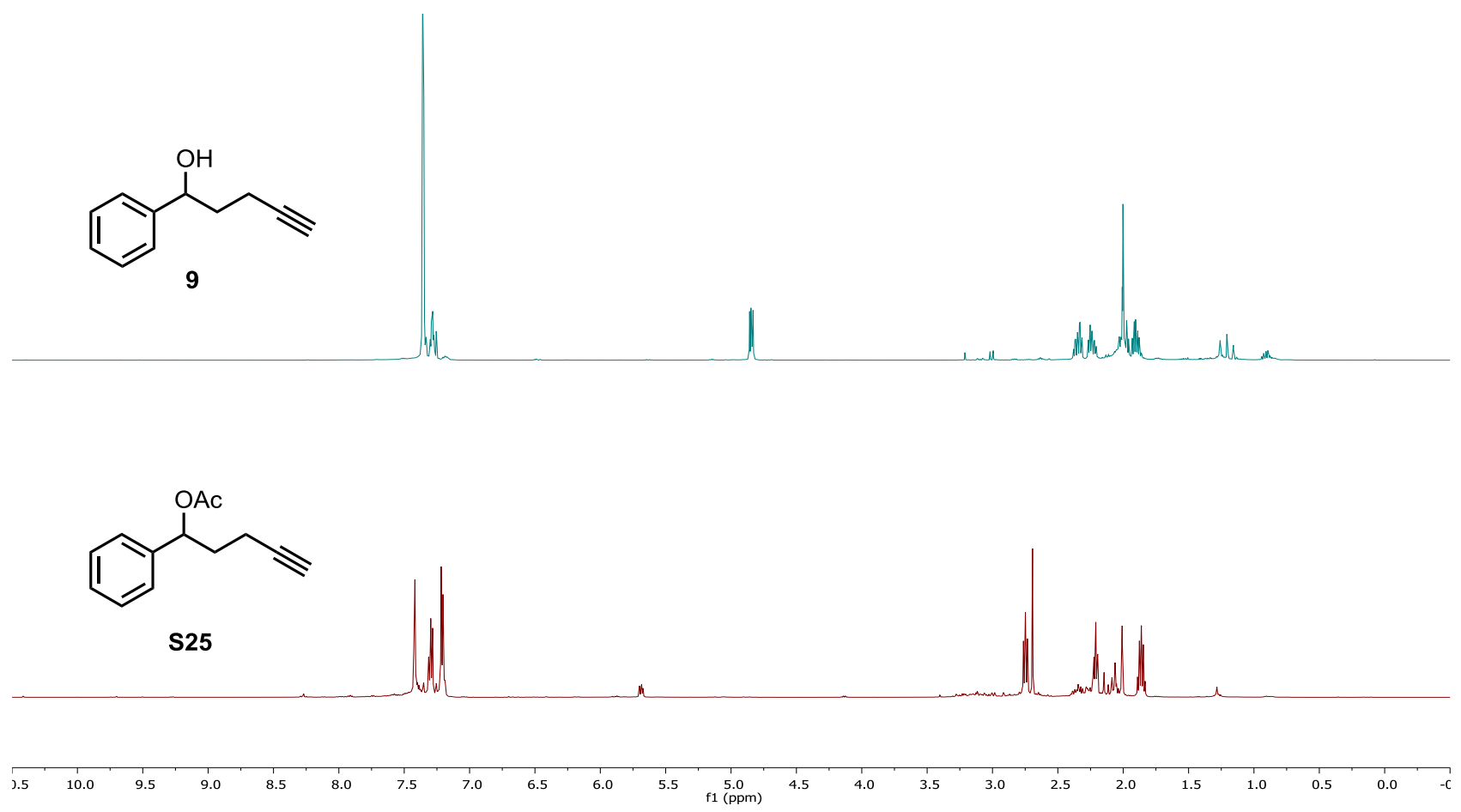
${ }^{1} \mathrm{H}-\mathrm{NMR}$ comparison for (4-isocyanophenyl) methanol (10)
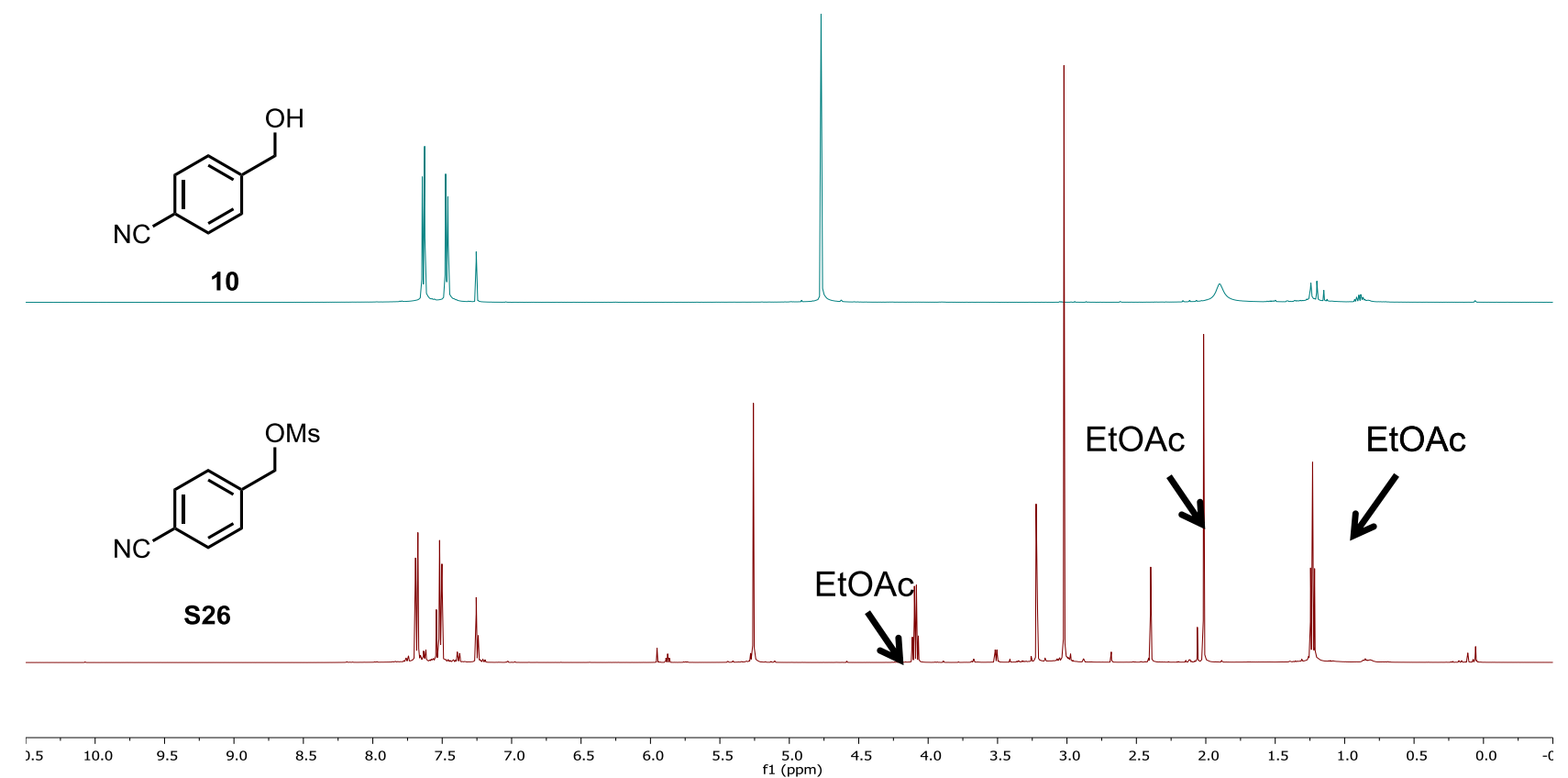

${ }^{1} \mathrm{H}-\mathrm{NMR}$ comparison for methyl-3-hydroxy-3-(3-trifluoromethyl)phenyl) propanoate.(13)<smiles>CC(=O)OCCC(O)c1cccc(C(F)(F)F)c1</smiles>

13

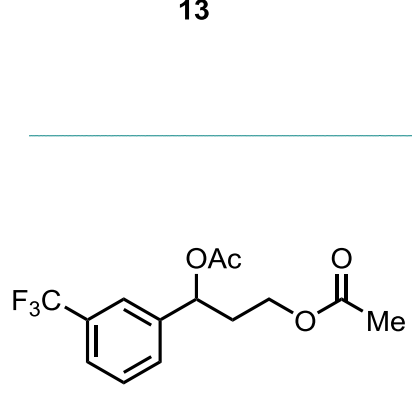

S27

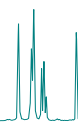

$M$
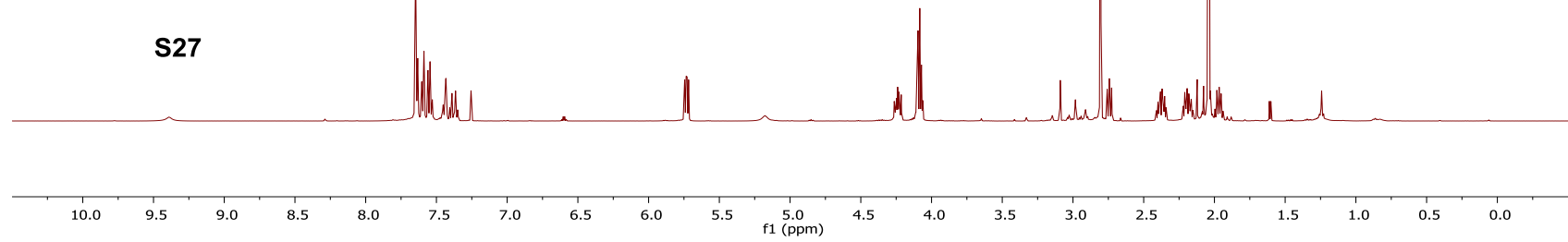
${ }^{1} \mathrm{H}-\mathrm{NMR}$ comparison for hydroxylated phenylalanine derivative 14
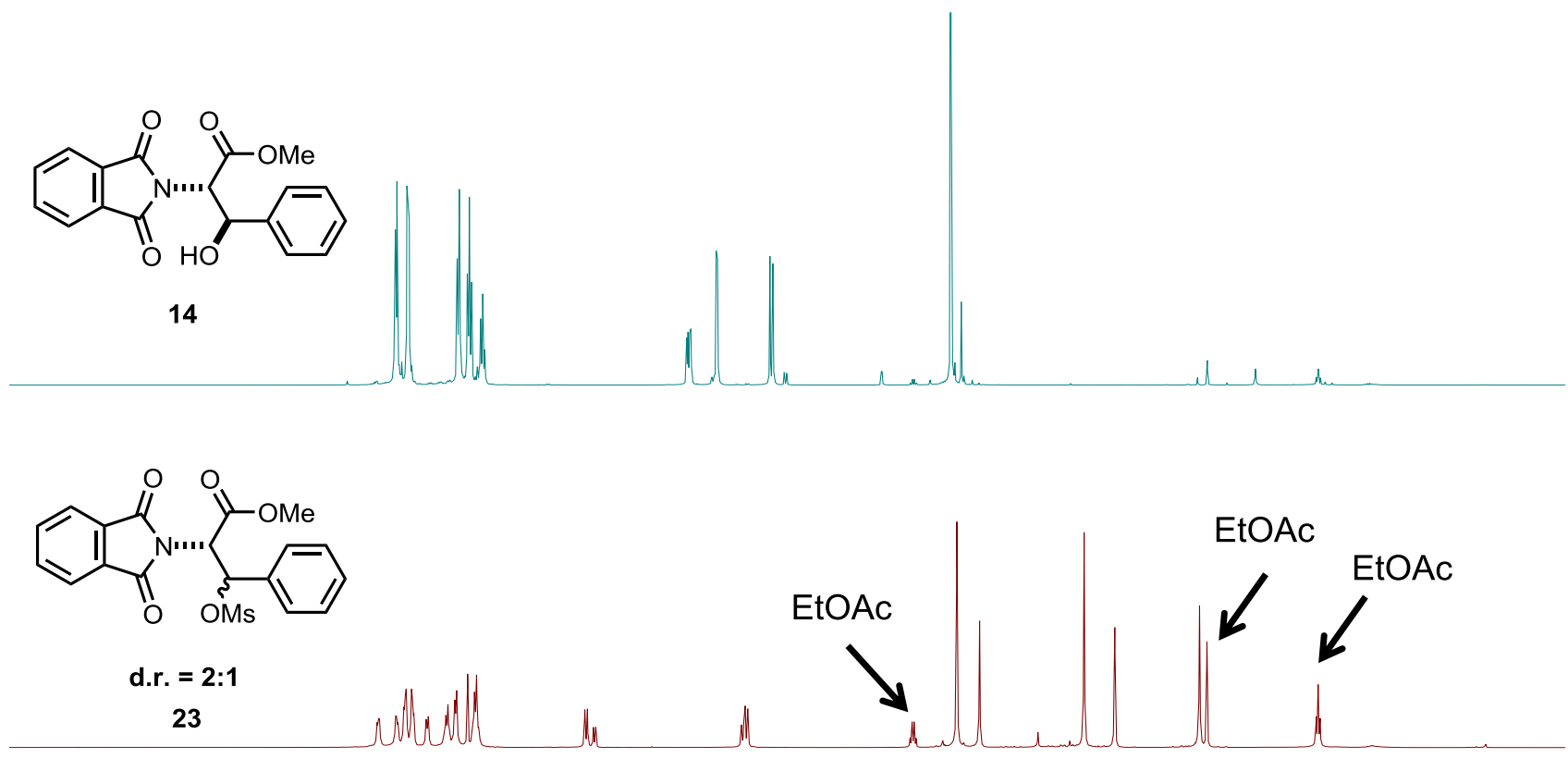

23

$0.5 \quad 100-9.5$

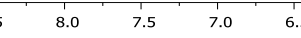

6.0

\section{Mechanistic Investigation of the benzylic $\mathrm{C}-\mathrm{H}$ oxidation reaction}

Consumption studies of TMSOAC and bis(methanesulfonyl) peroxide in dichloromethane

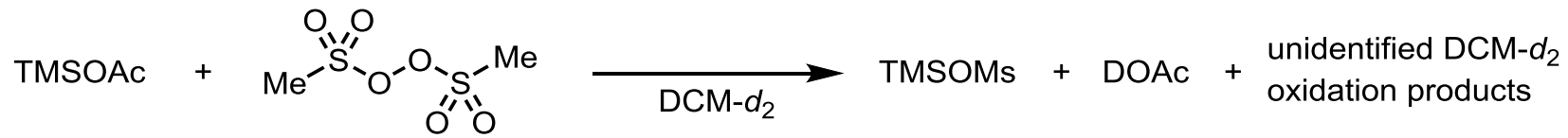

In an $\mathrm{N}_{2}$-filled glovebox, a $4 \mathrm{~mL}$-scintillation vial was charged with MsOOMs $(38.0 \mathrm{mg}, 0.200 \mathrm{mmol}$, 1.00 equiv). The peroxide was dissolved in DCM- $d_{2}$, and TMSOAC $(30.0 \mu \mathrm{L}, 26.5 \mathrm{mg}, 0.200 \mathrm{mmol}$, 1.00 equiv) were added. The resulting solution was transferred to an NMR-tube and monitored by measuring ${ }^{1} \mathrm{H}$-NMR spectra over a period of $7.5 \mathrm{~h}$. A colorless precipitate was observed after the reaction, which could not be identified and characterized. The ${ }^{1} \mathrm{H}-\mathrm{NMR}$ resonances of the TMS groups of TMSOAc $(\delta=0.26 \mathrm{ppm})$ and of TMSOMs $(\delta=0.40 \mathrm{ppm})$ were integrated relative to each other to determine the concentration of both compounds at each point in time. The ${ }^{1} \mathrm{H}$-NMR resonances of the OMs groups of MsOOMs $(\delta=3.36 \mathrm{ppm})$, an unidentified product $(\delta=3.25 \mathrm{ppm})$, and TMSOMs $(\delta=2.98 \mathrm{ppm})$ were integrated relative to each other to determine the concentration of the three compounds at each point in time. The natural logarithms of the concentration of TMSOAc and of MsOOMs were plotted versus the time. Rate constants for the consumptions of each reagent have been determined from linear fits of the data points.

${ }^{1} \mathrm{H}-\mathrm{NMR}$ after $0.5 \mathrm{~h}$ : 


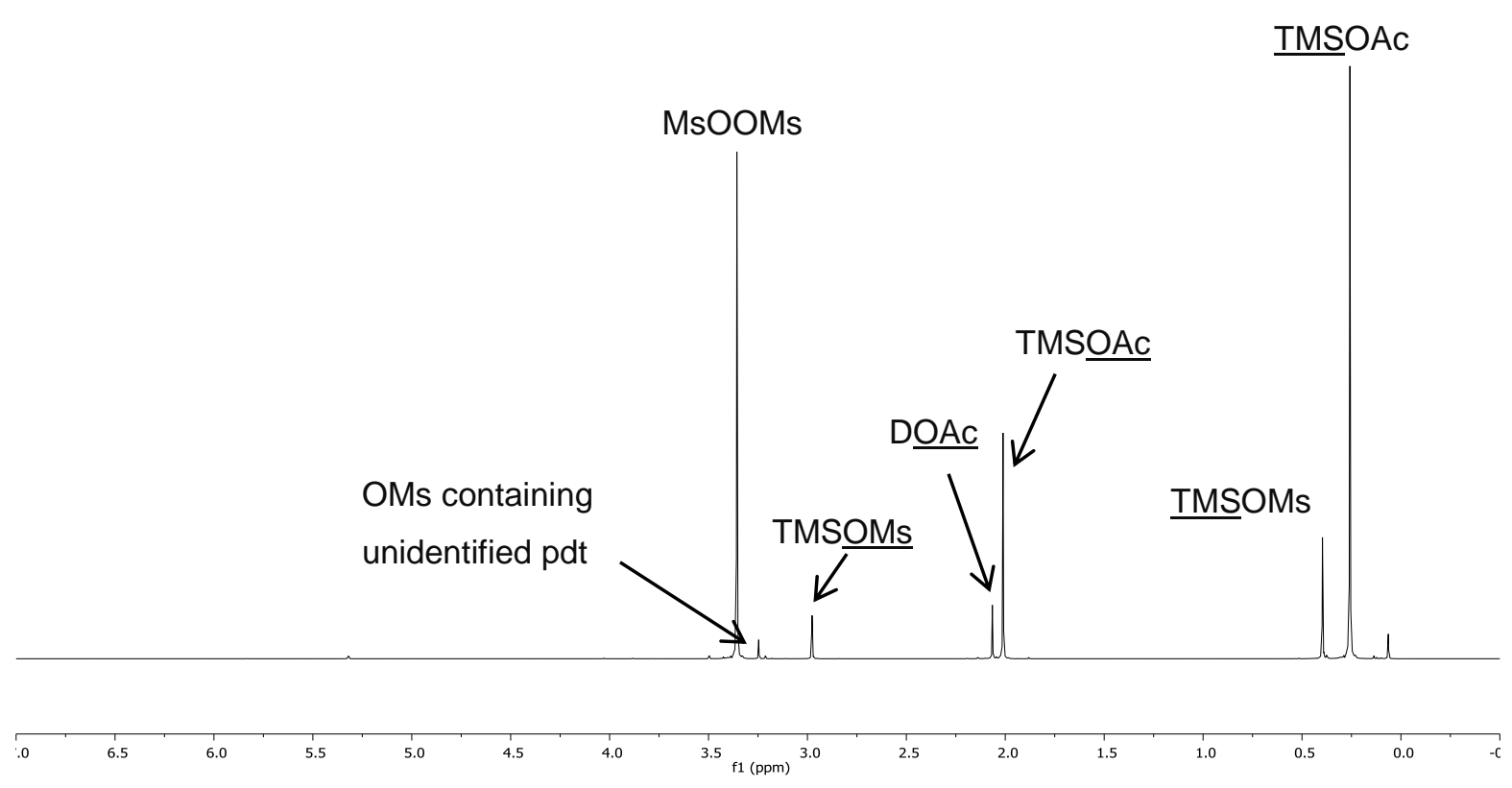

Figure S1: ${ }^{1} \mathrm{H}-\mathrm{NMR}$ after $0.5 \mathrm{~h}$.

${ }^{1} \mathrm{H}-\mathrm{NMR}$ after $7.5 \mathrm{~h}$ :

\section{TMSOMs}

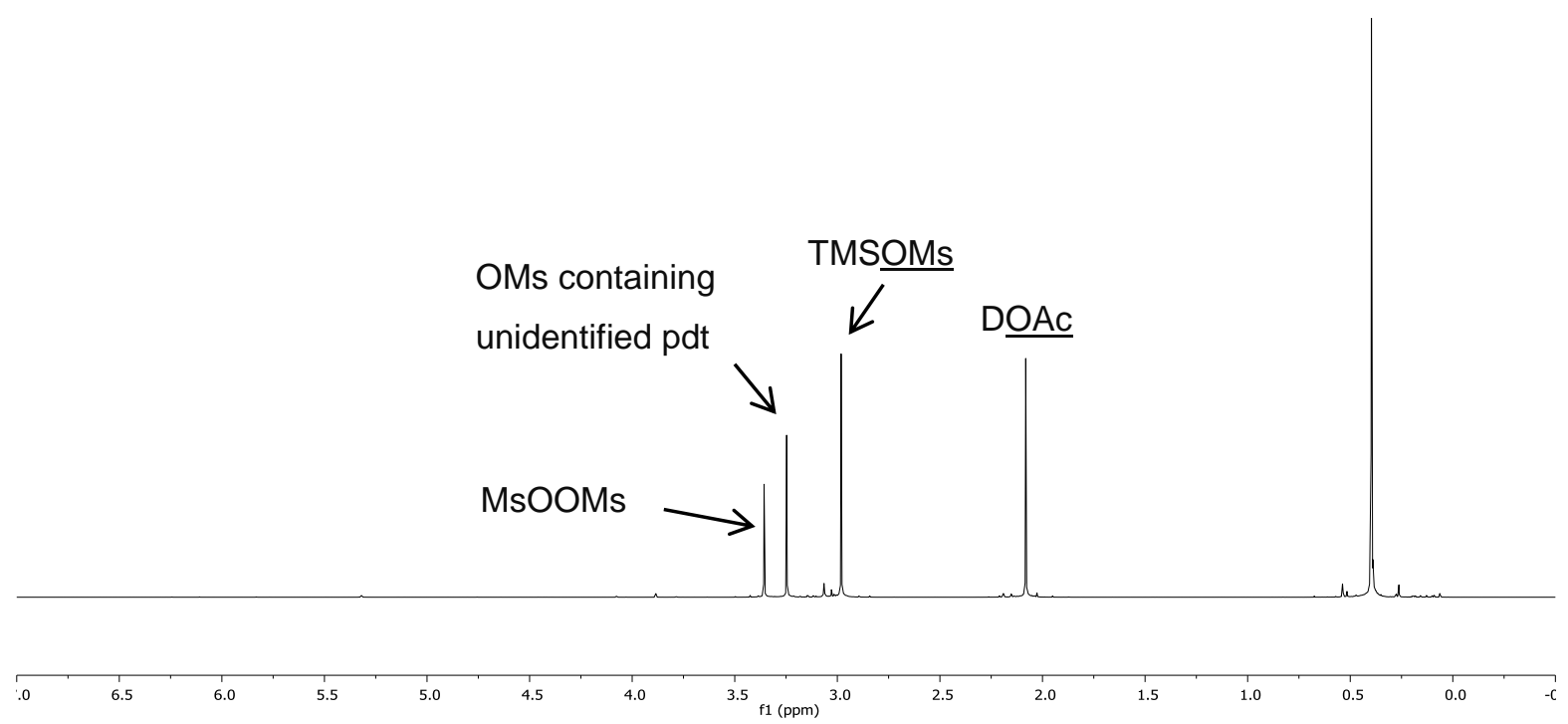

Figure S2: ${ }^{1} \mathrm{H}-\mathrm{NMR}$ after $7.5 \mathrm{~h}$. 


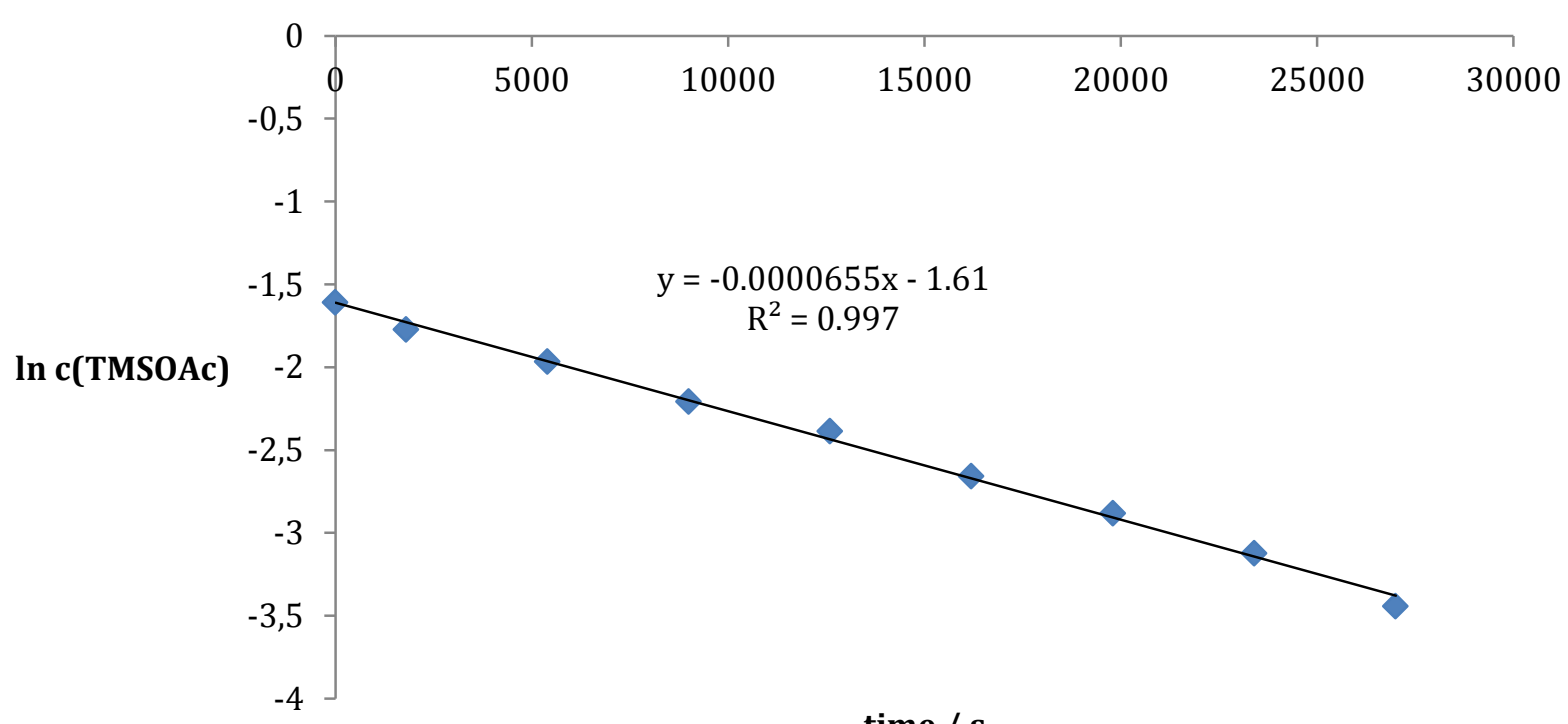

time / $s$

Figure S3: Consumption of TMSOAc.

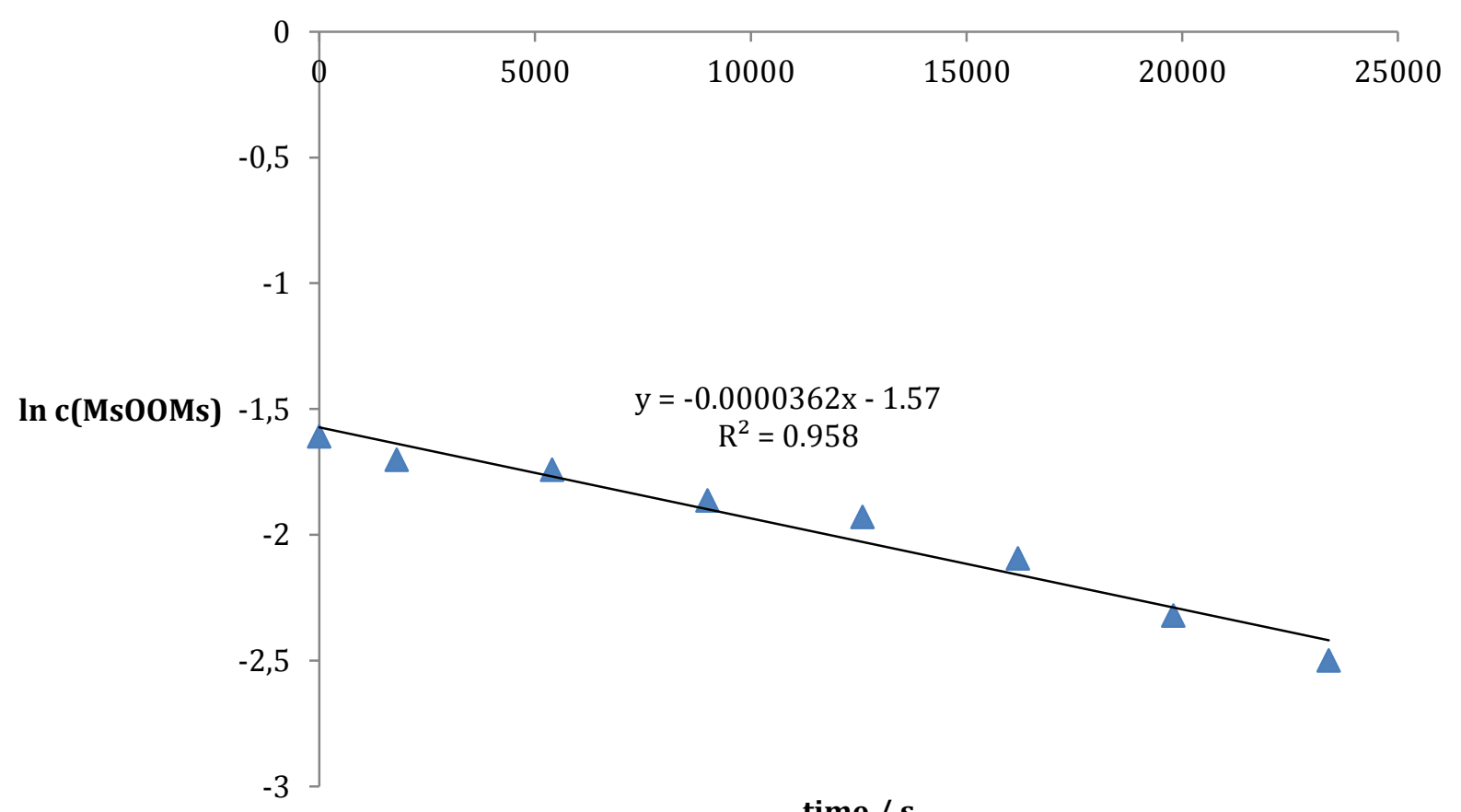

time / s

Figure S4: Consumption of MsOOMs.

First order rate constants:

Consumption of TMSOAc: $\mathrm{k}=6.6 \cdot 10^{-5} \mathrm{~s}^{-1}$

Consumption of MsOOMs: $\mathrm{k}^{\prime}=3.6 \cdot 10^{-5} \mathrm{~s}^{-1}$

The different values for the first order rate constants suggest that TMSOAC and MsOOMs are not directly reacting with each other but are consumed in independent processes. 
Consumption studies of bis(methanesulfonyl) peroxide in dichloromethane

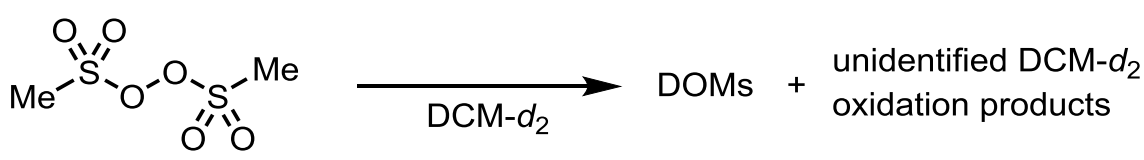

In an $\mathrm{N}_{2}$-filled glovebox, a $4 \mathrm{~mL}$-scintillation vial was charged with MsOOMs $(38.0 \mathrm{mg}, 0.200 \mathrm{mmol}$, 1.00 equiv). The peroxide was dissolved in $\mathrm{DCM}-d_{2}(1 \mathrm{~mL})$. The resulting solution was transferred to an NMR-tube and monitored by measuring ${ }^{1} \mathrm{H}$-NMR spectra over a period of $7.5 \mathrm{~h}$. A colorless precipitate was observed after the reaction, which could not be identified and characterized. The ${ }^{1} \mathrm{H}-\mathrm{NMR}$ resonances of the OMs groups of MsOOMs $(\delta=3.36 \mathrm{ppm})$, an unidentified product $(\delta=3.25 \mathrm{ppm})$, and DOMs $(\delta=3.16 \mathrm{ppm})$ were integrated relative to each other to determine the concentration of the three compounds at each point in time. The natural logarithm of the concentration of MsOOMs was plotted versus the time. The rate constant for the consumption of the reagent has been determined from a linear fit of the data points.

${ }^{1} \mathrm{H}-\mathrm{NMR}$ after $0.5 \mathrm{~h}$ :

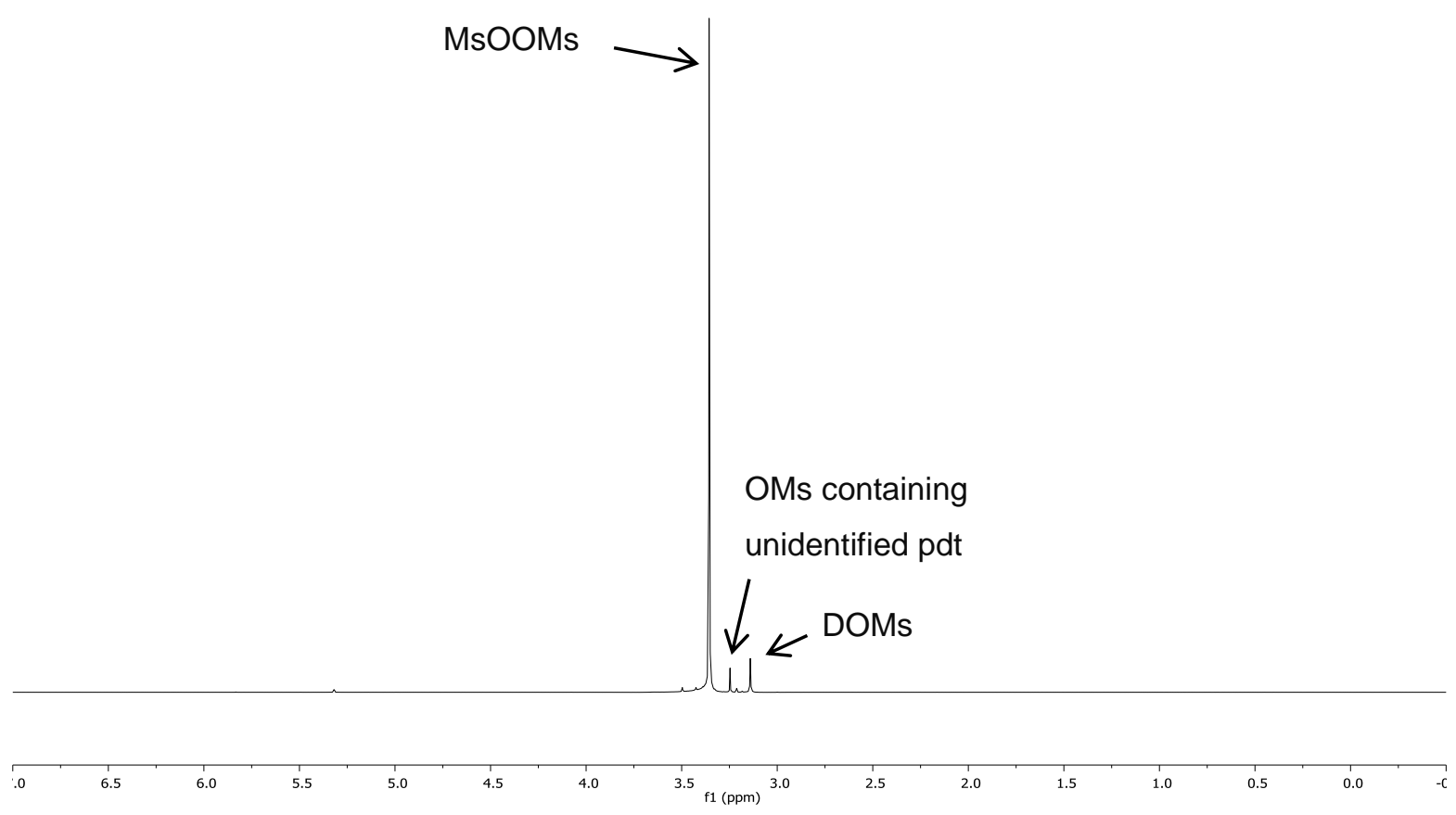

Figure S5: ${ }^{1} \mathrm{H}-\mathrm{NMR}$ after $0.5 \mathrm{~h}$.

${ }^{1} \mathrm{H}-\mathrm{NMR}$ after $7.5 \mathrm{~h}$ : 


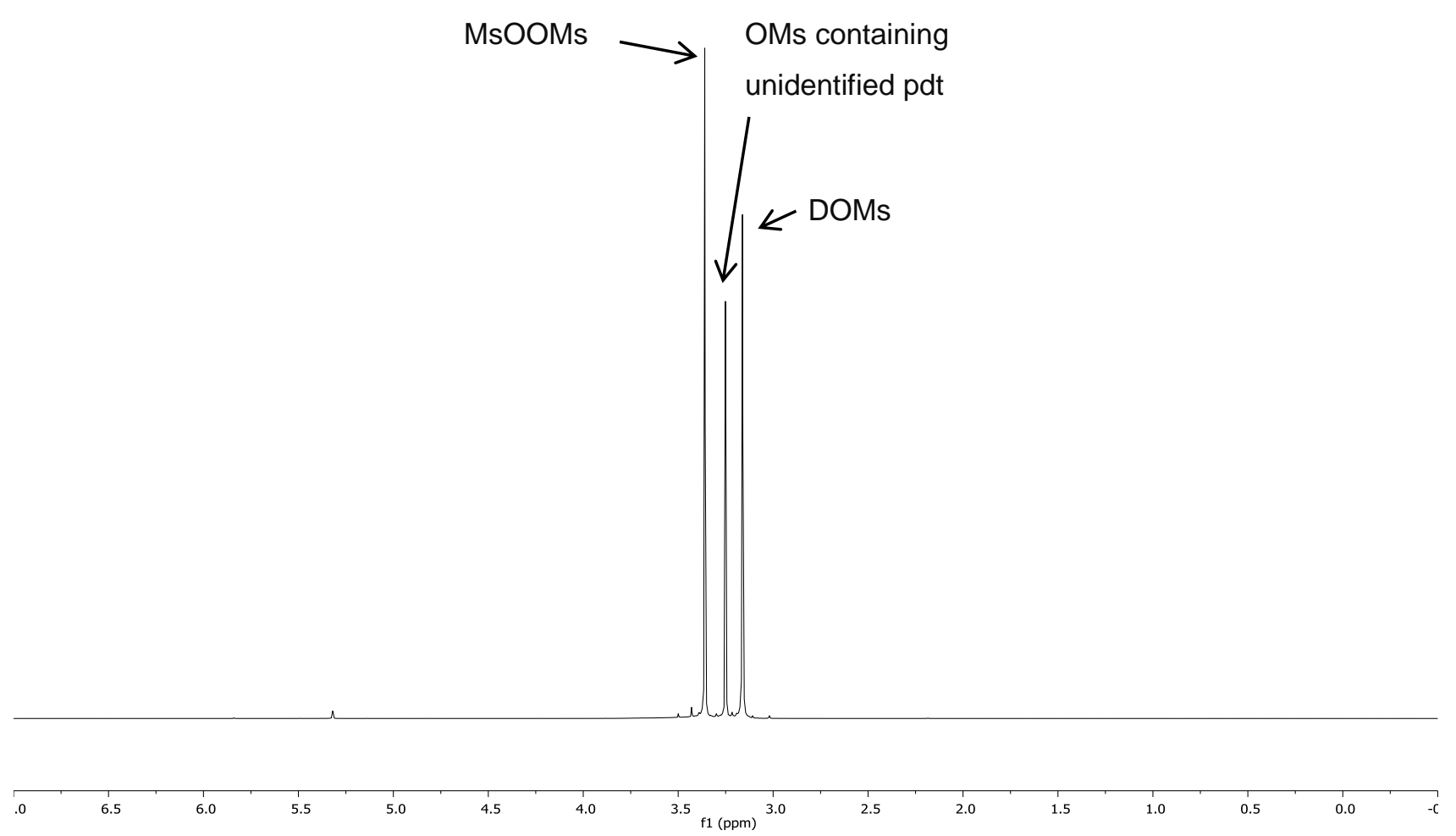

Figure S6: ${ }^{1} \mathrm{H}-\mathrm{NMR}$ after $7.5 \mathrm{~h}$.

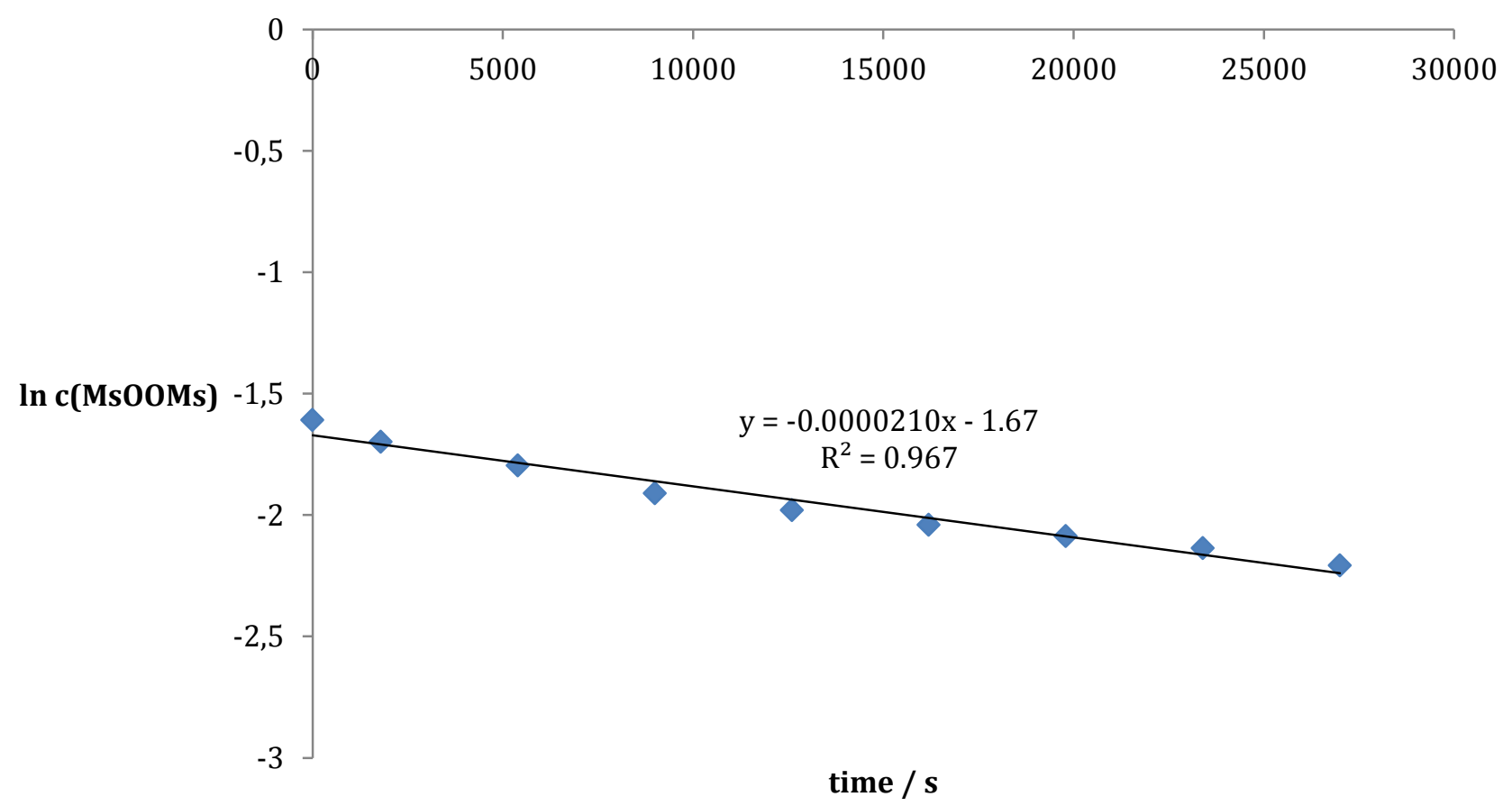

Figure S7: Consumption of MsOOMs.

First order rate constant:

Consumption of MsOOMs: $\mathrm{k}^{\prime}=2.1 \cdot 10^{-5} \mathrm{~s}^{-1}$ 
MsOOMs reacts with dichloromethane slower in the absence of TMSOAc than in the presence of TMSOAc.

Replacement of TMSOAc by 2,6-di-tert-butyl pyridine

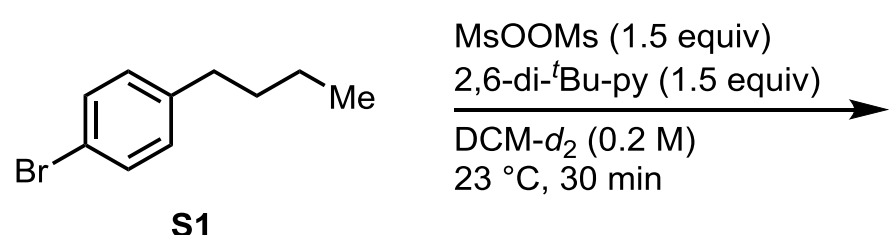

S1

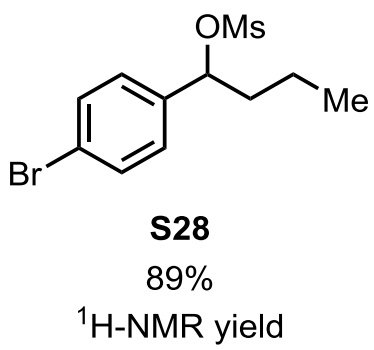

In an $\mathrm{N}_{2}$-filled glovebox, a $4 \mathrm{~mL}$-scintillation vial was charged with DCM- $d_{2}(1 \mathrm{~mL})$. The substrate $\mathbf{S} 1(35.5 \mu \mathrm{L}$, $42.6 \mathrm{mg}, 0.200 \mathrm{mmol}, 1.00$ equiv) was added. Nitromethane (10.8 $\mu \mathrm{L}, 12.2 \mathrm{mg}, 0.200 \mathrm{mmol}, 1.00$ equiv) as internal standard was added followed by addition of MsOOMs $(57.1 \mathrm{mg}, 0.300 \mathrm{mmol}, 1.50$ equiv) and 2,6-ditert-butyl pyridine $(67.4 \mu \mathrm{L}, 57.4 \mathrm{mg}, 0.300 \mathrm{mmol}, 1.50$ equiv). The resulting solution was transferred to an NMR-tube and a ${ }^{1} \mathrm{H}$-NMR spectra was measured after $30 \mathrm{~min}$. The ${ }^{1} \mathrm{H}$-NMR resonance of the benzylic proton of the product $\mathbf{S} 28$ ( $\delta=5.45 \mathrm{ppm}$ ) was integrated relative to the ${ }^{1} \mathrm{H}$-NMR resonance of the methyl group of nitromethane $(\delta=4.30 \mathrm{ppm})$. The ${ }^{1} \mathrm{H}-\mathrm{NMR}$ yield of the desired product was found to be $89 \%$.

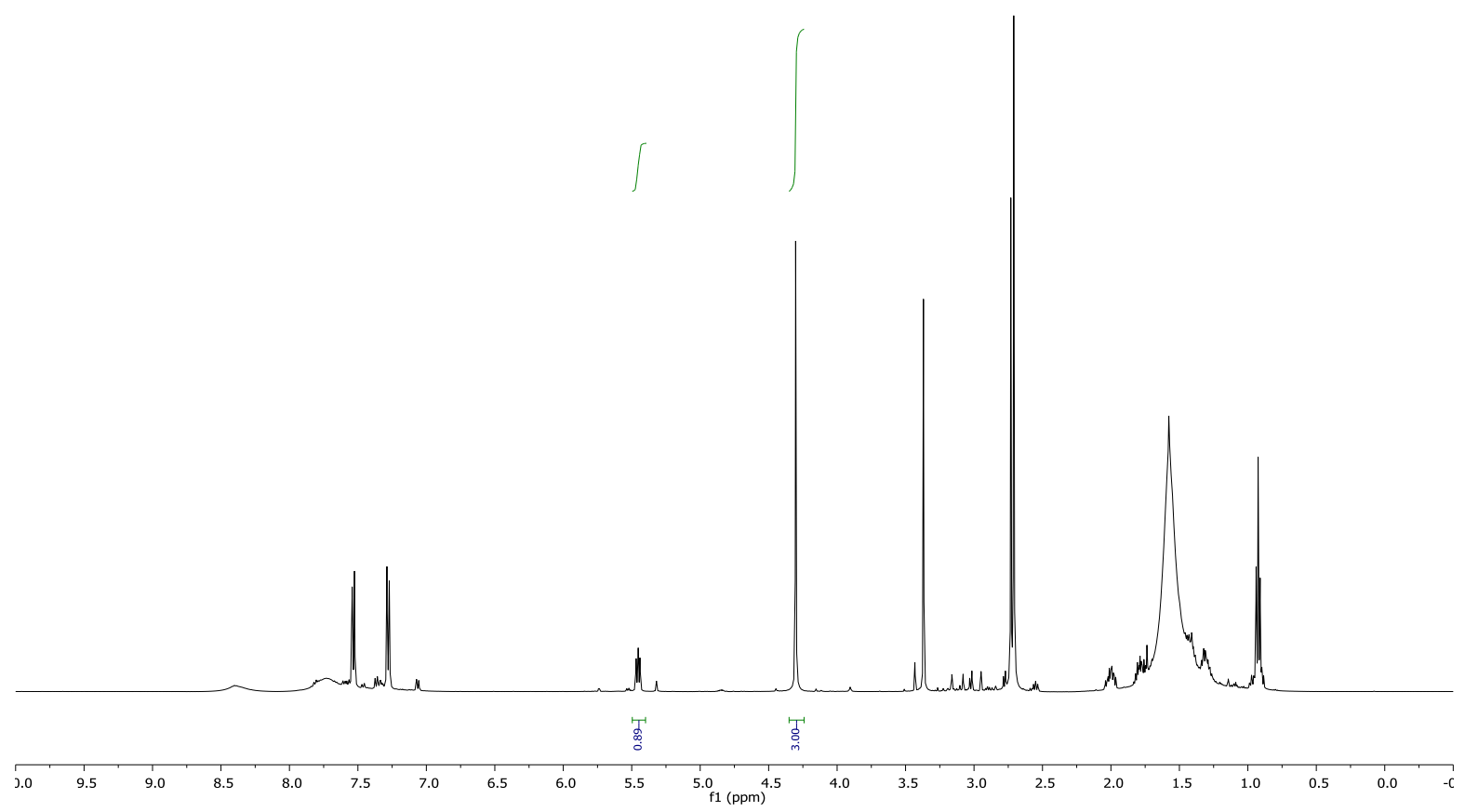

Figure S8: ${ }^{1} \mathrm{H}-\mathrm{NMR}$ after $30 \mathrm{~min}$. 
Reaction with no base added<smiles>CCCCc1ccc(Br)cc1</smiles>

s1

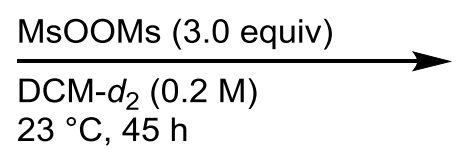

$23^{\circ} \mathrm{C}, 45 \mathrm{~h}$<smiles>CC[C@H](OC)[C@H](OC)c1ccc(Br)cc1</smiles>

1:1 mixture $32 \%$

$\mathbf{S 2 9}$

In an $\mathrm{N}_{2}$-filled glovebox, a $4 \mathrm{~mL}$-scintillation vial was charged with DCM- $d_{2}(1 \mathrm{~mL})$. The substrate $\mathbf{S 1}(35.5 \mu \mathrm{L}$, $42.6 \mathrm{mg}, 0.200 \mathrm{mmol}, 1.00$ equiv) was added. Nitromethane ( $10.8 \mu \mathrm{L}, 12.2 \mathrm{mg}, 0.200 \mathrm{mmol}, 1.00$ equiv) as internal standard was added followed by addition of MsOOMs (57.1 mg, $0.300 \mathrm{mmol}, 1.50$ equiv). The resulting solution was transferred to an NMR-tube and monitored by ${ }^{1} \mathrm{H}-\mathrm{NMR}$ spectroscopy over a period of $30 \mathrm{~h}$. The ${ }^{1} \mathrm{H}$-NMR resonance of the aromatic protons of the starting material $\mathbf{S} 1(\delta=7.07 \mathrm{ppm})$ was integrated relative to the ${ }^{1} \mathrm{H}$-NMR resonance of the methyl group of nitromethane $(\delta=4.30 \mathrm{ppm})$ to indicate that $46 \%$ of starting material remained. Peroxide $1(57.1 \mathrm{mg}, 0.300 \mathrm{mmol}, 1.50$ equiv) was added and the reaction was monitored over a period of $15 \mathrm{~h}$. The starting material was completely consumed The ${ }^{1} \mathrm{H}-\mathrm{NMR}$ resonances of the benzylic protons of the products $\mathbf{S} 29(\delta=5.74 \mathrm{ppm}$ and $\delta=5.54 \mathrm{ppm})$ were integrated relative to the ${ }^{1} \mathrm{H}$-NMR resonance of the methyl group of nitromethane $(\delta=4.30 \mathrm{ppm})$ to give a combined $1 \mathrm{H}$ NMR yield of $51 \%$. The reaction mixture was purified by flash chromatography on silica gel eluting with a mixture of hexanes:EtOAc $=60: 40(\mathrm{v}: \mathrm{v})$ to give $25.3 \mathrm{mg}$ of the compounds $\mathbf{S 2 9}$ as a colorless oil (32\% yield).

$\mathbf{R}_{f}$ (ethyl acetate:hexanes, 40:60 (v:v)) $=0.39\left(\mathrm{UV}, \mathrm{KMnO}_{4}\right)$.

\section{NMR Spectroscopy (1:1 mixture of diastereomers):}

${ }^{1} \mathrm{H}$ NMR $\left(500 \mathrm{MHz}, \mathrm{CD}_{2} \mathrm{Cl}_{2}, 25^{\circ} \mathrm{C}, \delta\right): 7.67-7.54(\mathrm{~m}, 4 \mathrm{H}), 7.32(\mathrm{dd}, J=8.5,3.1 \mathrm{~Hz}, 4 \mathrm{H}), 5.72(\mathrm{~d}, J=3.9 \mathrm{~Hz}$, $1 \mathrm{H}), 5.51(\mathrm{~d}, J=7.7 \mathrm{~Hz}, 1 \mathrm{H}), 4.89-4.81(\mathrm{~m}, 2 \mathrm{H}), 3.05(\mathrm{~s}, 3 \mathrm{H}), 2.99(\mathrm{~s}, 3 \mathrm{H}), 2.92(\mathrm{~s}, 3 \mathrm{H}), 2.76(\mathrm{~s}, 3 \mathrm{H}), 1.72-$ $1.44(\mathrm{~m}, 6 \mathrm{H}), 1), 1.00-0.96(\mathrm{~m}, 6 \mathrm{H})$.

${ }^{13} \mathrm{C}\left\{{ }^{1} \mathrm{H}\right\}$ NMR $\left(126 \mathrm{MHz}, \mathrm{CDCl}_{3}, 25^{\circ} \mathrm{C}, \delta\right): 134.0,133.9,133.1,132.7$ 129.9, 129.5, 124.8, 124.1, 84.7, 84.0, 83.1, 82.4, 39.9, 39.6, 39.5, 39.2, 24.8, 23.0, 10.0, 9.4.

HRMS-ESI(m/z) calc'd for $\mathrm{C}_{12} \mathrm{H}_{17} \mathrm{O}_{6} \mathrm{~S}_{2} \mathrm{BrNa}[\mathrm{M}+\mathrm{Na}]^{+}$, 422.9542; found, 422.9539; deviation: -0.8 ppm. 
Reaction Monitoring: conversion of benzylic mesylate to benzylic acetate and styrene over time.

$\mathrm{Br}$<smiles>CCCCc1ccc(Br)cc1</smiles>

s1
MsOOMs (1.5 equiv)

TMSOAc (3.0 equiv)

$\mathrm{DCM}-d_{2}(0.2 \mathrm{M})$

$23^{\circ} \mathrm{C}, 12 \mathrm{~h}$
$\mathrm{Br}$<smiles>CCCC(OC)c1ccc(I)cc1</smiles>

528<smiles>CCCC(OC(C)=O)c1ccc(Br)cc1</smiles>

S30

$+$<smiles>CC/C=C/c1ccc(Br)cc1</smiles>

S31

In an $\mathrm{N}_{2}$-filled glovebox, a $4 \mathrm{~mL}$-scintillation vial was charged with $\mathrm{DCM}-\mathrm{d}_{2}(1 \mathrm{~mL})$. The substrate $\mathrm{S} 1(35.5 \mu \mathrm{L}$, $42.6 \mathrm{mg}, 0.200 \mathrm{mmol}, 1.00$ equiv) was added. Nitromethane (10.8 $\mu \mathrm{L}, 12.2 \mathrm{mg}, 0.200 \mathrm{mmol}, 1.00$ equiv) as internal standard was added followed by addition of MsOOMs (57.1 mg, $0.300 \mathrm{mmol}, 1.50$ equiv) and TMSOAc $(90.0 \mu \mathrm{L}, 79.3 \mathrm{mg}, 0.600 \mathrm{mmol}, 3.00$ equiv). The resulting solution was transferred to an NMR-tube and monitored by ${ }^{1} \mathrm{H}-\mathrm{NMR}$ spectroscopy. The ${ }^{1} \mathrm{H}-\mathrm{NMR}$ resonances of the benzylic proton of the product $\mathbf{S 2 8}$ $(\delta=5.45 \mathrm{ppm})$, the benzylic proton of product $\mathbf{S} 3 \mathbf{0}(\delta=5.64 \mathrm{ppm})$, and the olefinic protons of product $\mathbf{S} 31$ ( $\delta$ $=6.31-6.29 \mathrm{ppm})$ were integrated relative to the ${ }^{1} \mathrm{H}-\mathrm{NMR}$ resonance of the methyl group of nitromethane $(\delta$ $=4.30 \mathrm{ppm})$.

Table S1: Results of Reaction Monitoring

\begin{tabular}{|c|c|c|c|}
\hline Time / min & Yield of S28 & Yield of S30 & Yield of S31 \\
\hline 20 & $94 \%$ & $<1 \%$ & $<1 \%$ \\
\hline 30 & $94 \%$ & $<1 \%$ & $<1 \%$ \\
\hline 40 & $94 \%$ & $2 \%$ & $<1 \%$ \\
\hline 70 & $92 \%$ & $3 \%$ & $<1 \%$ \\
\hline 90 & $91 \%$ & $6 \%$ & $2 \%$ \\
\hline 250 & $80 \%$ & $15 \%$ & $<1 \%$ \\
\hline 740 & $64 \%$ & & $<\%$ \\
\hline
\end{tabular}



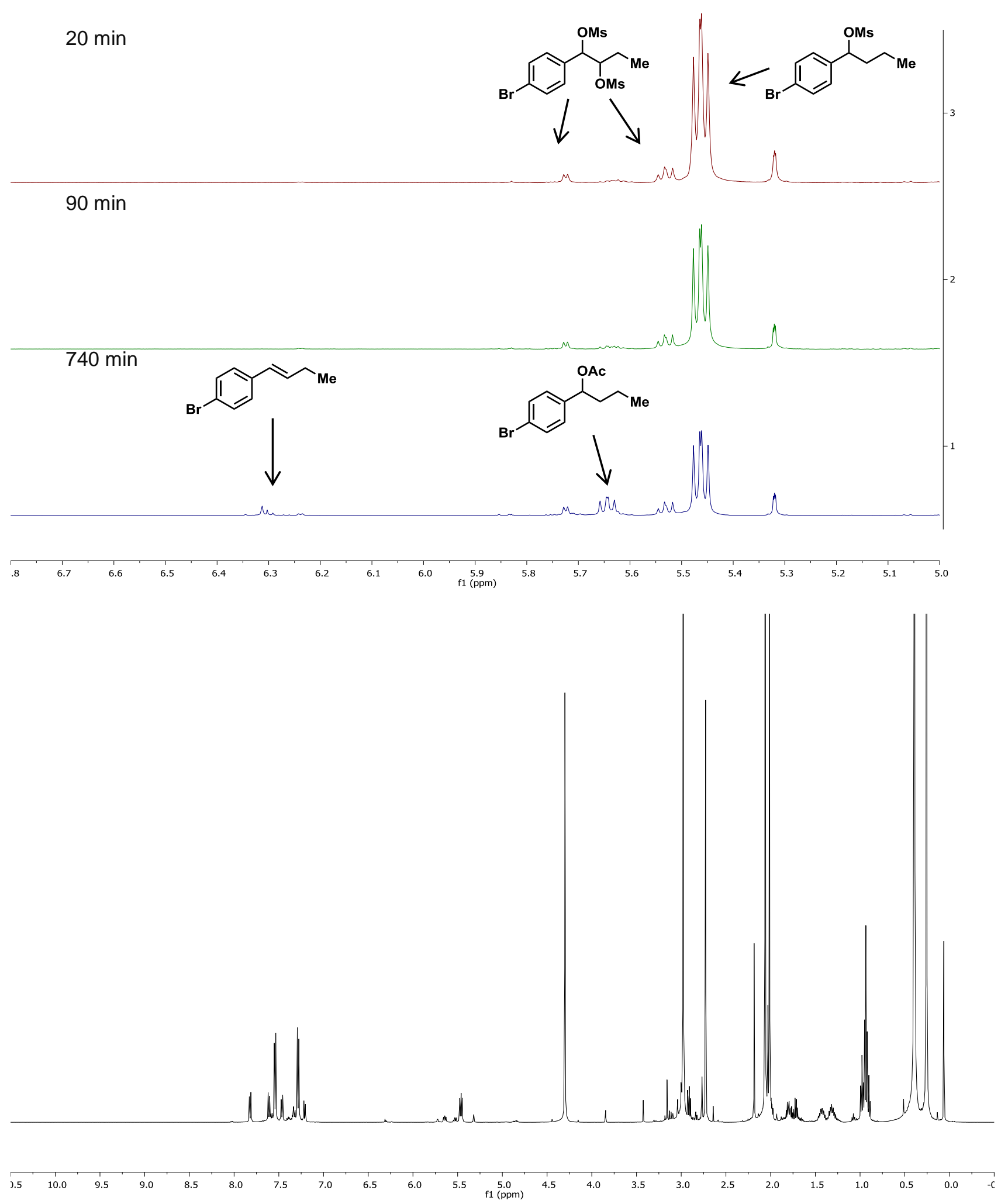

Figure S9: (top) Parts of ${ }^{1} \mathrm{H}$-NMR spectra at different time points and (botton) ${ }^{1} \mathrm{H}$-NMR spectrum after 740 min. 
Addition of ethanesulfonic acid to the standard reaction mixture

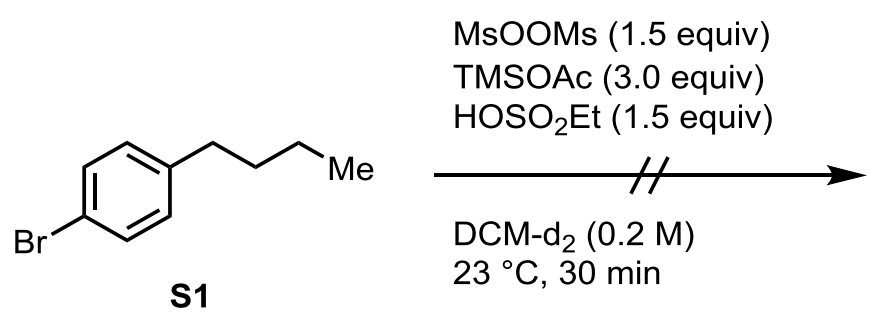<smiles>CCCC(OS(C)(=O)=O)c1ccc(Br)cc1</smiles>

In an $\mathrm{N}_{2}$-filled glovebox, a $4 \mathrm{~mL}$-scintillation vial was charged with DCM- $d_{2}(1 \mathrm{~mL})$. The substrate $\mathbf{S 1}(35.5 \mu \mathrm{L}$, $42.6 \mathrm{mg}, 0.200 \mathrm{mmol}, 1.00$ equiv) was added. Nitromethane ( $10.8 \mu \mathrm{L}, 12.2 \mathrm{mg}, 0.200 \mathrm{mmol}, 1.00$ equiv) as internal standard was added followed by addition of MsOOMs (57.1 mg, $0.300 \mathrm{mmol}, 1.50$ equiv) and TMSOAc ( $90.0 \mu \mathrm{L}, 79.3 \mathrm{mg}, 0.600 \mathrm{mmol}, 3.00$ equiv). The resulting solution was transferred to an NMR-tube and taken out of the glovebox. Ethanesulfonic acid ( $24.6 \mu \mathrm{L}, 33.0 \mathrm{mg}, 0.300 \mathrm{mmol}, 1.50$ equiv) were added and the reaction was monitored by ${ }^{1} \mathrm{H}$-NMR spectroscopy. The ${ }^{1} \mathrm{H}-\mathrm{NMR}$ resonances of the benzylic proton of the product $\mathbf{S} 28(\delta=5.45 \mathrm{ppm})$, the benzylic proton of product $\mathbf{S} 30(\delta=5.64 \mathrm{ppm})$, and the olefinic protons of product $\mathbf{S} 31(\delta=6.31-6.29 \mathrm{ppm})$ were integrated relative to the ${ }^{1} \mathrm{H}$-NMR resonance of the methyl group of nitromethane $(\delta=4.30 \mathrm{ppm})$. A benzylic ethanesulfonate product was not observed.

Table S2: Results of Reaction Monitoring

\begin{tabular}{|c|c|c|c|}
\hline Time / $\min$ & Yield of S28 & Yield of S30 & Yield of S31 \\
\hline 20 & $71 \%$ & $16 \%$ & $1 \%$ \\
\hline 45 & $47 \%$ & $39 \%$ & $4 \%$ \\
\hline 75 & $21 \%$ & $66 \%$ & $8 \%$ \\
\hline 105 & $8 \%$ & $80 \%$ & $1 \%$ \\
\hline
\end{tabular}



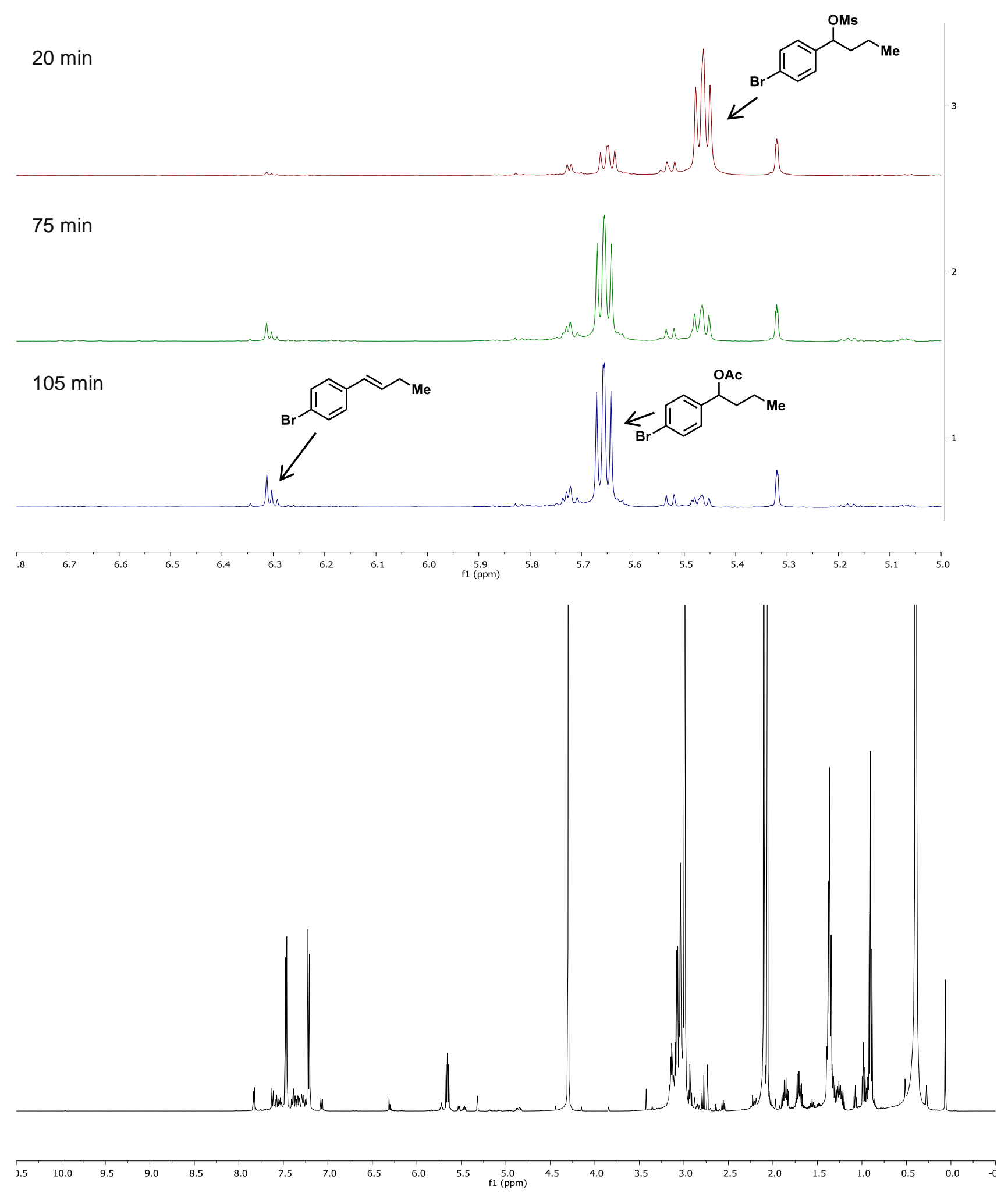

Figure S10: (top) Parts of ${ }^{1} \mathrm{H}-\mathrm{NMR}$ spectra at different time points and (bottom) ${ }^{1} \mathrm{H}$-NMR spectrum after 105 min. 
Intermolecular kinetic isotope effect (KIE) experiment

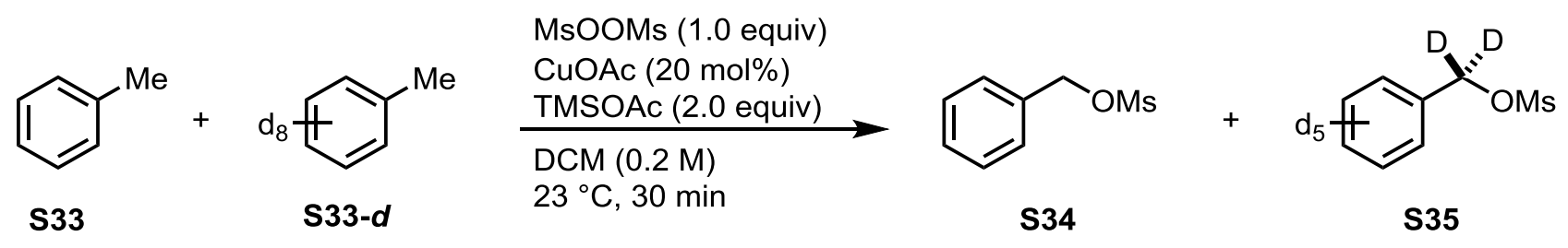

In an $\mathrm{N}_{2}$-filled glovebox, a $4 \mathrm{~mL}$-scintillation vial was charged with a Teflon-coated magnetic stirring bar, CuOAc (2.45 mg, $20.0 \mu \mathrm{mol}, 20 \mathrm{~mol} \%)$, DCM (0.5 mL), toluene (S33) (53.3 $\mu \mathrm{L}, 46.1 \mathrm{mg}, 0.500 \mathrm{mmol}, 5.00$ equiv), and toluene- $\mathrm{d}_{8}(\mathbf{S} 33-\boldsymbol{d})(53.1 \mu \mathrm{L}, 50.1 \mathrm{mg}, 0.500 \mathrm{mmol}, 5.00$ equiv). MsOOMs (19.0 mg, $0.100 \mathrm{mmol}$, 1.00 equiv) and TMSOAc (30.0 $\mu \mathrm{L}, 26.4 \mathrm{mg}, 0.200 \mathrm{mmol}, 2.00$ equiv) were added. The vial was sealed with a Teflon-lined cap, taken out of the glovebox, and stirred at $23^{\circ} \mathrm{C}$ for $30 \mathrm{~min}$. Brine $(1 \mathrm{~mL})$ was added to the stirring solution. The reaction mixture was transferred to a separation funnel, and the organic and aqueous layer were separated. The aqueous layer was washed with DCM $(2 \mathrm{~mL})$. The combined organic layers were dried over $\mathrm{MgSO}_{4}$ and concentrated in vacuo. The colorless residue was analyzed by ${ }^{1} \mathrm{H}-\mathrm{NMR}$ spectroscopy in $\mathrm{CD}_{2} \mathrm{Cl}_{2}$. The resulting ${ }^{1} \mathrm{H}$ resonances of the mesyl groups $(\delta=2.92 \mathrm{ppm})$ were integrated relative to the benzylic ${ }^{1} \mathrm{H}$ proton resonances of the non-deuterated product $(\delta=5.23 \mathrm{ppm}) \mathbf{S 3 4}$ to calculate the intermolecular kinetic isotope effect (equation 1).

$$
\frac{\mathrm{k}_{\mathrm{H}}}{\mathrm{k}_{\mathrm{D}}}=\frac{3.0}{1.7}=1.8
$$

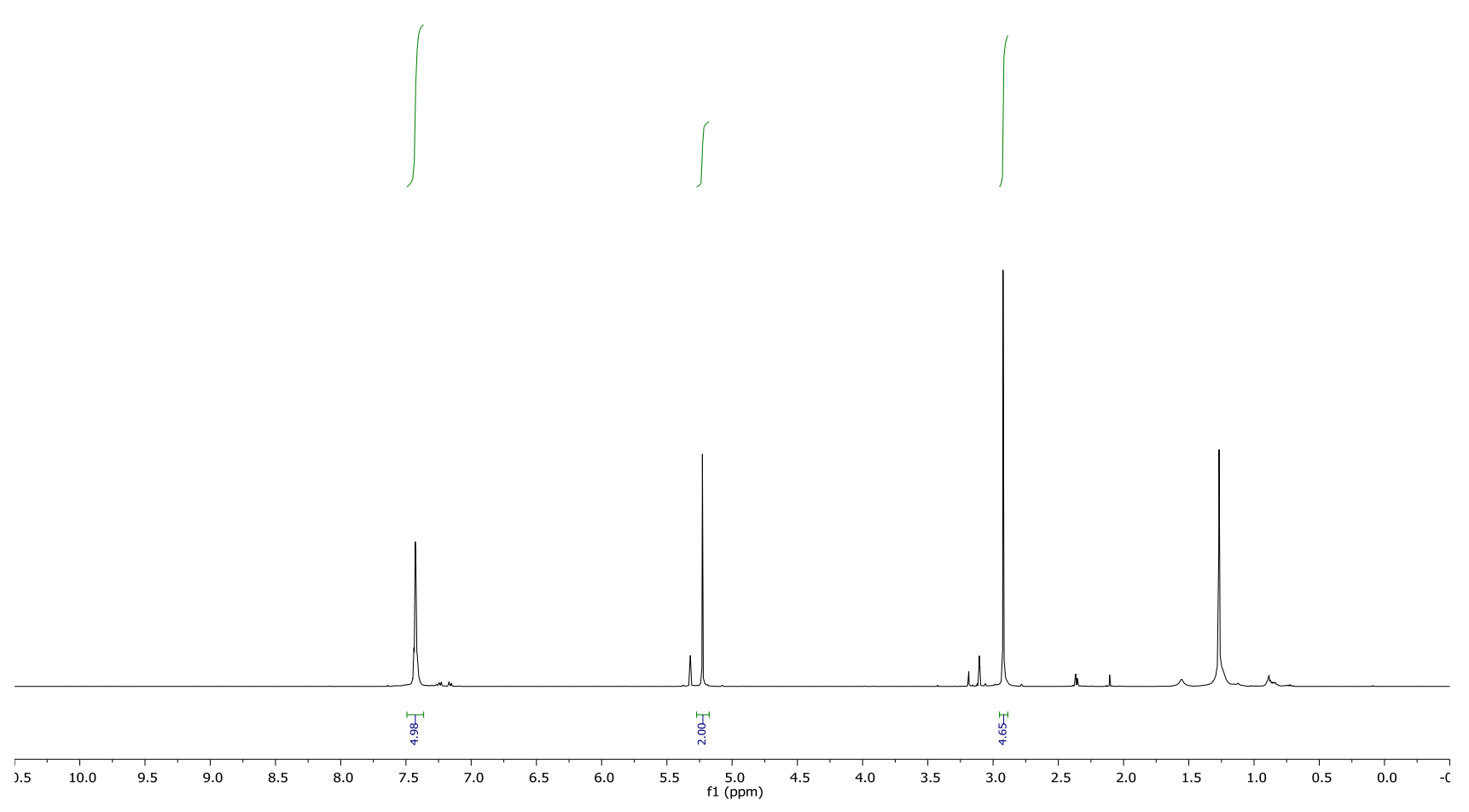

Figure S11: ${ }^{1} \mathrm{H}-\mathrm{NMR}$ to determine the intermolecular KIE. 


\section{Hammett-Analysis}

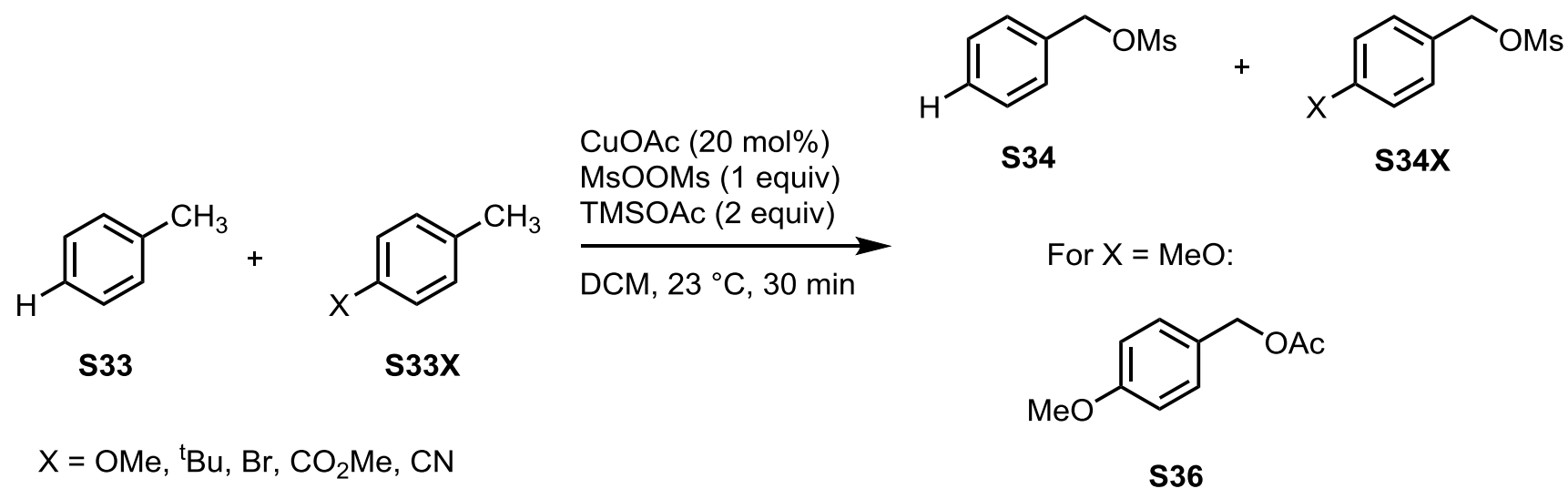

\section{General procedure for substrate competition experiments:}

In an $\mathrm{N}_{2}$-filled glovebox, a $4 \mathrm{~mL}$-scintillation vial was charged with a Teflon-coated magnetic stirring bar, CuOAc (2.45 mg, $20.0 \mu \mathrm{mol}, 20 \mathrm{~mol} \%)$, DCM (0.5 mL), toluene (S33) (53.3 $\mu \mathrm{L}, 46.1 \mathrm{mg}, 0.500 \mathrm{mmol}, 5.00$ equiv), and a para-substituted toluene derivative S33X $(53.1 \mu \mathrm{L}, 50.1 \mathrm{mg}, 0.500 \mathrm{mmol}, 5.00$ equiv). The reaction mixture was cooled down to $-50{ }^{\circ} \mathrm{C}$. MsOOMs (19.0 mg, $0.100 \mathrm{mmol}, 1.00$ equiv) and TMSOAc $\left(30.0 \mu \mathrm{L}, 26.4 \mathrm{mg}, 0.200 \mathrm{mmol}, 2.00\right.$ equiv) were added at $-50^{\circ} \mathrm{C}$. The vial was sealed with a Teflon-lined cap, taken out of the glovebox, allowed to warm to $23^{\circ} \mathrm{C}$, and stirred at $23{ }^{\circ} \mathrm{C}$ for $30 \mathrm{~min}$. Aqueous $\mathrm{Na}_{2} \mathrm{SO}_{3}$ solution $(10 \%(\mathrm{w}: \mathrm{w}), 0.5 \mathrm{~mL})$ was added to the stirring solution. The reaction mixture was transferred to a separation funnel, and the organic and aqueous layer were separated. The aqueous layer was washed with $\mathrm{DCM}(2 \mathrm{~mL})$. The combined organic layers were dried over $\mathrm{MgSO}_{4}$ and concentrated in vacuo. The residue was analyzed by ${ }^{1} \mathrm{H}$-NMR spectroscopy in $\mathrm{CD}_{2} \mathrm{Cl}_{2}$. The resulting ${ }^{1} \mathrm{H}$ resonances of the benzylic protons of the product $\mathbf{S} 34 \mathrm{X}$ (or $\mathbf{S} 36$ in case of $\mathrm{X}=\mathrm{OMe}$ ) were integrated relative to the benzylic ${ }^{1} \mathrm{H}$ proton resonances of tolyl mesylate $(\mathbf{S} 34)(\delta=5.23 \mathrm{ppm})$ to calculate the ratio of products.

Based on the Hammett equation $\left(\log \frac{\mathrm{k}_{\mathrm{X}}}{\mathrm{k}_{\mathrm{H}}}=\sigma \rho, \mathrm{kH}\right.$ is the reference reaction rate of the unsubstituted reactant, and $k_{x}$ that of a substituted reactant), for any two reactions with two aromatic reactants which only differs in the type of substituents, their change in free energy of activation is proportional to the change in Gibbs free energy.

Table S3: Data for Hammett-Plot.

\begin{tabular}{|c|c|c|c|}
\hline Substituent X & $\sigma_{\mathrm{p}}{ }^{+}$ & $\mathrm{k}_{\mathrm{x}} / \mathrm{k}_{\mathrm{H}}$ & $\log \left(\mathrm{k}_{\mathrm{x}} / \mathrm{k}_{\mathrm{H}}\right)$ \\
\hline OMe & -0.78 & 29 & 1.46 \\
\hline${ }^{t} \mathrm{Bu}$ & -0.26 & 2.5 & 0.40 \\
\hline $\mathrm{H}$ & 0.00 & 1.0 & 0.00 \\
\hline $\mathrm{Br}$ & 0.15 & 1.2 & 0.08 \\
\hline
\end{tabular}




\begin{tabular}{|c|c|c|c|}
\hline $\mathrm{CO}_{2} \mathrm{Me}$ & 0.48 & 0.14 & -0.85 \\
\hline $\mathrm{CN}$ & 0.66 & 0.023 & -1.64 \\
\hline
\end{tabular}

The values of $\log \left(\mathrm{k}_{\mathrm{x}} / \mathrm{k}_{\mathrm{H}}\right)$ were plotted versus the $\sigma_{\mathrm{p}}{ }^{+}$value and a linear fit was created to obtain the Hammettslope $\rho=-2$.

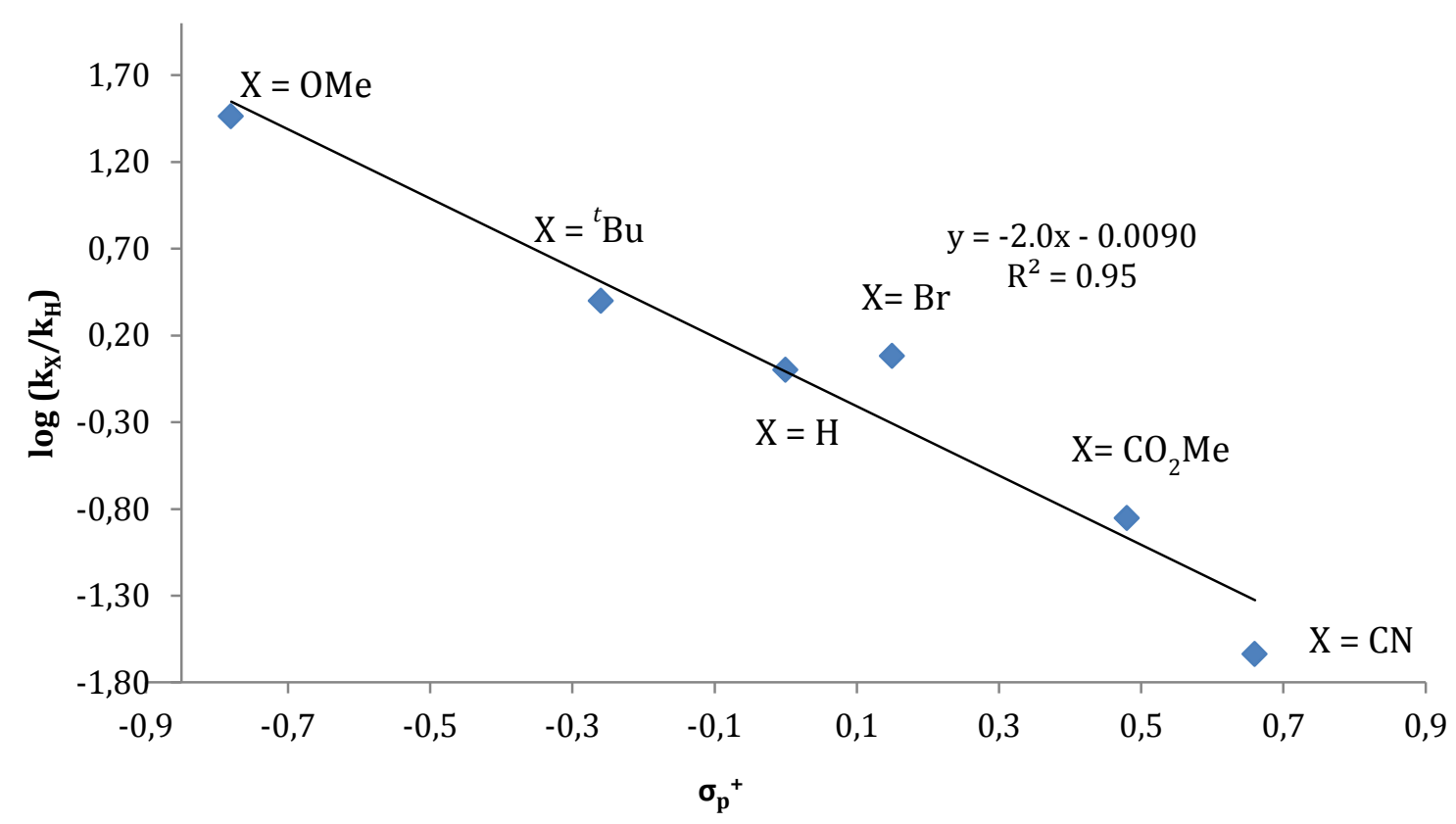

Figure S12: Hammett-Plot for Benzylic Oxidation.

\section{Density Functional Theory Calculation}

\section{Methods}

Unrestricted Kohn-Sham Density Functional Theory (UKS-DFT) calculations were performed on the MaxPlanck-Institut für Kohlenforschung computer cluster using the ORCA program package (Version 4.2.xStable $)^{6}$. Unless denoted otherwise, structural optimizations and frequency calculations to identify all of the stationary points as minima (zero imaginary frequencies) or first-order saddle points (one imaginary frequency), and to obtain thermal and entropic correction to the Gibbs free energy were performed with the B3LYP ${ }^{7,8}$ or PBE0 ${ }^{9,10}$ functionals with D3 dispersion correction ${ }^{11}$ and Becke-Johnson damping (BJ) ${ }^{12}$ along with $\mathrm{RI}$ approximation, utilizing the def2-TZVPP basis set $^{13}$ on all atoms, the $\omega B 97 X-3 D^{14}$ functional along with $\mathrm{RI}$ approximation, utilizing the def2-TZVPP basis set on all atoms, or with the M06-2X ${ }^{15,16}$ functional with D3 dispersion correction along with RI approximation, utilizing the def2-TZVP basis set on all atoms. The libint2 library was used for the computation of 2-el integrals ${ }^{17}$. Solvent effects of dichloromethane were taken into account using the conductor-like polarizable continuum model $(\mathrm{CPCM})^{18}$. Natural bond orbital (NBO) analysis was done by applying the NBO keyword (NBO version $6.0^{19}$ ). Spin-density plots were calculated at the same level as the geometry optimization and plotted using an isosurface value of 0.005 using ChemCraft $1.8^{20}$. Initial geometries of the starting materials (mesyloxyl radical and toluene) and the products 
(methanesulfonic acid and benzyl radical) have been generated using Avogadro $1.2^{21}$ and Chemcraft 1.8. Energy values are given with respect to the thermal free energy correction at $298.15 \mathrm{~K}$.

\section{Geometries}

Ground state geometry optimizations on the initial structures have been carried out in the gas phase at the B3LYP/def2-SVP level with RI approximation. From the optimized structures of reactants and products, an initial guess for a transition state (TS) for the minimum energy pathway has been generated using the nudged elastic band method (NEB) and relaxed surface scans. A TS optimization has been carried out at the B3LYP/def2-SVP level with RI approximation to locate a saddle point (one imaginary frequency). The located TS has been confirmed to lie on the minimum energy path of the desired reaction by following the intrinsic reaction coordinate (IRC) to the starting materials and products utilizing the steepest decent algorithm. The geometry of the TS, the ground state geometry of the reactants, and the ground state geometry of the products have been used as starting points for optimizations with the B3LYP, PBE0, wB97X-3D, and M06-2X functionals according to the specifications given in the "Methods" section.

\section{Functional Evaluation}

Different exchange-correlation functionals have been evaluated for the construction of an energy level diagram and further calculations of chemical properties by comparing the computationally determined KIE value with the experimentally determined KIE value. Computational KIE values have been determined from the Gibbs free activation energy $\left(\Delta G^{\ddagger}\right)$ obtained from the optimized structure of reactants and the TS and the Gibbs free activation energy $\left(\Delta G^{\ddagger}\right)$ obtained from the optimized structure of the deuterium labeled reactants and the deuterium labeled TS utilizing equation $1 .^{22}$

$$
\mathrm{KIE}=\frac{k_{\mathrm{H}}}{k_{\mathrm{D}}}=\exp \left(\frac{\Delta G_{\mathrm{D}}^{\ddagger}-\Delta G^{\ddagger}}{\mathrm{R} T}\right)
$$

In equation $1, \mathrm{R}$ is the gas constant and $T=298 \mathrm{~K}$.

Table S5: Functional evaluation for energy level diagram calculation.

\begin{tabular}{cccccc}
\hline Functional & $\Delta \mathrm{G}^{\ddagger} /\left(\mathrm{kcal} \cdot \mathrm{mol}^{-1}\right)$ & $\Delta \mathrm{G}_{\mathrm{D}}^{\ddagger} /\left(\mathrm{kcal} \cdot \mathrm{mol}^{-1}\right)$ & $\Delta \mathrm{G}^{\ddagger} /\left(\mathrm{kJ} \cdot \mathrm{mol}^{-1}\right)$ & $\Delta \mathrm{G}_{\mathrm{D}}^{\ddagger} /\left(\mathrm{kJ} \cdot \mathrm{mol}^{-1}\right)$ & $\mathrm{KIE}$ \\
\hline PBE0 D3BJ & 0.7 & 1.6 & 2.8 & 6.6 & 4.6 \\
B3LYP D3BJ & 1.2 & 1.5 & 4.8 & 6.2 & 1.8 \\
M06-2X D3 & 3.7 & 3.2 & 15.6 & 13.4 & 0.4 \\
WB97X-D3BJ & 1.7 & 2.3 & 7.2 & 9.7 & 2.7 \\
\hline
\end{tabular}


Based on the agreement of the calculated KIE value with the experimental KIE value of 1.8, further calculations have been carried out with the B3LYP functional.

Energy level diagram and properties of intermediates

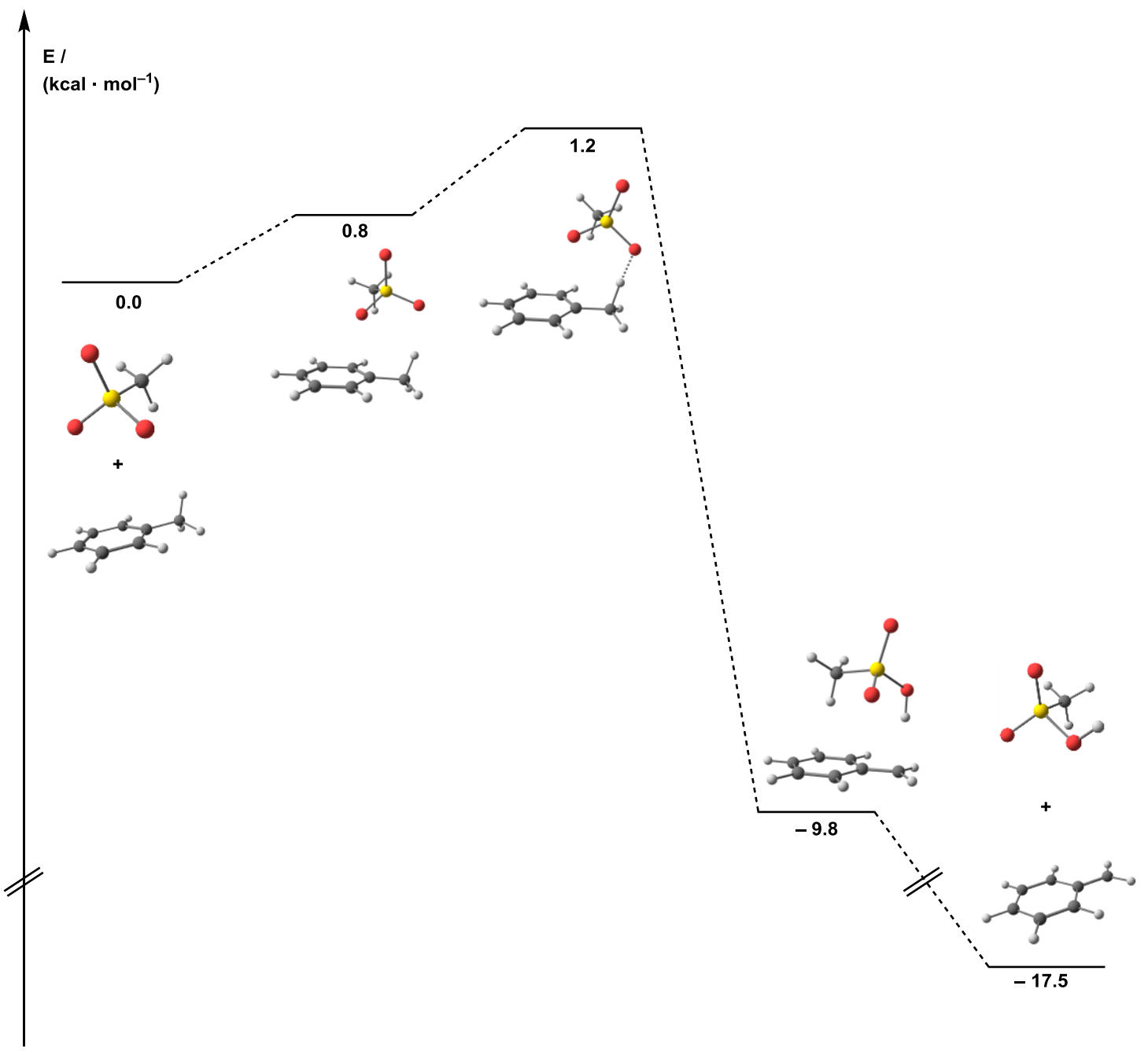

Figure S13: Energy level diagram with optimized structures of stationary points computed at the B3LYP-D3BJ/def2TZVPP level.

Properties of stationary points

Reactant complex: 


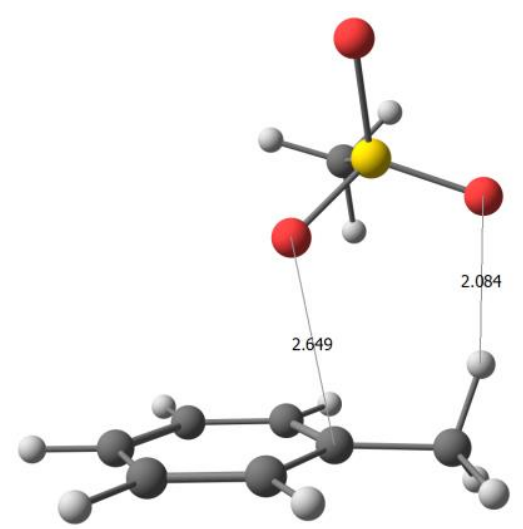

Figure S14: Optimized geometry of reactant complex with bond lengths in $\AA$.

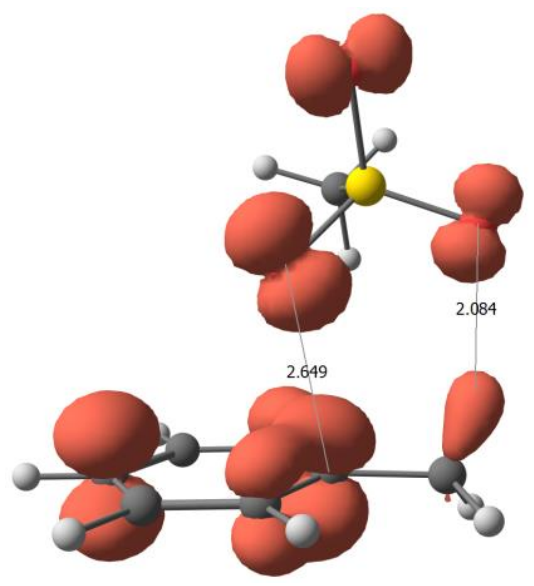

Figure S15: Spin-density plot of reactant complex with bond lengths in $\AA$.

The distances between the mesyloxy oxygen and the ipso-carbon of toluene and another mesyloxy oxygen and the benzylic hydrogen are significantly shorter than the sum of the van-der-Waals radii $\left(r_{w}(O)+r_{w}(C)=\right.$ $3.2 \AA$ and $\left.r_{w}(O)+r_{w}(H)=2.7 \AA\right)^{23}$ indicating bonding interactions. The spin density plot shows partial charge transfer from toluene to the mesyloxylradical.

\section{Transition State:}

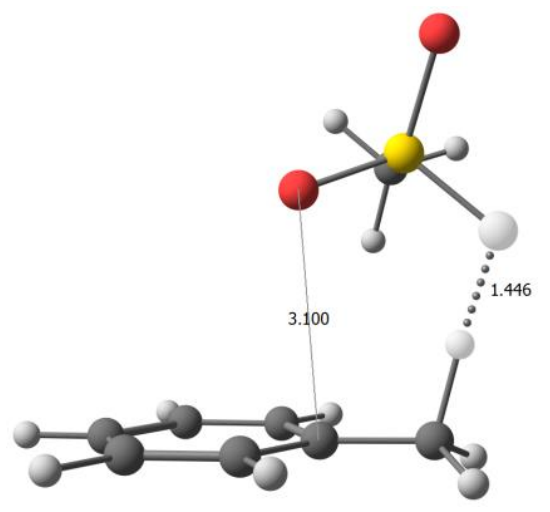

Figure S16: Optimized geometry of the TS. 


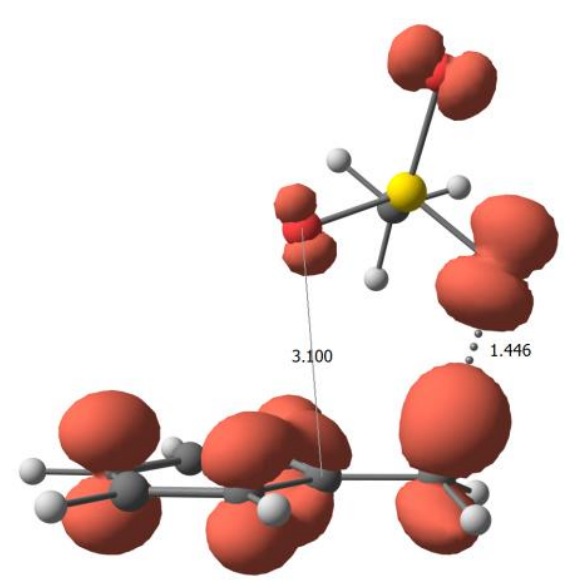

Figure S17: Spin-density plot of the TS.

The distance between the mesyloxy oxygen and the ipso-carbon is still shorter than the sum of the van-derWaals radii $\left(r_{w}(O)+r_{w}(C)=3.2 \AA\right)$, which suggest that some degree of charge transfer interaction is still present in the transition state. Furthermore, more charge has been transferred to the mesyloxyl unit because the spin density on the substrate increases. A low degree of natural spin density is found on the flanking atoms of the hydrogen transfer coordinate $(0.18036$ for $O$ and 0.22595 for $C)$, and a significant positive natural charge of 0.3687 is found on the transferring hydrogen (typically around 0.2 for HAA processes ${ }^{24}$ ). This data is consistent with a proton coupled electron transfer mechanism with partial HAA character. ${ }^{24}$

\section{Products:}

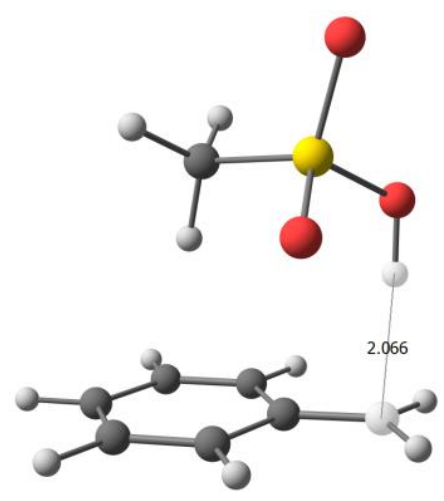

Figure S18: Optimized geometry of the products. 


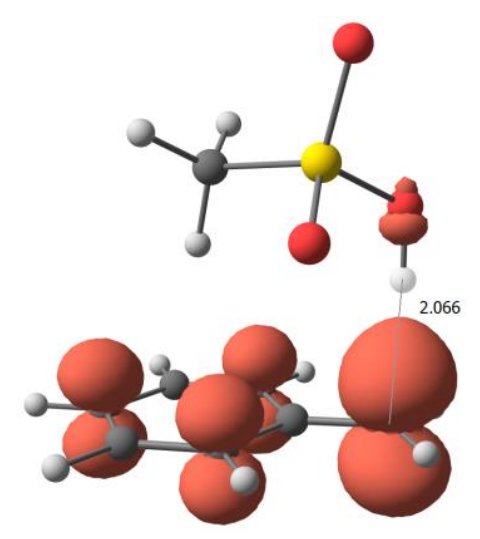

Figure S19: Spin-density plot of the products.

Methanesulfonic acid and benzyl radical have been formed and the spin density is delocalized over the benzyl radical.

Cartesian Coordinates of optimized geometries of stationary points

Optimized structure and cartesian coordinates $(\AA ̊)$ for toluene with B3LYP-D3BJ

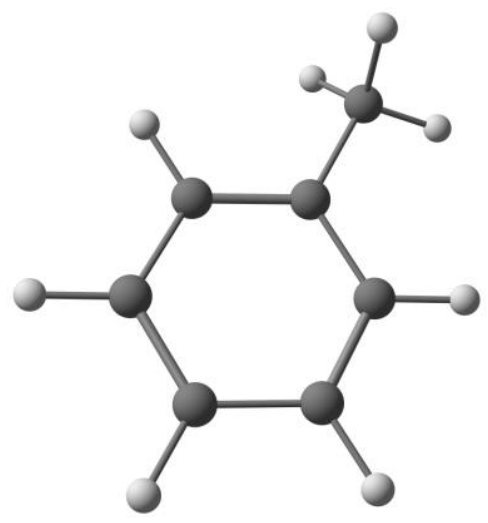

$\begin{array}{lrrr}\text { C } & -2.399575000000 & -0.594778000000 & -0.251467000000 \\ \text { C } & -1.022229000000 & -0.542152000000 & -0.056000000000 \\ \text { C } & -1.175518000000 & 1.800520000000 & 0.427598000000 \\ \text { C } & -2.551466000000 & 1.753669000000 & 0.233841000000 \\ \text { C } & -3.170390000000 & 0.553635000000 & -0.106881000000 \\ \text { H } & -2.868222000000 & -1.532616000000 & -0.520476000000 \\ \text { H } & -0.429771000000 & -1.441111000000 & -0.175188000000 \\ \text { H } & -0.703309000000 & 2.739691000000 & 0.689516000000 \\ \text { H } & -3.140715000000 & 2.654733000000 & 0.346122000000 \\ \text { H } & -4.240722000000 & 0.516357000000 & -0.261374000000 \\ \mathrm{C} & -0.389346000000 & 0.653601000000 & 0.287547000000 \\ \text { H } & 1.321744000000 & 0.721811000000 & 1.590513000000 \\ \mathrm{C} & 1.096705000000 & 0.706383000000 & 0.521254000000 \\ \mathrm{H} & 1.534064000000 & 1.605897000000 & 0.086312000000\end{array}$



$\mathrm{H}$
1.596011000000
$-0.160852000000$
0.090384000000

Optimized structure and cartesian coordinates (Å) for OMs radical with B3LYP-D3BJ

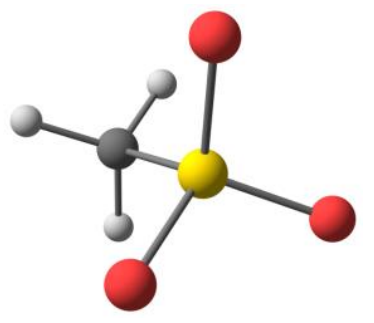

$\begin{array}{lrrr}\text { O } & -1.240611000000 & 0.051299000000 & 2.822975000000 \\ \text { O } & 1.046060000000 & 0.112274000000 & 3.543131000000 \\ \text { S } & -0.339552000000 & 0.421206000000 & 3.921987000000 \\ \text { O } & -0.702223000000 & -0.309360000000 & 5.140338000000 \\ \text { C } & -0.479691000000 & 2.149151000000 & 4.219877000000 \\ \text { H } & -1.520780000000 & 2.361082000000 & 4.450032000000 \\ \text { H } & 0.165534000000 & 2.395358000000 & 5.059404000000 \\ \text { H } & -0.164576000000 & 2.668102000000 & 3.317799000000\end{array}$

Optimized structure and cartesian coordinates $(\AA)$ for the reactant complex with B3LYP-D3BJ
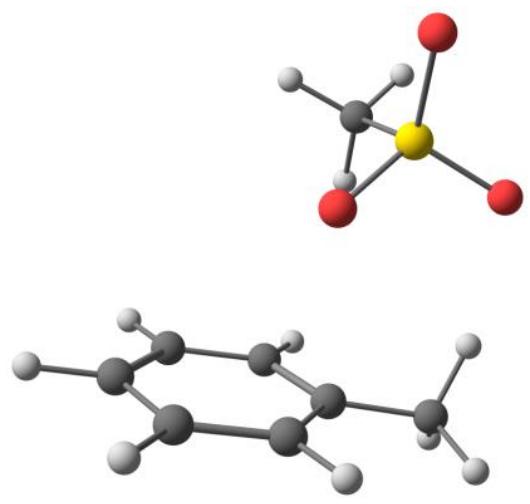
C $\quad-2.452157000000$
$-0.555154000000$
$-0.229763000000$
C $\quad-1.093723000000$
$-0.599861000000$
$-0.044549000000$
C $\quad-1.095771000000$
1.789622000000
0.476886000000
C $\quad-2.454220000000$
1.828810000000
0.292815000000
C -3.141779000000
0.656730000000
$-0.058713000000$
$\mathrm{H} \quad-2.996911000000$
$-1.447221000000$
$-0.504230000000$
H $\quad-0.548692000000$
$-1.525088000000$
$-0.168829000000$
H $\quad-0.549239000000$
2.683776000000
0.743296000000
H $\quad-2.998242000000$
2.754059000000
0.419180000000
$\mathrm{H} \quad-4.213531000000$
0.686899000000
$-0.200165000000$
C $\quad-0.374076000000$
0.572668000000
0.309739000000 


$\begin{array}{lrrr}\mathrm{O} & -1.161710000000 & -0.042606000000 & 2.762705000000 \\ \mathrm{O} & 1.103843000000 & 0.348159000000 & 3.583326000000 \\ \mathrm{H} & 1.336447000000 & 0.586343000000 & 1.525795000000 \\ \mathrm{C} & 1.093063000000 & 0.554961000000 & 0.450179000000 \\ \mathrm{H} & 1.545512000000 & 1.444055000000 & 0.007661000000 \\ \mathrm{H} & 1.536808000000 & -0.344675000000 & 0.029844000000 \\ \mathrm{~S} & -0.325657000000 & 0.390886000000 & 3.908162000000 \\ \mathrm{O} & -0.672366000000 & -0.352793000000 & 5.115538000000 \\ \mathrm{C} & -0.732617000000 & 2.096013000000 & 4.201468000000 \\ \mathrm{H} & -1.798061000000 & 2.163150000000 & 4.406227000000 \\ \mathrm{H} & -0.154978000000 & 2.443162000000 & 5.054649000000 \\ \mathrm{H} & -0.479977000000 & 2.671025000000 & 3.314017000000\end{array}$

Optimized structure and cartesian coordinates $(\AA ̊)$ for the transition state with B3LYP-D3BJ

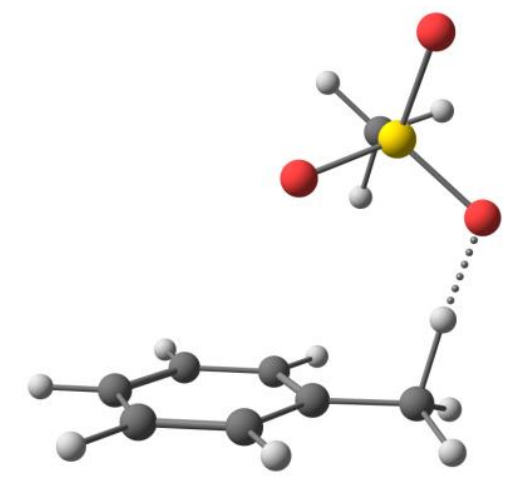
C $\quad-2.451020000000$
$-0.550242000000$
$-0.263839000000$
C $\quad-1.112631000000$
$-0.584693000000$
0.051256000000
C -1.149429000000
1.825151000000
0.439602000000
C -2.489226000000
1.850497000000
0.132273000000
C $\quad-3.147274000000$
0.664098000000
$-0.222288000000$
$\mathrm{H} \quad-2.969308000000$
$-1.457982000000$
$-0.538885000000$
H $\quad-0.566083000000$
$-1.517615000000$
0.034923000000
$\mathrm{H} \quad-0.630144000000$
2.735180000000
0.708432000000
$\mathrm{H} \quad-3.037765000000$
2.781650000000
0.160683000000
$\mathrm{H} \quad-4.201076000000$
0.687325000000
$-0.463507000000$
C $\quad-0.420683000000$
0.606844000000
0.394746000000
O -1.266125000000
$-0.235506000000$
3.255580000000
O $\quad 1.131278000000$
0.246515000000
3.381966000000
H $\quad 1.001613000000$
0.412006000000
1.951544000000
C $\quad 0.972774000000$
0.575079000000
0.736881000000
H 1.505898000000
1.517776000000
0.632787000000 


$\begin{array}{lrrr}\mathrm{H} & 1.527611000000 & -0.289571000000 & 0.381232000000 \\ \mathrm{~S} & -0.209207000000 & 0.312472000000 & 4.089133000000 \\ \mathrm{O} & -0.069546000000 & -0.275448000000 & 5.410227000000 \\ \mathrm{C} & -0.537591000000 & 2.044352000000 & 4.294831000000 \\ \mathrm{H} & -1.487210000000 & 2.143226000000 & 4.815510000000 \\ \mathrm{H} & 0.267636000000 & 2.483069000000 & 4.878393000000 \\ \mathrm{H} & -0.595033000000 & 2.505580000000 & 3.311994000000\end{array}$

Optimized structure and cartesian coordinates $(\AA ̊)$ for the products with B3LYP-D3BJ

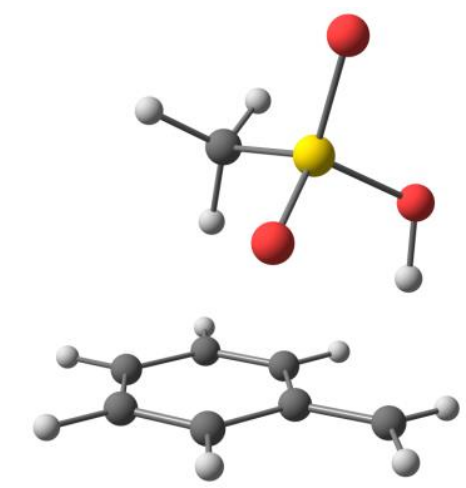

$\begin{array}{lrrr}\text { C } & -2.668120000000 & -0.217807000000 & 0.512266000000 \\ \text { C } & -1.312807000000 & -0.476575000000 & 0.534863000000 \\ \text { C } & -0.873789000000 & 1.836952000000 & -0.082431000000 \\ \text { C } & -2.231975000000 & 2.082280000000 & -0.100859000000 \\ \text { C } & -3.139207000000 & 1.060511000000 & 0.196450000000 \\ \text { H } & -3.370325000000 & -1.006865000000 & 0.745999000000 \\ \text { H } & -0.948216000000 & -1.461389000000 & 0.792779000000 \\ \text { H } & -0.172837000000 & 2.629649000000 & -0.308899000000 \\ \text { H } & -2.597035000000 & 3.070824000000 & -0.345413000000 \\ \text { H } & -4.202346000000 & 1.258963000000 & 0.184035000000 \\ \text { C } & -0.369829000000 & 0.545448000000 & 0.236974000000 \\ \text { O } & -0.051045000000 & -0.833593000000 & 3.661848000000 \\ \text { O } & 1.259176000000 & 1.201910000000 & 3.179580000000 \\ \text { H } & 1.210079000000 & 0.869237000000 & 2.253446000000 \\ \text { C } & 1.011090000000 & 0.293062000000 & 0.279224000000 \\ \text { H } & 1.722523000000 & 1.059598000000 & 0.001444000000 \\ \text { H } & 1.383723000000 & -0.698815000000 & 0.493907000000 \\ \text { S } & 0.142732000000 & 0.527585000000 & 4.090458000000 \\ \text { O } & 0.558418000000 & 0.785585000000 & 5.441655000000 \\ \text { C } & -1.303700000000 & 1.476095000000 & 3.725887000000 \\ \text { H } & -2.099553000000 & 1.095058000000 & 4.361451000000\end{array}$



H $\quad-1.092728000000$
2.518388000000
3.949849000000
H $\quad-1.555331000000$
1.341389000000
2.678153000000

Optimized structure and cartesian coordinates (Å) for MsOH with B3LYP-D3BJ

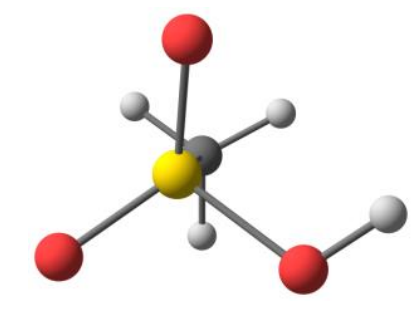
O -0.035207000000
$-0.827947000000$
3.658422000000
O 1.276403000000
1.131346000000
3.181223000000
H 1.685305000000
1.908466000000
3.593622000000
S $\quad 0.147428000000$
0.516684000000
4.128645000000
O $\quad 0.518367000000$
0.745498000000
5.501024000000
C $\quad-1.276606000000$
1.484680000000
3.732802000000
H $\quad-2.095558000000$
1.100689000000
4.336959000000
H $\quad-1.069859000000$
2.522531000000
3.982291000000
H $\quad-1.486036000000$
1.365838000000
2.673304000000

Optimized structure and cartesian coordinates ( $\AA$ ) for benzyl radical with B3LYP-D3BJ

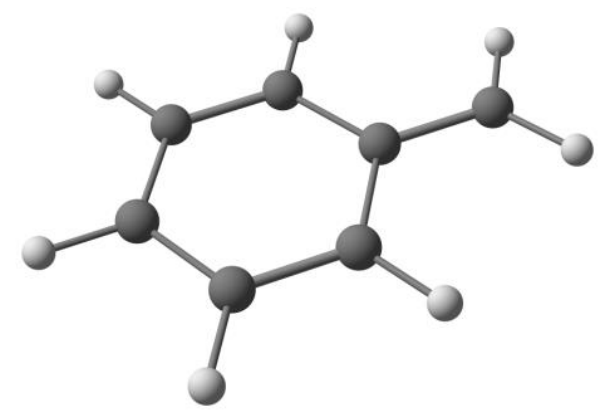
C $\quad-2.668787000000$
$-0.215385000000$
0.516438000000
C $\quad-1.312692000000$
$-0.474296000000$
0.538147000000
C $\quad-0.873973000000$
1.835180000000
$-0.081755000000$
C $\quad-2.232543000000$
2.081117000000
$-0.099951000000$
C $\quad-3.142033000000$
1.061562000000
0.198103000000
$\mathrm{H} \quad-3.370523000000$
$-1.005974000000$
0.748491000000
H $\quad-0.951037000000$
$-1.464065000000$
0.786369000000
$\mathrm{H} \quad-0.174102000000$
2.627637000000
$-0.314504000000$
H $\quad-2.596199000000$
3.069949000000
$-0.347383000000$
$\mathrm{H} \quad-4.205311000000$
1.259797000000
0.183455000000
C $\quad-0.366153000000$
0.544833000000
0.237941000000 


$\begin{array}{llll}\mathrm{C} & 1.011375000000 & 0.286894000000 & 0.254824000000 \\ \mathrm{H} & 1.724739000000 & 1.065404000000 & 0.022999000000 \\ \mathrm{H} & 1.388089000000 & -0.696816000000 & 0.497165000000\end{array}$

Optimized structure and cartesian coordinates $(\AA)$ for the reactant complex with PBE0-D3BJ
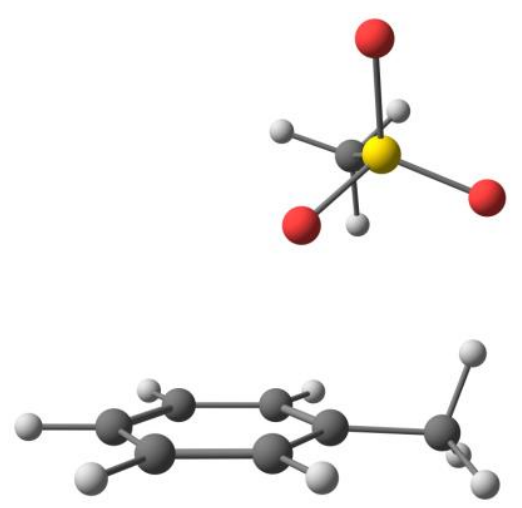

$\begin{array}{lrrr}\text { C } & -2.445166000000 & -0.571343000000 & -0.233501000000 \\ \text { C } & -1.095418000000 & -0.595481000000 & -0.010921000000 \\ \text { C } & -1.136713000000 & 1.803866000000 & 0.454409000000 \\ \text { C } & -2.486628000000 & 1.821295000000 & 0.235006000000 \\ \text { C } & -3.149503000000 & 0.634098000000 & -0.108356000000 \\ \text { H } & -2.973407000000 & -1.476281000000 & -0.503424000000 \\ \text { H } & -0.533849000000 & -1.516844000000 & -0.100331000000 \\ \text { H } & -0.605746000000 & 2.712580000000 & 0.709363000000 \\ \text { H } & -3.046118000000 & 2.743385000000 & 0.323586000000 \\ \text { H } & -4.218746000000 & 0.649389000000 & -0.280005000000 \\ \text { C } & -0.398535000000 & 0.594659000000 & 0.330457000000 \\ \text { O } & -1.197140000000 & -0.008335000000 & 2.772482000000 \\ \text { O } & 1.083880000000 & 0.261337000000 & 3.564015000000 \\ \text { H } & 1.265735000000 & 0.488455000000 & 1.582389000000 \\ \text { C } & 1.056593000000 & 0.592134000000 & 0.497389000000 \\ \text { H } & 1.504870000000 & 1.535852000000 & 0.184391000000 \\ \text { H } & 1.529129000000 & -0.250240000000 & -0.005611000000 \\ \text { S } & -0.333678000000 & 0.375705000000 & 3.902968000000 \\ \text { O } & -0.695046000000 & -0.342457000000 & 5.112050000000 \\ \text { C } & -0.643006000000 & 2.086286000000 & 4.198721000000 \\ \text { H } & -1.704192000000 & 2.213060000000 & 4.403417000000 \\ \text { H } & -0.048028000000 & 2.401008000000 & 5.054024000000 \\ \text { H } & -0.357287000000 & 2.650535000000 & 3.312727000000\end{array}$

Optimized structure and cartesian coordinates $(\AA \AA)$ for the transition state with PBE0-D3BJ 


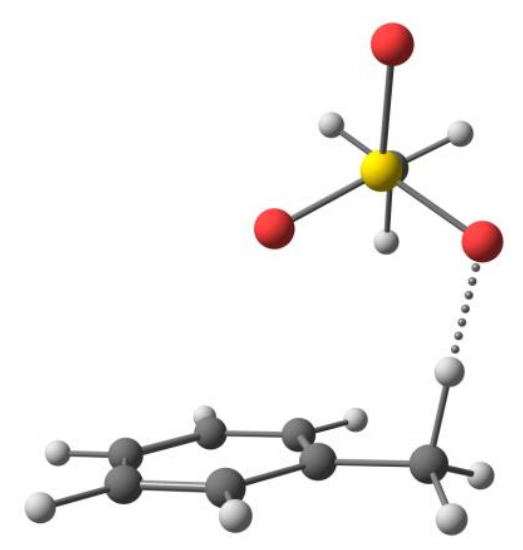

$\begin{array}{lrrr}\text { C } & -2.449372000000 & -0.546996000000 & -0.213695000000 \\ \text { C } & -1.111186000000 & -0.584567000000 & 0.081186000000 \\ \text { C } & -1.129264000000 & 1.830026000000 & 0.443711000000 \\ \text { C } & -2.468402000000 & 1.858693000000 & 0.158575000000 \\ \text { C } & -3.136087000000 & 0.671025000000 & -0.173024000000 \\ \text { H } & -2.978625000000 & -1.454835000000 & -0.471826000000 \\ \text { H } & -0.565884000000 & -1.519974000000 & 0.066180000000 \\ \text { H } & -0.597530000000 & 2.740697000000 & 0.691508000000 \\ \text { H } & -3.014469000000 & 2.792876000000 & 0.184425000000 \\ \text { H } & -4.195099000000 & 0.697800000000 & -0.397731000000 \\ \text { C } & -0.409027000000 & 0.607464000000 & 0.400600000000 \\ \text { O } & -1.209525000000 & -0.221207000000 & 3.157913000000 \\ \text { O } & 1.151215000000 & 0.276877000000 & 3.441792000000 \\ \text { H } & 1.044757000000 & 0.437745000000 & 1.879685000000 \\ \text { C } & 0.993935000000 & 0.574427000000 & 0.710193000000 \\ \text { H } & 1.518911000000 & 1.515307000000 & 0.547590000000 \\ \text { H } & 1.527609000000 & -0.292606000000 & 0.324845000000 \\ \text { S } & -0.206628000000 & 0.313578000000 & 4.061968000000 \\ \text { O } & -0.170247000000 & -0.301480000000 & 5.372649000000 \\ \text { C } & -0.575365000000 & 2.021184000000 & 4.292326000000 \\ \text { H } & -1.557538000000 & 2.093991000000 & 4.756102000000 \\ \text { H } & 0.184876000000 & 2.457180000000 & 4.937334000000 \\ \text { H } & -0.579599000000 & 2.512557000000 & 3.321167000000\end{array}$

Optimized structure and cartesian coordinates $(\AA)$ for the reactant complex with wB97X-D3 

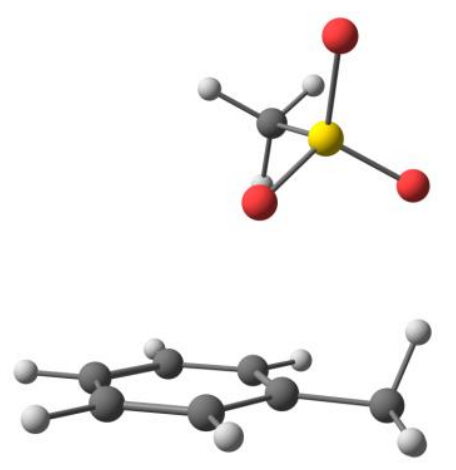

$\begin{array}{lrrr}\text { C } & -2.486940000000 & -0.459102000000 & -0.149122000000 \\ \text { C } & -1.139696000000 & -0.620398000000 & -0.053326000000 \\ \text { C } & -0.900478000000 & 1.780907000000 & 0.447231000000 \\ \text { C } & -2.248230000000 & 1.933304000000 & 0.352195000000 \\ \text { C } & -3.052559000000 & 0.814906000000 & 0.057967000000 \\ \text { H } & -3.130009000000 & -1.297472000000 & -0.376461000000 \\ \text { H } & -0.679225000000 & -1.588057000000 & -0.198181000000 \\ \text { H } & -0.255224000000 & 2.618922000000 & 0.675820000000 \\ \text { H } & -2.709109000000 & 2.899169000000 & 0.504090000000 \\ \text { H } & -4.126092000000 & 0.935530000000 & -0.008168000000 \\ \mathrm{C} & -0.300464000000 & 0.495003000000 & 0.246931000000 \\ \text { O } & -0.898854000000 & -0.139239000000 & 2.775892000000 \\ \text { O } & 1.108603000000 & 1.052321000000 & 3.444215000000 \\ \text { H } & 1.447986000000 & 0.502522000000 & 1.361961000000 \\ \text { C } & 1.158956000000 & 0.357862000000 & 0.309605000000 \\ \text { H } & 1.644132000000 & 1.162433000000 & -0.247064000000 \\ \text { H } & 1.505052000000 & -0.612838000000 & -0.034338000000 \\ \text { S } & -0.192405000000 & 0.542494000000 & 3.866872000000 \\ \text { O } & -0.131850000000 & -0.266387000000 & 5.073852000000 \\ \text { C } & -1.166954000000 & 1.963016000000 & 4.274655000000 \\ \text { H } & -2.145601000000 & 1.629082000000 & 4.611986000000 \\ \text { H } & -0.661697000000 & 2.509646000000 & 5.068008000000 \\ \text { H } & -1.267342000000 & 2.589037000000 & 3.390626000000\end{array}$

Optimized structure and cartesian coordinates $(\AA)$ for the transition state with wB97X-D3 


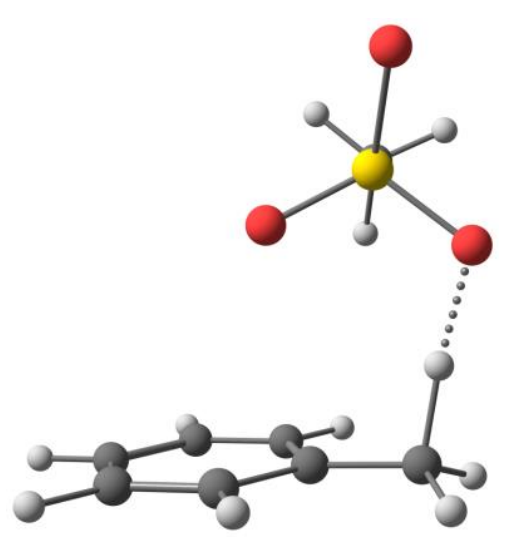

$\begin{array}{lrrr}\text { C } & -2.453328000000 & -0.558785000000 & -0.207321000000 \\ \text { C } & -1.114262000000 & -0.607672000000 & 0.066302000000 \\ \text { C } & -1.102409000000 & 1.821518000000 & 0.386160000000 \\ \text { C } & -2.442552000000 & 1.857158000000 & 0.121746000000 \\ \text { C } & -3.125847000000 & 0.669146000000 & -0.177893000000 \\ \text { H } & -2.998777000000 & -1.463538000000 & -0.437713000000 \\ \text { H } & -0.580178000000 & -1.548677000000 & 0.064667000000 \\ \text { H } & -0.556996000000 & 2.728146000000 & 0.615424000000 \\ \text { H } & -2.980678000000 & 2.794932000000 & 0.141566000000 \\ \text { H } & -4.187376000000 & 0.702047000000 & -0.386342000000 \\ \text { C } & -0.390726000000 & 0.586045000000 & 0.354597000000 \\ \text { O } & -1.234691000000 & -0.166664000000 & 3.160872000000 \\ \text { O } & 1.117248000000 & 0.396800000000 & 3.347829000000 \\ \text { H } & 0.989843000000 & 0.462958000000 & 1.887107000000 \\ \text { C } & 0.997307000000 & 0.545520000000 & 0.663859000000 \\ \text { H } & 1.545552000000 & 1.473677000000 & 0.518621000000 \\ \text { H } & 1.533211000000 & -0.350435000000 & 0.362500000000 \\ \text { S } & -0.205949000000 & 0.348084000000 & 4.042379000000 \\ \text { O } & -0.085136000000 & -0.331177000000 & 5.311790000000 \\ \text { C } & -0.604194000000 & 2.032933000000 & 4.383737000000 \\ \text { H } & -1.551962000000 & 2.057945000000 & 4.916291000000 \\ \text { H } & 0.186347000000 & 2.459820000000 & 4.996035000000 \\ \text { H } & -0.686991000000 & 2.569983000000 & 3.441261000000\end{array}$

Optimized structure and cartesian coordinates $(\AA ̊)$ for the reactant complex with M06-2X D3 

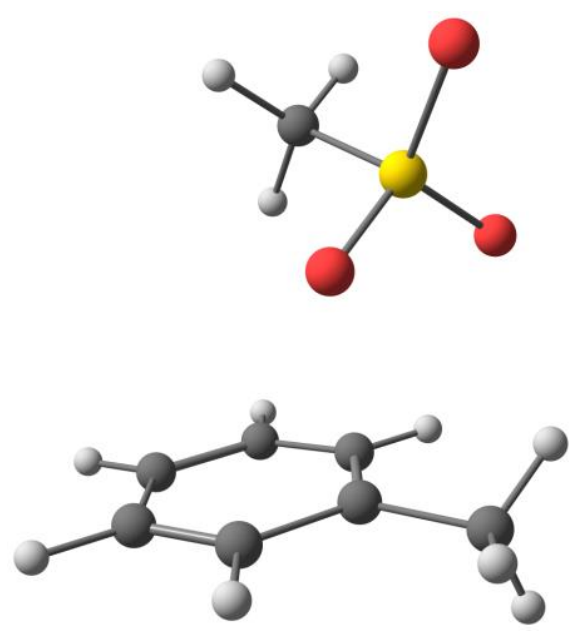

$\begin{array}{lrrr}\text { C } & -2.539556000000 & -0.288675000000 & -0.059714000000 \\ \text { C } & -1.216128000000 & -0.597328000000 & 0.009278000000 \\ \text { C } & -0.701387000000 & 1.767890000000 & 0.499334000000 \\ \text { C } & -2.027872000000 & 2.067664000000 & 0.429532000000 \\ \text { C } & -2.957049000000 & 1.043407000000 & 0.156887000000 \\ \text { H } & -3.276443000000 & -1.050331000000 & -0.271688000000 \\ \text { H } & -0.865301000000 & -1.609605000000 & -0.141152000000 \\ \text { H } & 0.040515000000 & 2.522950000000 & 0.718802000000 \\ \text { H } & -2.376127000000 & 3.079089000000 & 0.584601000000 \\ \text { H } & -4.011257000000 & 1.281101000000 & 0.112637000000 \\ \text { C } & -0.253350000000 & 0.419866000000 & 0.296920000000 \\ \text { O } & -0.523228000000 & -0.166728000000 & 2.751480000000 \\ \text { O } & 0.792748000000 & 1.825998000000 & 3.165639000000 \\ \text { H } & 1.675219000000 & 0.649848000000 & 1.104437000000 \\ \text { C } & 1.188621000000 & 0.133873000000 & 0.274768000000 \\ \text { H } & 1.604229000000 & 0.551052000000 & -0.651817000000 \\ \text { H } & 1.396380000000 & -0.932611000000 & 0.304492000000 \\ \text { S } & -0.077171000000 & 0.814374000000 & 3.747266000000 \\ \text { O } & 0.484542000000 & 0.179878000000 & 4.926681000000 \\ \text { C } & -1.534201000000 & 1.655088000000 & 4.281040000000 \\ \text { H } & -2.212447000000 & 0.923612000000 & 4.714780000000 \\ \text { H } & -1.247266000000 & 2.397058000000 & 5.022953000000 \\ \text { H } & -1.991472000000 & 2.135193000000 & 3.418089000000\end{array}$

Optimized structure and cartesian coordinates $(\AA)$ for the transition state with M06-2X D3 


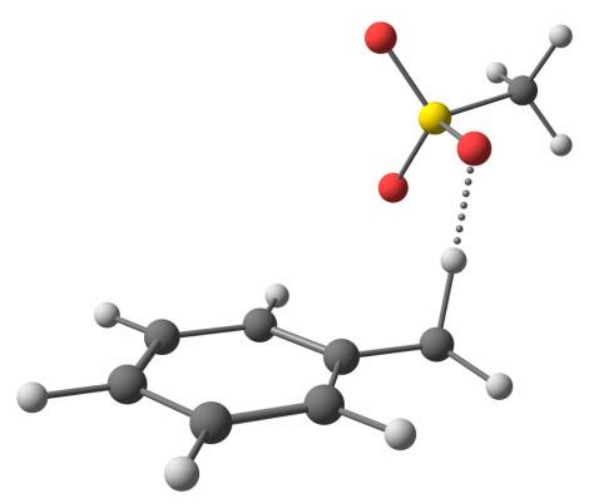

$\begin{array}{lrrr}\text { C } & -2.098220000000 & -0.962812000000 & -1.150436000000 \\ \text { C } & -0.929722000000 & -0.764978000000 & -0.472920000000 \\ \text { C } & -1.765258000000 & 1.414455000000 & 0.312317000000 \\ \text { C } & -2.932834000000 & 1.204904000000 & -0.364997000000 \\ \text { C } & -3.106409000000 & 0.020314000000 & -1.104168000000 \\ \text { H } & -2.258753000000 & -1.865744000000 & -1.722955000000 \\ \text { H } & -0.139680000000 & -1.504228000000 & -0.491782000000 \\ \text { H } & -1.604367000000 & 2.305379000000 & 0.906167000000 \\ \text { H } & -3.727126000000 & 1.937545000000 & -0.336362000000 \\ \text { H } & -4.032676000000 & -0.143519000000 & -1.638485000000 \\ \text { C } & -0.712973000000 & 0.446667000000 & 0.252302000000 \\ \text { O } & -0.529441000000 & 2.620833000000 & 3.288814000000 \\ \text { O } & -0.107438000000 & 0.260452000000 & 3.610103000000 \\ \text { H } & 0.237684000000 & 0.419676000000 & 2.070069000000 \\ \text { C } & 0.513994000000 & 0.679909000000 & 0.947418000000 \\ \text { H } & 0.775219000000 & 1.730874000000 & 1.069736000000 \\ \text { H } & 1.339795000000 & 0.032070000000 & 0.667820000000 \\ \text { S } & -0.536376000000 & 1.529072000000 & 4.245143000000 \\ \text { O } & -1.789209000000 & 1.368157000000 & 4.952640000000 \\ \text { C } & 0.691720000000 & 1.884985000000 & 5.456136000000 \\ \text { H } & 0.410207000000 & 2.809876000000 & 5.954816000000 \\ \text { H } & 0.718404000000 & 1.061588000000 & 6.166191000000 \\ \text { H } & 1.650916000000 & 1.994286000000 & 4.955907000000\end{array}$

\section{X-RAY CRYSTALLOGRAPHIC ANALYSIS}

Hydroxy-phenylalanine derivative 14 (CCDC 1944992)

Crystals suitable for single crystal x-ray diffraction were obtained by cooling a DCM ( 10 mg in $1 \mathrm{~mL})$ solution of 14 to $-20^{\circ} \mathrm{C}$ by pentane diffusion into it. A crystal was mounted on a nylon loop using perfluoropolyether, and transferred to a Bruker AXS Enraf-Nonius KappaCCD diffractometer (either MoKa radiation, $\lambda=0.71073 \AA$ 
or CuKa radiation, $\lambda=1.54178 \AA$ ) equipped with an Oxford Cryosystems nitrogen flow apparatus. The sample was held at $100(2) \mathrm{K}$ during the experiment. The structures were solved by the direct methods procedure and refined by least-squares methods against $F^{2}$ using SHELXS and SHELXL. ${ }^{5}$ Non-hydrogen atoms were refined anisotropically, and hydrogen atoms were allowed to ride on the respective atoms.

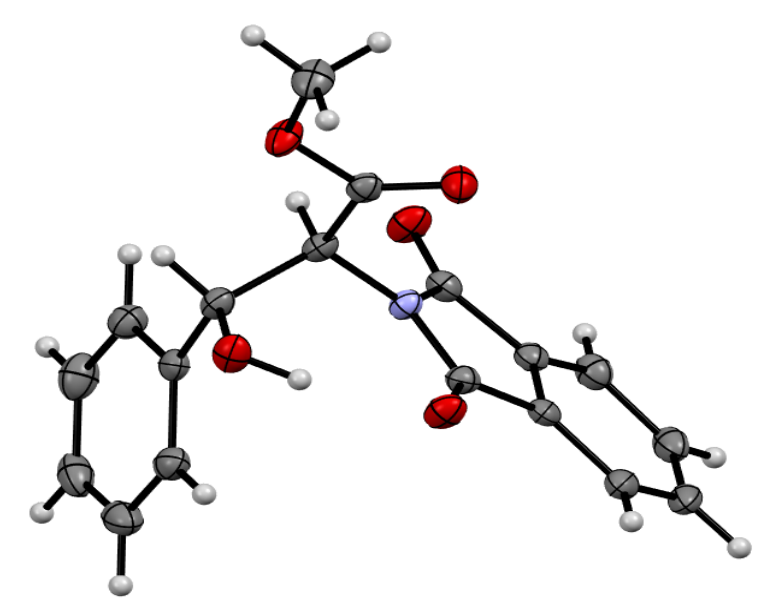

Table S6. Crystal data and structure refinement for 12510 .

Identification code

Empirical formula

Color

Formula weight

Temperature

Wavelength

Crystal system

Space group

Unit cell dimensions
12510

$\mathrm{C}_{18} \mathrm{H}_{15} \mathrm{~N} \mathrm{O}_{5}$

colourless

$325.31 \mathrm{~g} \cdot \mathrm{mol}^{-1}$

100(2) K

$1.54178 \AA$

TRIGONAL

P322,

$$
\begin{array}{ll}
\mathrm{a}=11.8237(3) \AA & \alpha=90^{\circ} . \\
\mathrm{b}=11.8237(3) \AA & \beta=90^{\circ} .
\end{array}
$$




$$
\mathrm{c}=19.0470(5) \AA \quad \gamma=120^{\circ} .
$$

Volume

Z

Density (calculated)

Absorption coefficient

$\mathrm{F}(000)$

Crystal size

$\theta$ range for data collection

Index ranges

Reflections collected

Independent reflections

Reflections with $\mathrm{I}>2 \sigma(\mathrm{I})$

Completeness to $\theta=63.626^{\circ}$

Absorption correction

Max. and min. transmission

Refinement method

Data / restraints / parameters

Goodness-of-fit on $\mathrm{F}^{2}$

Final $R$ indices $[\mathrm{I}>2 \sigma(\mathrm{I})]$

$\mathrm{R}$ indices (all data)

Absolute structure parameter

Largest diff. peak and hole
2306.02(13) $\AA^{3}$

6

$1.406 \mathrm{Mg} \cdot \mathrm{m}^{-3}$

$0.864 \mathrm{~mm}^{-1}$

$1020 \mathrm{e}$

$0.187 \times 0.146 \times 0.140 \mathrm{~mm}^{3}$

4.318 to $63.626^{\circ}$.

$-13 \leq \mathrm{h} \leq 13,-13 \leq \mathrm{k} \leq 13,-19 \leq 1 \leq 21$

54950

$2528\left[\mathrm{R}_{\mathrm{int}}=0.0431\right]$

2456

$99.3 \%$

Gaussian

0.95 and 0.89

Full-matrix least-squares on $\mathrm{F}^{2}$

$2528 / 0 / 230$

1.055

$$
\begin{array}{ll}
\mathrm{R}_{1}=0.0227 & \mathrm{wR} \mathrm{R}^{2}=0.0562 \\
\mathrm{R}_{1}=0.0240 & \mathrm{wR}^{2}=0.0568
\end{array}
$$

0.04(4)

0.1 and $-0.2 \mathrm{e} \cdot \AA^{-3}$

CCDC \#1944992 (14) contains the supplementary crystallographic data for this structure.

The data can be obtained free of charge from The Cambridge Crystallographic Data Centre via www.ccdc.cam.ac.uk/structures. 
4-Hydroxy (phenyl)methyl-3-propionyl-2-oxazolidinone 16A (CCDC 1956799)

Experimental procedure for synthesizing benzoyl ester derivative 16A:<smiles>CCC(=O)N1C(=O)OCC1(C)C(O)c1ccccc1</smiles>

16

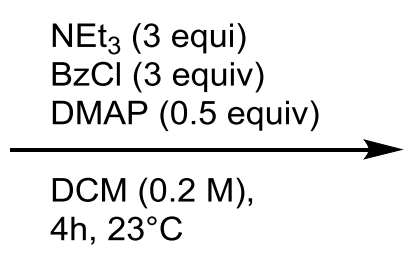

$4 \mathrm{~h}, 23^{\circ} \mathrm{C}$<smiles>CCC(=O)OC(c1ccccc1)[C@H]1COC(=O)N1C(=O)c1ccccc1</smiles>

$16 \mathrm{~A}$

Under an atmosphere of argon, a flame-dried $5 \mathrm{~mL}$ round bottom flask was charged with a teflon-coated stirring bar and 16 (20.0 mg, $0.080 \mathrm{mmol}, 1.00$ equiv), and DCM (1.5 mL), triethylamine (33.6 $\mu \mathrm{L}, 24.4 \mathrm{mg}$, 0.240 mmol. 3.00 equiv), BzCl (28 $\mu \mathrm{L}, 33.9 \mathrm{mg}, 0.240 \mathrm{mmol}, 3$ equiv), and DMAP (5.0 mg, $0.04 \mathrm{mmol}, 0.5$ equiv). The reaction mixture was stirred at $23{ }^{\circ} \mathrm{C}$ for $4 \mathrm{~h}$. The solvent was evaporated under reduced pressure. The residue was purified by column chromatography on silica gel eluting with a solvent mixture of ethyl acetate/isohexane $(5: 95(\mathrm{v} / \mathrm{v}))$ to afford $19.0 \mathrm{mg}$ of the title compound as a colorless solid.

\section{NMR Spectroscopy:}

${ }^{1}$ H NMR $\left(500 \mathrm{MHz}, \mathrm{CDCl}_{3}, 25{ }^{\circ} \mathrm{C}, \delta\right): 7.62-7.58(\mathrm{~m}, 2 \mathrm{H}), 7.55(\mathrm{t}, J=7.5 \mathrm{~Hz}, 1 \mathrm{H}), 7.45-7.35(\mathrm{~m}, 7 \mathrm{H}), 6.29$ $(\mathrm{d}, J=6.6 \mathrm{~Hz}, 1 \mathrm{H}), 5.22(\mathrm{~m}, J=8.4,6.6,4.0 \mathrm{~Hz}, 1 \mathrm{H}), 4.47-4.34(\mathrm{~m}, 2 \mathrm{H}), 2.33(\mathrm{qd}, J=7.7,3.8 \mathrm{~Hz}, 2 \mathrm{H}), 1.07$ (t, $J=7.5 \mathrm{~Hz}, 3 \mathrm{H}$ ).

\section{X-ray analysis:}

Crystals suitable for single crystal $x$-ray diffraction were obtained by cooling an EtOAc ( 10 mg in $1 \mathrm{~mL})$ solution of 14 to $-20^{\circ} \mathrm{C}$ by pentane diffusion into the solution. A crystal was mounted on a nylon loop using perfluoropolyether, and transferred to a Bruker-AXS Kappa Mach3 APEX-II-diffractometer with an $0.2 \times 2 \mathrm{~mm}^{2}$ focus rotating anode as the diffraction radiation source at $100(2) \mathrm{K}$ The diffraction measurement method was CCD $\Phi$ and the radiation type was CulKa with a wavelength of $1.54178 \AA$. The sample was held at 100 (2) $\mathrm{K}$ during the experiment. The structures were solved by the direct methods procedure and refined by leastsquares methods against $F^{2}$ using SHELXS and SHELXL. ${ }^{5}$ Non-hydrogen atoms were refined anisotropically, and hydrogen atoms were allowed to ride on respective atoms. 


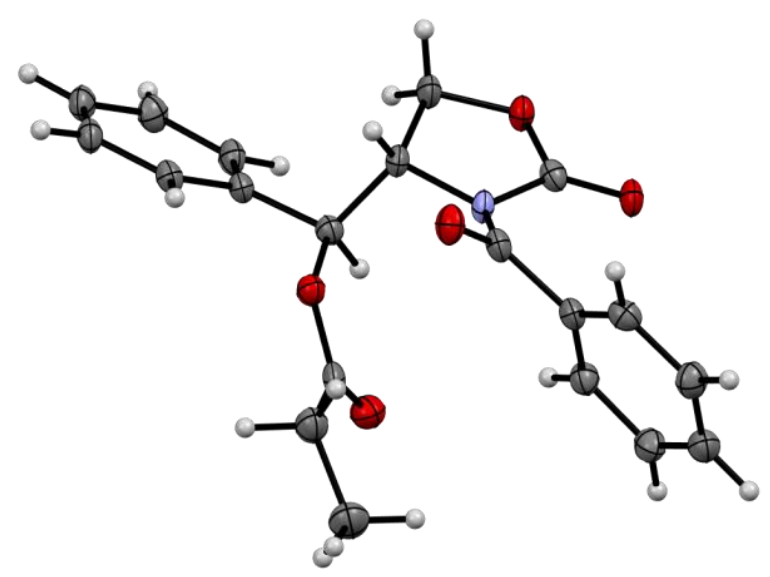

Table S7.Crystal data and structure refinement.for 12656

Identification code

12656

Empirical formula

$\mathrm{C}_{20} \mathrm{H}_{19} \mathrm{~N} \mathrm{O}_{5}$

Color

colourless

Formula weight

$353.36 \mathrm{~g} \cdot \mathrm{mol}^{-1}$

Temperature

100(2) K

Wavelength

$1.54178 \AA$

Crystal system

MONOCLINIC

Space group

P2 ${ }_{1}$, (no. 4)

Unit cell dimensions

$$
\begin{array}{ll}
\mathrm{a}=11.3601(7) \AA & \alpha=90^{\circ} . \\
\mathrm{b}=5.8169(3) \AA & \beta=107.480(3)^{\circ} . \\
\mathrm{c}=13.5193(9) \AA & \gamma=90^{\circ} .
\end{array}
$$

Volume

852.11(9) $\AA^{3}$

Z

2

Density (calculated)

$1.377 \mathrm{Mg} \cdot \mathrm{m}^{-3}$

Absorption coefficient

$0.822 \mathrm{~mm}^{-1}$

$\mathrm{F}(000)$

$372 \mathrm{e}$ 
Crystal size

$\theta$ range for data collection

Index ranges

Reflections collected

Independent reflections

Reflections with $\mathrm{I}>2 \sigma(\mathrm{I})$

Completeness to $\theta=68.000^{\circ}$

Absorption correction

Max. and min. transmission

Refinement method

Data / restraints / parameters

Goodness-of-fit on $\mathrm{F}^{2}$

Final $\mathrm{R}$ indices $[\mathrm{I}>2 \sigma(\mathrm{I})]$

$\mathrm{R}$ indices (all data)

Absolute structure parameter

Extinction coefficient

Largest diff. peak and hole
$0.320 \times 0.068 \times 0.051 \mathrm{~mm}^{3}$

3.427 to $72.478^{\circ}$.

$-13 \leq \mathrm{h} \leq 13,-5 \leq \mathrm{k} \leq 6,-16 \leq 1 \leq 16$

31177

$2998\left[\mathrm{R}_{\mathrm{int}}=0.0679\right]$

2528

$97.0 \%$

Gaussian

0.98 and 0.91

Full-matrix least-squares on $\mathrm{F}^{2}$

$2998 / 1 / 245$

1.141

$\mathrm{R}_{1}=0.0416 \quad \mathrm{wR}^{2}=0.1048$

$\mathrm{R}_{1}=0.0581 \quad \mathrm{wR}^{2}=0.1115$

$0.1(3)$

$0.0105(18)$

0.2 and $-0.25 \mathrm{e} \cdot \AA^{-3}$

CCDC \#1956799 (14) contains the supplementary crystallographic data for this structure.

The data can be obtained free of charge from The Cambridge Crystallographic Data Centre via www.ccdc.cam.ac.uk/structures.

\section{REFERENCES}

(1) Shriver, D. F.; A., M.; Drezdzon, D. F. S.; Drezdzon, M. A.; Drezdzon, M. A., The Manipulation of AirSensitive Compounds. Wiley: 1986.

(2) Fulmer, G. R.; Miller, A. J. M.; Sherden, N. H.; Gottlieb, H. E.; Nudelman, A.; Stoltz, B. M.; Bercaw, J. E.; Goldberg, K. I. NMR Chemical Shifts of Trace Impurities: Common Laboratory Solvents, Organics, and Gases in Deuterated Solvents Relevant to the Organometallic Chemist. Organometallics 2010, 29, 2176 2179.

(3) Harris, R. K.; Becker, E. D.; Cabral de Menezes, S. M.; Goodfellow, R.; Granger, P. NMR Nomenclature: Nuclear Spin Properties and Conventions for Chemical Shifts. IUPAC Recommendations 2001. Solid State 
Nucl. Magn. Reson. 2002, 22, 458-483.

(4) Börgel, J.; Tanwar, L.; Berger, F.; Ritter, T. Late-Stage Aromatic C-H Oxygenation. J. Am. Chem. Soc. 2018, 140, 16026-16031.

(5) Sheldrick, G. M. Crystal structure refinement with SHELXL Acta Crystallogr. Sect. A: Found. Crystallogr. 2008, 64, 112-122.

(6) Neese, F. The ORCA program system. WIREs Comput. Mol. Sci. 2012, 2, 73-78.

(7) Becke, A. D. Density-functional thermochemistry. III. The role of exact exchange, J. Chem. Phys. 1993, 98, 5648-5652.

(8) Lee, C.; Yang, W; Parr, R. G; Development of the Colle-Salvetti correlation-energy formula into a functional of the electron density. Physical Review B 1988, 37, 785-789.

(9) Perdew, J. P.; Ernzerhof, M.; Burke, K. Rationale for mixing exact exchange with density functional approximations. J. Chem. Phys. 1996, 105, 9982-9985.

(10) Adamo, C; Barone, V; Toward reliable density functional methods without adjustable parameters: The PBE0 model. J. Chem. Phys. 1999, 110, 6158-6170.

(11) Grimme, S.; Antony, J.; Ehrlich, S; Krieg, H. A. Consistent and accurate ab initio parametrization of density functional dispersion correction (DFT-D) for the 94 elements H-Pu, J. Chem. Phys. 2010, 132, 154104.

(12) Grimme, S.; Ehrlich, S; Goerigk, L. Effect of the damping function in dispersion corrected density functional theory. J. Comput. Chem. 2011, 32, 1456-1465.

(13) Weigend, F.; Ahlrichs, R. Balanced basis sets of split valence, triple zeta valence and quadruple zeta valence quality for $\mathrm{H}$ to $\mathrm{Rn}$ : Design and assessment of accuracy, Phys. Chem. Chem. Phys. 2005, 7, 32973305.

(14) Chai, J. D.; Head-Gordon, M. Long-range corrected hybrid density functionals with damped atom-atom dispersion corrections. Phys. Chem. Chem. Phys. 2008, 10, 6615.

(15) Zhao, Y. ; Truhlar, D.G. The M06 suite of density functionals for main group thermochemistry, thermochemical kinetics, noncovalent interactions, excited states, and transition elements: two new functionals and systematic testing of four M06-class functionals and 12 other functionals. Theor. Chem. Account. 2008, 120, 215-241.

(16) Zhao, Y; Truhlar, D. G. Density Functional for Spectroscopy: No Long-Range Self-Interaction Error, Good Performance for Rydberg and Charge-Transfer States, and Better Performance on Average than B3LYP for Ground States. J. Phys. Chem. 2006, 110, 13126-13130.

(17) Valeev, E. F. Libint: A library for the evaluation of molecular integrals of many-body operators over Gaussian functions, http://libint.valeyev.net/

(18) Barone, V.; Cossi, M. Quantum calculation of molecular energies and energy gradients in solution by a conductor solvent model. J. Phys. Chem. A 1998, 102, 1995-2001. 
(19) Glendening, E. D.; Badenhoop, J. K.; Reed, A. E.; Carpenter, J. E., Bohmann, J. A.; Morales, C. M.; Landis, C. R.; Weinhold, F. NBO 6.0. Theoretical Chemistry Institute, University of Wisconsin, Madison, WI, 2013; http://nbo6.chem.wisc.edu.

(20) Hanwell, M. D. ; Curtis, D. E. ; Lonie, D. C. ; Vandermeersch, T. ; Zurek, E.; Hutchison, G. R. Avogadro: an advanced semantic chemical editor, visualization, and analysis platform. Journal of Cheminformatics 2012, 4, 17.

(21) Zhurko, G. A. Chemcraft - graphical program for visualization of quantum chemistry computations. https://chemcraftprog.com.

(22) Christensen, N. J.; Fristrup, P. Kinetic Isotope Effects (KIE) and Density Functional Theory (DFT): A Match Made in Heaven? Synlett 2015, 26, 508-513.

(23) Bondi, A. van der Waals Volumes and Radii J. Phys. Chem. 1964, 68, 441-451.

(24) Li, C.; Danovich, D; Shaik, S. Blended hydrogen atom abstraction and proton-coupled electron transfer mechanisms of closed-shell molecules. Chem. Sci. 2012, 3, 1903-1918. 


\section{SPECTROSCOPIC DATA}

\section{${ }^{1} \mathrm{H}$ NMR of 1-(4-bromophenyl) butan-1-ol (2)}

$\mathrm{CDCl}_{3}, 2{ }^{\circ} \mathrm{C}, 500 \mathrm{MHz}$

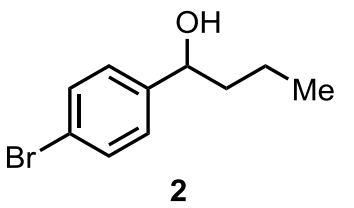

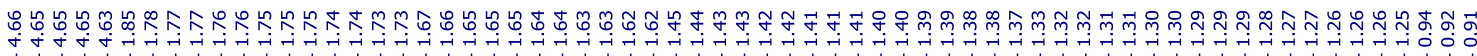

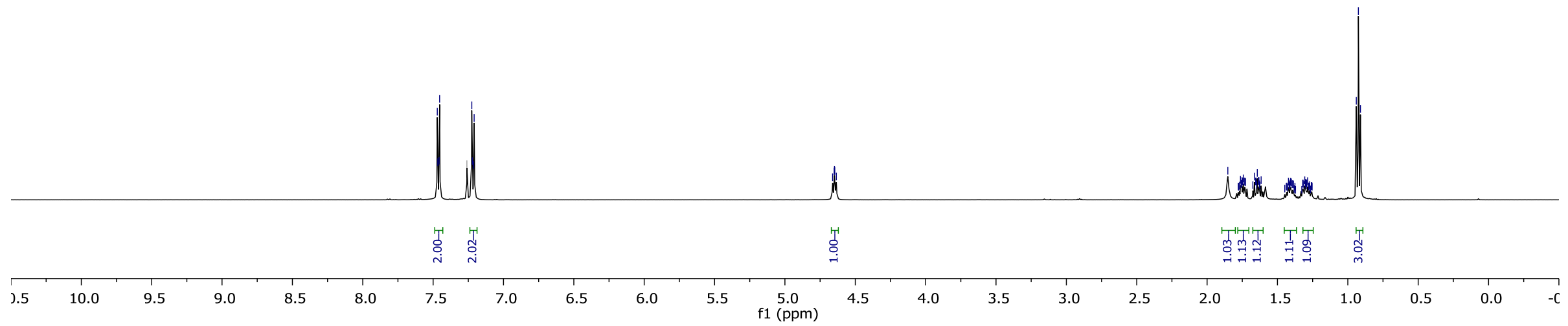


${ }^{13} \mathrm{C}$ NMR of 1-(4-bromophenyl) butan-1-ol (2)

$\mathrm{CDCl}_{3}, 25^{\circ} \mathrm{C}, 126 \mathrm{~Hz}$

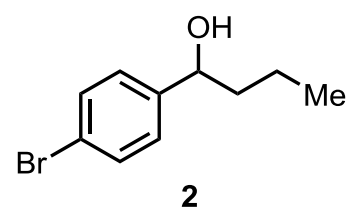

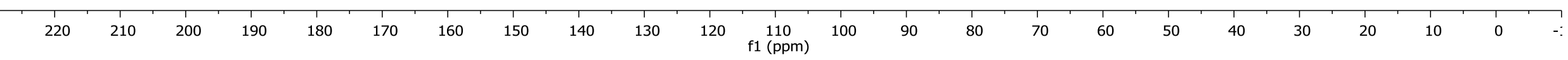


${ }^{1} \mathrm{H}$ NMR of reaction after step 1 of acylated 1-(4-biphenyl) ethanol (3A)

$\mathrm{CDCl}_{3}, 25 \stackrel{\circ}{\mathrm{C}}, 500 \mathrm{MHz}$

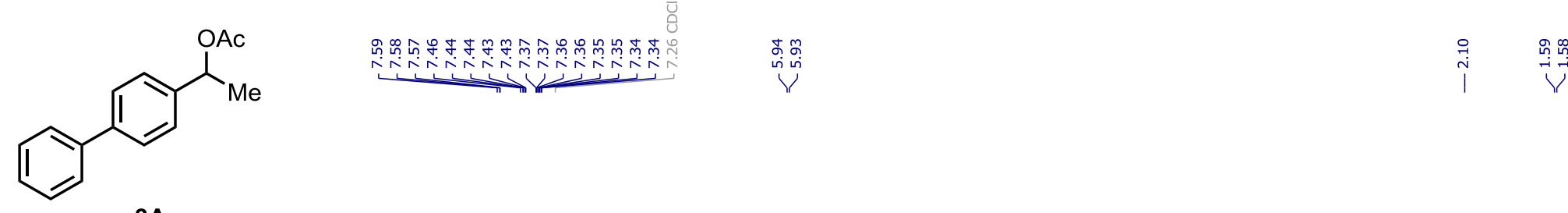

3A

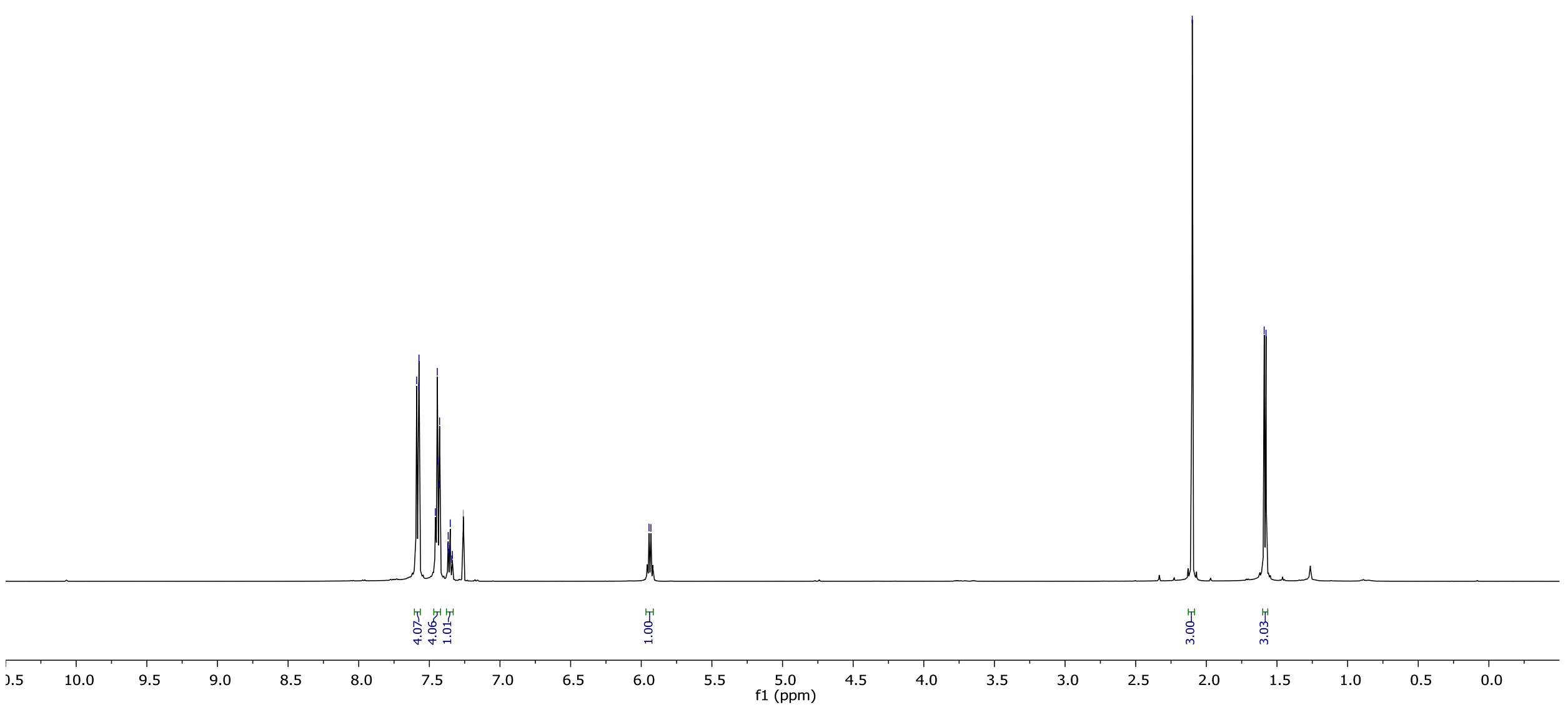




\section{${ }^{1} \mathrm{H}$ NMR of 1-(4-biphenyl) ethanol (3)}

$\left(\mathrm{CD}_{3}\right)_{2} \mathrm{SO}, 25^{\circ} \mathrm{C}, 500 \mathrm{MHz}$
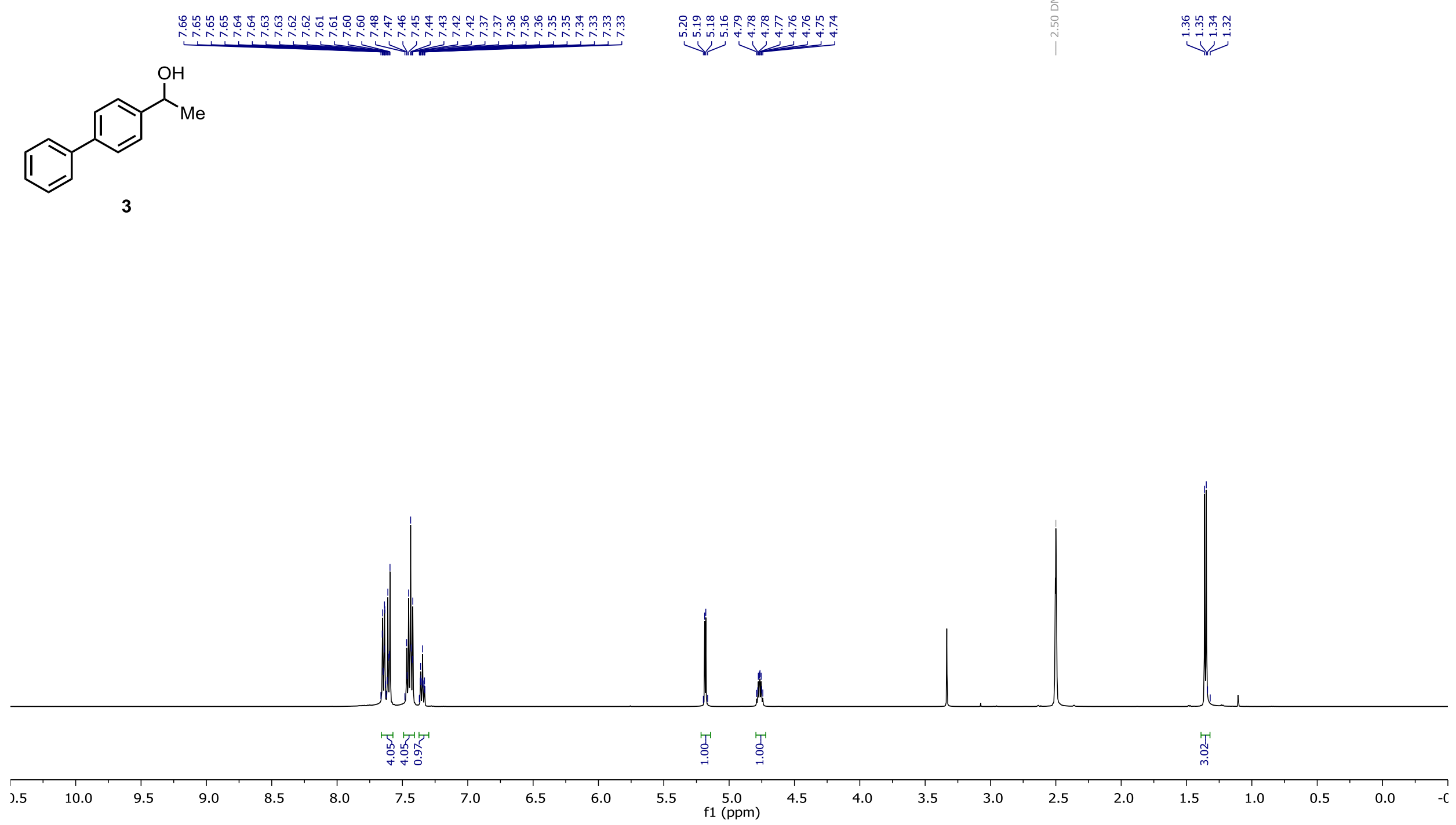
${ }^{13} \mathrm{C}$ NMR of 1-(4-biphenyl) ethanol (3)

$\left(\mathrm{CD}_{3}\right)_{2} \mathrm{SO}, 25 \stackrel{\circ}{\circ} \mathrm{C}, 126 \mathrm{~Hz}$

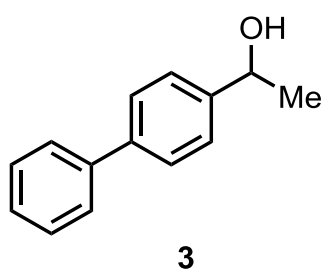

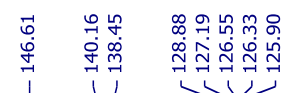

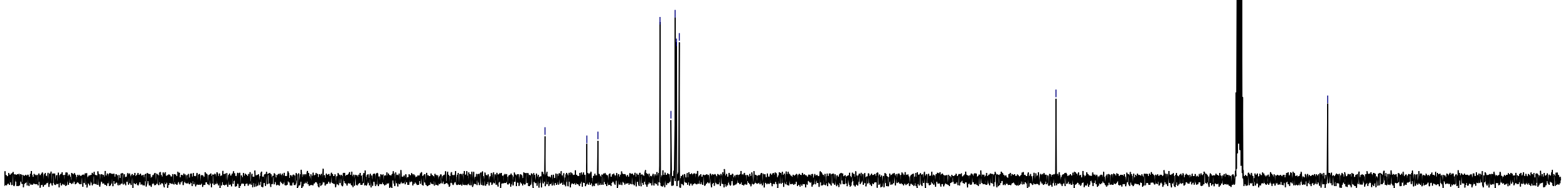

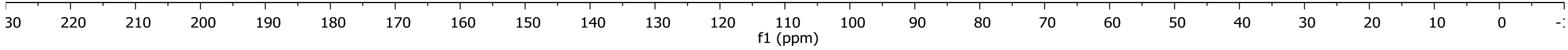


${ }^{1} \mathrm{H}$ NMR of 3-chloro-1-phenylpropan-1-ol (4)

$\mathrm{CDCl}_{3}, 25 \stackrel{\circ}{\mathrm{C}}, 500 \mathrm{MHz}$

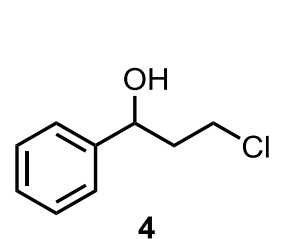

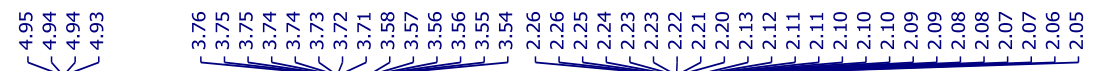

4

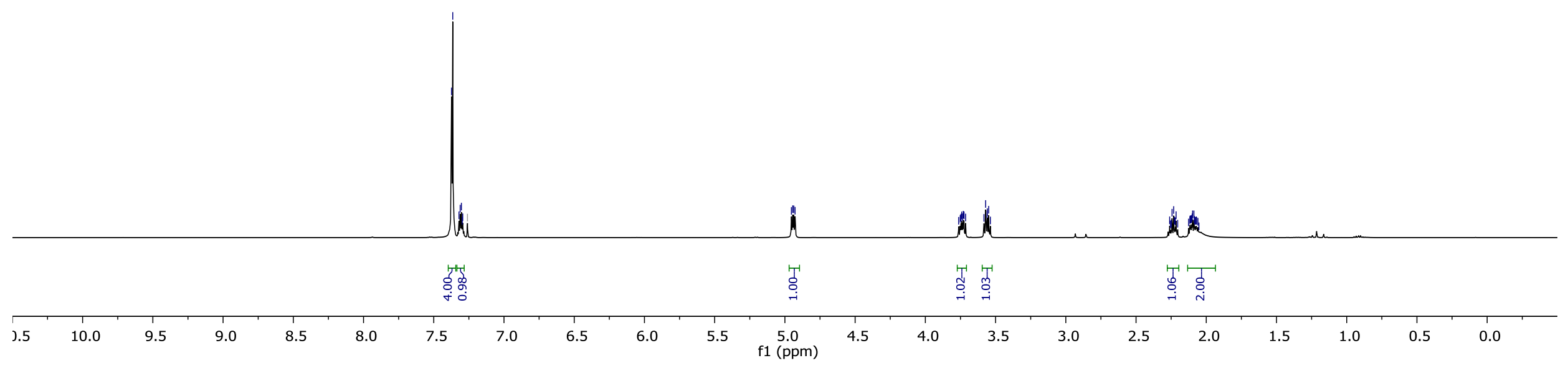


${ }^{13} \mathrm{C}$ NMR of 3-chloro-1-phenylpropan-1-ol (4)

$\mathrm{CDCl}_{3}, 25^{\circ} \mathrm{C}, 126 \mathrm{~Hz}$
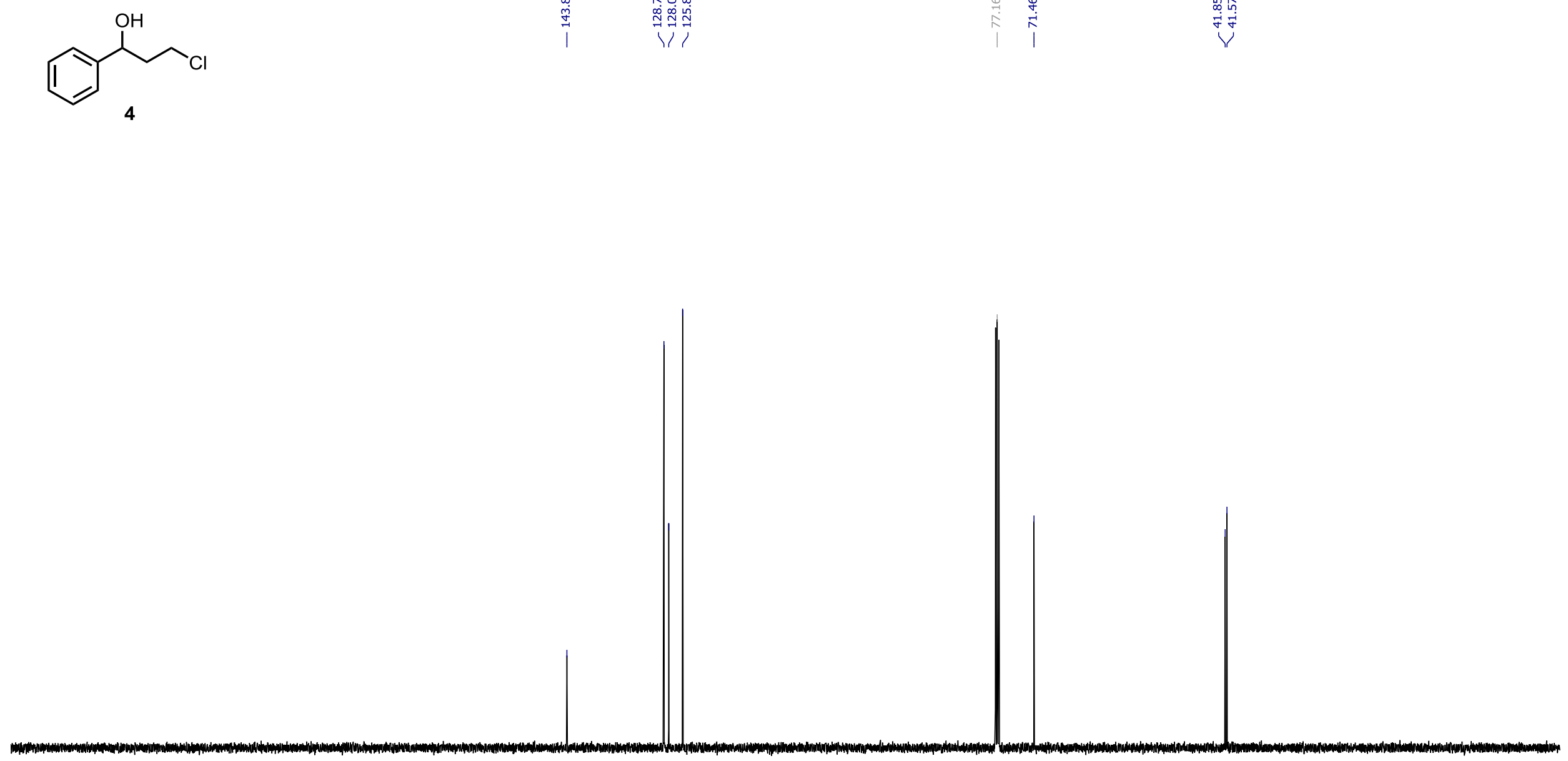

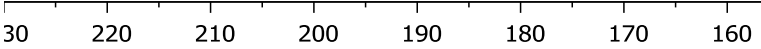

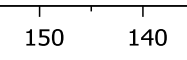

130

$120 \quad \begin{gathered}110 \\ \mathrm{f} 1(\mathrm{ppm})\end{gathered}$

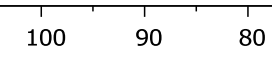

$70 \quad 60$ $50 \quad 40$ 
${ }^{1} \mathrm{H}$ NMR of 3-methyl-1-phenylbutan-1-ol (5)

$\mathrm{CDCl}_{3}, 25 \stackrel{\circ}{\mathrm{C}}, 500 \mathrm{MHz}$
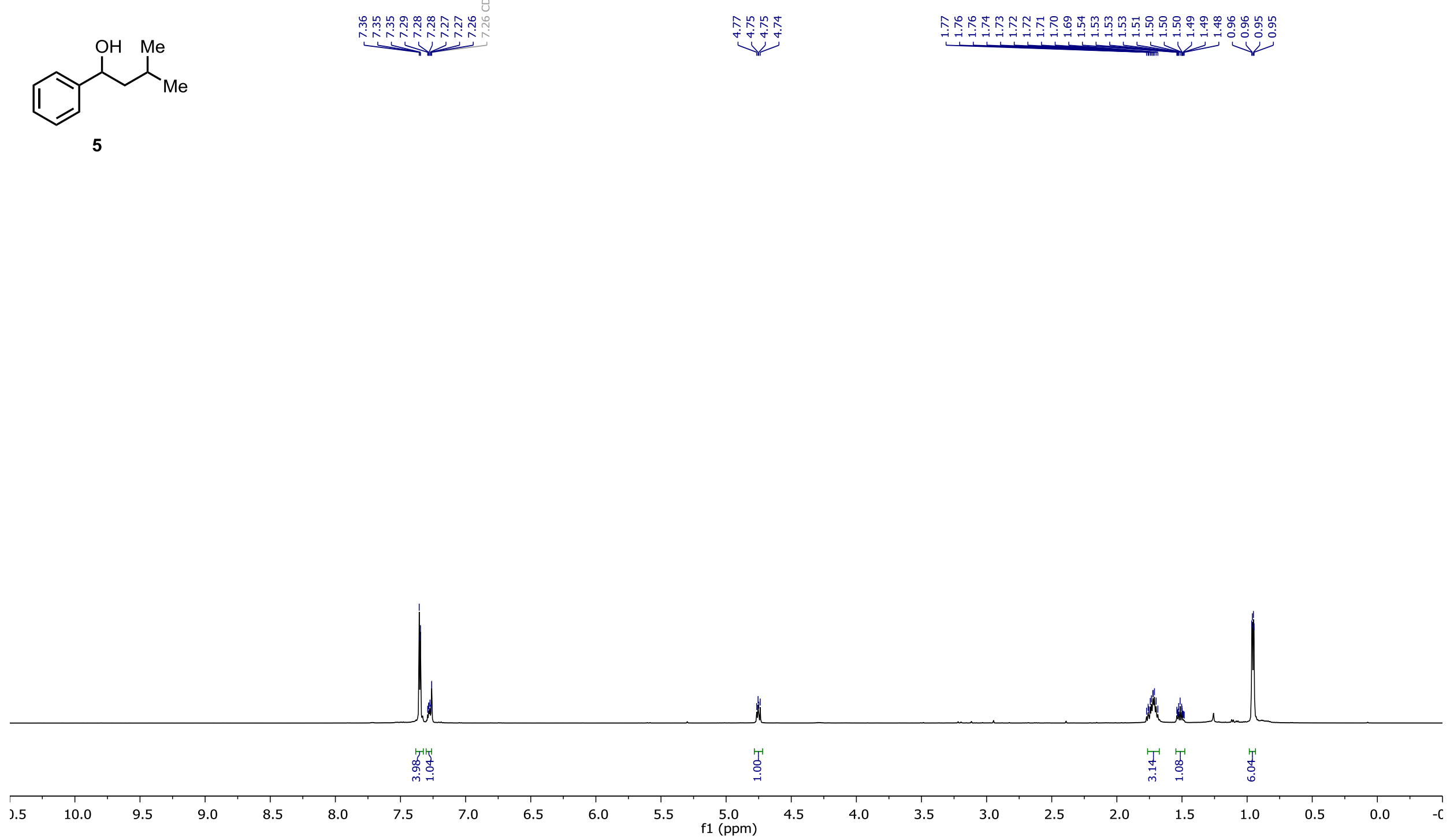
${ }^{13} \mathrm{C}$ NMR of 3-methyl-1-phenylbutan-1-ol (5)

$\mathrm{CDCl}_{3}, 25 \stackrel{\circ}{\circ} \mathrm{C}, 126 \mathrm{~Hz}$

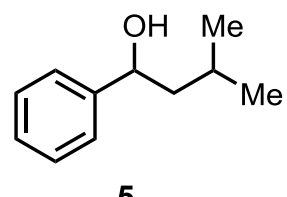


${ }^{1} \mathrm{H}$ NMR of 3-bromo-1-(4-methoxyphenyl) propan-1-ol (6)

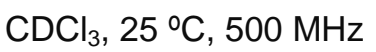
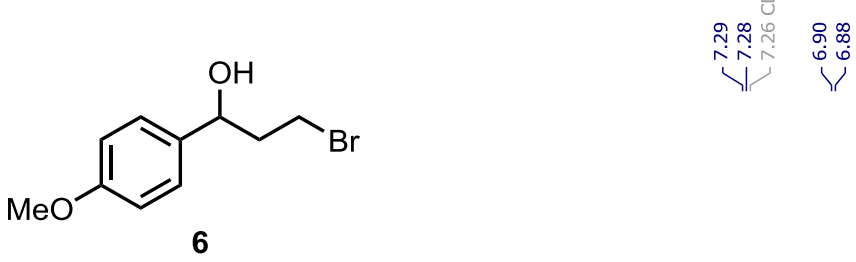

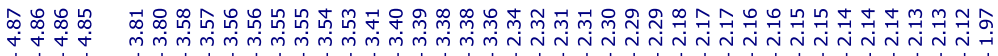

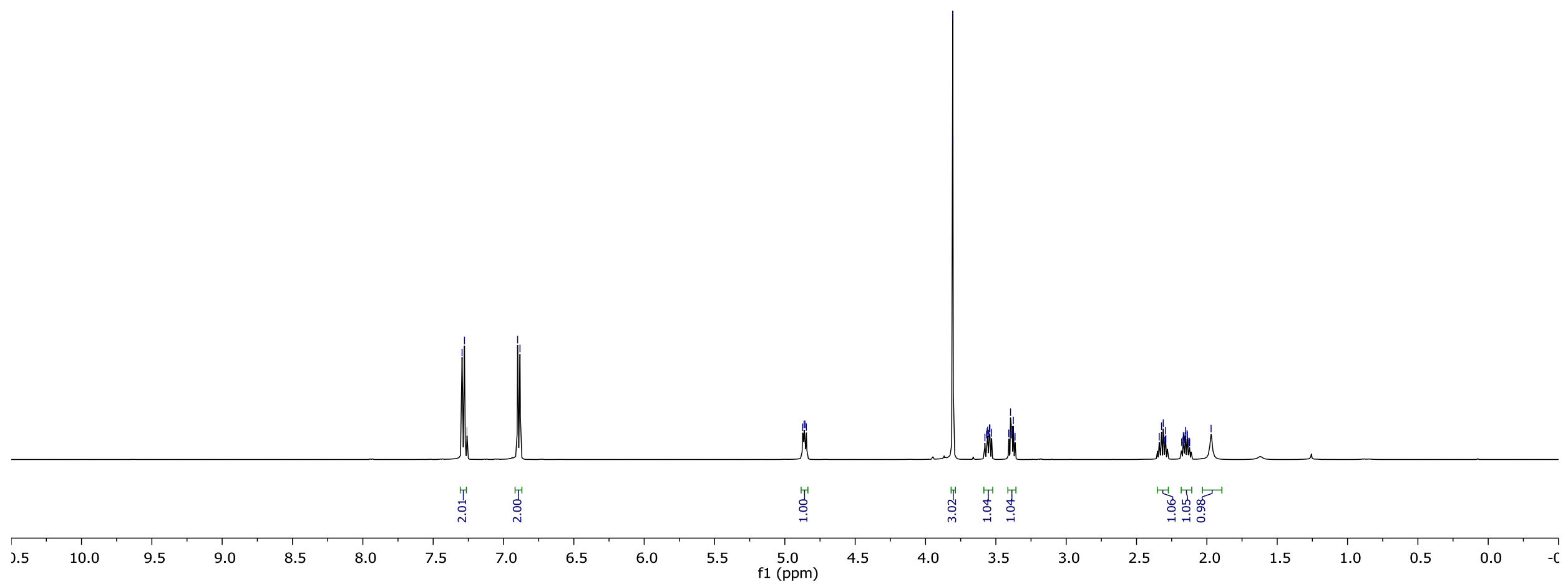


SUPPORTING INFORMATION

S82

${ }^{13} \mathrm{C}$ NMR of 3-bromo-1-(4-methoxyphenyl) propan-1-ol (6)

$\mathrm{CDCl}_{3}, 25^{\circ} \mathrm{C}, 126 \mathrm{~Hz}$<smiles>COc1ccc(C(O)CCBr)cc1</smiles>

6
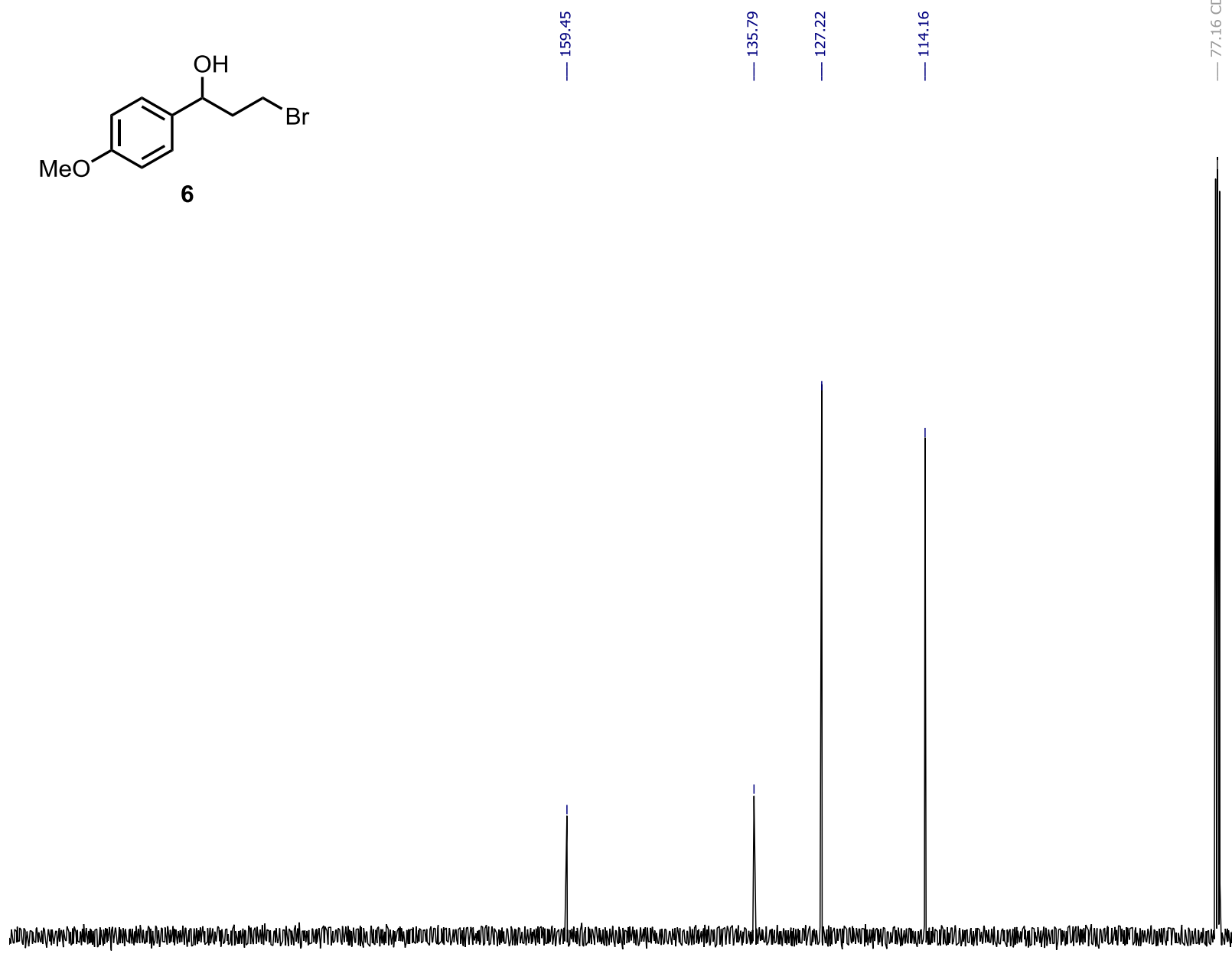

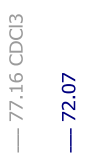

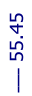

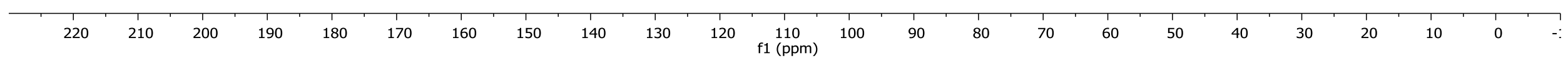


${ }^{1} \mathrm{H}$ NMR of 4-(1-hydroxybutyl) benzonitrile (7)

$\mathrm{CDCl}_{3}, 25 \stackrel{\circ}{\mathrm{C}}, 500 \mathrm{MHz}$

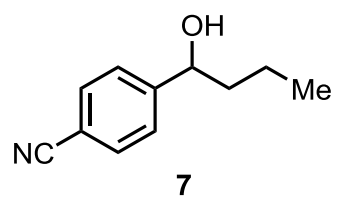

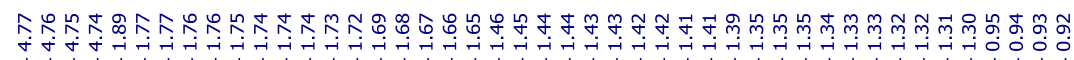
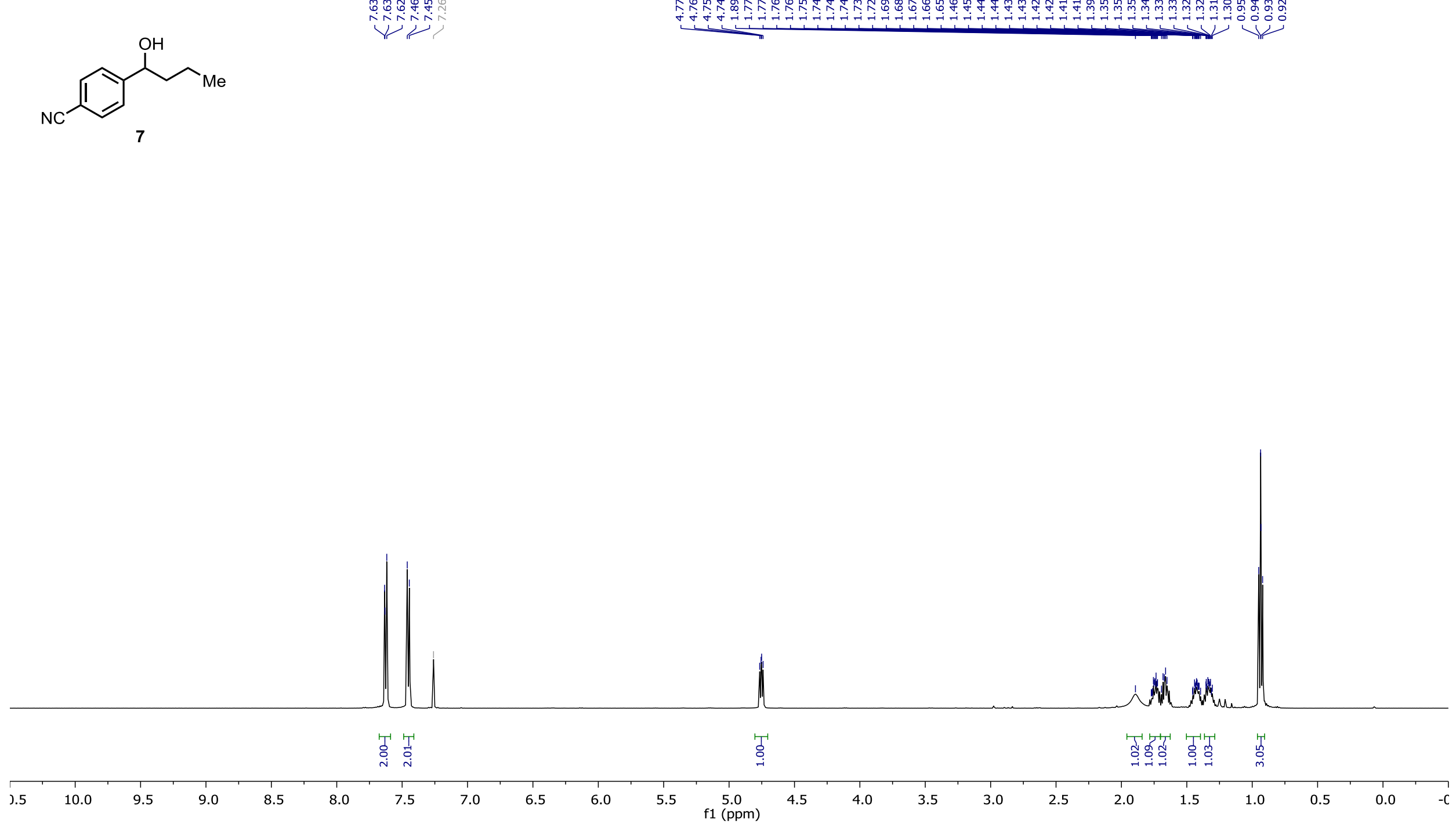
${ }^{13} \mathrm{C}$ NMR of 4-(1-hydroxybutyl) benzonitrile (7)

$\mathrm{CDCl}_{3}, 25^{\circ} \mathrm{C}, 126 \mathrm{~Hz}$

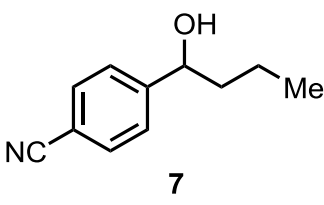

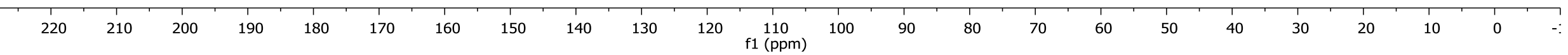


${ }^{1} \mathrm{H}$ NMR of 1-phenylbut-3-en-1-ol (8)

$\mathrm{CDCl}_{3}, 25 \stackrel{\circ}{\mathrm{C}}, 500 \mathrm{MHz}$
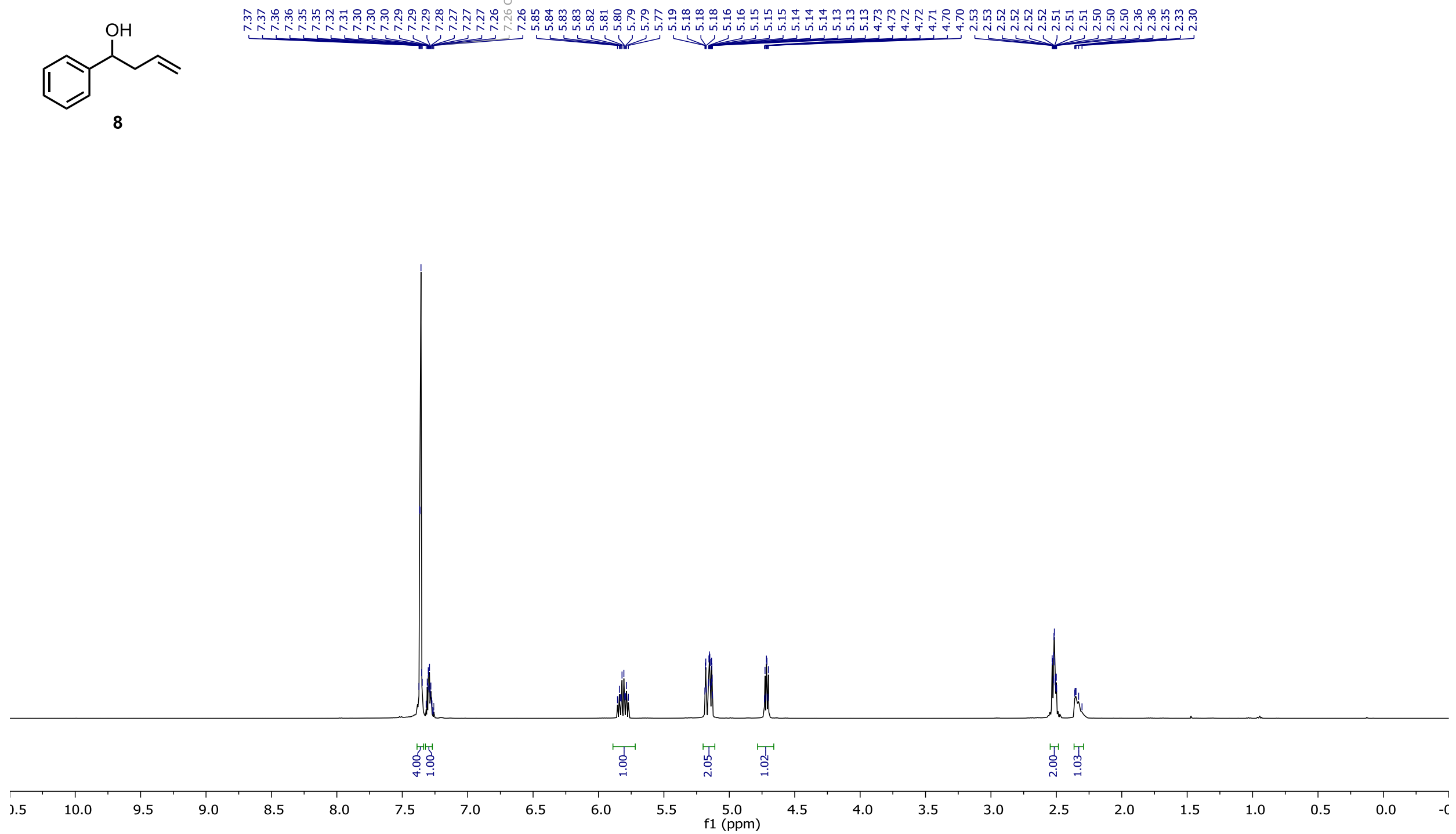
${ }^{13} \mathrm{C}$ NMR of 1-phenylbut-3-en-1-ol (8)

$\mathrm{CDCl}_{3}, 25 \stackrel{\circ}{\circ} \mathrm{C}, 126 \mathrm{~Hz}$

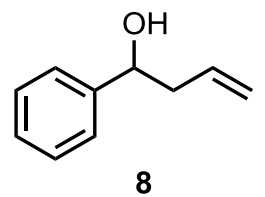

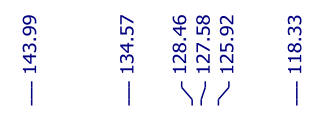
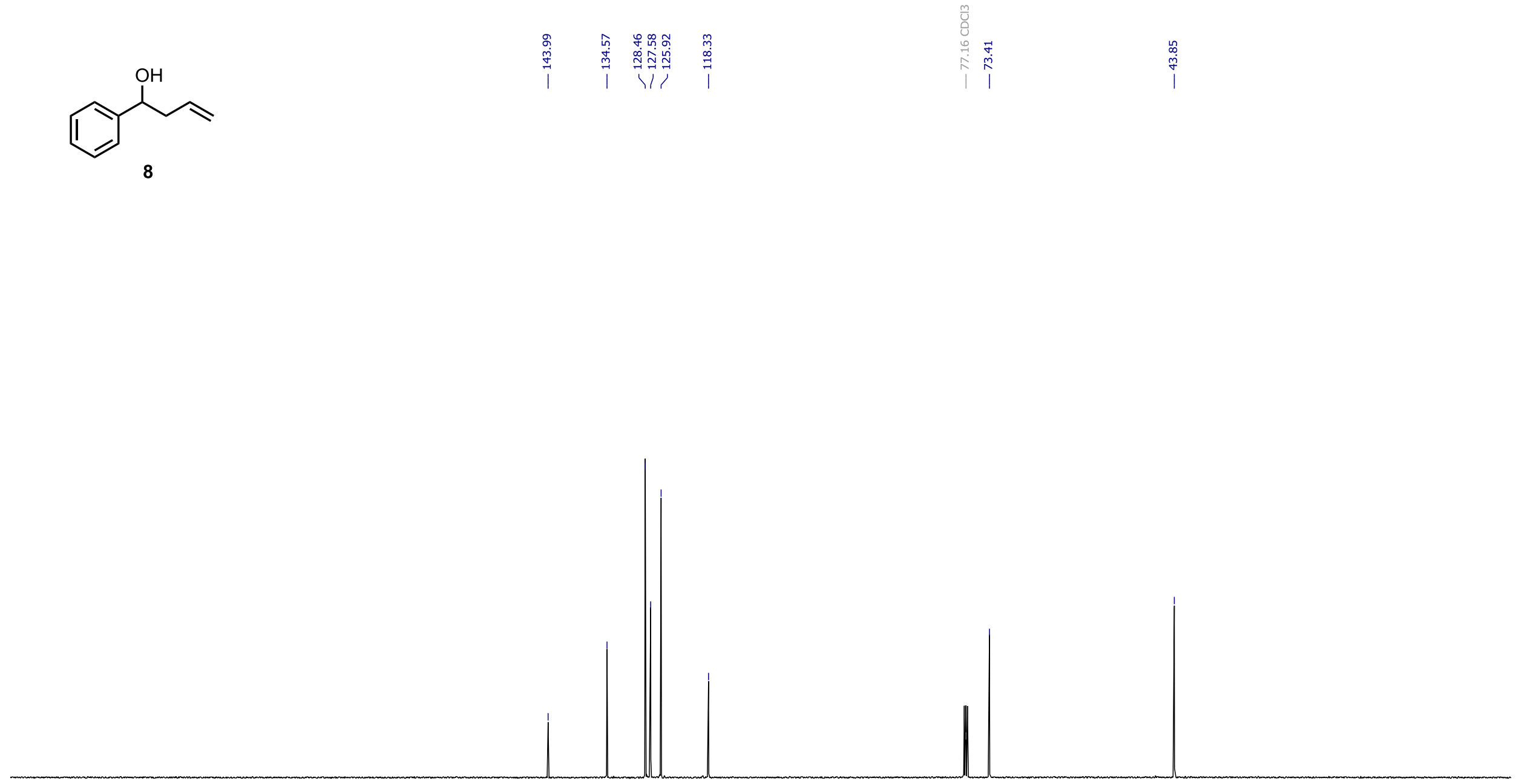

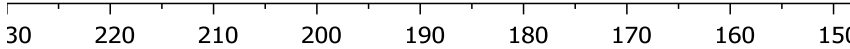
140 130 
${ }^{1} \mathrm{H}$ NMR of 1-phenylpent-4-yn-1-ol (9)

$\mathrm{CDCl}_{3}, 25 \stackrel{\circ}{\mathrm{C}}, 500 \mathrm{MHz}$

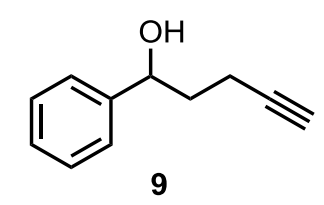

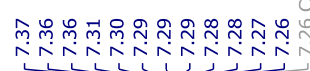

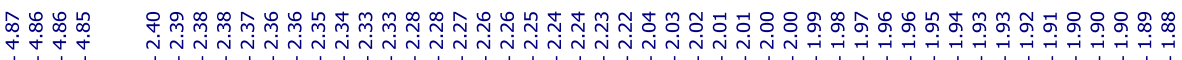

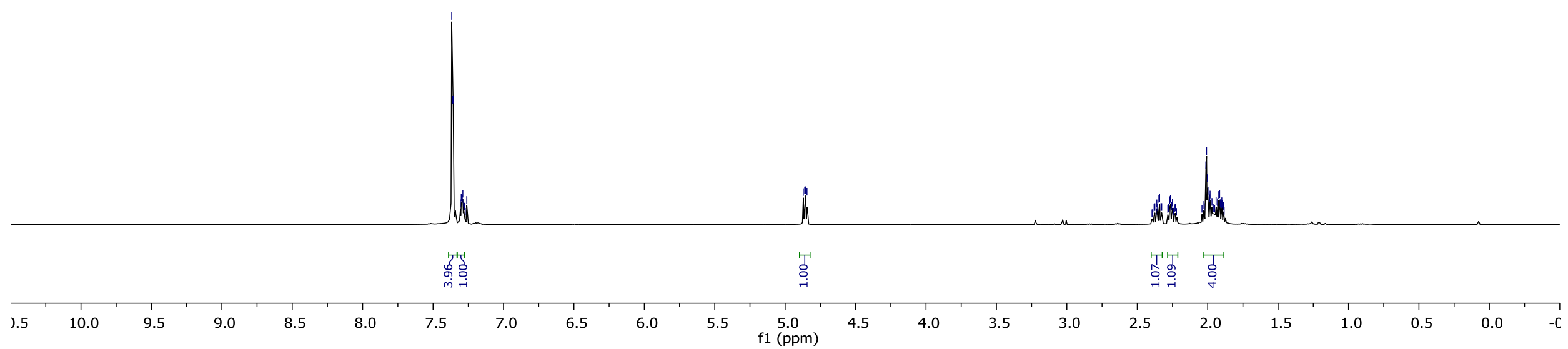


SUPPORTING INFORMATION

S88

${ }^{13} \mathrm{C}$ NMR of 1-phenylpent-4-yn-1-ol (9)

$\mathrm{CDCl}_{3}, 25^{\circ} \mathrm{C}, 126 \mathrm{~Hz}$
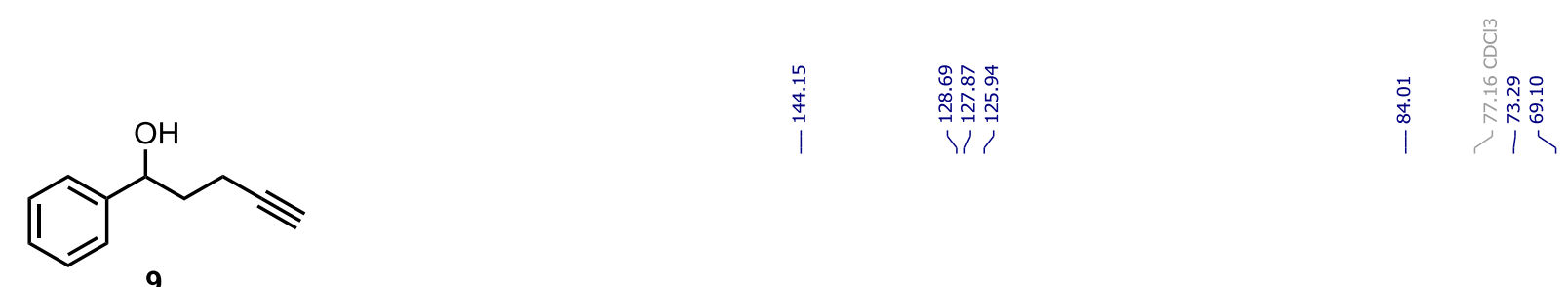

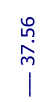

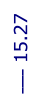

9
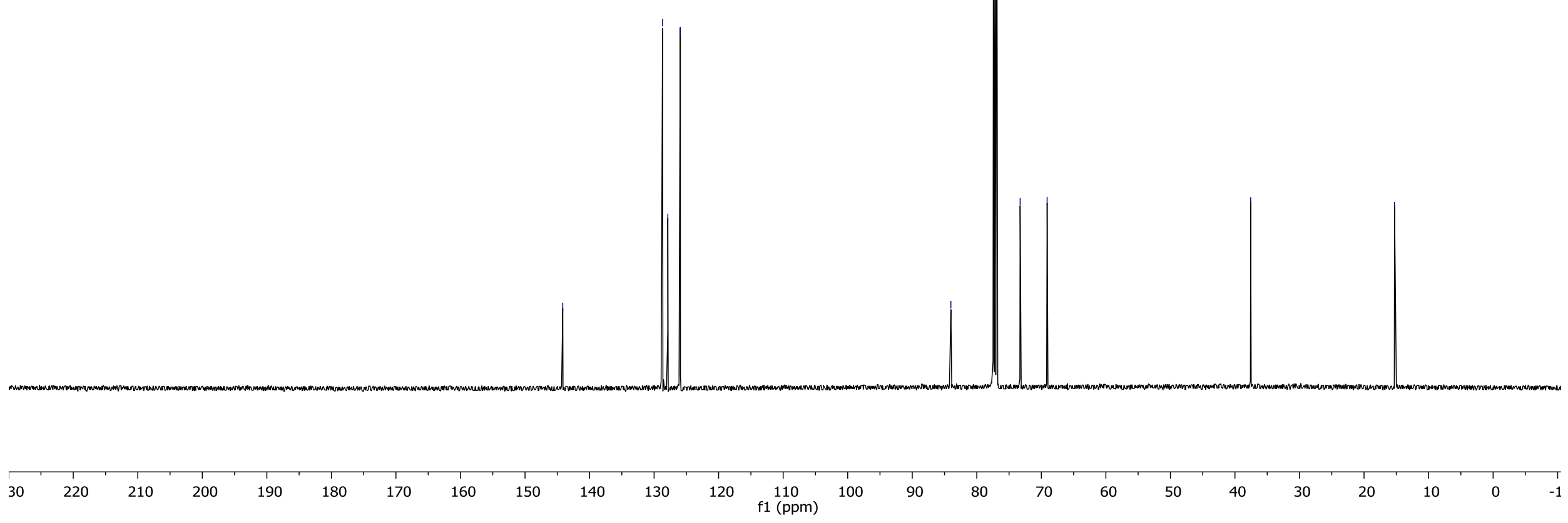
${ }^{1} \mathrm{H}$ NMR of (4-isocyanophenyl) methanol (10)

$\mathrm{CDCl}_{3}, 25 \stackrel{\circ}{\mathrm{C}}, 500 \mathrm{MHz}$
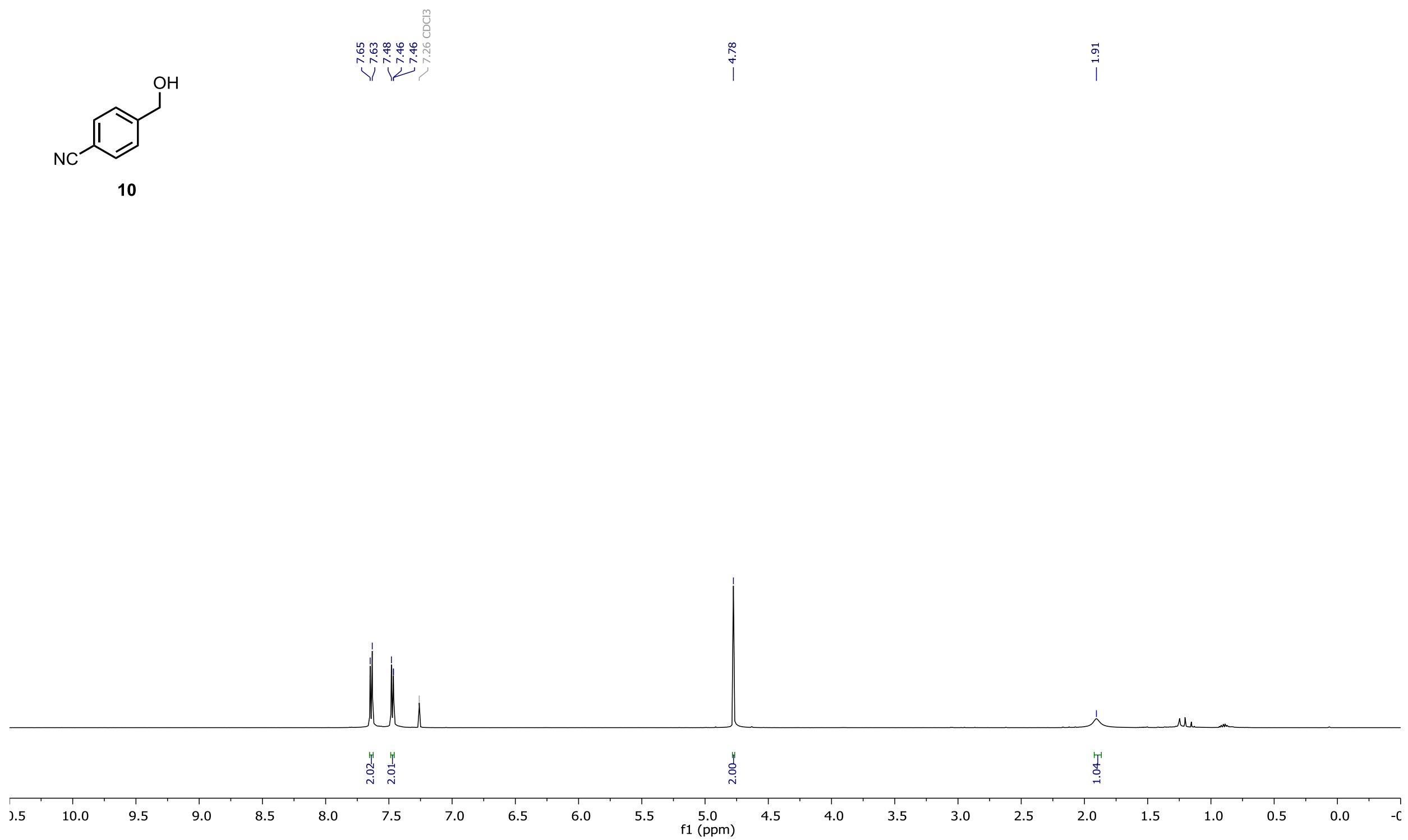
${ }^{13} \mathrm{C}$ NMR of (4-isocyanophenyl) methanol (10)

$\mathrm{CDCl}_{3}, 25^{\circ} \mathrm{C}, 126 \mathrm{~Hz}$
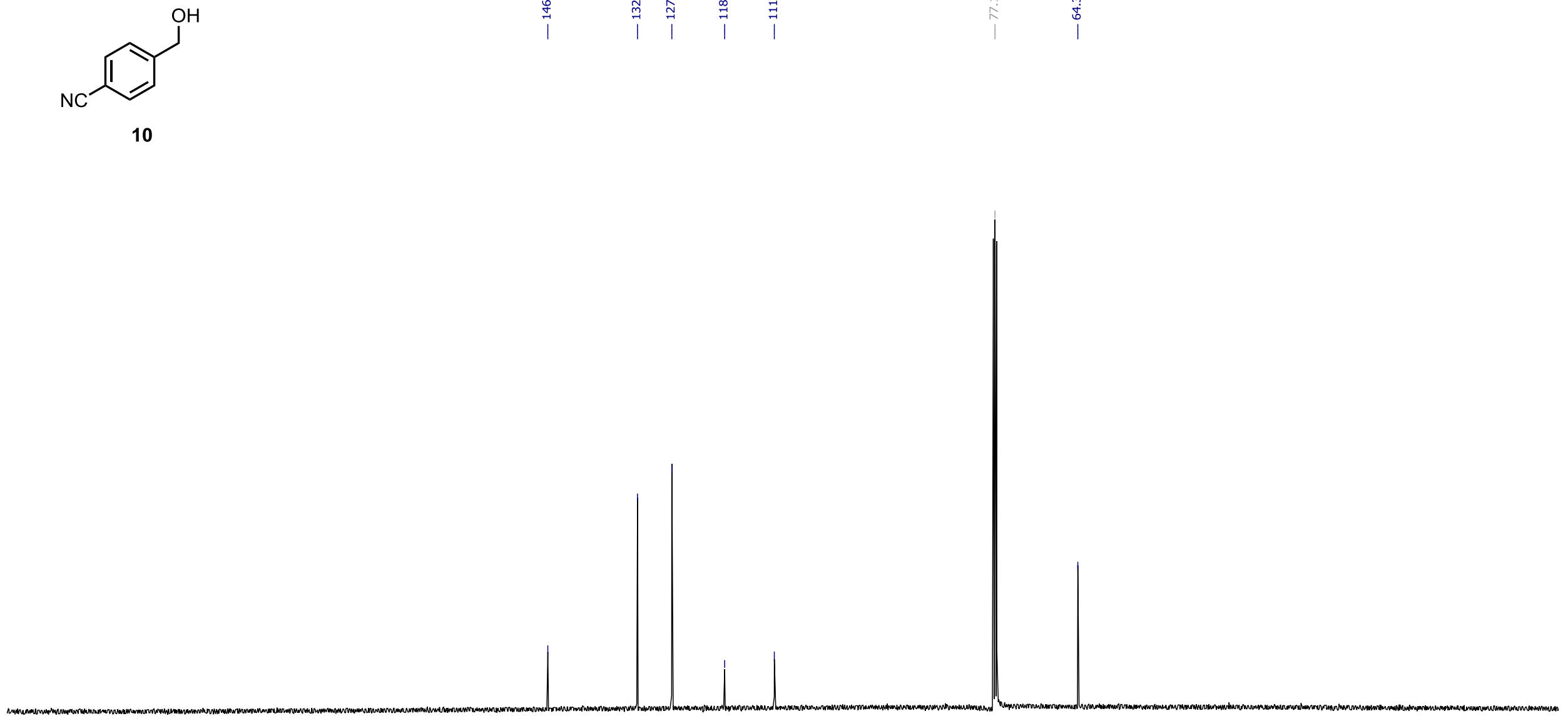
${ }^{1} \mathrm{H}$ NMR of methyl 4-(hydroxymethyl) benzoate (11)

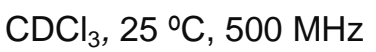
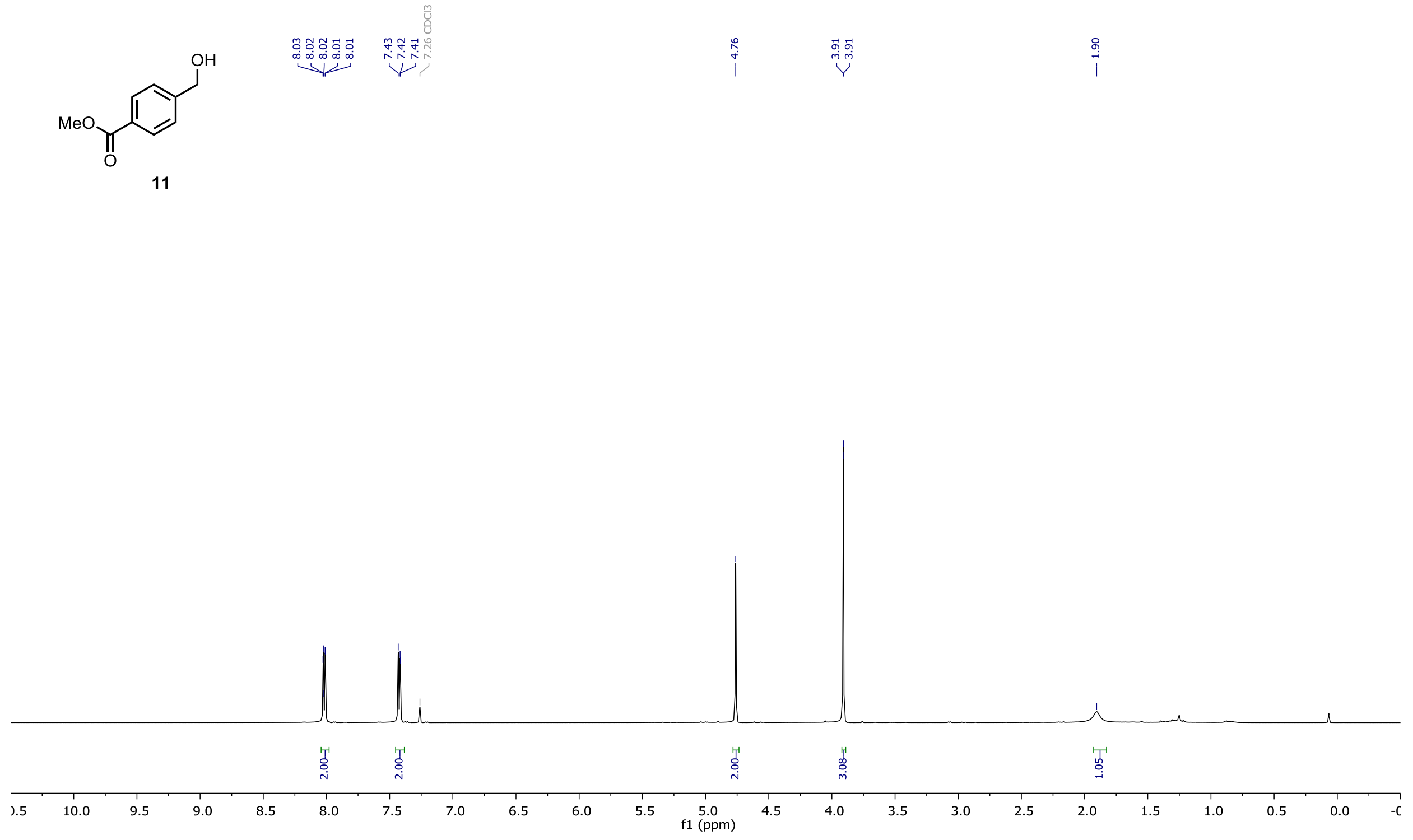
SUPPORTING INFORMATION

S92

${ }^{13} \mathrm{C}$ NMR of methyl 4-(hydroxymethyl) benzoate (11)

$\mathrm{CDCl}_{3}, 25^{\circ} \mathrm{C}, 126 \mathrm{~Hz}$
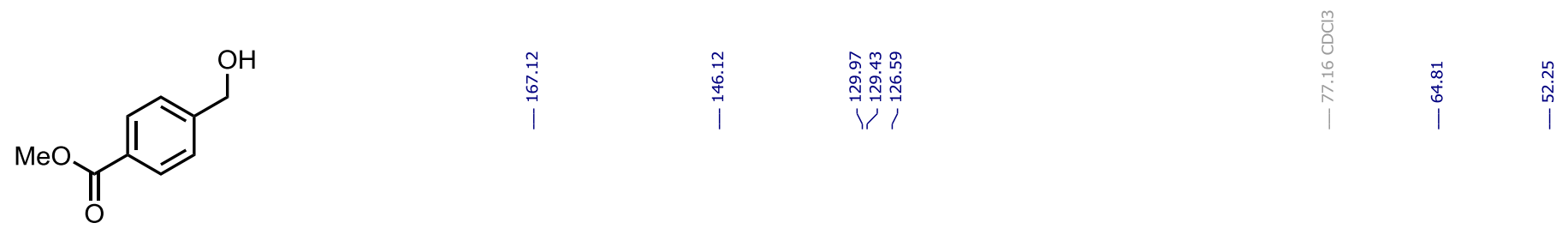

11
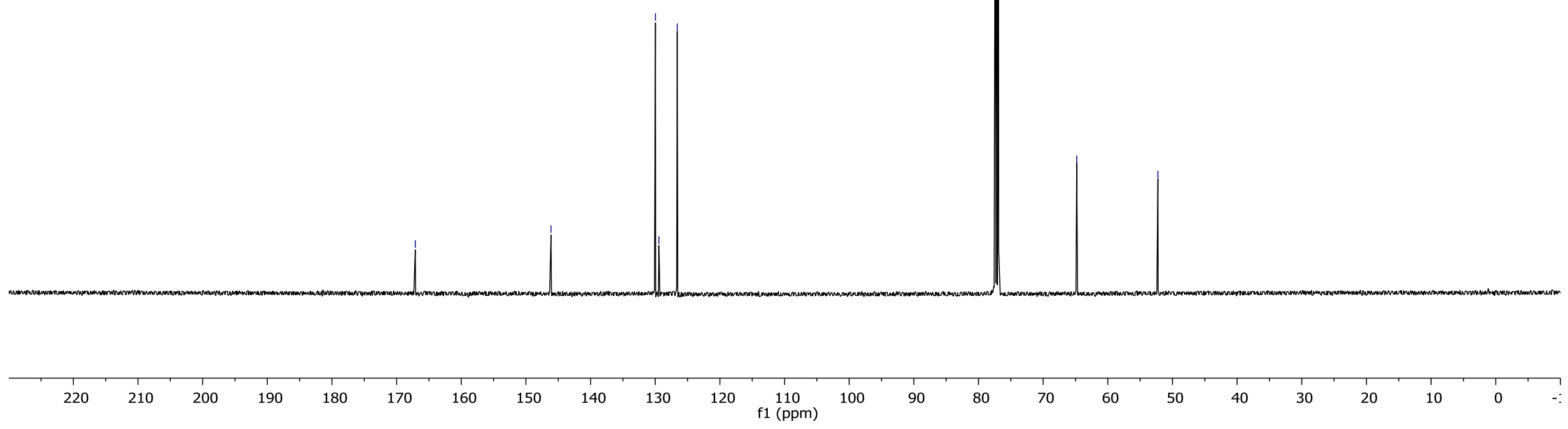
${ }^{1}$ H NMR of ethyl-3-(5-bromo-2-fluorophenyl)-3-hydroxypropanoate (12)

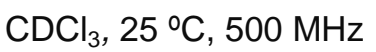
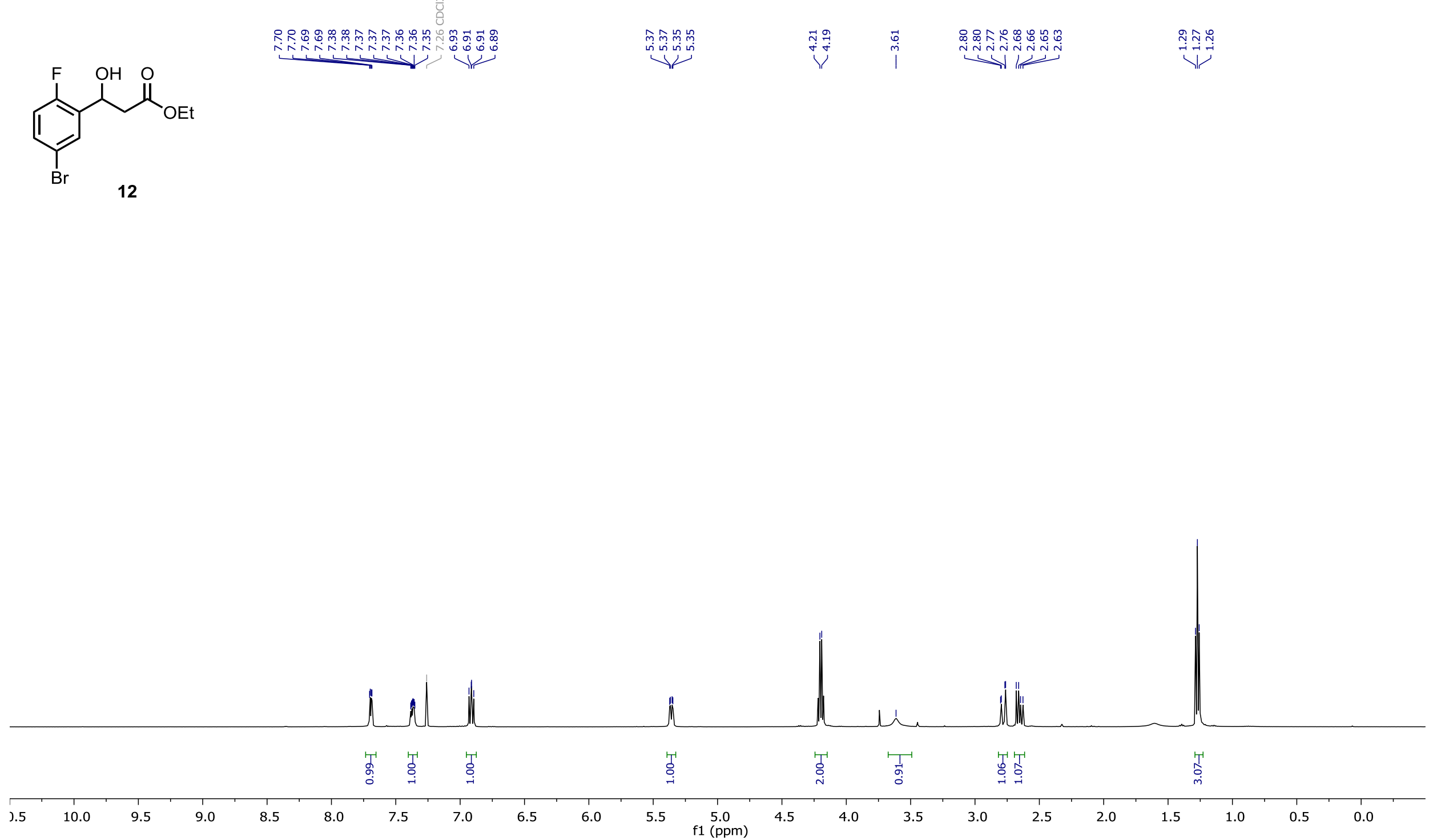
${ }^{13} \mathrm{C}$ NMR of ethyl-3-(5-bromo-2-fluorophenyl)-3-hydroxypropanoate (12)

$\mathrm{CDCl}_{3}, 25 \stackrel{\circ}{\mathrm{C}}, 126 \mathrm{~Hz}$

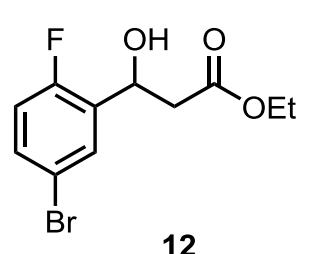

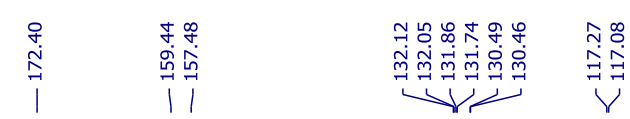

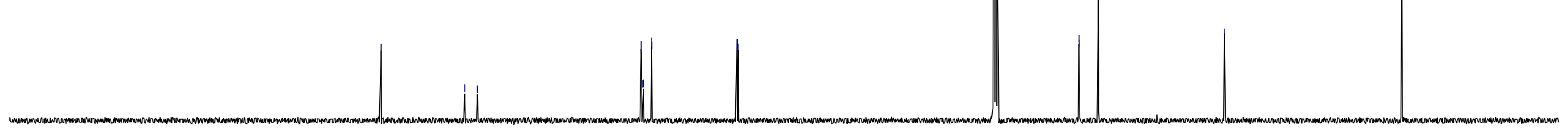


${ }^{19}$ F NMR of ethyl-3-(5-bromo-2-fluorophenyl)-3-hydroxypropanoate (12)

$\mathrm{CDCl}_{3}, 25 \stackrel{\circ}{\mathrm{C}}, 471 \mathrm{MHz}$
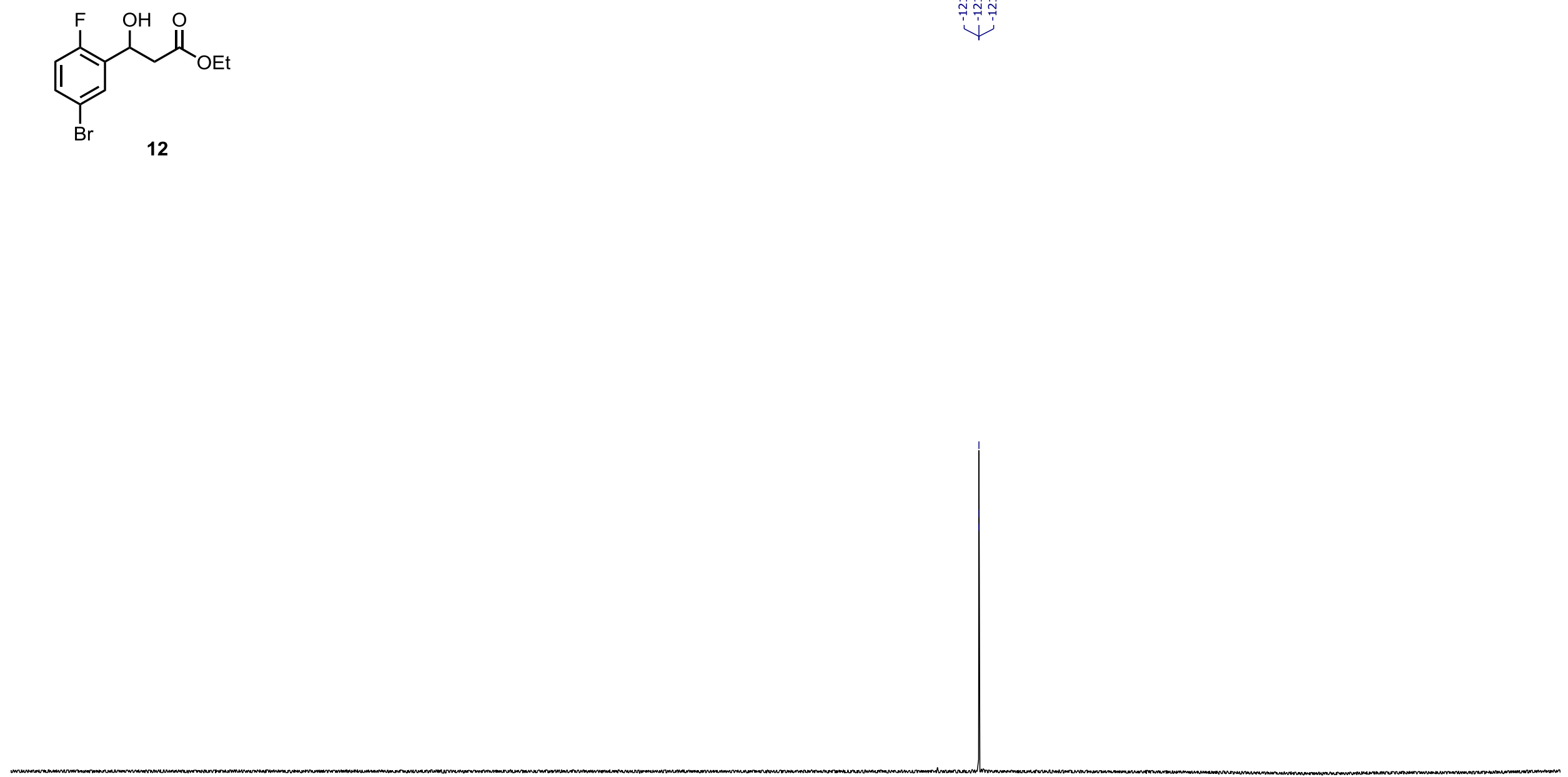
${ }^{1} \mathrm{H}$ NMR of mthyl-3-hydroxy-3-(3-trifluoromethyl)phenyl) propanoate.(13)

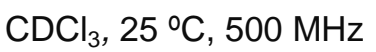

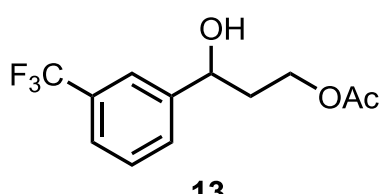

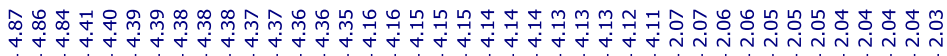

13

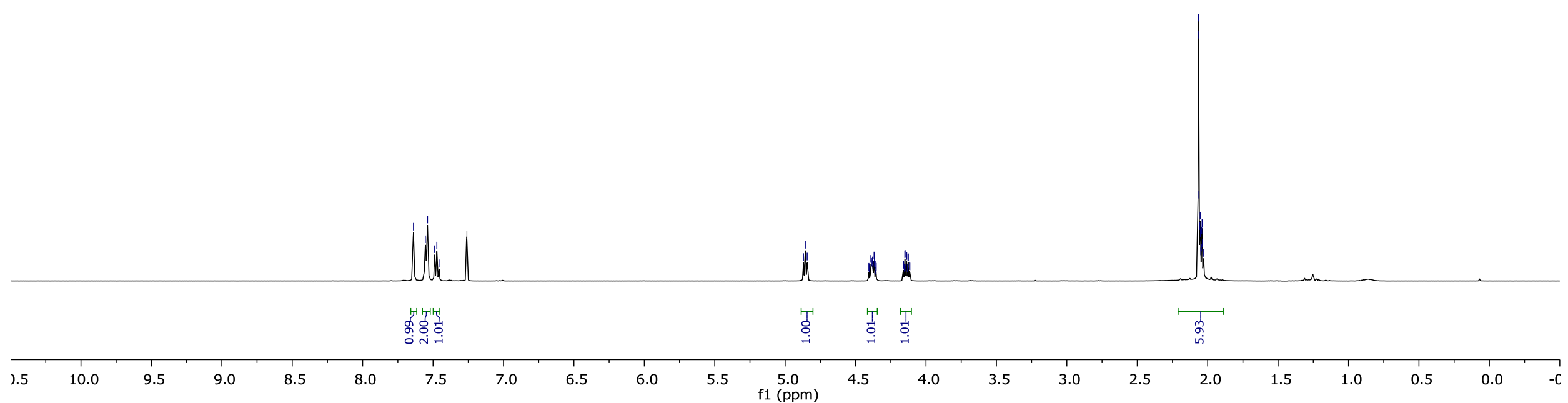


${ }^{13} \mathrm{C}$ NMR of methyl-3-hydroxy-3-(3-trifluoromethyl)phenyl) propanoate(13)

$\mathrm{CDCl}_{3}, 25 \stackrel{\circ}{\circ} \mathrm{C}, 126 \mathrm{~Hz}$

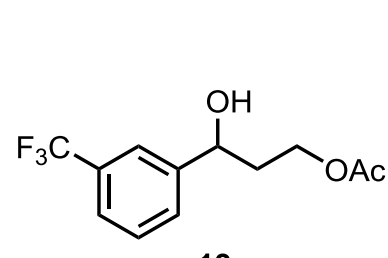

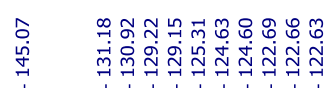

13

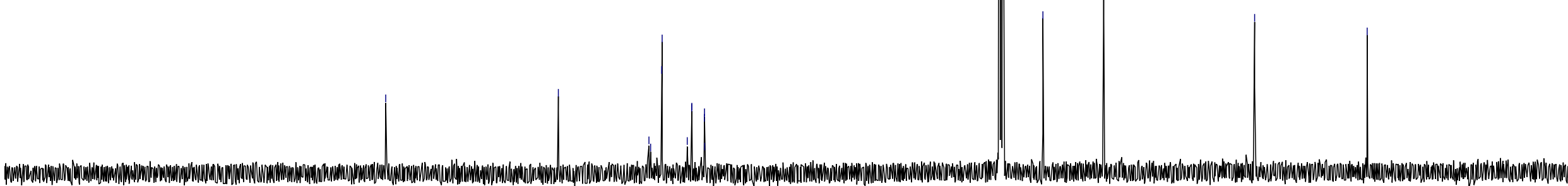

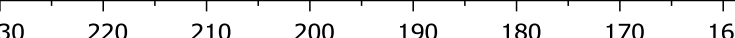

140

130

$120 \quad 110$

$100 \quad 90$

80

$70 \quad 60$

50

40

30

20 
${ }^{19} \mathrm{~F}$ NMR of methyl-3-hydroxy-3-(3-trifluoromethyl)phenyl) propanoate (13)

$\mathrm{CDCl}_{3}, 25 \stackrel{\circ}{\mathrm{C}}, 471 \mathrm{MHz}$

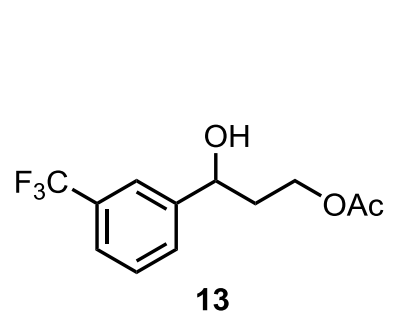

\section{3}

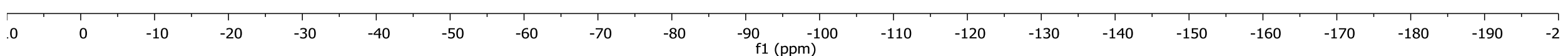


${ }^{1} \mathrm{H}$ NMR of hydroxy-phenylalanine derivative 14

$\mathrm{CDCl}_{3}, 25 \stackrel{\circ}{\mathrm{C}}, 500 \mathrm{MHz}$

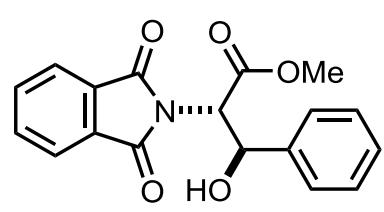

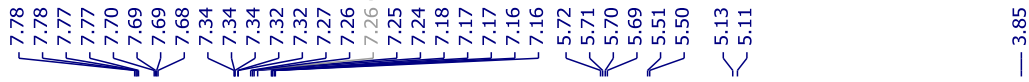

14

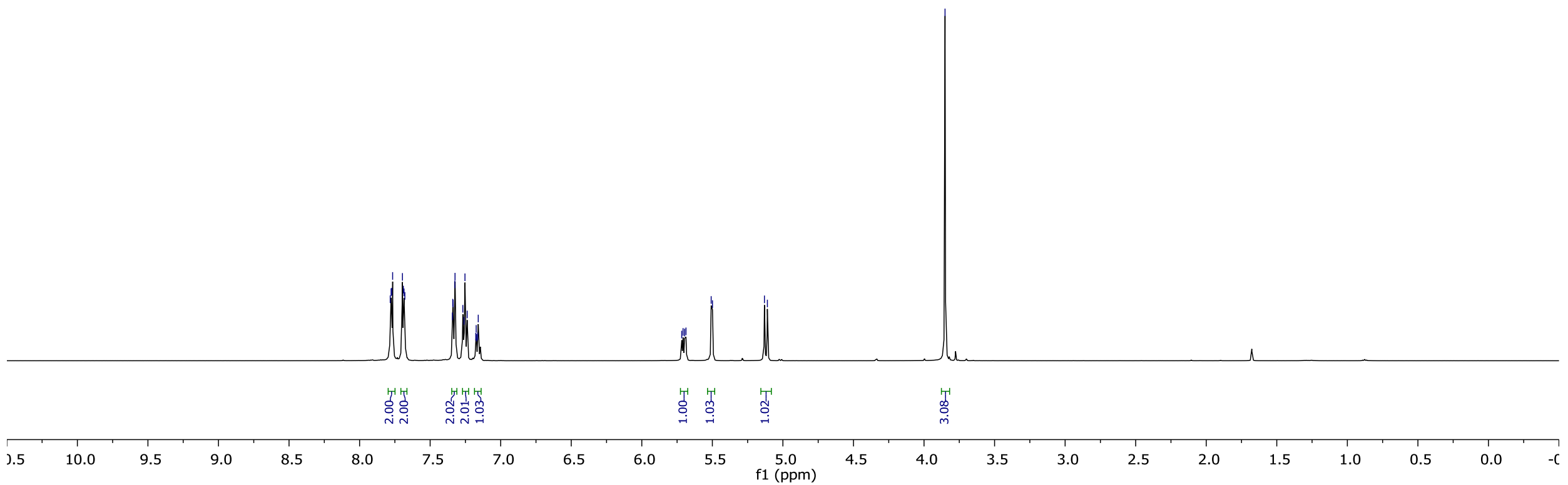


${ }^{13} \mathrm{C}$ NMR of hydroxy-phenylalanine derivative 14

$\mathrm{CDCl}_{3}, 25^{\circ} \mathrm{C}, 126 \mathrm{~Hz}$
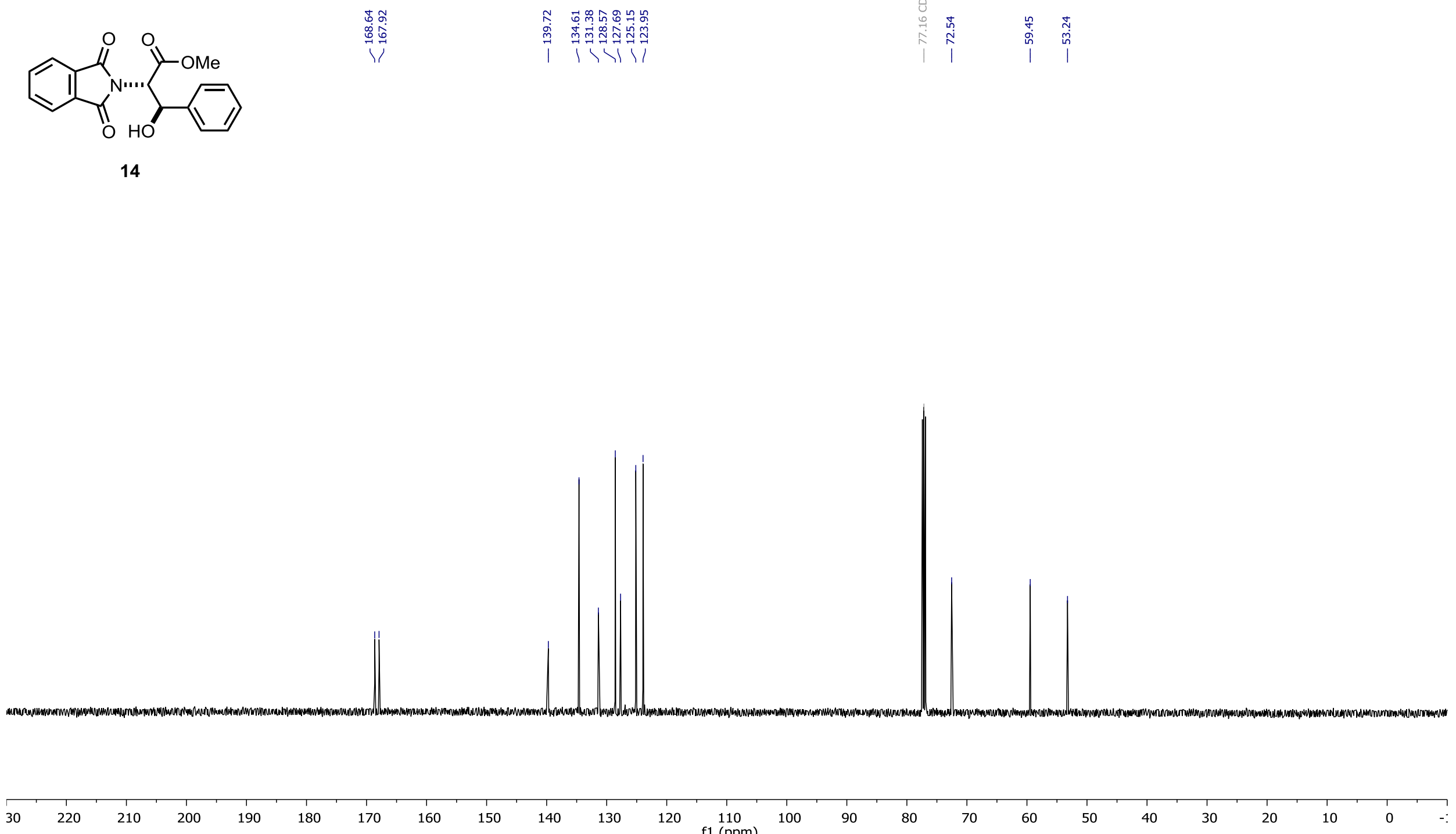

120 


\section{${ }^{1} \mathrm{H}$ NMR of hydroxylated-dextromethorphan derivative 15}

$\mathrm{CDCl}_{3}, 25 \stackrel{\circ}{\mathrm{C}}, 500 \mathrm{MHz}$
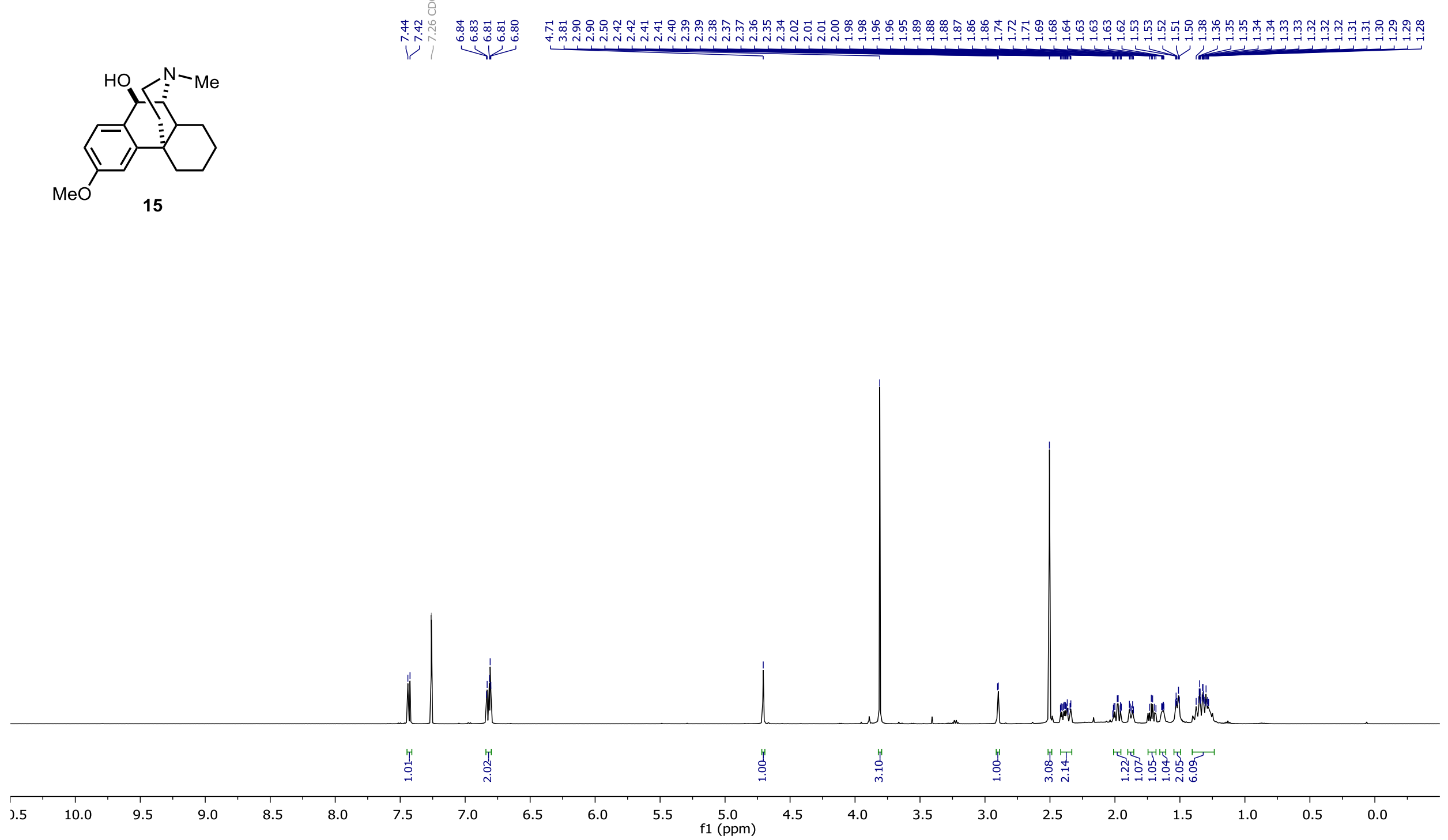
${ }^{13} \mathrm{C}$ NMR of hydroxylated-dextromethorphan derivative 15

$\mathrm{CDCl}_{3}, 25 \stackrel{\circ}{\circ} \mathrm{C}, 126 \mathrm{~Hz}$

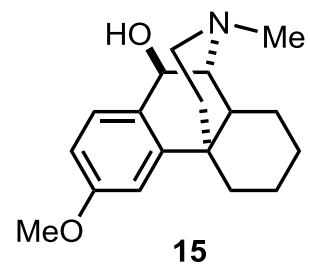

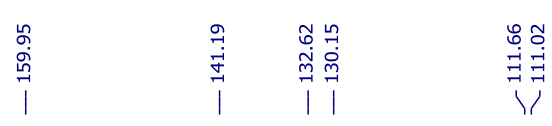
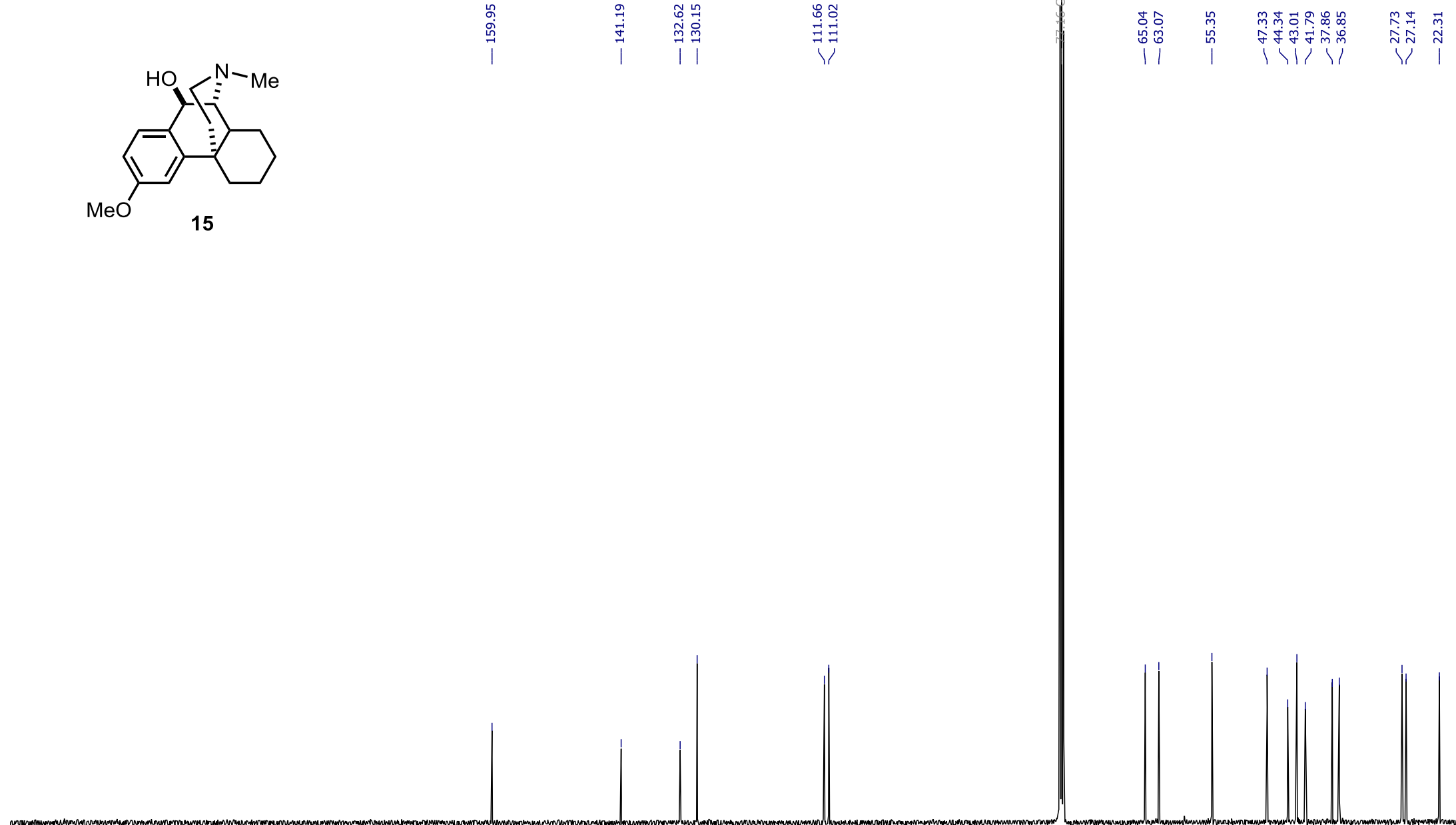

$30 \quad 220 \quad 210 \quad 200 \quad 190$

180

$170 \quad 160$

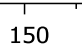

$130 \quad 130$

$120 \quad 110$

$100 \quad 90$

80

$70 \quad 60$

$50 \quad 40$

$30 \quad 20$ 


\section{${ }^{1} \mathrm{H}$ NMR of dextromethorphan ketone 15A}

$\mathrm{CDCl}_{3}, 25 \stackrel{\circ}{\circ} \mathrm{C}, 500 \mathrm{MHz}$

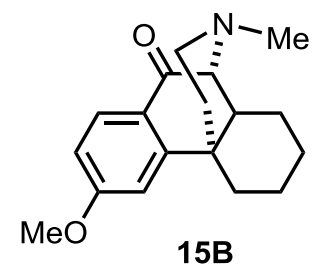

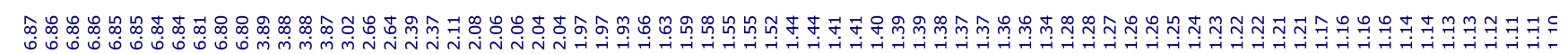

$15 \mathrm{~B}$

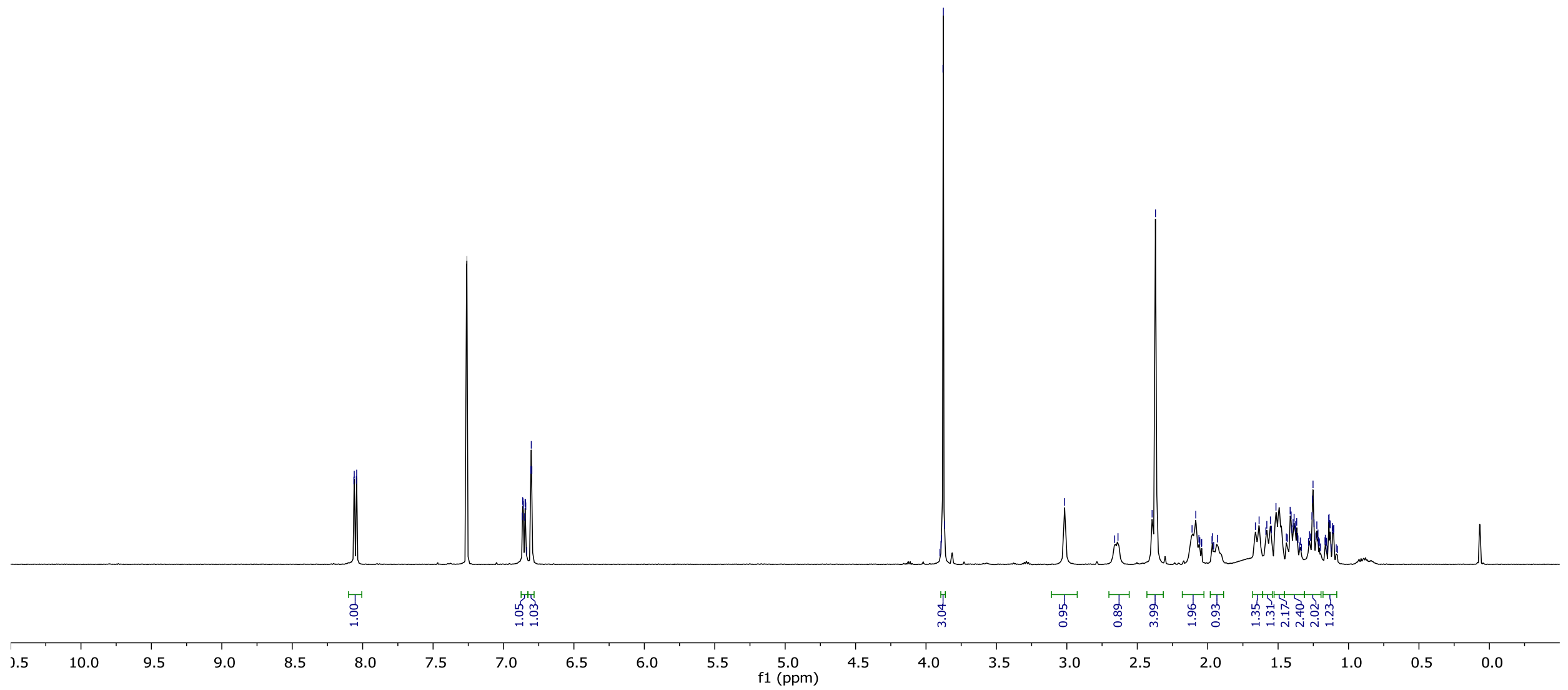


H-H COSY spectrum of hydroxylated-dextromethorphan derivative 15

$\mathrm{CDCl}_{3}, 25 \stackrel{\circ}{\mathrm{C}}$

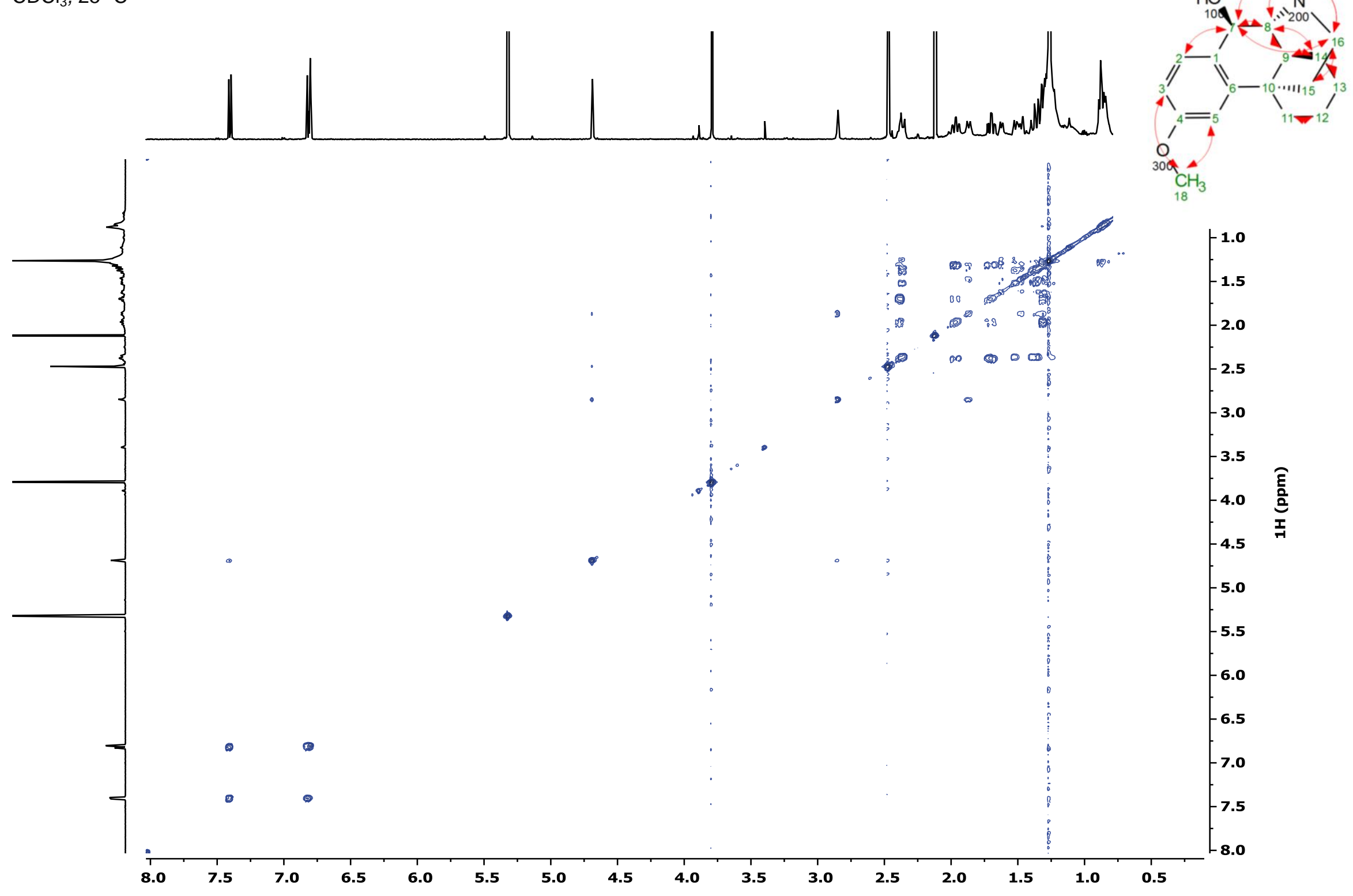


${ }^{1} \mathrm{H}-{ }^{13} \mathrm{C}$ HMBC spectrum of hydroxylated-dextromethorphan derivative 15

$\mathrm{CDCl}_{3}, 25 \stackrel{\circ}{\circ} \mathrm{C}$

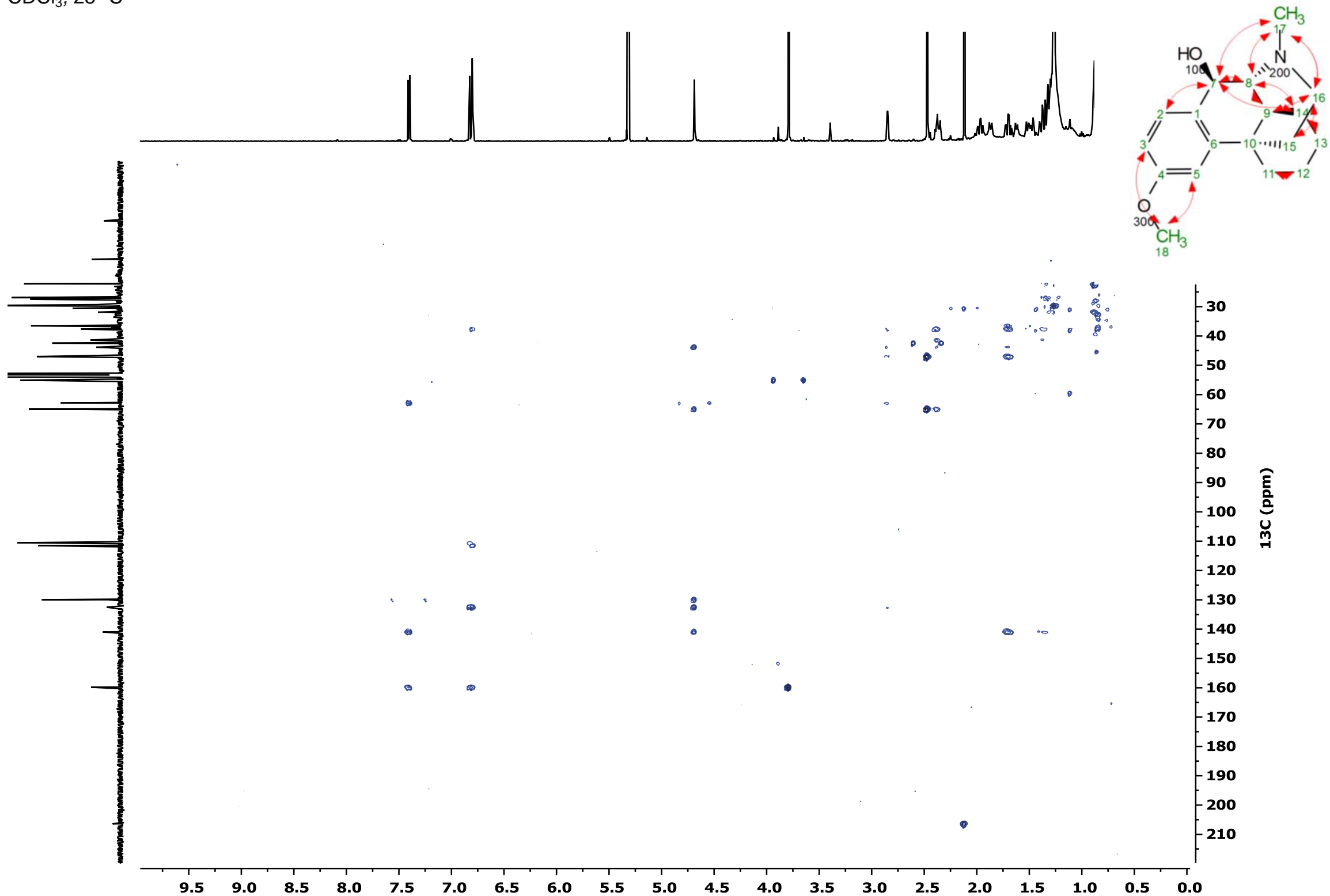


DEPT-ed-HSQC spectrum of hydroxylated-dextromethorphan derivative 15

$\mathrm{CDCl}_{3}, 25 \stackrel{\circ}{\circ} \mathrm{C}$

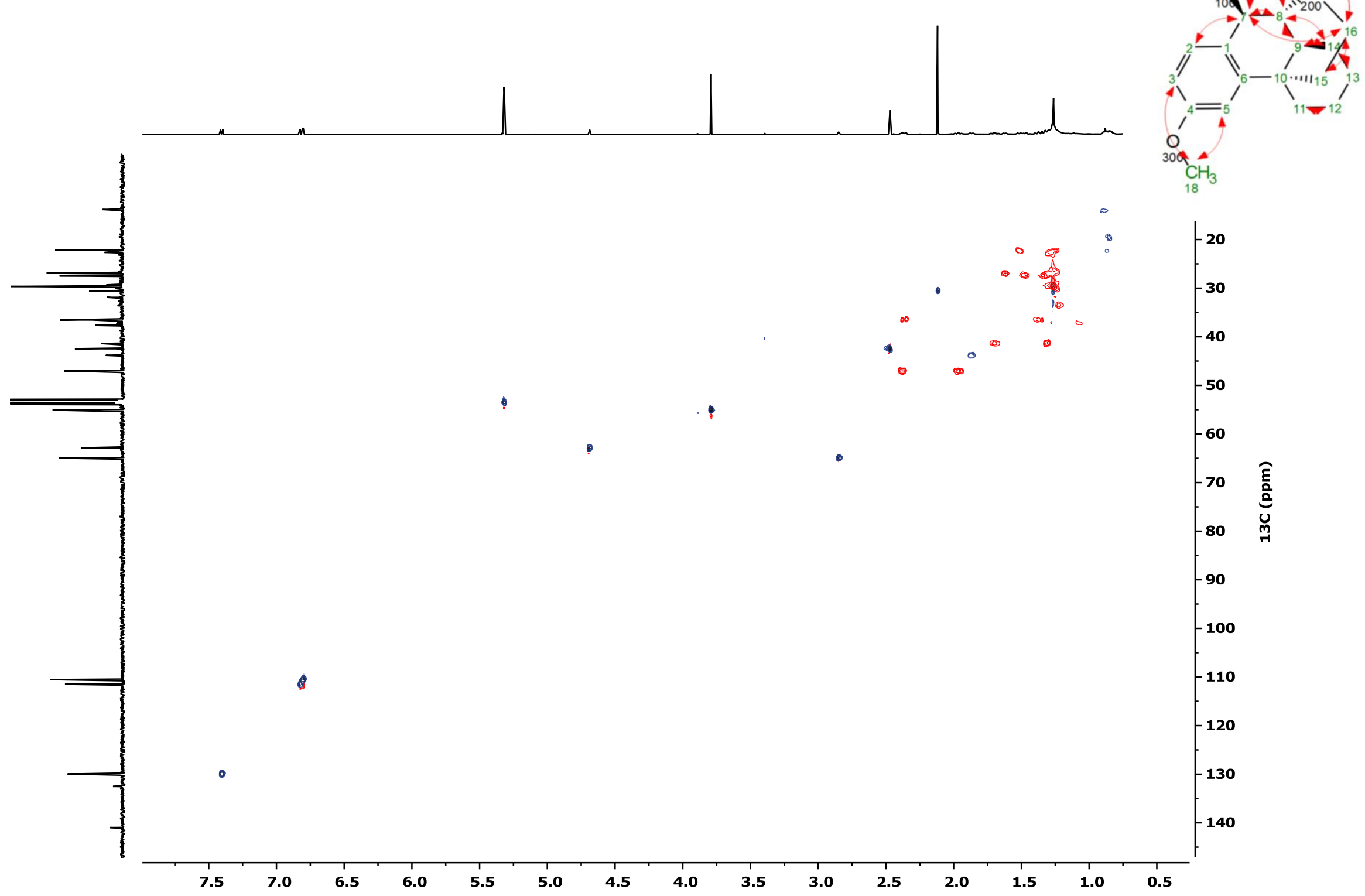




\section{$\mathrm{H}-\mathrm{H}$ NOESY of spectrum of hydroxylated-dextromethorphan derivative 15}

$\mathrm{CDCl}_{3}, 25 \stackrel{\circ}{\circ} \mathrm{C}$

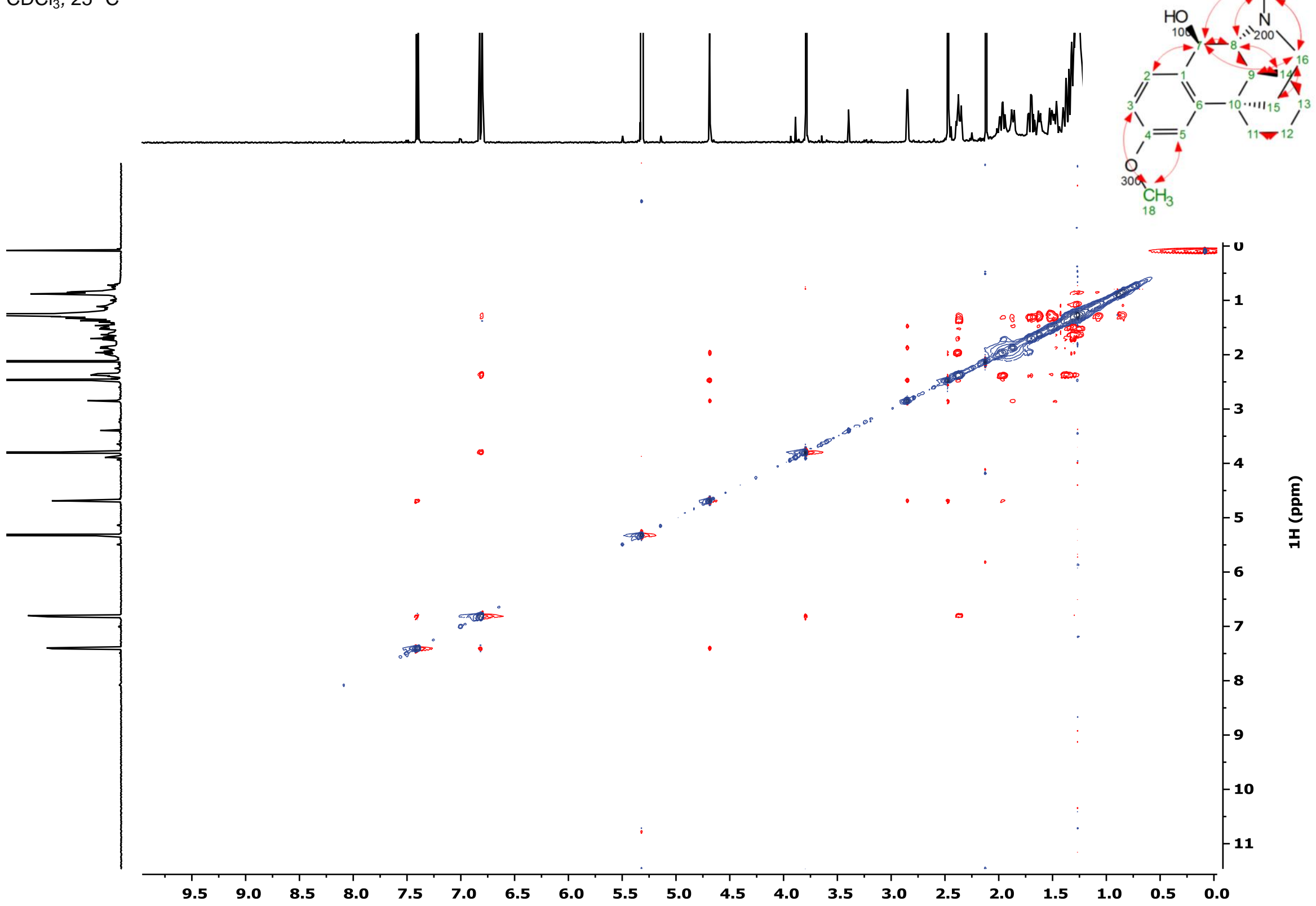


${ }^{1} \mathrm{H}$ NMR of $1^{\text {st }}$ step of 4-mesyloxy (phenyl)methyl-3-propionyl-2-oxazolidinone S37

$\mathrm{CDCl}_{3}, 25 \stackrel{\circ}{\mathrm{C}}, 500 \mathrm{MHz}$

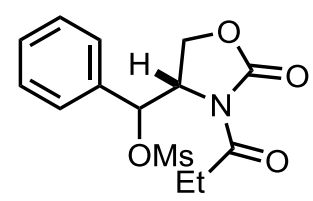

S37

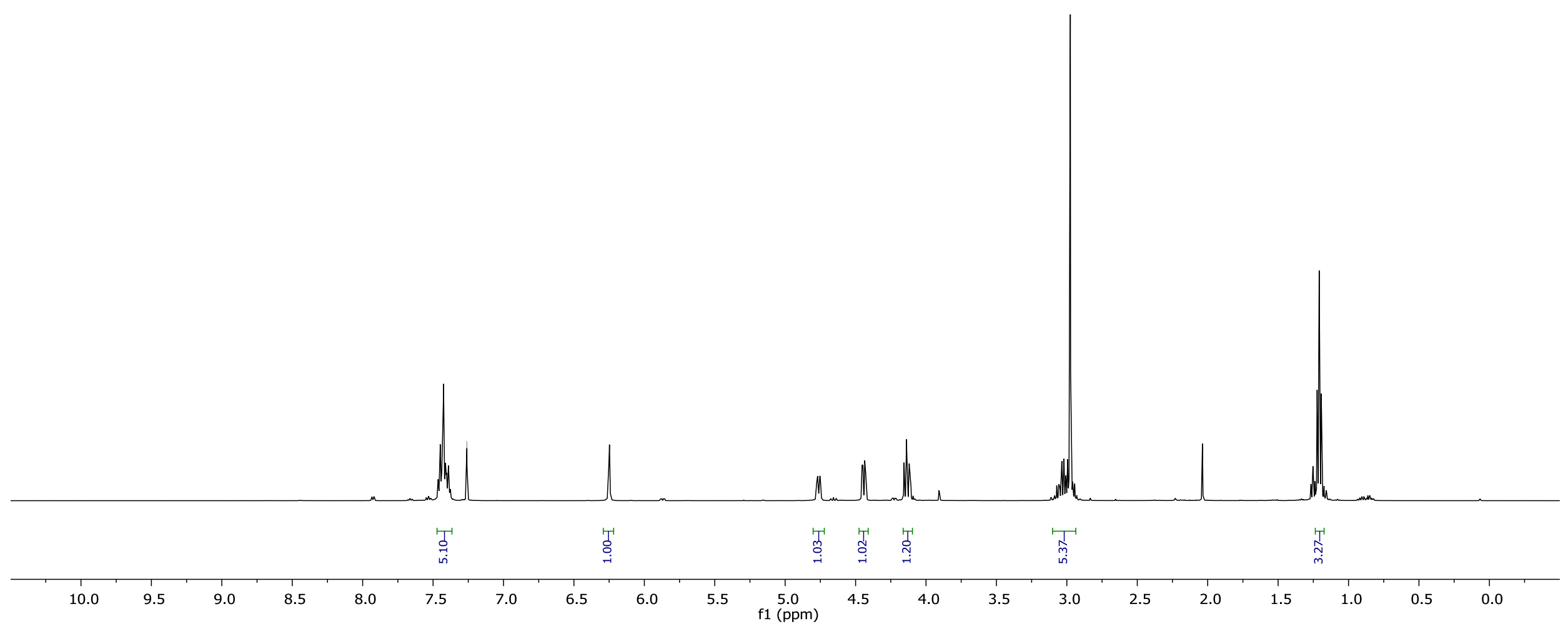


${ }^{1} \mathrm{H}$ NMR of 4-hydroxy (phenyl)methyl-3-propionyl-2-oxazolidinone 16

$\mathrm{CDCl}_{3}, 25 \stackrel{\circ}{\mathrm{C}}, 500 \mathrm{MHz}$

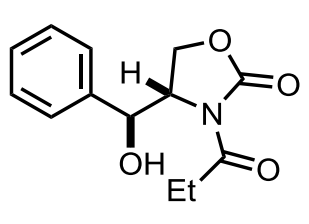

16

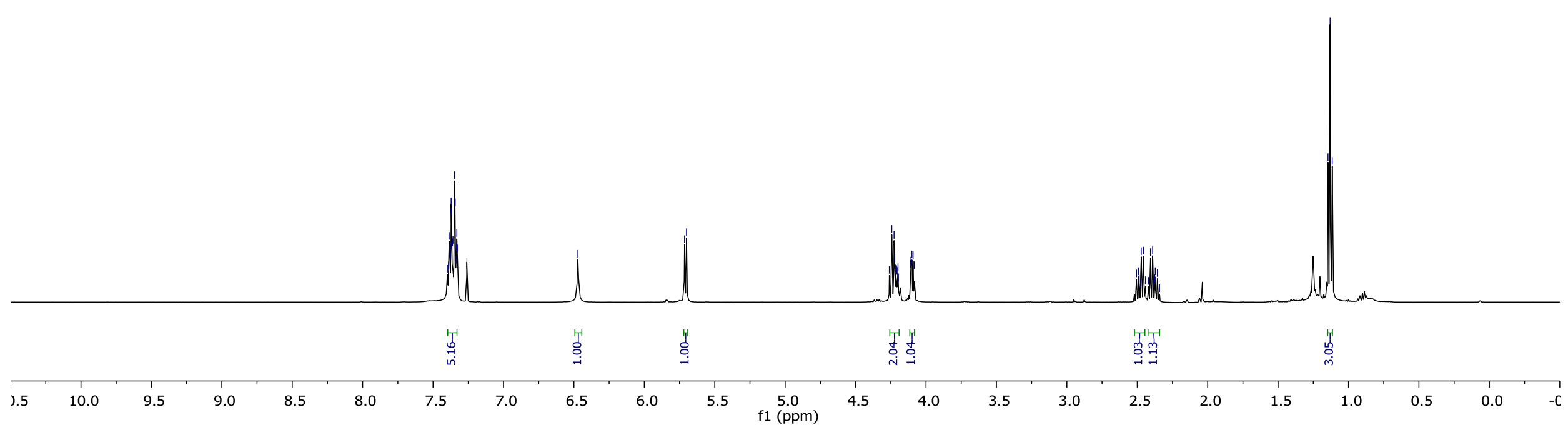


${ }^{13} \mathrm{C}$ NMR of 4-hydroxy (phenyl)methyl-3-propionyl-2-oxazolidinone 16

$\mathrm{CDCl}_{3}, 25 \stackrel{\circ}{\circ} \mathrm{C}, 126 \mathrm{~Hz}$

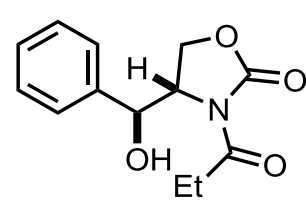

16

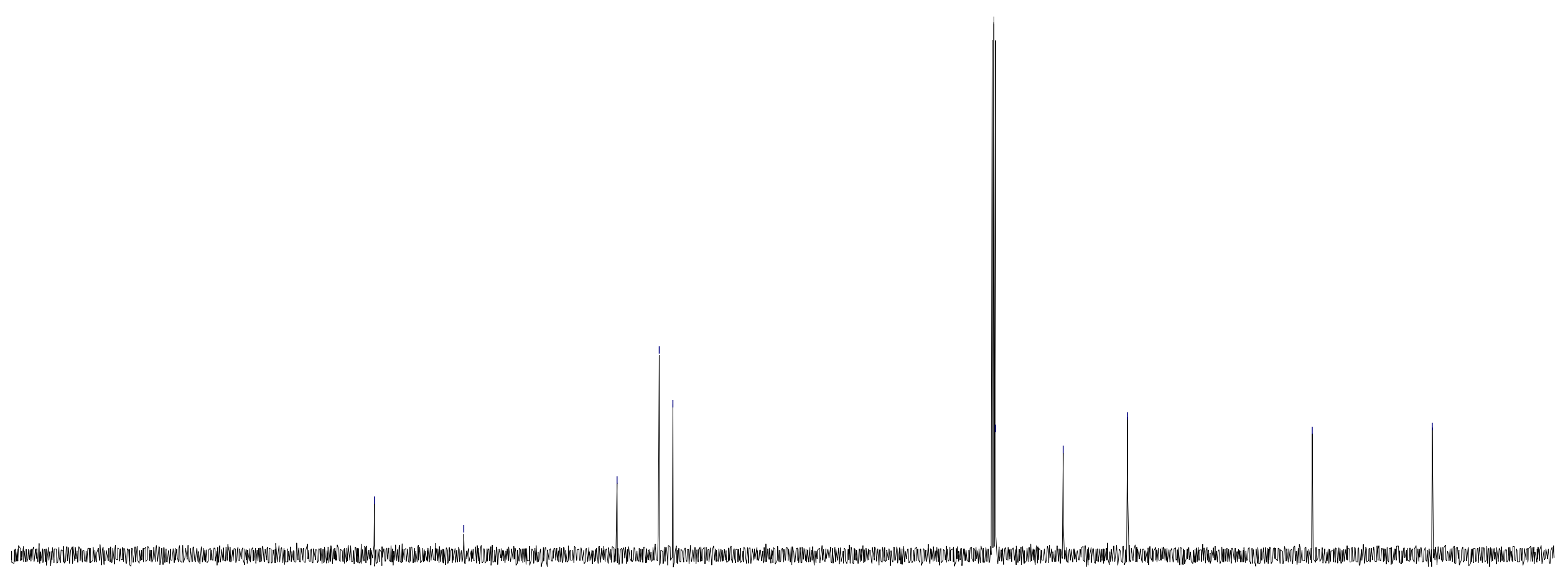

$30 \quad 220 \quad 210 \quad 200 \quad 190 \quad 180 \quad 170 \quad 160$ 
${ }^{1} \mathrm{H}$ NMR of benzoate derivative of 4-hydroxy (phenyl)methyl-3-propionyl-2-oxazolidinone 16A

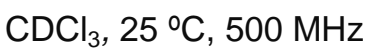
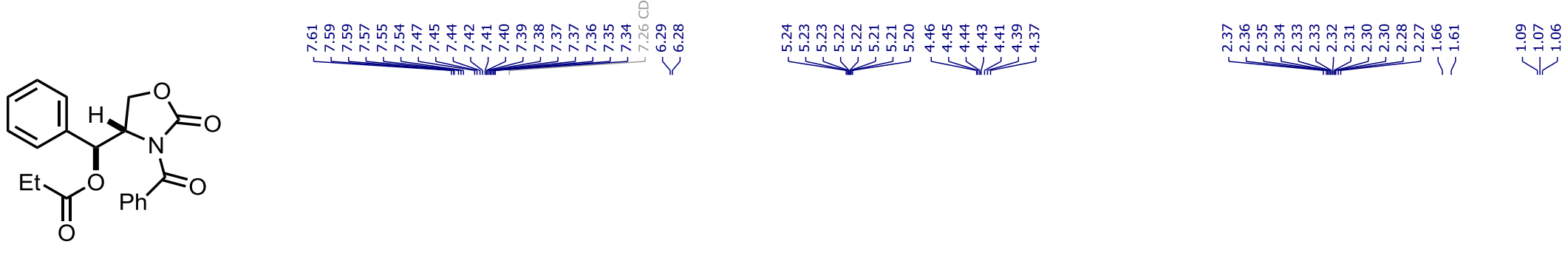

$16 A$

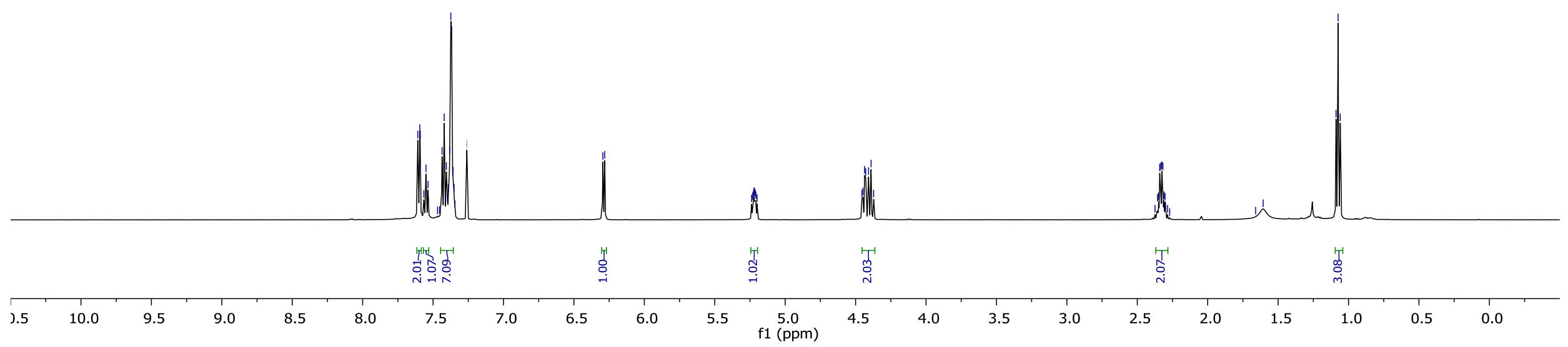


${ }^{1} \mathrm{H}$ NMR of pyridyl substituted $\alpha, \beta$-epoxy carbonyl hydroxy analogue 17A

$\left(\mathrm{CD}_{3}\right)_{2} \mathrm{SO}, 25^{\circ} \mathrm{C}, 500 \mathrm{MHz}$
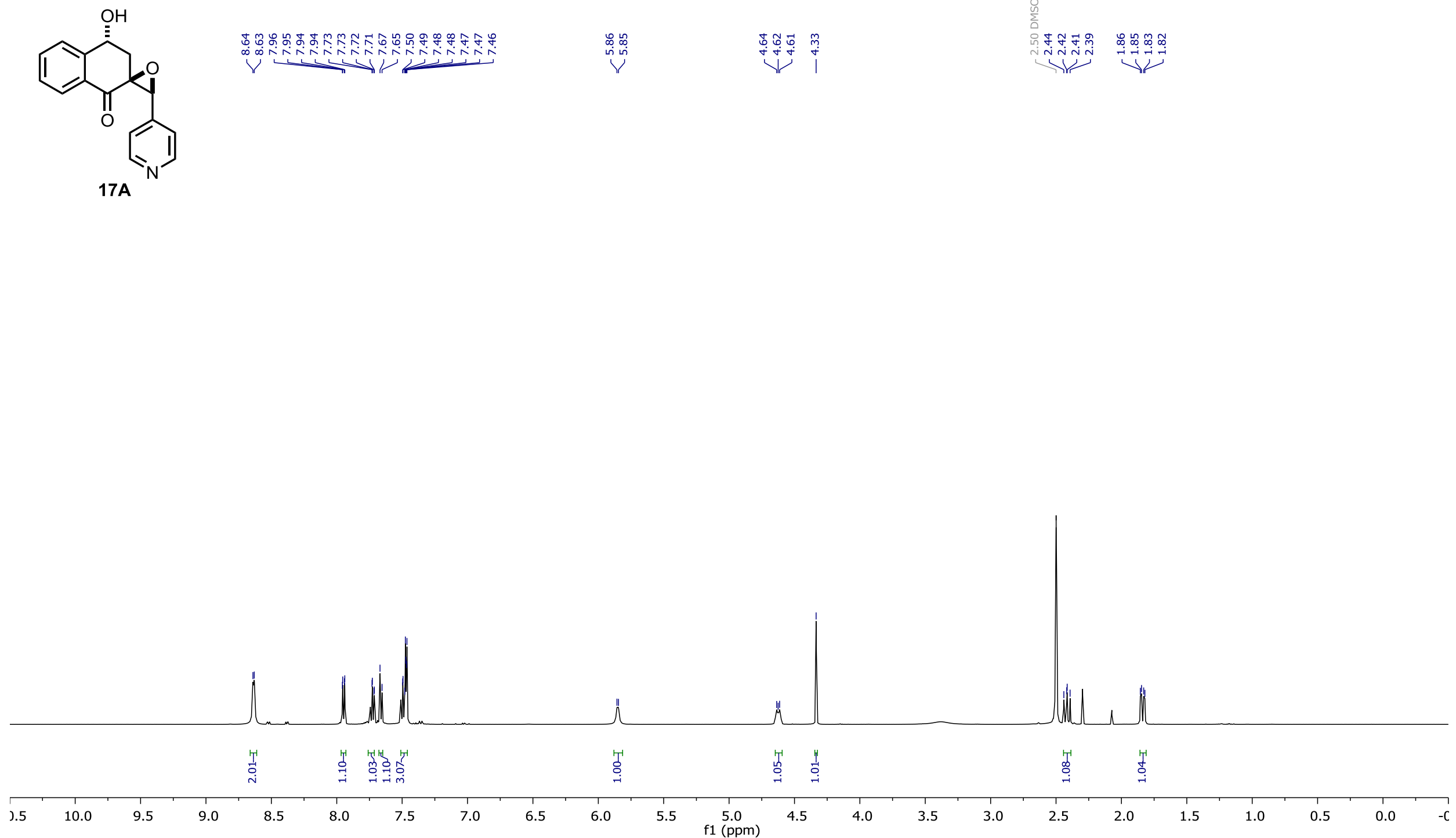
${ }^{13} \mathrm{C}$ NMR of pyridyl substituted $\alpha, \beta$-epoxy carbonyl hydroxy analogue 17A

$\left(\mathrm{CD}_{3}\right)_{2} \mathrm{SO}, 25 \stackrel{\circ}{\circ} \mathrm{C}, 126 \mathrm{~Hz}$

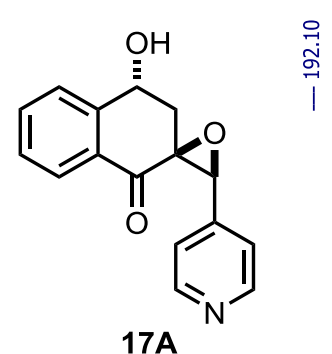

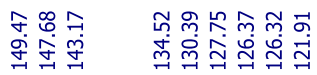

店

$17 A$

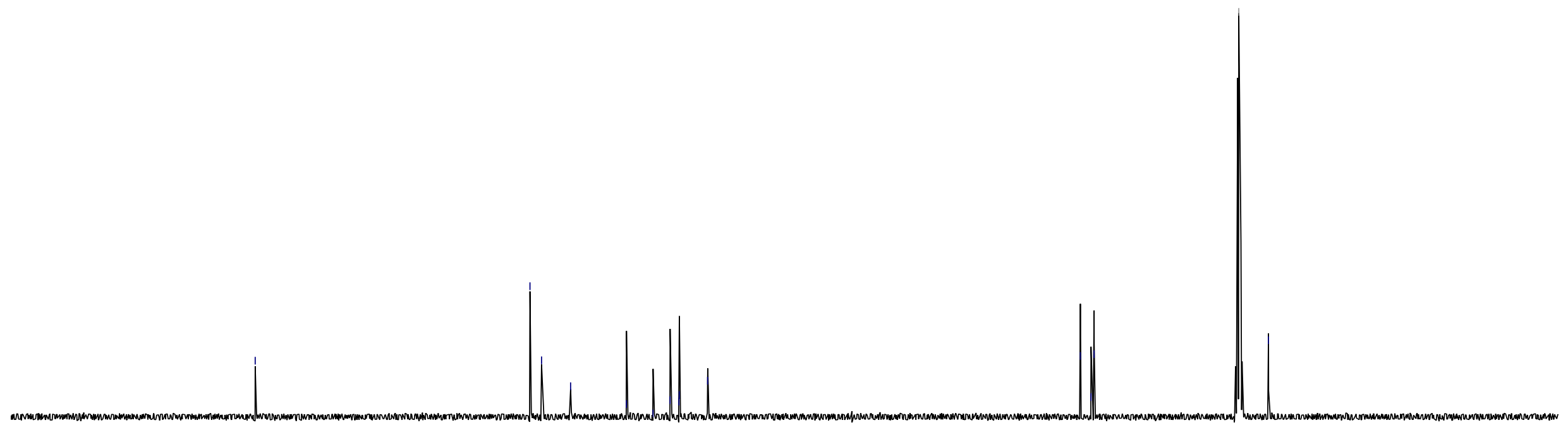




\section{2-D NOESY spectrum of pyridyl substituted $\alpha, \beta$-epoxy carbonyl hydroxy analogue 17A}

$\left(\mathrm{CD}_{3}\right)_{2} \mathrm{SO}, 25^{\circ} \mathrm{C}$

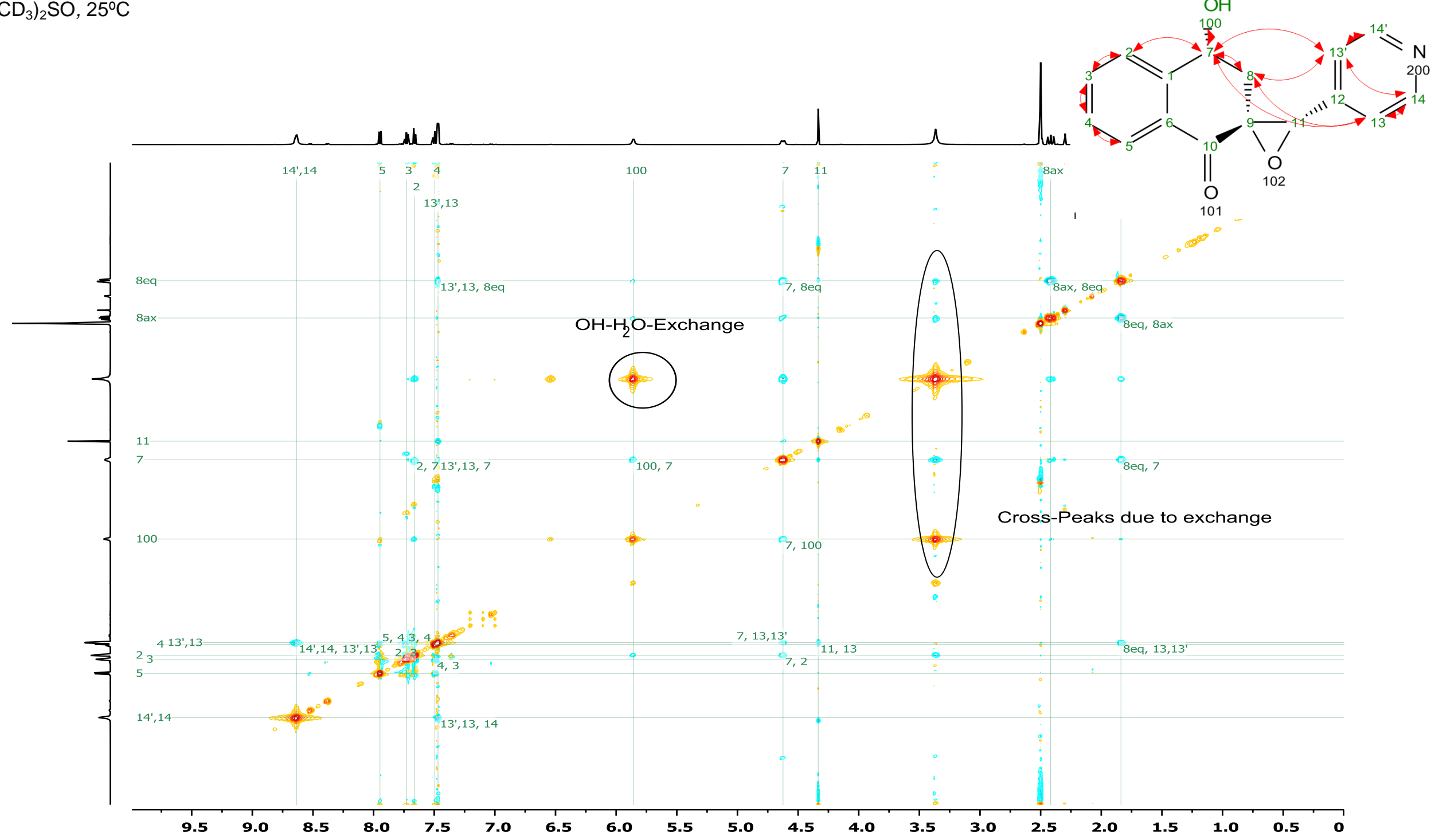


2-D HSQC spectrum of pyridyl substituted $\alpha, \beta$-epoxy carbonyl hydroxy analogue 17A

$\left(\mathrm{CD}_{3}\right)_{2} \mathrm{SO}, 25^{\circ} \mathrm{C}$

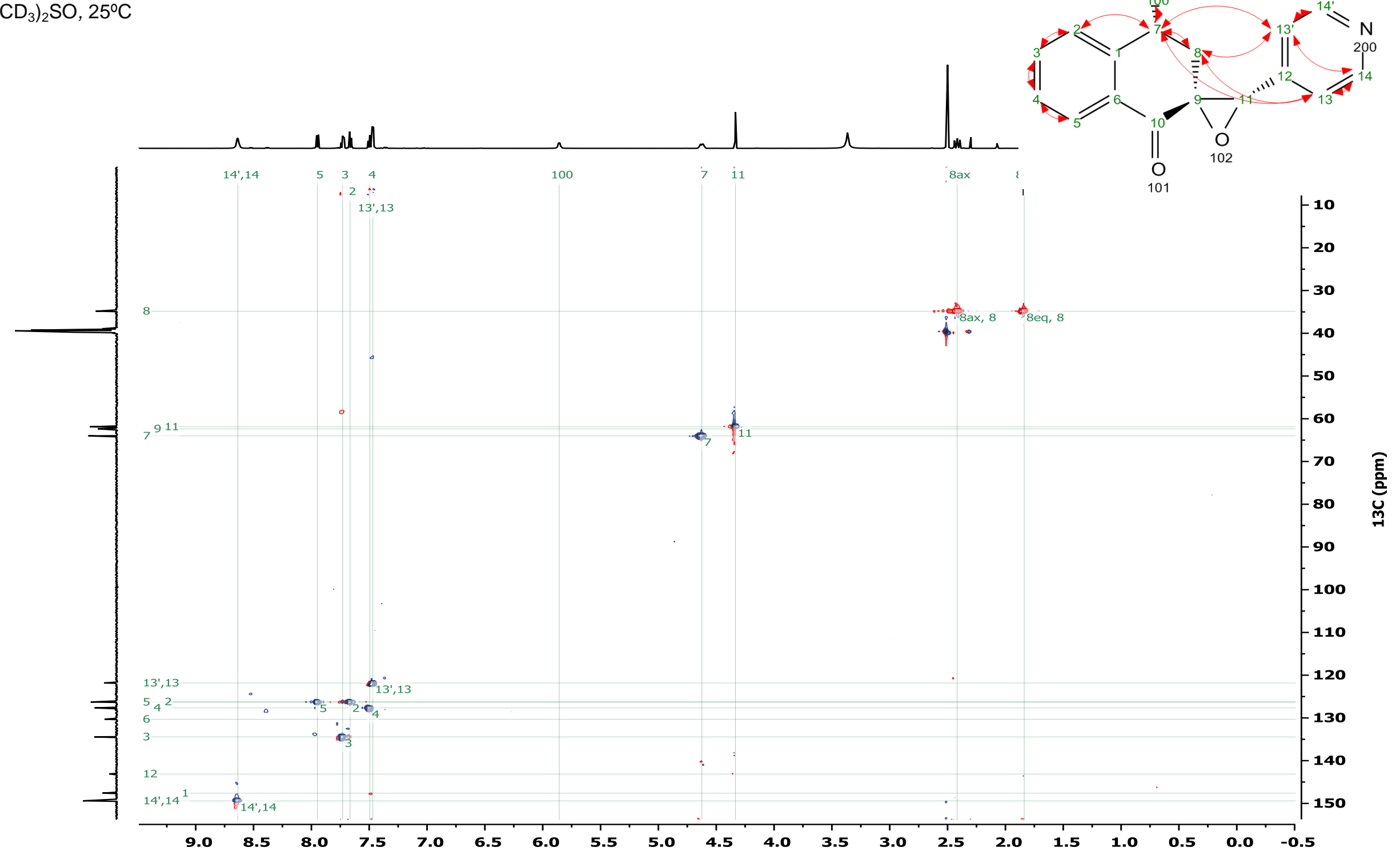


2-D HMBC spectrum of pyridyl substituted $\alpha, \beta$-epoxy carbonyl hydroxy analogue 17A

$\left(\mathrm{CD}_{3}\right)_{2} \mathrm{SO}, 25^{\circ} \mathrm{C}$

2D HMBC

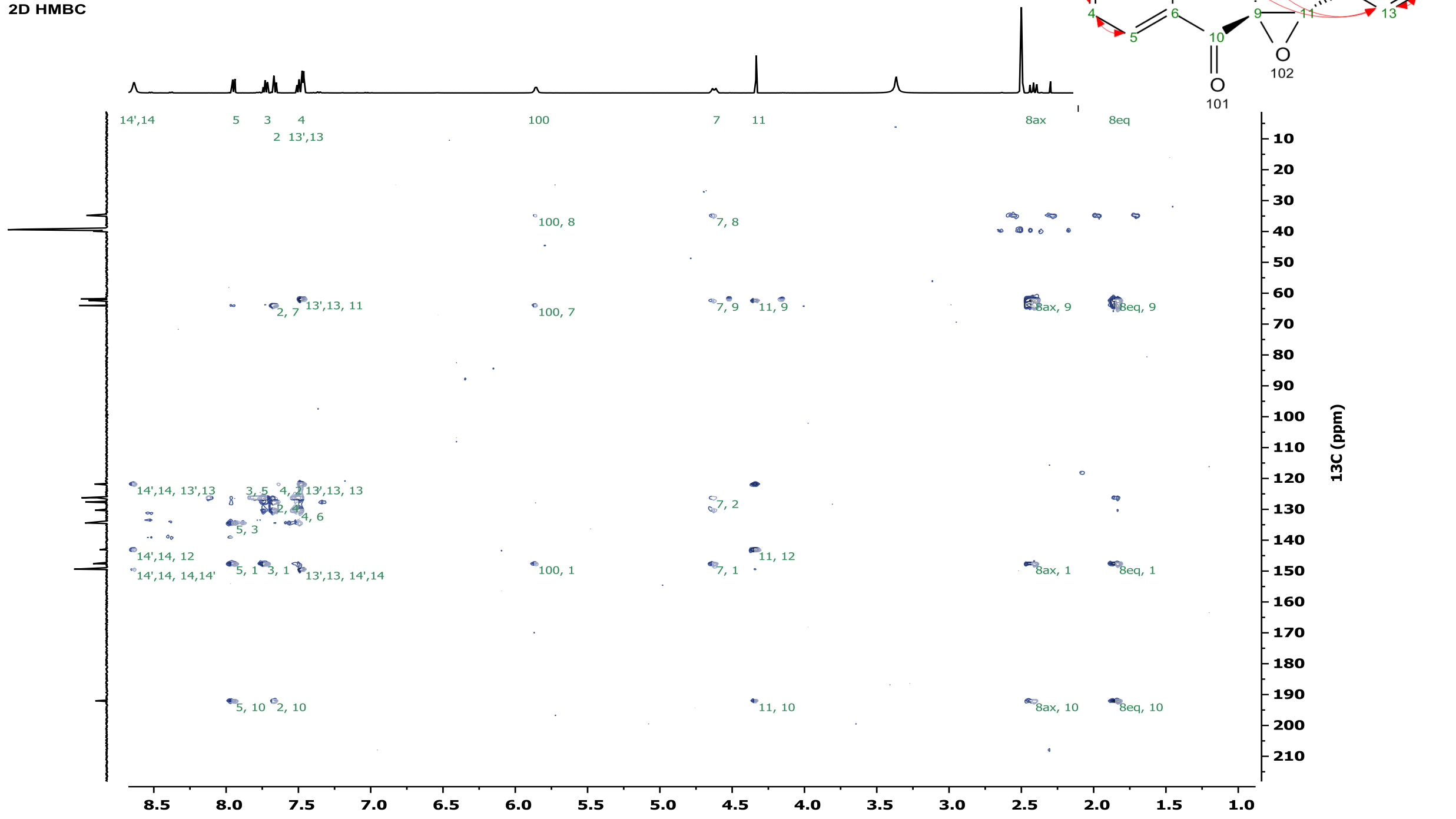


${ }^{1} \mathrm{H}$ NMR of pyridyl substituted $\alpha, \beta$-epoxy carbonyl hydroxy analogue 17B

$\left(\mathrm{CD}_{3}\right)_{2} \mathrm{SO}, 25 \stackrel{\circ}{\mathrm{C}}, 500 \mathrm{MHz}$

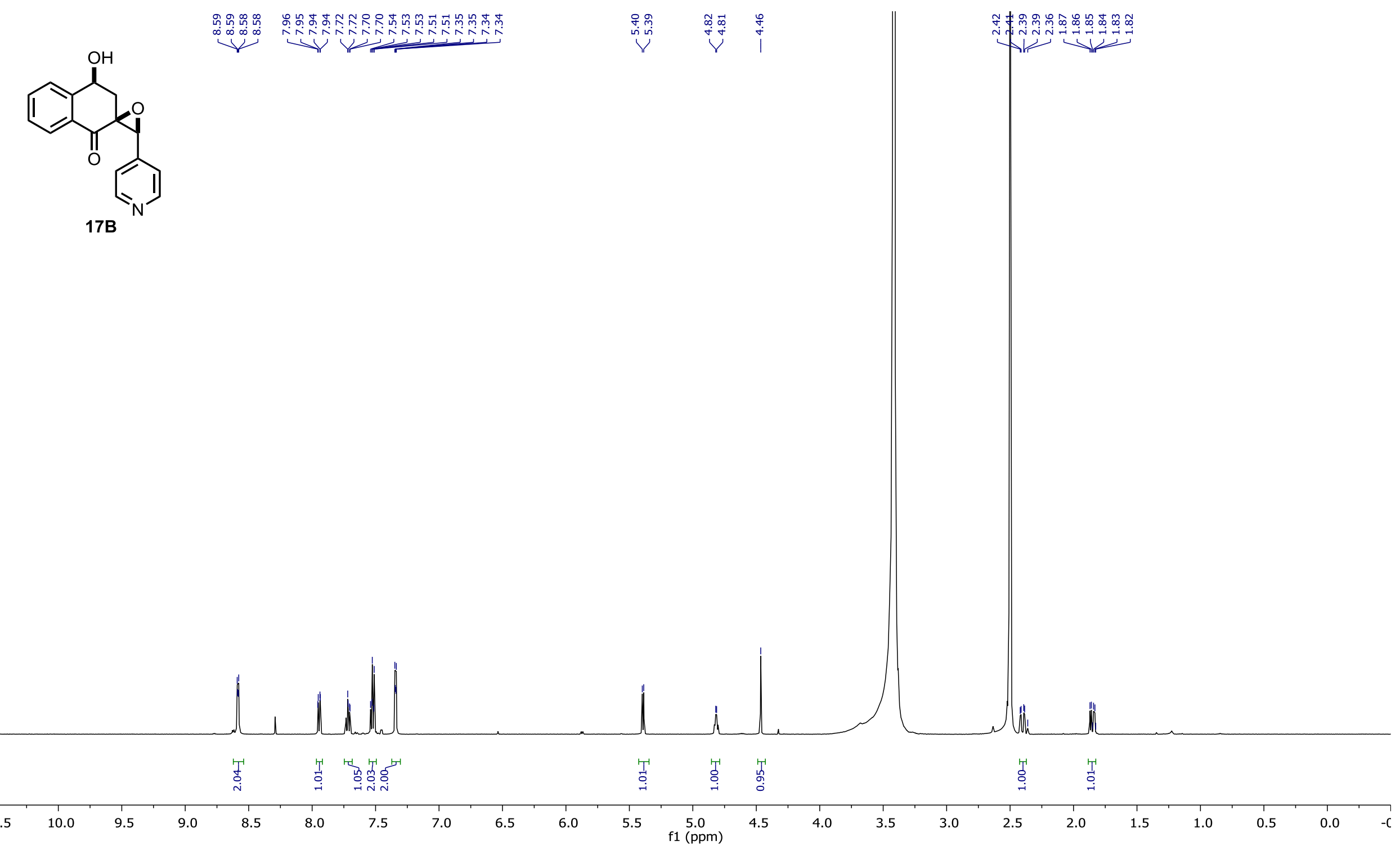


${ }^{13} \mathrm{C}$ NMR of pyridyl substituted $\alpha, \beta$-epoxy carbonyl hydroxy analogue 17B

$\left(\mathrm{CD}_{3}\right)_{2} \mathrm{SO}, 25 \stackrel{\circ}{\circ}, 126 \mathrm{~Hz}$
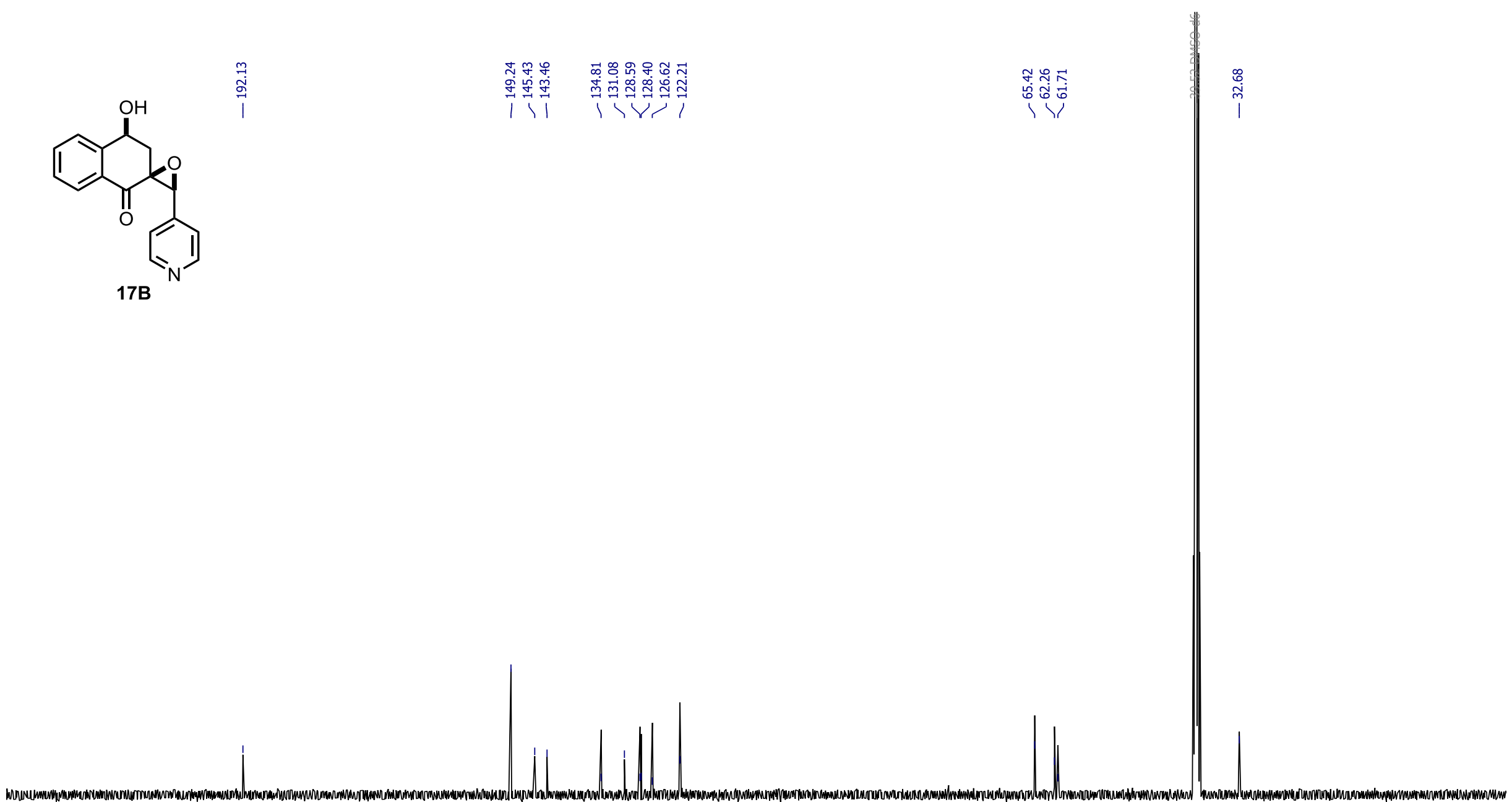
2-D NOESY spectrum of pyridyl substituted $\alpha, \beta$-epoxy carbonyl hydroxy analogue 17B

$\left(\mathrm{CD}_{3}\right)_{2} \mathrm{SO}, 25^{\circ} \mathrm{C}$

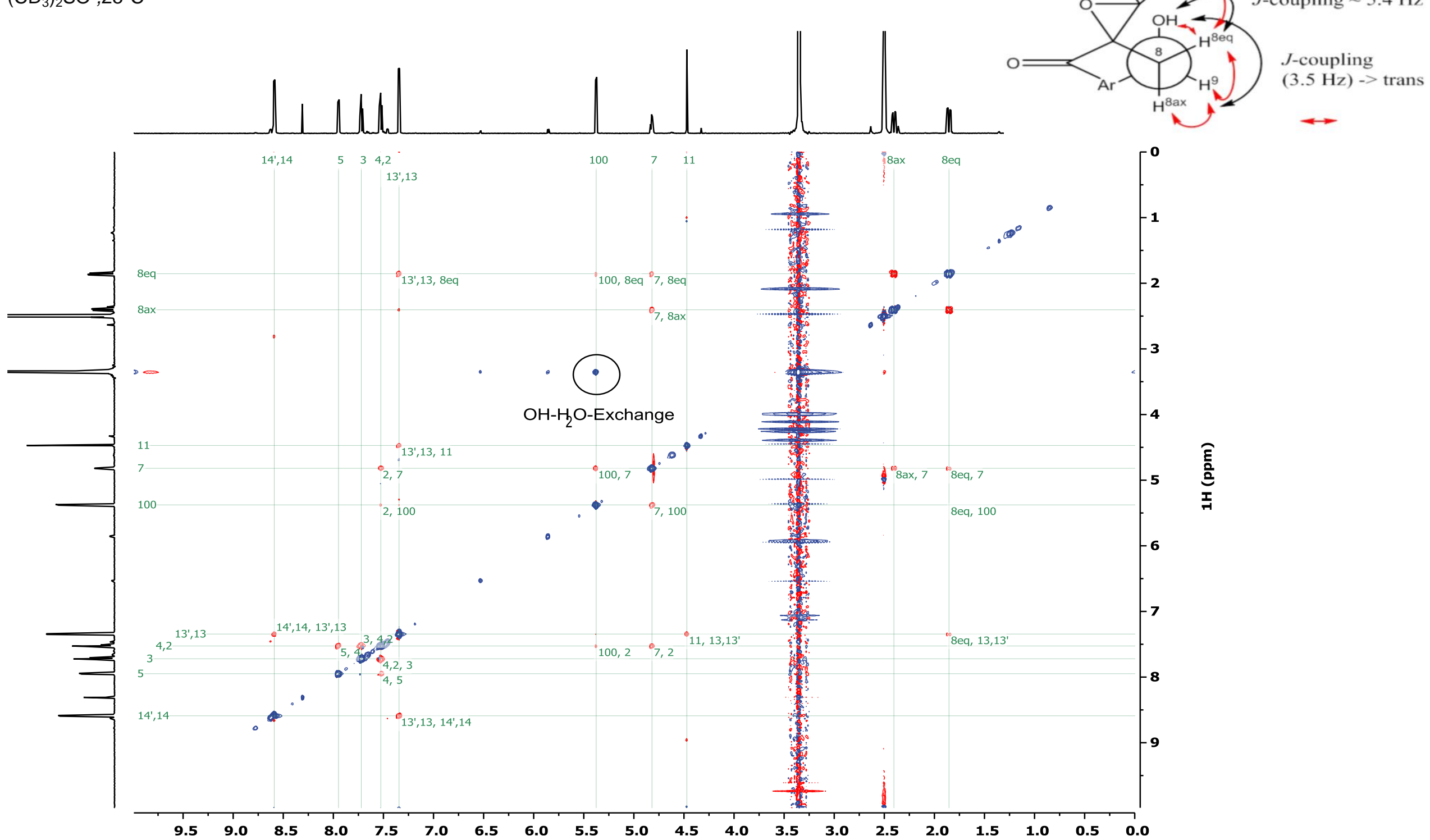




\section{2-D HSQC spectrum of pyridyl substituted $\alpha, \beta$-epoxy carbonyl hydroxy analogue 17B}

$\left(\mathrm{CD}_{3}\right)_{2} \mathrm{SO}, 25^{\circ} \mathrm{C}$

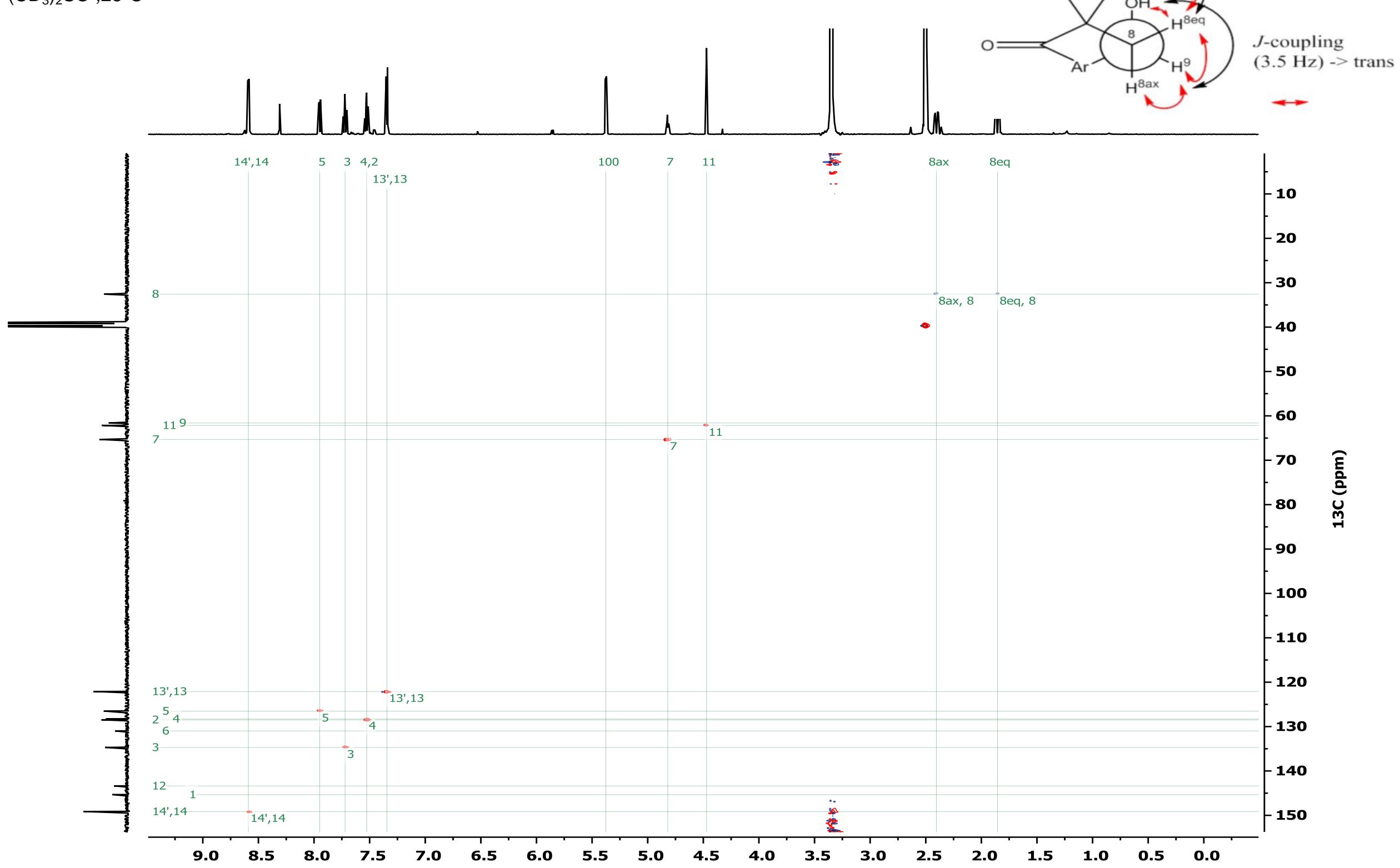


2-D HMBC spectrum of pyridyl substituted $\alpha, \beta$-epoxy carbonyl hydroxy analogue 17B

$\left(\mathrm{CD}_{3}\right)_{2} \mathrm{SO}, 25^{\circ} \mathrm{C}$

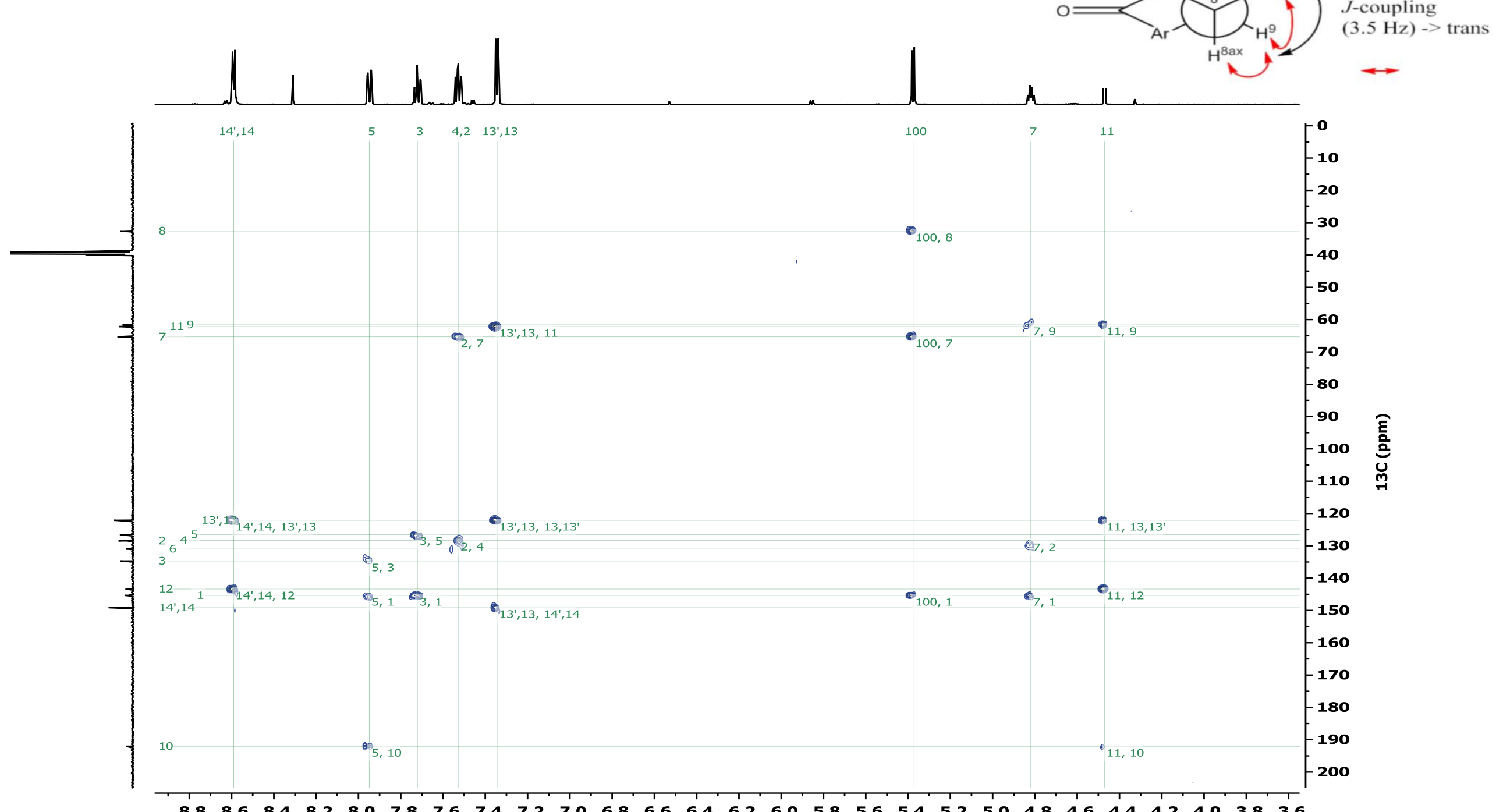


${ }^{1} \mathrm{H}$ NMR of 1-(4-(1H-pyrazol-1-yl)phenyl)ethan-1-ol (18)

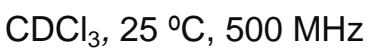

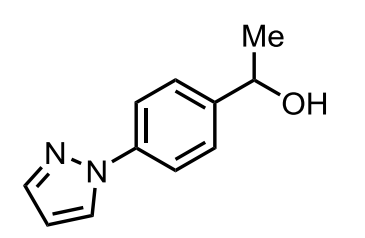

18

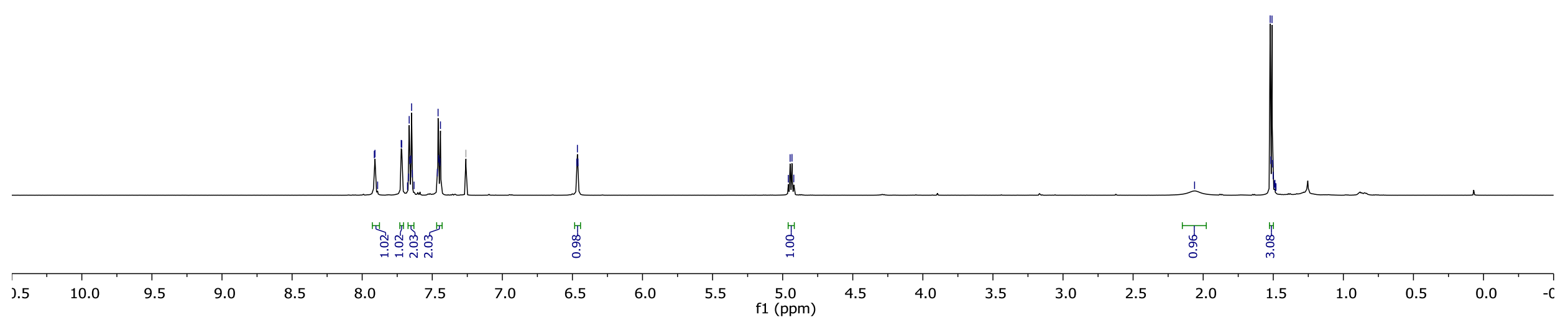


${ }^{13} \mathrm{C}$ NMR of 1-(4-(1H-pyrazol-1-yl)phenyl)ethan-1-ol (18)

$\mathrm{CDCl}_{3}, 25 \stackrel{\circ}{\mathrm{C}}, 126 \mathrm{MHz}$

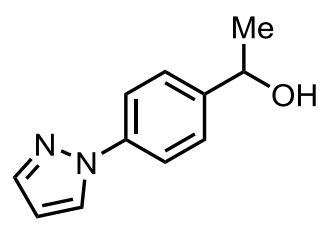

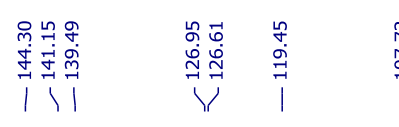

盟

18

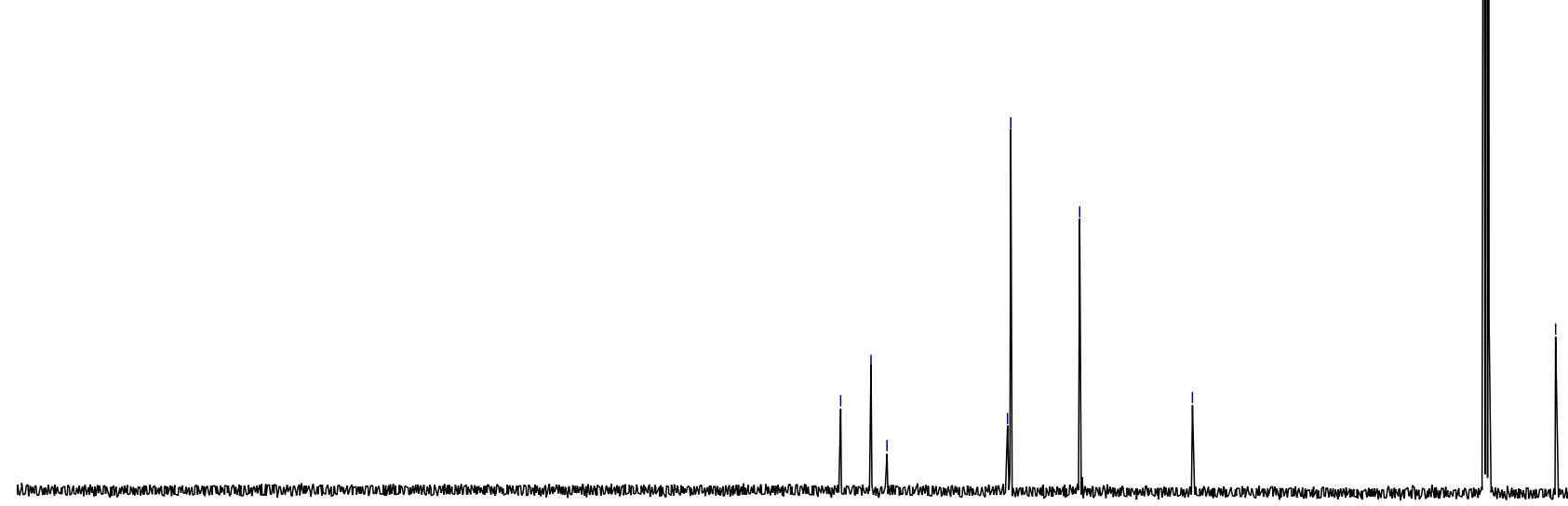

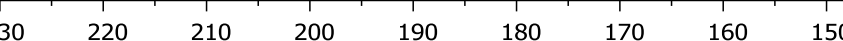

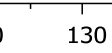


${ }^{1} \mathrm{H}$ NMR of 7-hydroxy-6,7-dihydrobenzofuran-4(5H)-one (19)

$\mathrm{CDCl}_{3}, 25 \stackrel{\circ}{\mathrm{C}}, 500 \mathrm{MHz}$
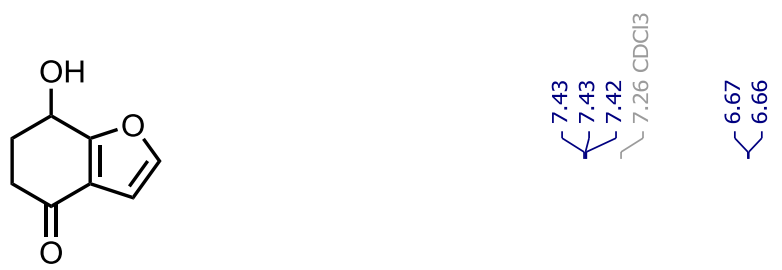

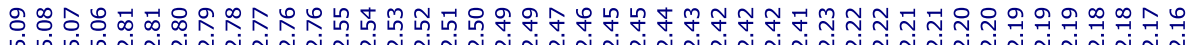
ம่

19

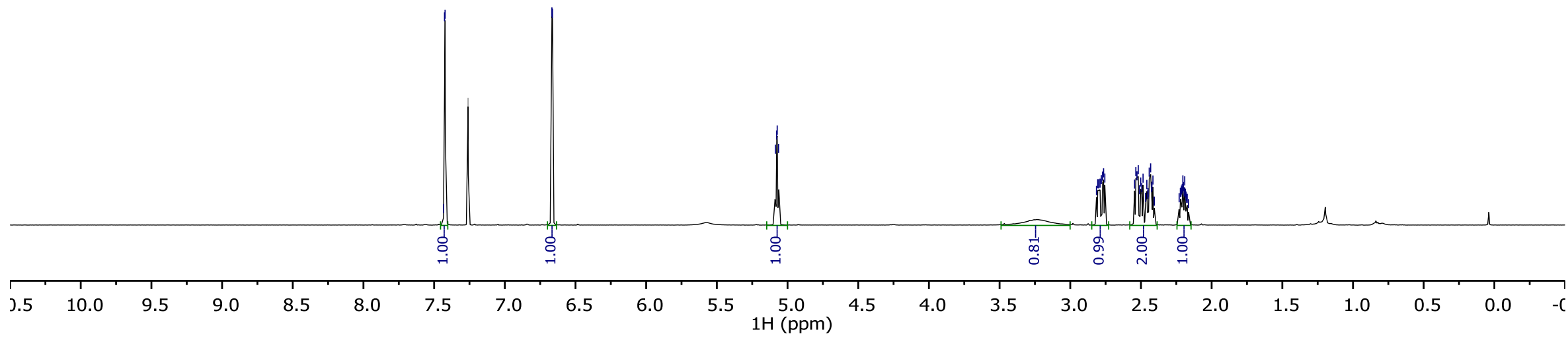


${ }^{13} \mathrm{C}$ NMR of 7-hydroxy-6,7-dihydrobenzofuran-4(5H)-one (19)

$\mathrm{CDCl}_{3}, 25 \stackrel{\circ}{\mathrm{C}}, 126 \mathrm{MHz}$

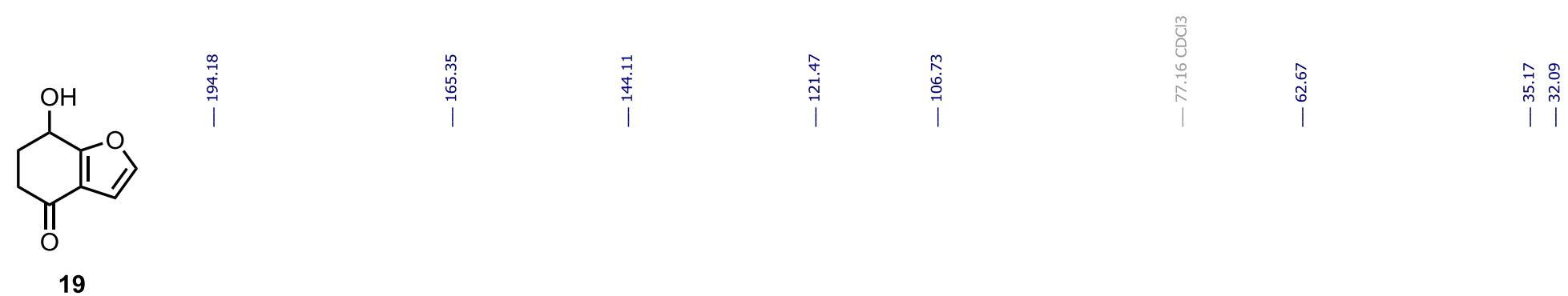

19

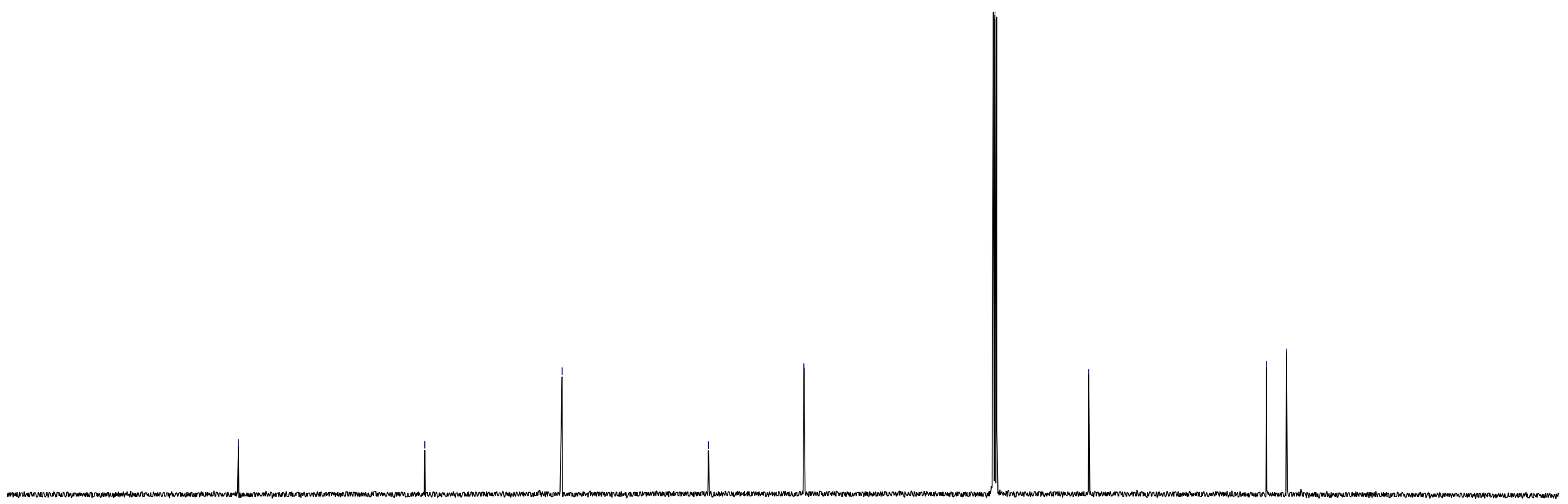

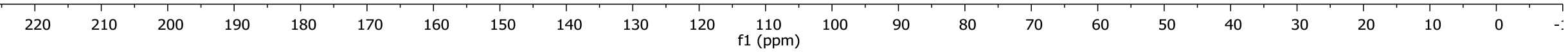


${ }^{1} \mathrm{H}$ NMR of 5-(1-hydroxyethyl)thiophene-2-carbaldehyde (20)

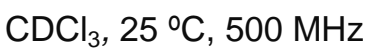

$\infty$

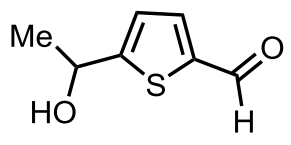

20

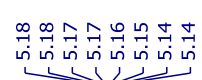

i

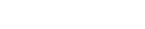

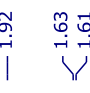

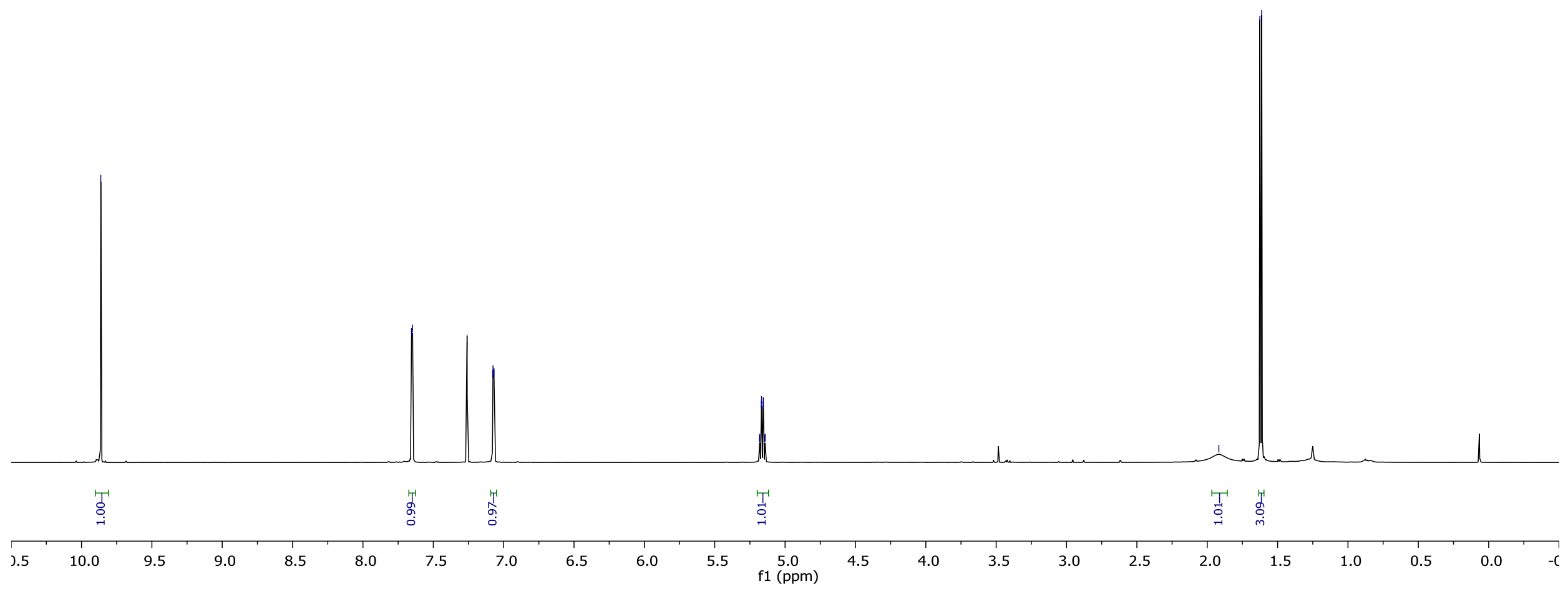


${ }^{13} \mathrm{C}$ NMR of 5-(1-hydroxyethyl)thiophene-2-carbaldehyde (20)

$\mathrm{CDCl}_{3}, 25 \stackrel{\circ}{\mathrm{C}}, 126 \mathrm{MHz}$

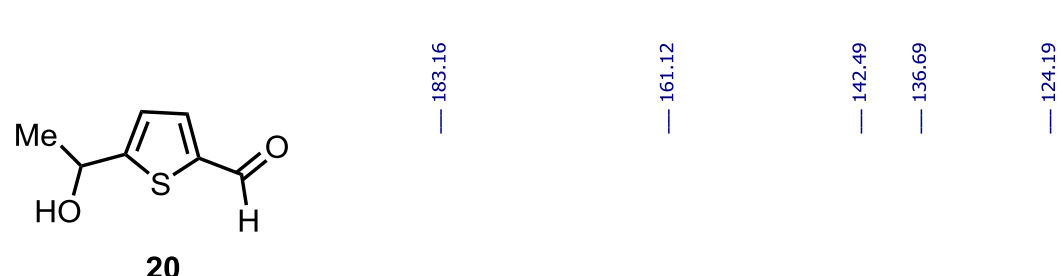

20 


\section{${ }^{1} \mathrm{H}$ NMR of Hydroxylated celecoxib derivative 21}

$\mathrm{CD}_{2} \mathrm{Cl}_{2}, 25 \stackrel{\circ}{\circ}, 500 \mathrm{MHz}$

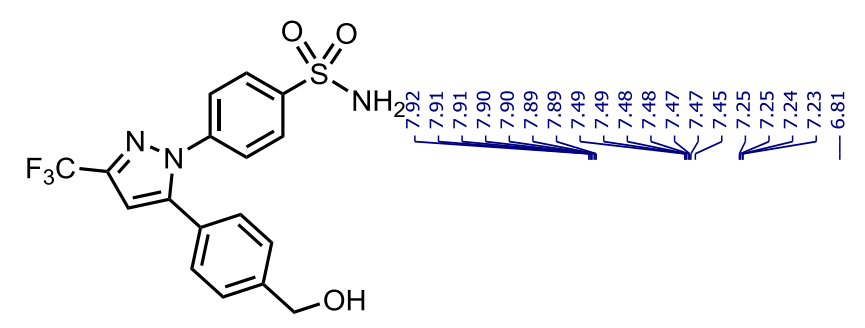

21

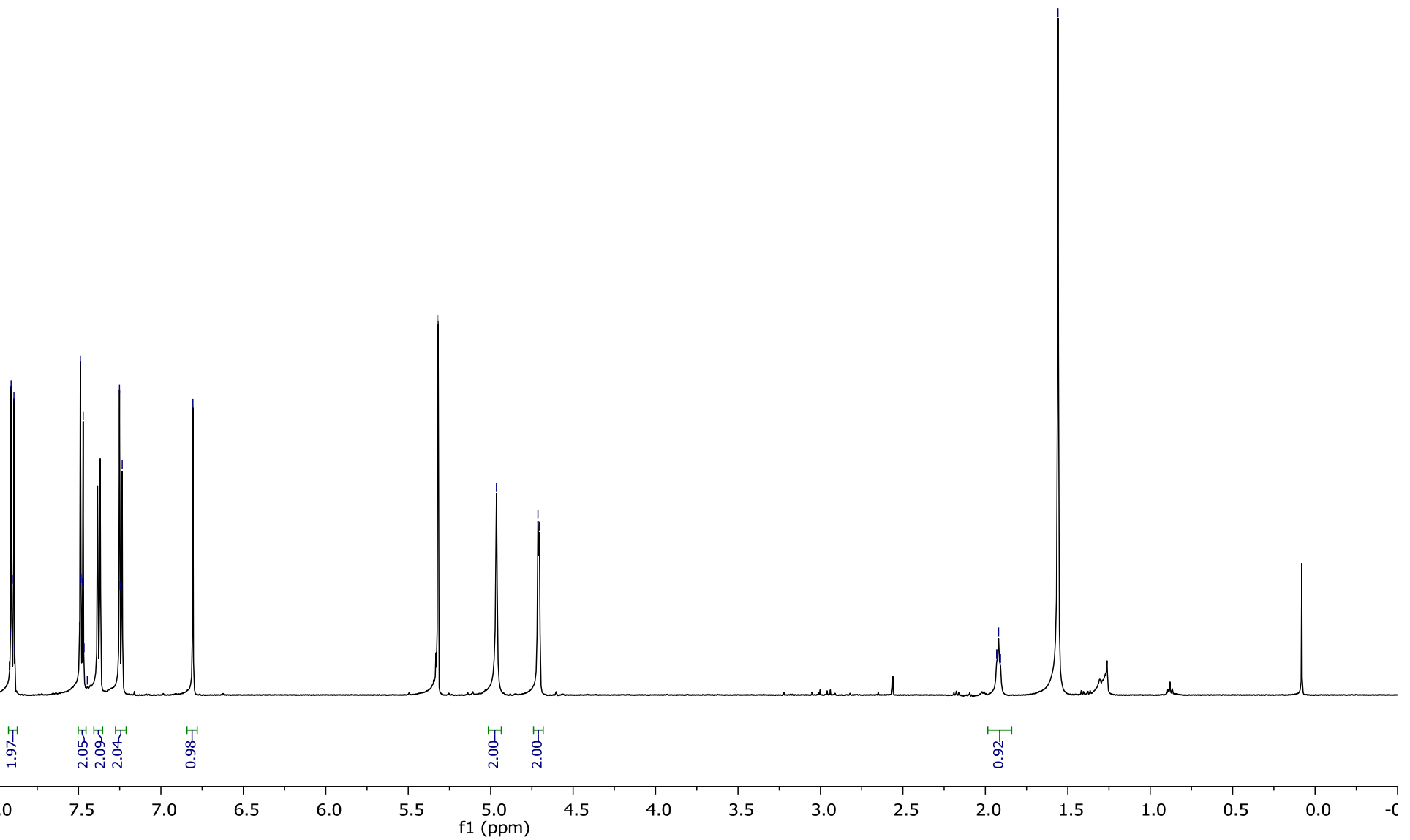


${ }^{13} \mathrm{C}$ NMR of Hydroxylated celecoxib derivative 21

$\mathrm{CD}_{2} \mathrm{Cl}_{2}, 25 \stackrel{\circ}{\circ} \mathrm{C}, 126 \mathrm{~Hz}$
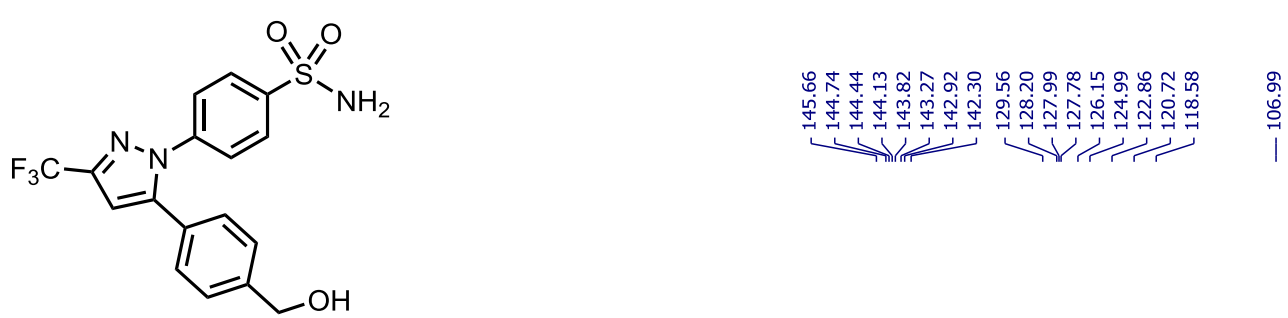

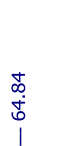

21

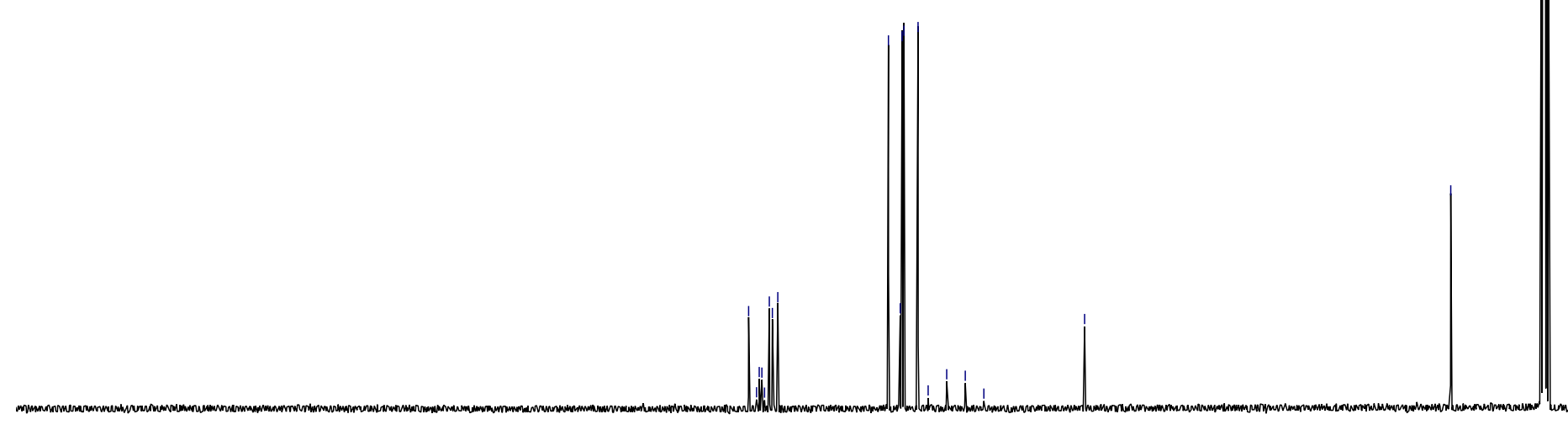

$220 \quad 210$ 
${ }^{19}$ F NMR of Hydroxylated celecoxib derivative 21

$\mathrm{CD}_{2} \mathrm{Cl}_{2}, 25 \stackrel{\circ}{\circ} \mathrm{C}, 471 \mathrm{~Hz}$

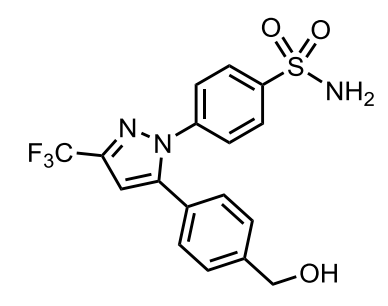

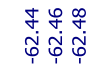

21

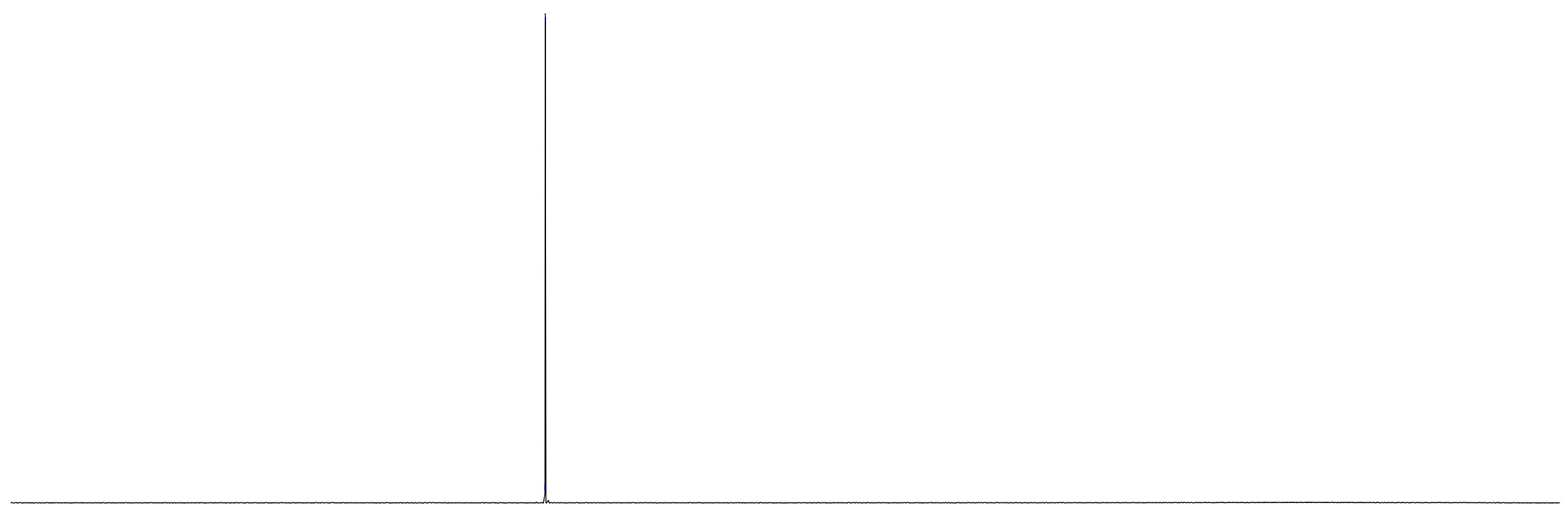

0

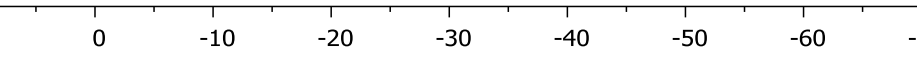

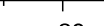

$-90-100$

$-110 \quad-120$

$-130 \quad-140$

$-150 \quad-160$ 
${ }^{1} \mathrm{H}$ NMR of 4,4 -difluorobenzhydrol (S20A)

$\mathrm{CDCl}_{3}, 25 \stackrel{\circ}{\mathrm{C}}, 500 \mathrm{MHz}$
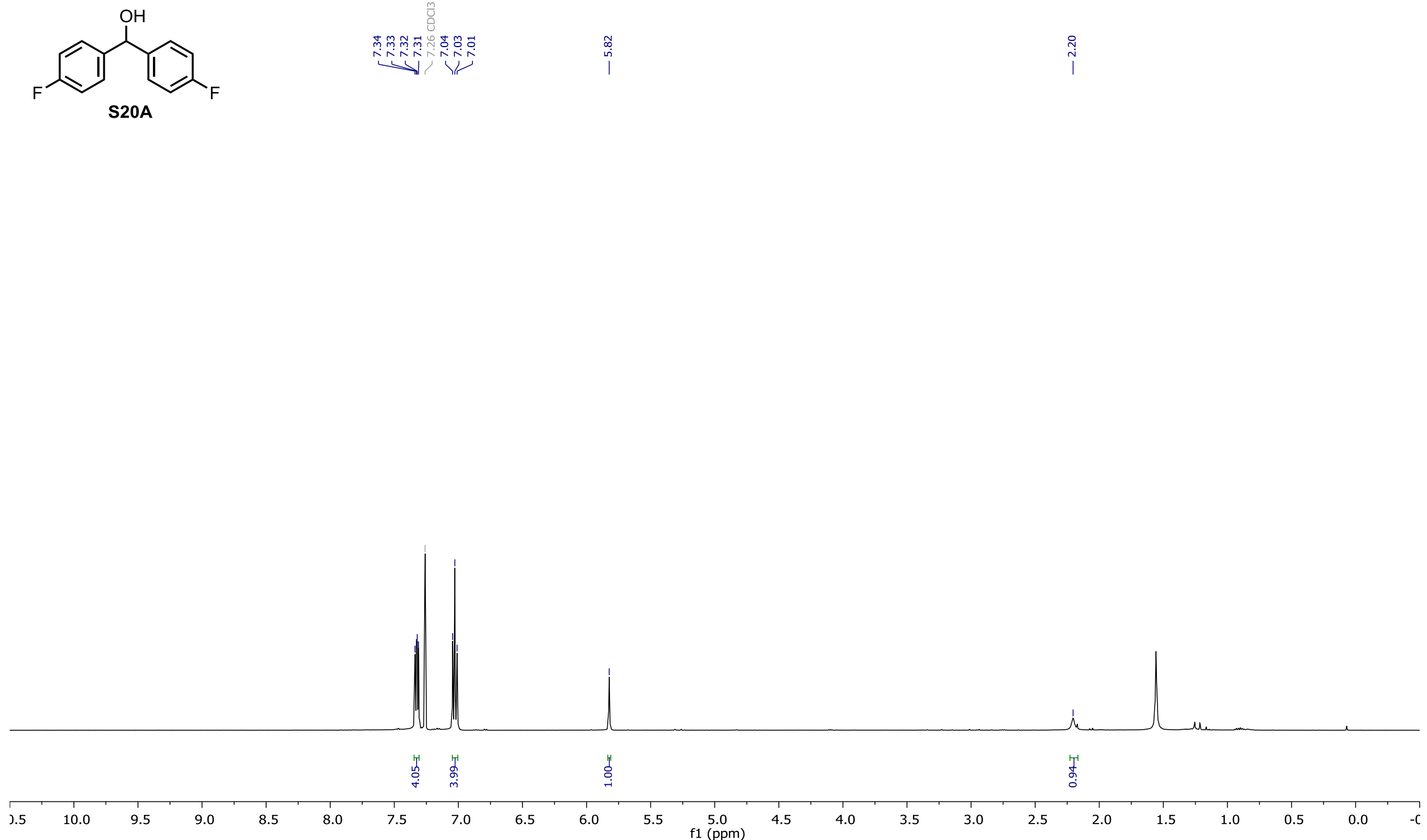
${ }^{13} \mathrm{C}$ NMR of $4,4^{`}$-difluorobenzhydrol (S20A)

$\mathrm{CDCl}_{3}, 25 \stackrel{\circ}{\mathrm{C}}, 126 \mathrm{~Hz}$

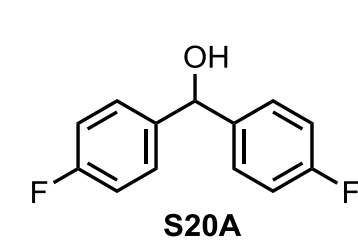

\begin{tabular}{|c|c|c|}
\hline 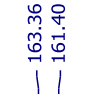 & 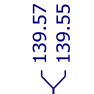 & 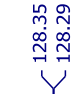 \\
\hline
\end{tabular}

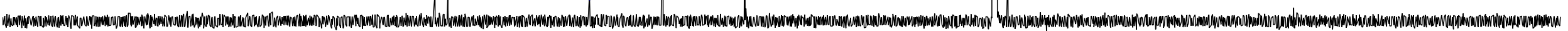

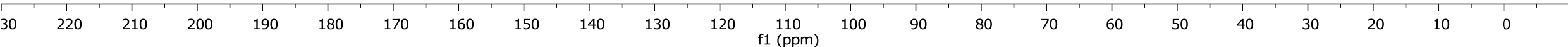


${ }^{19}$ F NMR of 4,4'-difluorobenzhydrol (S20A)

$\mathrm{CDCl}_{3}, 25 \stackrel{\circ}{\mathrm{C}}, 471 \mathrm{MHz}$

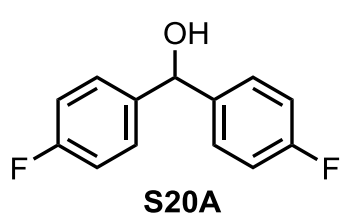

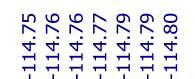

穴

S20A

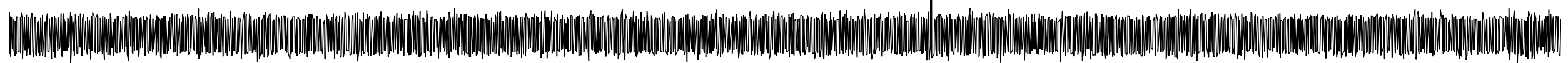

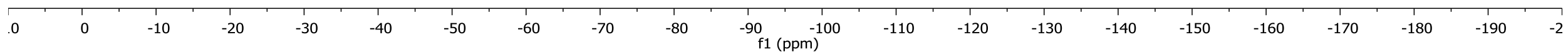


${ }^{1} \mathrm{H}$ NMR of 4,4'-difluorbenzophenone (S20B)

$\mathrm{CDCl}_{3}, 25^{\circ} \mathrm{C}, 500 \mathrm{MHz}$
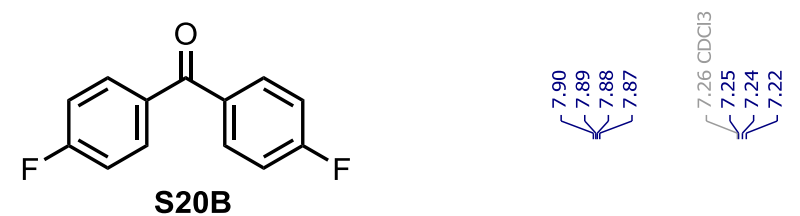

S20B

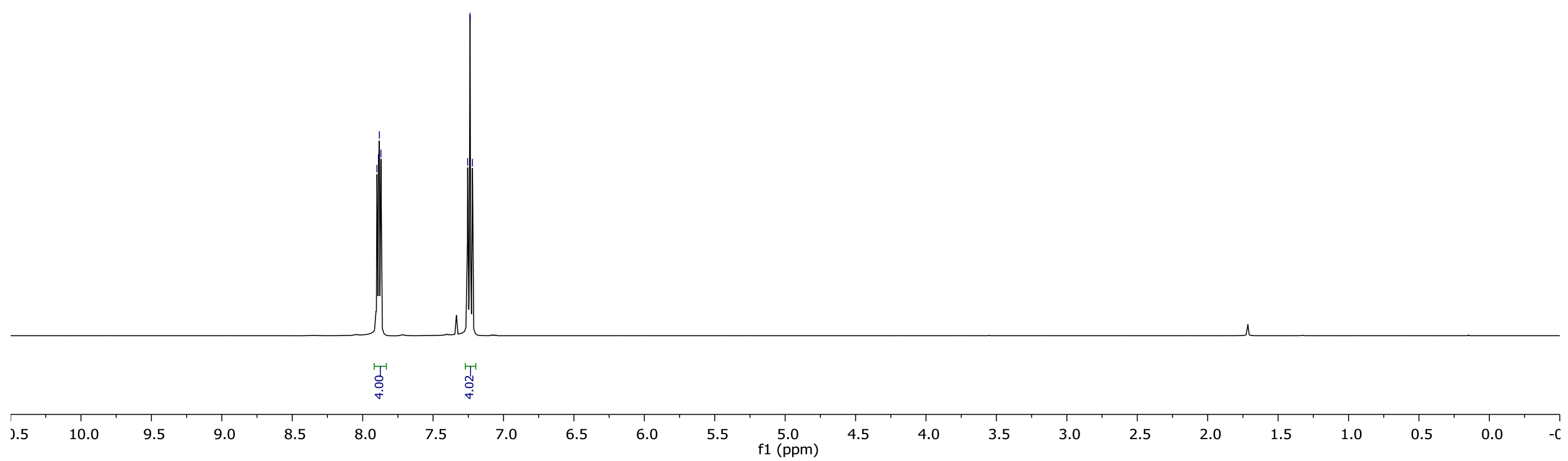


${ }^{13} \mathrm{C}$ NMR of 4,4 '-difluorbenzophenone (S20B)

$\mathrm{CDCl}_{3}, 25^{\circ} \mathrm{C}, 126 \mathrm{~Hz}$

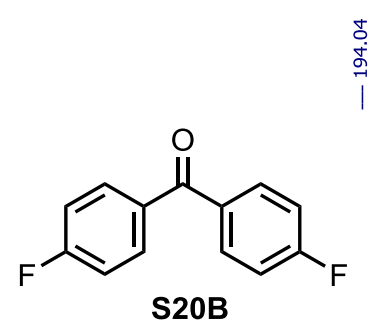

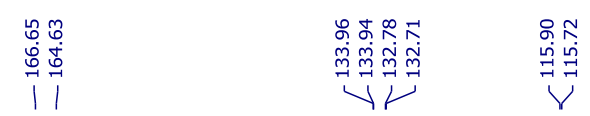

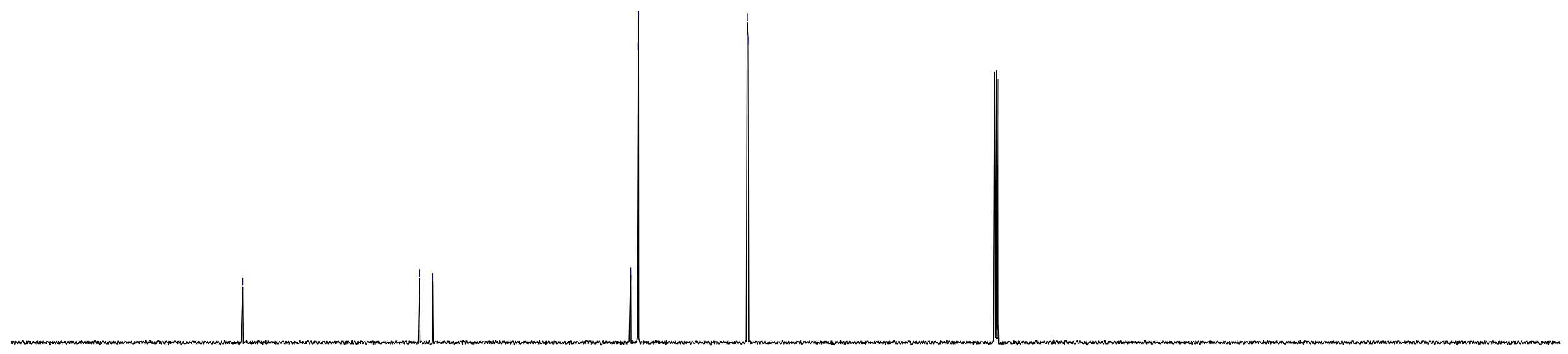

\begin{tabular}{lllllll}
\hline 30 & 220 & 210 & 200 & 190 & 180 & 170
\end{tabular} 
SUPPORTING INFORMATION

$\mathrm{S} 136$

${ }^{19} \mathrm{~F}$ NMR of 4,4'-difluorbenzophenone (S20B)

$\mathrm{CDCl}_{3}, 25^{\circ} \mathrm{C}, 471 \mathrm{MHz}$

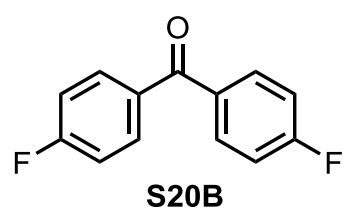

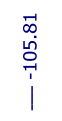

S20B

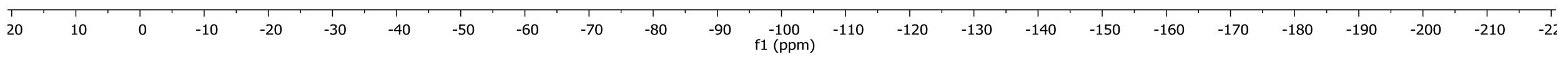


${ }^{1} \mathrm{H}$ NMR of 4-tert-butylbenzaldehyde (S22)

$\mathrm{CDCl}_{3}, 25 \stackrel{\circ}{\mathrm{C}}, 500 \mathrm{MHz}$<smiles>CC(C)(C)c1ccc(C=O)cc1</smiles>

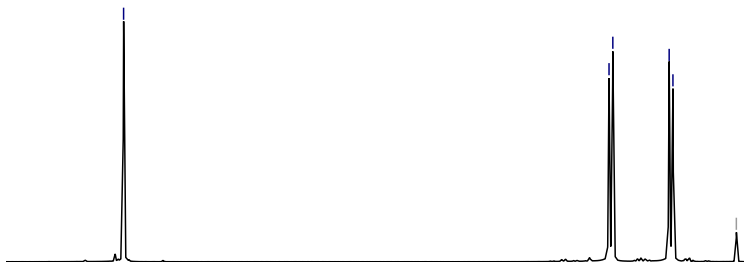


${ }^{13} \mathrm{C}$ NMR of 4-tert-butylbenzaldehyde (S22)

$\mathrm{CDCl}_{3}, 25 \stackrel{\circ}{\circ} \mathrm{C}, 126 \mathrm{~Hz}$

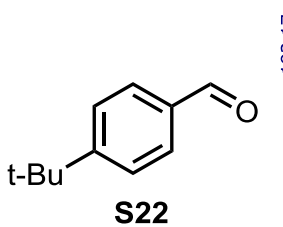


${ }^{1}$ H NMR of 1-(4-bromophenyl) butane-1,2-dimesoxyl (S29)

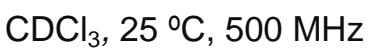
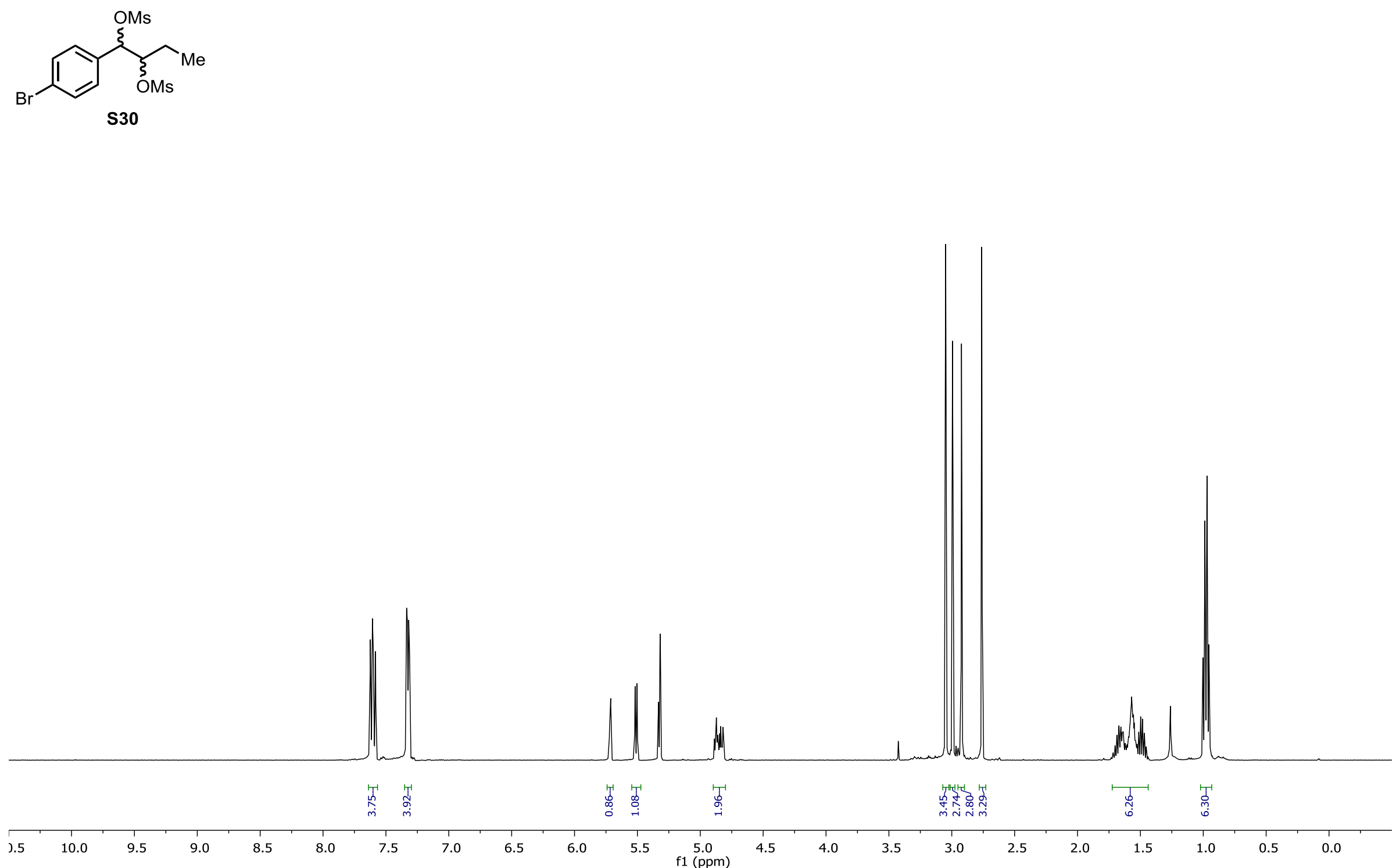
${ }^{13} \mathrm{C}$ NMR of 1-(4-bromophenyl) butane-1,2-dimesoxyl (S29)

$\mathrm{CDCl}_{3}, 25 \stackrel{\circ}{\circ} \mathrm{C}, 126 \mathrm{~Hz}$
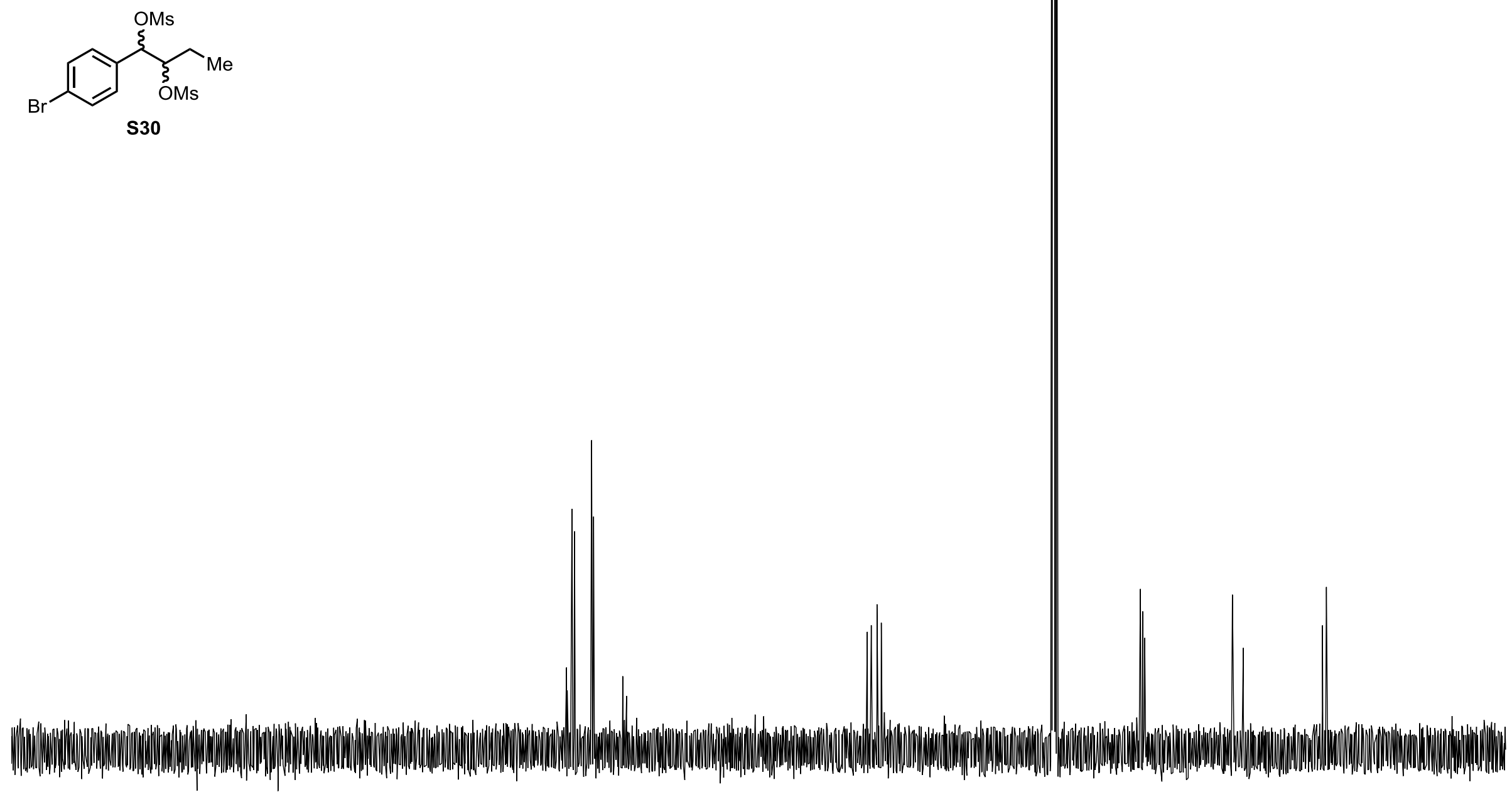